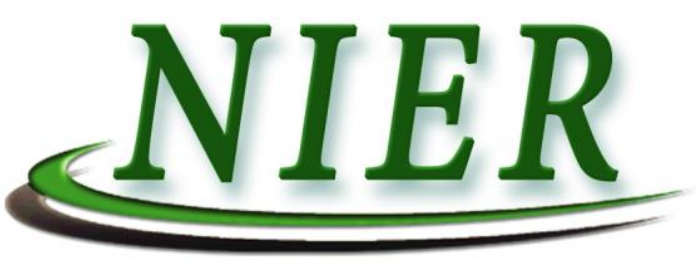

National Institute for Economic Research

\title{
ECONOMY AND SOCIOLOGY
}

THEORETICAL AND SCIENTIFICAL JOURNAL founded in $\mathbf{1 9 5 3}$

No. 2

December 2019

ISSN: 1857-4130

E-ISSN: 2587-3172

Category „B”

https://economy-sociology.ince.md

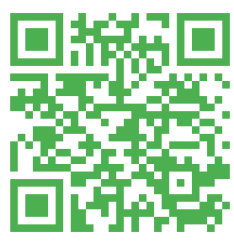

Chisinau, 2019 


\section{EDITORIAL BOARD:}

\section{Editor-in-chief:}

Alexandru STRATAN, Correspondent Member of ASM, Habilitation in economics, Professor, National Institute for Economic Research, Republic of Moldova

Associate Editor-in-chief:

Olga GAGAUZ, Habilitation in sociology, Associate Professor, National Institute for Economic Research, Republic of Moldova

\section{Responsible secretary:}

Iulita BIRCA, Scientific Researcher, National Institute for Economic Research, Republic of Moldova

\section{Members:}

Gheorghe MISCOI, Cor. Mem. of ASM, Free International University, Republic of Moldova

David SMALLBONE, PhD, Professor, Kingston University, Great Britain

Michael GRINGS, PhD, Professor, Martin-Luther Universitatea Halle-Wittenberg, Germany

Luminita CHIVU, PhD, Professor, INCE, România

Vasa LASZLO, PhD, Institute for Foreign Affairs and Trade, Hungary

Thomas RESL, eng., M. Sc., Federal Institute of Agricultural Economics, Austria

Stasys RIMANTAS, PhD, Professor, Klaipeda University, Lithuania

Jamila BOPIEVA, PhD, Director, University of Economics, Finance and International Trade, Kazakhstan

Vilayat VALIYEV, PhD, Institute for Scientific Research oh Economic Reforms, Azerbaijan

Karl William VIEHE, B.A., M.A., J.D., M.L.T., The George Washington University, USA

Tomas KUCERA, PhD, Charles University in of Prague, Czech Republic

Gemma MASAHIKO, PhD, Professor, Waseda University in Tokyo, Japan

Apostolos PAPAPHILIPPOU, PhD, Four Assist Development Consulting, Greece

Euphrasia Susy SUHENDRA, PhD, Professor, Gunadarna University Indonesia

Dimitre NIKOLOV, PhD, Professor, Institute of Agricultural Economics, Bulgaria

Sergei PIROJKOV, Academician, National Academy Ukraine

Svetlana BELOUSOVA, PhD, Professor, International University of Business and Law, Ukraine

Dorina ROSCA, PhD, Ecole des Hautes Études en Sciences Sociales, School of Higher Studies in Social Sciences - Paris, France

Andrzej KOWALSKI, PhD, Professor, Institute of Agricultural and Food Economics, Poland

Emil DINGA, PhD, Professor, Romanian Academy, Romania

Rodica PERCIUN, PhD, Associate Professor, National Institute for Economic Research, Republic of Moldova

Angela TIMUS, PhD, Associate Professor, National Institute for Economic Research, Republic of Moldova

Ludmila MALCOCI, PhD, Institute of Legal, Political and Sociological Research, Republic of Moldova

Victor MOCANU, PhD, Associate Professor, Institute of Legal, Political and Sociological Research, Republic of Moldova

Diana CHEIANU-ANDREI, PhD, Associate Professor, State University of Moldova, Republic of Moldova

\section{LITERARY EDITORS OF EDITORIAL COMPLEX:}

Editor-in-chief: Iulita BIRCA

Editor: Catalina GRAPA

English Editor: Victoria TIMUS

Computerized layout: Valentin BIRCA

Designer: Alexandru SANDULESCU

The journal „Economy and Sociology” is recognized as scientific publication in the field, accredited of „B” category, Decision of the Supreme Council on the Science and Technological Development of Academy of Sciences of Moldova and National Council for Accreditation and Attestation, Decision No. 158 of October 26, 2017.

The journal is indexed in the following international databases:

DOAJ IDEAS, EconPapers, LogEc, SOCIONET, INDEX COPERNICUS, OAJI, RePEc, EZB, IBN, eLIBRARY.RU

CROSSREF - Digital Object Identifier (DOI)

Bibliographic editing: D. Pelepciuc, A. Catana, N. Dalinitchi, Indexer: E. Migunova, S. Neaga

(C) National Institute of Economic Research, Republic of Moldova in collaboration with

Sociology Department of Research Institute of Legal and Political of ASM

The taking over of the texts that are published in the journal „Economy and Sociology” is possible only with the author's agreement. Responsibility for each published text belongs to the authors. The authors declare on their own responsibility that the articles are authentic and there is no conflict of interest and also transmit the copyright to the publisher. Authors' views are not always accordingly with the editorial board's opinion. 


\section{CONTENTS}

\section{ECONOMY}

Dmitri PARMACLI, Habilitation in Economics, Professor, State Comrat University, Republic of Moldova

Alexandru STRATAN, Habilitation in Economics, Professor, National Institute for Economic Research, Republic of Moldova

DETERMINING AGRICULTURE PRODUCTION EFFICIENCY BASED ON NEW ASSESSMENT TOOLS

Kseniia GOROVA, PhD in Economics, Associate Professor, NTU „Kharkiv Polytechnic Institute", Ukraine

Oleksandr DLUHOPOLSKYI, Habilitation in Economics, Professor, Ternopil National Economic University, Ukraine

Tetiana DLUHOPOLSKA, PhD Student, Ternopil National Economic University, Ukraine

ENTERING IN THE GLOBAL MANUFACTURING OUTSOURCING MARKET AND INNOVATIVE DEVELOPMENT OF THE UKRAINIAN INDUSTRIAL ENTERPRISES......

Victoria IORDACHI, PhD in Economics, Associated Researcher, National Institute for Economic Research, Republic of Moldova

Stela CIOBU, PhD in Economics, Associated Professor, Academy of Economic Studies of Moldova

EXTERNAL DEBT IMPLICATIONS ON THE DEVELOPMENT OF NATIONAL ECONOMY.......

Otilia MANTA, PhD in Economics, Center for Financial and Monetary Research, Victor Slavescu Romanian Academy

THE RISK OF FINANCIAL NETWORKS IN THE CONTEXT OF CURRENT CHALLENGES..........

Andrzej JARYNOWSKI, PhD Candidate, Moldova State University, Chisinau, Republic of Moldova, Interdisciplinary Research Institute in Wroclaw, Poland COST-EFFECTIVENESS ANALYSIS FOR HPV MITIGATION STRATEGIES IN THE REPUBLIC OF MOLDOVA BASED ON INFECTIOUS DISEASE MODELLING

\section{SOCIOLOGY}

Stefano AMODIO, PhD in Philosophy, Professor of work psychology, Istitut Teseo, Italy THE PSYCHOLOGICAL CONTRACT IN A GLOBALIZED SOCIETY: NEW CONTRACTUAL AND RELATIONAL FORMS.

Inga CHISTRUGA-SINCHEVICI, PhD in Sociology, National Institute for Economic Research, Republic of Moldova Natalia BARGAN, National Institute for Economic Research, Republic of Moldova THE EXPERIENCE OF WORK-LIFE BALANCE FACED BY MOTHERS WITH PRESCHOOL CHILDREN.

Irina CAUNENCO, PhD in Psychology, Associate Professor, Institute of Cultural Heritage, Republic of Moldova

Lucia GASPER, PhD in Psychology, Senior Researcher, Institute of Legal, Political and Sociological Research, Republic of Moldova

THE SYSTEM OF VALUES AND PERCEPTION OF TIME IN THE TRANSITIONAL SOCIETY: SOCIO-PSYCHOLOGICAL ISSUES AND PERSPECTIVES. 
Tatiana TABAC, PhD Student, National Institute for Economic Research, Republic of Moldova ACQUISITION OF FOREIGN CITIZENSHIP BY MOLDOVAN IMMIGRANTS.

\section{REVIEWS}

REVIEW on the monograph: „FOOD SECURITY MANAGEMENT”

Author: Maria OLEINIUC, PhD in Economics, Associated Professor, Republic of Moldova Reviewer: Dragos CIMPOIES, Habilitation in Economics, Professor, the State Agricultural University of Moldova. 
Dmitri PARMACLI, doctor habilitat în economie, profesor, Universitatea de Stat din Comrat, Republica Moldova

Alexandru STRATAN, doctor habilitat în economie, profesor, Institutul Național de Cercetări Economice, Republica Moldova

DETERMINAREA EFICIENȚEI PRUDUCŢIEI AGRICOLE ÎN BAZA UNOR INSTRUMENTE NOI

DE EVALUARE

Kseniia GOROVA, doctor în economie, conferențiar cercetător, NTU «Institutul Politehnic Kharkiv», Ucraina

Oleksandr DLUHOPOLSKYI, doctor în economie, profesor, Universitatea Economică Națională Ternopil, Ucraina

Tetiana DLUHOPOLSKA, doctorand, Universitatea Națională Economică Ternopil, Ucraina INTRAREA PE PIATA GLOBALĂ DE OUTSOURCING AL PRODUCERII ŞI DEZVOLTAREA INOVAȚIONALĂ A ÎNTREPRINDERILOR INDUSTRIALE DIN UCRAINA

Victoria IORDACHI, doctor în economie, conferențiar cercetător, Institutul Național de Cercetări Economice, Republica Moldova

Stela CIOBU, doctor în economie, conferențiar cercetător, Academia de Studii Economice a Moldovei

IMPLICAȚIILE DATORIEI EXTERNE ASUPRA DEZVOLTĂRII ECONOMIEI NAȚIONALE.........

Otilia MANTA, doctor în economie, Centrul de Cercetare Financiară și Monetară „Victor Slăvescu", Academia Română

RISCUL REȚELELOR FINANCIARE ÎN CONTEXTUL PROVOCĂRILOR ACTUALE

Andrzej JARYNOWSKI, doctorand, Universitatea de Stat din Moldova, Chișinău, Republica Moldova, Institutul Interdisciplinar de Cercetare din Wroclaw, Polonia

ANALIZA COST-EFICACITATE PENTRU STRATEGIILE DE ATENUARE A HPV - MODEL PENTRU REPUBLICA MOLDOVA BAZAT PE MODELAREA BOLILOR INFECTIOASE.

\section{SOCIOLOGIE}

Stefano AMODIO, doctor în filozofie, profesor de psihologie a muncii, Istitutul Teseo, Italia CONTRACTUL PSIHOLOGIC ÎNTR-O SOCIETATE GLOBALIZATĂ: FORME NOI CONTRACTUALE ȘI RELAȚIONALE

Inga CHISTRUGA-SîNCHEVICI, doctor în sociologie, Institutul Național de Cercetări Economice, Republica Moldova

Natalia BARGAN, Institutul Național de Cercetări Economice, Republica Moldova

EXPERIENȚE ALE MAMELOR CU COPII DE VÂRSTA PREȘCOLARĂ ÎN ECHILIBRAREA MUNCII ȘI VIEȚII DE FAMILIE

Irina CAUNENCO, doctor în psihologie, conferențiar cercetător, Institutul Patrioniului Cultural, Republica Moldova

Lucia GAȘPER, doctor în psihologie, Institutul de Cercetări Juridice, Politice și Sociologice, Republica Moldova

ORIENTĂRILE VALORICE ȘI PERCEPȚIA TIMPULUI ÎN SOCIETATEA TRANZITIVĂ: PROBLEME SOCIO-PSIHOLOGICE SI PERSPECTIVE. 
Tatiana TABAC, doctorand, Institutul Național de Cercetări Economice, Republica Moldova DOBÂNDIREA CETĂŢENIEI STRĂINE DE CĂTRE IMIGRANȚII DIN MOLDOVA

\section{RECENZII}

RECENZIE la monografia: „MANAGEMENTUL SECURITĂTII ALIMENTARE"

Autor: Maria OLEINIUC, doctor în economie, Republica Moldova

Recenzent: Dragoș CIMPOIEȘ, doctor habilitat în economie, profesor universitar,

Universitatea Agricolă de Stat din Moldova..

\section{ALTE COMPARTIMENTE}

REGULAMENTUL DE PUBLICARE A ARTICOLELOR ŞTIINŢIFICE ÎN REVISTA „ECONOMIE ŞI SOCIOLOGIE”, CATEGORIA „B” 


\section{СОДЕРЖАНИЕ}

\section{ЭКОНОМИКА}

Дмитрий ПАРМАКЛИ, доктор хабилитат, профессор, Государственный Комратский Университет, Республика Молдова

Александру СТРАТАН, доктор хабилитат, профессор, Национальный Институт Экономических Исследований, Республика Молдова

ОПРЕДЕЛЕНИЕ ЭФФЕКТИВНОСТИ СЕЛЬСКОХОЗЯЙСТВЕННОГО ПРОИЗВОДСТВА НА ОСНОВЕ НОВЫХ ИНСТРУМЕНТОВ ОЦЕНКИ.

Ксения ГОРОВАЯ, кандидат экономических наук, доцент, Национальный технический университет „Харьковский политехнический институт", Украина Александр ДЛУГОПОЛЬСКИЙ, доктор экономических наук, профессор, Тернопольский Национальный Экономический университет, Украина

Татьяна ДЛУГОПОЛЬСКАЯ, аспирант, Тернопольский Национальный Экономический университет, Украина

ВЫХОД НА ГЛОБАЛЬНЫЙ РЫНОК АУТСОРСИНГА ПРОИЗВОДСТВА И ИННОВАЦИОННОЕ РАЗВИТИЕ ПРОМЫШЛЕННЫХ ПРЕДПРИЯТИЙ УКРАИНЫ............

Виктория ИОРДАКИ, кандидат экономических наук, Наџиональный Институт Экономических Исследований, Республика Молдова

Стелла ЧОБУ, кандидат экономических наук, Академия Экономического Образования Молдовы

ВЛИЯНИЕ ВНЕШНЕГО ДОЛГА НА РАЗВИТИЕ НАЦИОНАЛЬНОЙ ЭКОНОМИКИ................

Отилия МАНТА, кандидат экономических наук, Центр финансовых и валютных исследований Виктор Слэвеску, Румынская Академия

РИСК ФИНАНСОВЫХ СЕТЕЙ В КОНТЕКСТЕ СОВРЕМЕННЫХ ВЫЗОВОВ.

Анджей ЯРИНОВСКИЙ, аспирант, Молдавский Государственный Университет в Кишиневе, Республика Молдова, Междисциплинарный научно-исследовательский институт во Вроцлаве, Польша

АНАЛИЗ ЭКОНОМИЧЕСКОЙ ЭФФЕКТИВНОСТИ СТРАТЕГИЙ БОРЬБЫ С ВПЧ В РЕПУБЛИКЕ МОЛДОВА НА ОСНОВЕ МАТЕМАТИЧЕСКОГО МОДЕЛИРОВАНИЯ ИНФЕКЦИОННЫХ ЗАБОЛЕВАНИЙ.

Стефано АМодИо, кандидат философских наук, профессор психологии труда, Институт Тезео, Италия

ПСИХОЛОГИЧЕСКИЙ ДОГОВОР В ГЛОБАЛИЗИРОВАННОМ ОБЩЕСТВЕ: НОВЫЕ ДОГОВОРНЫЕ И РЕЛЯЦИОННЫЕ ФОРМЫ.

Инга КИСТРУГА-СИНКЕВИЧ, Кандидат социологических наук, Национальный Институт Экономических Исследований, Республика Молдова

Наталья БАРГАН, Национальный Институт Экономических Исследований, Республика Молдова

ОПЫТ МАМ С ДЕТЬМИ ДОШКОЛЬНОГО ВОЗРАСТА В БАЛАНСИРОВАНИИ МЕЖДУ РАБОТОЙ И СЕМЬЕЙ 
Ирина КАУНЕНКО, кандидат психологических наук, Институт Культурного Наследия, Республика Молдова

Лучия ГАШПЕР, кандидат психологических наук, Институт Юридических, Политических и Социологических Исследований, Республика Молдова

ЦЕННОСТНЫЕ ОРИЕНТАЦИИ И ВОСПРИЯТИЕ ВРЕМЕНИ В ТРАНЗИТИВНОМ ОБЩЕСТВЕ: СОЦИАЛЬНО ПСИХОЛОГИЧЕСКИЕ ПРОБЛЕМЫ И ПЕРСПЕКТИВЫ............

Татьяна ТАБАК, аспирант, Национальный Институт Экономических Исследований, Республика Молдова

ПОЛУЧЕНИЕ ИНОСТРАННОГО ГРАЖДАНСТВА ИММИГРАНТАМИ ИЗ МОЛДОВЫ.........

\section{РЕЦЕНЗИИ}

РЕЦЕНЗИЯ На МОНОГРафИю: «УПРАВЛЕНИЕ ПРОДОВОЛЬСТВЕННОЙ БЕЗОПАСНОСТЬЮ»

Автор: Мария ОЛЕЙНЮК, кандидат экономических наук Республика Молдова Рецензент: Драгош ЧИМПОЕШ, доктор хабилитат, профбессор, Государственный аграрный университет Молдовы

ДРУГИЕ РАЗДЕЛЫ

ТРЕБОВАНИЯ К НАУЧНЫМ СТАТЬЯМ ДЛЯ ПУБЛИКАЦИИ В ЖУРНАЛЕ «ЭКОНОМИКА И СОЦИОЛОГИЯ», КАТЕГОРИЯ «В» 


\section{ECONOMY}




\title{
DETERMINING AGRICULTURE PRODUCTION EFFICIENCY BASED ON THE NEW ASSESSMENT TOOLS
}

\author{
Dmitri PARMACLI', Habilitation in Economics, Professor, \\ State Comrat University, Republic of Moldova \\ Alexandru STRATAN', Habilitation in Economics, Professor, \\ National Institute for Economic Research, Republic of Moldova
}

\author{
DOI: https://doi.org/10.36004/nier.es.2019.2-01 \\ JEL Classification: M41, I10, L31 \\ UDC: 631.158:005.52
}

\section{ABSTRACT}

Profitability indicators describe the result of the management process more comprehensively than profit, characterize the effectiveness and efficiency of management, because their value shows the ratio of the effect with cash or input resources. They are used to evaluate the performance of the enterprise, as well as an instrument of investment policy and pricing. Most often, in practice, agricultural enterprises calculate indicators that characterize the profitability of production costs, investment projects and profitability of sales. It is very important to calculate the profitability levels of each type of sold products and give them an estimate, which allows identifying the most profitable ones. Methodological approaches are proposed in order to determine the four levels of profitability of the sold products, which are clearly presented in tables and graphs. It is important to grade the levels of profitability for each type of sold product, and therefore, it is becoming possible to assess their degree of effectiveness or level of profitability. The purpose of the article is to provide teachers from higher educational institutions, as well as agricultural specialists with modern tools for assessing the effectiveness of sold products, in particular through application of an unconventional method. The presented study allows specialists of agricultural enterprises to determine on the basis of two coefficients (return on fixed and specific variable costs) the moderate, rational, optimal and high profitability of sold grain, sunflower, grapes and other products and based on them to justify the amount of expected profit.

Keywords: profitability, profit, efficiency, profit margin, rate of return, fixed costs, price, variable costs per unit, cost.

Indicatorii de rentabilitate descriu rezultatul procesului managerial mai cuprinzător decât profitul, caracterizează eficiența și eficacitatea managementului, dat fiind faptul că valoarea acestora prezintă relația dintre efect și resursele de numerar sau cele utilizate. Aceștia sunt utilizați pentru a evalua activitățile întreprinderii, precum și în calitate de instrument al politicii investiționale și de stabilire a prețurilor. În cele mai dese cazuri, în practică, întreprinderile agricole calculează indicatori care caracterizează rentabilitatea costurilor de producție, a proiectelor de investiții și a rentabilității vânzărilor. Este foarte important de a calcula nivelurile de rentabilitate ale fiecărui tip de produse vândute și de a oferi o estimare a acestora, ceea ce va contribui la identificarea celor mai profitabile produse. Sunt propuse abordări metodologice pentru determinarea a patru niveluri de rentabilitate a produselor vândute, care sunt prezentate în mod clar în tabele și grafice. Este important de a evalua nivelurile de rentabilitate pentru fiecare tip de produs vândut, ceea ce permite evaluarea gradului lor de eficiență sau nivelul de rentabilitate. Scopul articolului este de a oferi cadrelor didactice din instituțiile de învățământ superior, precum și specialiștilor din domeniul agrar instrumente moderne pentru evaluarea eficienței produselor vândute, în special prin utilizarea unei metode neconvenționale. Studiul prezentat permite specialiștilor din întreprinderile agricole să determine în baza a doi coeficienți (rentabilitatea costurilor fixe și a costurilor variabile pe unitate) valoarea rentabilității moderate, raționale, optime și ridicate a cerealelor vândute, a florii-soarelui, strugurilor, precum și a altor produse și în baza acestora, să justifice valoarea profitului scontat.

Cuvinte-cheie: rentabilitate, profit, eficiență, marjă de profit, rata de rentabilitate, costuri fixe, preț, costuri variabile pe unitate, cost.

1 (C) Dmitri PARMACLI, $₫$ parmad741@mail.ru

2 @ Alexandru STRATAN, $₫$ alex_stratan@yahoo.com 
Показатели рентабельности описывают результат процесса управления более полно, чем прибыль, характеризуют результативность и эффективность хозяйствования, так как их величина показывает соотношение эффекта с наличными или использованными ресурсами. Их применяют для оценки деятельности предприятия и как инструмент инвестиционной политики и ценообразования. Чаще всего в практике сельскохозяйственных предприятий рассчитывают показатели, характеризующие рентабельность издержек производства, инвестиционных проектов и рентабельность продаж. Очень важно проводить расчеты уровней рентабельности каждого вида реализованной продукции и осуществлять их оценку, что позволяет выявить наиболее доходные из них. В данной статье предлагаются методические подходы по определению четырех уровней рентабельности реализованной продукции, наглядно представленные в таблицах и графиках. Важно проводить градацию уровней рентабельности по каждому виду реализованной продукции, в связи с чем представляется возможность оценивать степень их эффективности или уровень доходности. Цель статьи обеспечить преподавателей высших учебных заведений, а также специалистов сельского хозяйства современным инструментарием оценки эффективности реализованной продукции, в том числе с использованием нетрадиционного метода. Представленное исследование позволяет специалистам сельскохозяйственных предприятий, на базе двух коэффициентов (окупаемости постоянных и удельных переменных затрат) определять величину умеренной, рациональной, оптимальной и высокой рентабельности реализованного зерна, подсолнечника, винограда и другой продукции и на этой основе обосновать объем ожидаемой прибыли.

Ключевые слова: рентабельность, прибыль, эффективность, норма прибыли, норма прибыли, постоянные затраты, цена, переменные затраты на единицу, стоимость.

INTRODUCTION. Profitability indicators describe the outcome of the managerial process more comprehensively than profit because their values present the effect achieved as a function of the required cash or resource inputs. These indicators are applied to assess the farm's performance and as an investment policy and pricing tool. More often than not, agricultural enterprises calculate certain values that describe the profitability of production costs, investment projects and sales. It is very important to calculate and to assess the profitability of each type of sold products in order to identify the most profitable ones.

RESEARCH METHODOLOGY. This research was based on general scientific methods and certain specific approaches - and in particular an abstract-logical approach to substantiate the methodology applied to assess the efficiency of product sales; statistical and economic approach to analyse prevailing production and sales values for core crops in a given agricultural enterprise; graphic method to compare the actual efficiency of the cultivated crops with their graded profitability levels.

LITERATURE REVIEW. State-of-art agricultural science is looking for new ways to improve the efficiency of agricultural production. Of interest in this respect are the works by V.P. Pavlik $[1,2015]$ and by O.G. Szpikuljak and O.A. Materzynska [2, 2014] proposing a new approach for assessment of product efficiency and substantiating the efficiency growth drivers.

Economic literature considers the sustainability of land-use results from diverse perspectives. In particular, A. Rasskazova and R. Zhdanov introduce the concept of economic efficiency of sustainable land use in their publications [3, 2017]; S. Siptits considers the matters of combining the efficiency with sustainable operation of agro-food systems [4, 2017]; I. Romanenko and N. Evdokimova consider the sustainability and efficiency of such territorial distribution of crop production which would ensure a high degree of utilisation of the territory's bioclimatic potential [5, 2017]. Of importance is also the research performed by A.I. Altukhov [6, 2016]. The author of this latter research explores the current approaches to efficiency assessment of land use in agriculture.

The research performed by Moldovan authors and deserving special mention is the work by V. Doga and E. Timofti, who have developed and suggested in their studies their own versions for the economic engine to improve agricultural efficiency based on sustainable land use $[7,2006 ; 8$, 
2009]. Of importance is also the research by L. Todorici and T. Dudoglo, one of them considers the agricultural production sustainability problems $[9,2013]$ and the other assesses the sustainability of soil productivity in Moldova's regions [10, Dudoglo T., 2017].

The purpose of this article is to provide teachers from higher educational institutions, as well as agricultural specialists with modern tools for assessing the effectiveness of sold products, in particular through application of an unconventional method.

RESEARCH RESULTS. It is known that the performance of agricultural production is largely dependent on weather and climate, i.e. the factors which the current science is not able to forecast more or less reliably. No matter how thoroughly and correctly (in methodology terms) agricultural professionals plan their costs of materials and cash investments with due account of accepted production techniques, it is not possible to reliably forecast the expected crop yields and thus the gross output of the cultivated crops. Similar costs may result in high crop cultivation efficiency and sales profitability in good years and in losses in bad years. This instability is characteristic in particular of risky (marginal) farming zones and in particular of the southern zone of the Republic of Moldova [11, PARMACLI D., DUDOGLO T., 2016]. But then, how can one determine production costs, return on investments and other economic values reflecting management quality in the absence of any reasonably substantiated crop productivity data? That is where we apply marginal analysis as the most appropriate tool.

The research suggests that certain production and sales efficiency indicators finding application in agriculture (such as profit per hectare of the area under the crop and per $100 \mathrm{~kg}$ (metric centner) of harvested products; financial safety margin; and operating leverage) can be calculated with rather high reliability without recourse to the data on yield per hectare and gross output of the cultivated crops. It is known that fixed costs per hectare (FC) and variable costs per unit (AVC) are not affected by the yield per hectare. In other words, this specific nature of fixed costs and variable costs per unit will enable us to make the required efficiency calculations. It is important to estimate the expected selling price $(\mathrm{P})$ as objectively as possible as part of the planning process because neither does selling price depend on the output of any given enterprise since agricultural enterprises operate in an environment of free competition [12, PARMACLI D., 2016].

Knowing these three values, we can determine the profitability threshold $\left(\mathrm{q}_{\min }\right)$ for each crop according to the well-known formula:

where:

$$
\mathrm{q}_{\text {min }}=\frac{\mathrm{FC}}{\mathrm{p}-\mathrm{AVC}} \text { metric centners }(100 \mathrm{~kg}) \text { per hectare }
$$

$\mathrm{FC}=$ semi-fixed costs per hectare of the area under the crops, in MDL;

AVC = variable costs per unit of output, in MDL per metric centner $(100 \mathrm{~kg})$;

$\mathrm{P}=$ selling price of the product, in MDL per metric centner $(100 \mathrm{~kg})$.

Our research identified a certain interdependence between the economic efficiency values of the produced and sold products and the difference between the actual crop yield (q) and the breakeven yield (profitability threshold). To reflect this difference, we have introduced an indicator which we call the yield growth rate $(\mathrm{n})$ :

$$
\mathrm{n}=\frac{\mathrm{q}}{q_{\min }}
$$

Below are the formulas used to calculate the value of certain indicators reflecting the efficiency of marketable products in agriculture:

- profit per hectare:

$$
\mathrm{P}=\mathrm{FC}(\mathrm{n}-1) \text {, in MDL per hectare }
$$

- profit per unit - metric centner $(100 \mathrm{~kg})$ of products:

where:

$$
\mathrm{P}=\mathrm{md}\left(1-\frac{1}{\mathrm{n}}\right) \text {, in MDL per metric centner }(100 \mathrm{~kg})
$$

$\mathrm{md}=$ marginal income per product output unit $(\mathrm{md}=\mathrm{p}-\mathrm{AVC})$, in MDL per metric centner $(100 \mathrm{~kg})$ 
- financial safety margin (D):

- operating leverage (L):

$$
\mathrm{D}=1-\frac{1}{n}
$$

$$
\mathrm{L}=\frac{n}{n-1}
$$

Table 1 and Figure 1 below show the interdependence between profit and yield growth rate.

The interdependence between profit and yield growth rate

\begin{tabular}{|c|c|c|c|c|c|}
\hline $\begin{array}{c}\text { Yield growth } \\
\text { rate }\end{array}$ & $\begin{array}{c}\text { Profit per } \\
\text { hectare } \\
\text { growth rate }\end{array}$ & $\begin{array}{c}\text { Profit per } \\
\text { output unit } \\
\text { growth rate }\end{array}$ & $\begin{array}{c}\text { Yield growth } \\
\text { rate }\end{array}$ & $\begin{array}{c}\text { Profit per } \\
\text { hectare } \\
\text { growth rate }\end{array}$ & $\begin{array}{c}\text { Profit per } \\
\text { output unit } \\
\text { growth rate }\end{array}$ \\
\hline 1.0 & 0.0 & 0.000 & 2.6 & 1.6 & 0.616 \\
\hline 1.2 & 0.2 & 0.167 & 2.8 & 1.8 & 0.643 \\
\hline 1.4 & 0.4 & 0.286 & 3.0 & 2.0 & 0.667 \\
\hline 1.6 & 0.6 & 0.375 & 3.2 & 2.2 & 0.688 \\
\hline 1.8 & 0.8 & 0,445 & 3.4 & 2.4 & 0.706 \\
\hline 2.0 & 1.0 & 0.500 & 3.6 & 2,6 & 0.723 \\
\hline 2.2 & 1.2 & 0.546 & 3.8 & 2.8 & 0.737 \\
\hline 2.4 & 1.4 & 0.584 & 4.0 & 3.0 & 0.750 \\
\hline
\end{tabular}

Source: Calculated according to Formulas 3 and 4.

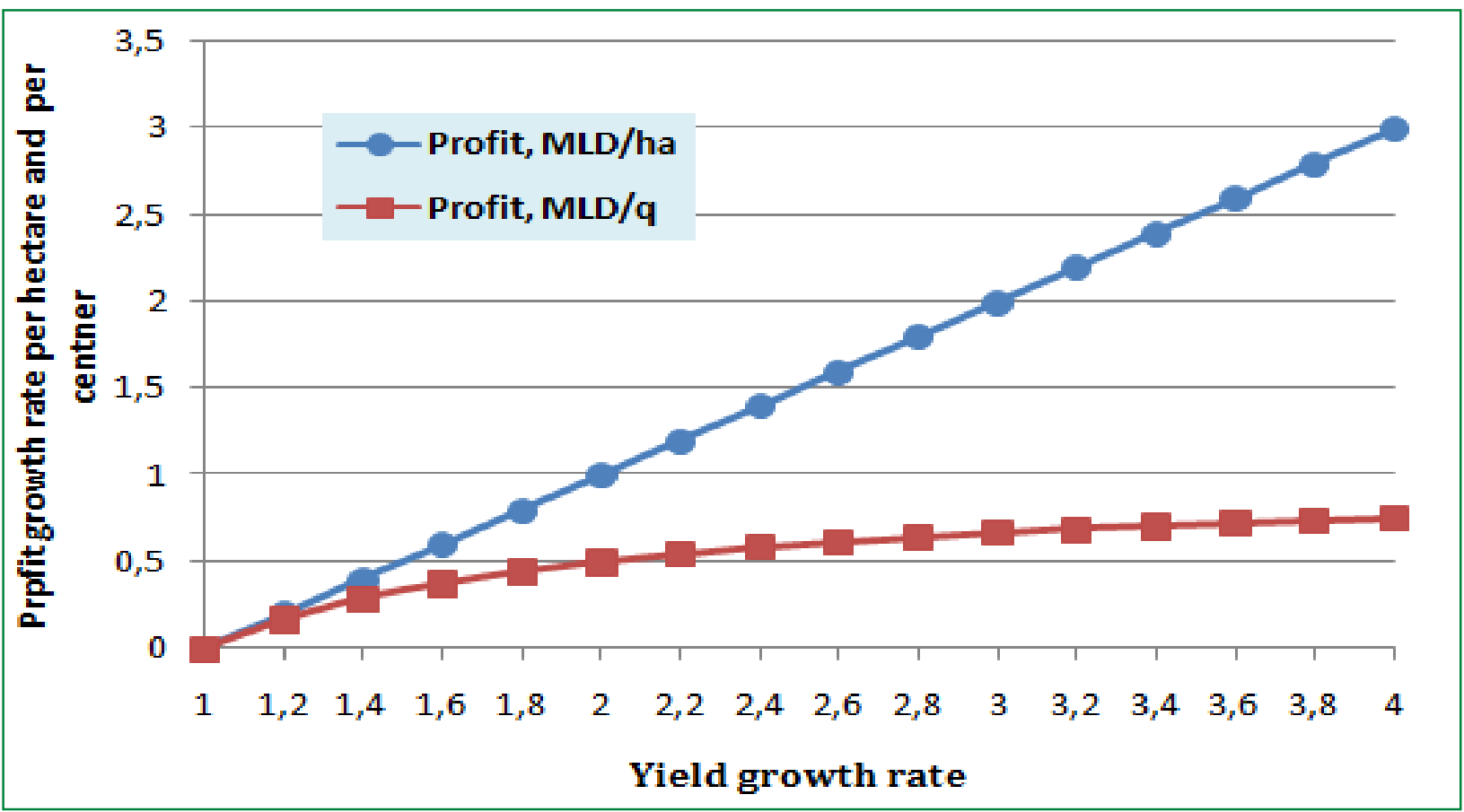

Figure 1. Influence of yield growth rate on profit per hectare growth rate and profit per $100 \mathrm{~kg}$ growth rate

Source: Produced from the data in Table 1.

Now we apply Formulas 5 and 6 to calculate the interdependence between the financial safety margin and the operating leverage on the yield growth rate (Table 2). The financial safety margin increases and the operating leverage decreases with growing yields. However, the graph in Figure 2 shows that the rates of the above changes are slowing down with growing yields. 
Interdependence between the financial safety margin and operating leverage and the yield growth rate

\begin{tabular}{|c|c|c|c|c|c|}
\hline $\begin{array}{c}\text { Yield growth } \\
\text { rate }\end{array}$ & $\begin{array}{c}\text { Financial } \\
\text { safety } \\
\text { margin }\end{array}$ & $\begin{array}{c}\text { Operating } \\
\text { leverage }\end{array}$ & $\begin{array}{c}\text { Yield growth } \\
\text { rate }\end{array}$ & $\begin{array}{c}\text { Financial } \\
\text { safety } \\
\text { margin }\end{array}$ & $\begin{array}{c}\text { Operating } \\
\text { leverage }\end{array}$ \\
\hline 1.0 & 0.000 & 0.00 & 2.6 & 0.616 & 1.62 \\
\hline 1.2 & 0.167 & 5.99 & 2.8 & 0.643 & 1.56 \\
\hline 1.4 & 0.286 & 3.50 & 3.0 & 0.667 & 1.50 \\
\hline 1.6 & 0.375 & 2.67 & 3.2 & 0.688 & 1.45 \\
\hline 1.8 & 0.445 & 2.25 & 3.4 & 0.706 & 1.42 \\
\hline 2.0 & 0.500 & 2.00 & 3.6 & 0.723 & 1.38 \\
\hline 2.2 & 0.546 & 1.83 & 3.8 & 0.737 & 1.36 \\
\hline 2.4 & 0.584 & 1.71 & 4.0 & 0.750 & 1.33 \\
\hline
\end{tabular}

Source: Calculated according to Formulas 5 and 6.

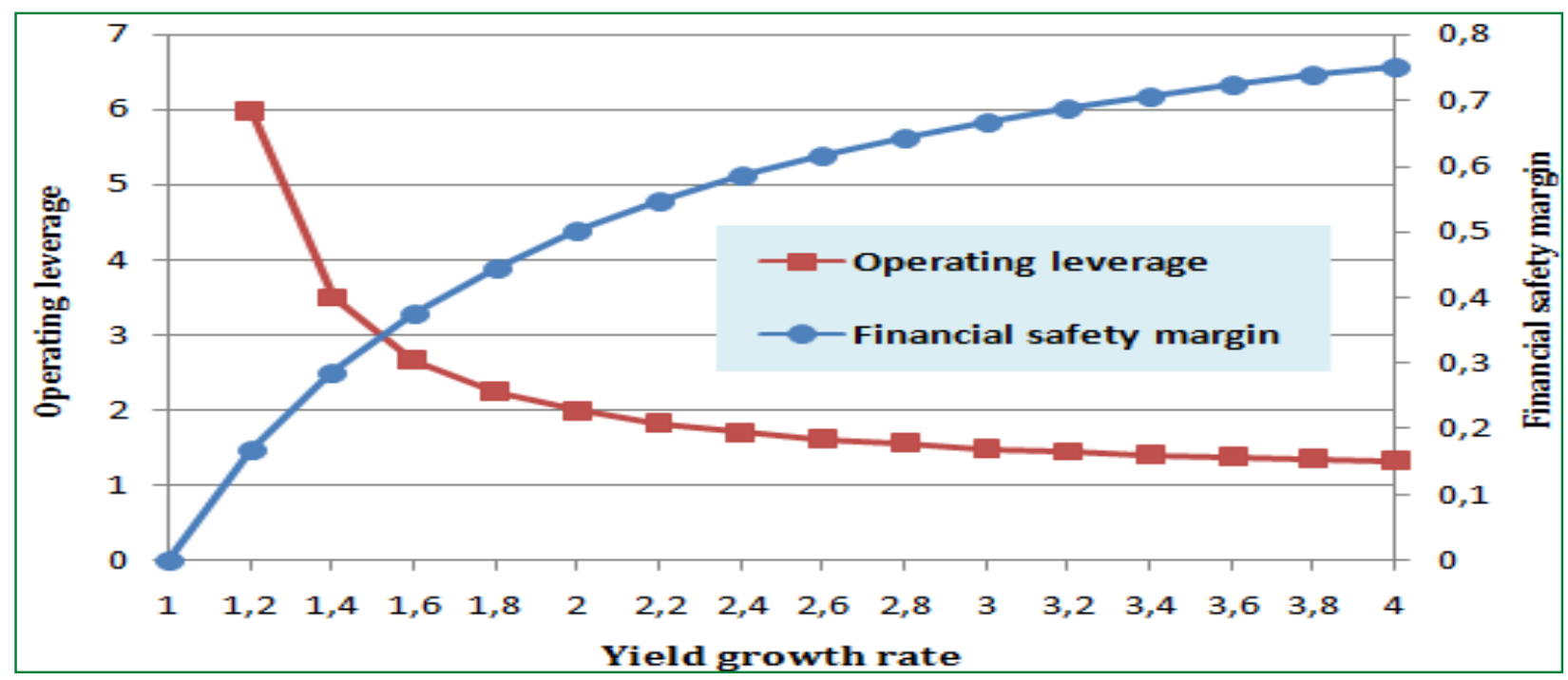

Figure 2. Interdependence between the financial safety margin and operating leverage and the yield growth rate

Source: Produced from the data in Table 2.

It is known that any agricultural enterprise usually cultivates more than one crop. The production and sale of some crops gives a high return on investments while some other crops have a low profit margin. Nevertheless, it is not always possible to discontinue production of these latter crops because of agro-technical crop rotation requirements or some other in-house and external reasons. In other words, sales of different products invariably have different profit margins. The profitability of a particular crop can fluctuate significantly in the Republic of Moldova, mainly because of the weather and climatic conditions prevailing during the crop cultivation and harvesting season, and range between loss and a profit margin of over $30 \%$. For example, the profit margin of grain sold in the Republic of Moldova fluctuated between $-3.5 \%$ in 2009 and $+39.9 \%$ in 2011; of sunflower seeds - between $16.6 \%$ in 2009 and $89.8 \%$ in 2010; of grapes - between $6.0 \%$ in 2009 and $37.0 \%$ in 2012 [13, 2018]. Therefore, a scientifically substantiated classification (gradation) of the sales profitability levels for diverse agricultural crops will be in demand because each level will indicate a particular efficiency range for cultivation of the crop concerned. It is important for an agricultural enterprise to know and thus to objectively budget the level of costs that will ensure a certain yield per hectare required to achieve sustainable and/or expanding reproduction. Thus, we have approached the problem of a substantiated profitability planning for each of the crops cultivated by the enterprise. 
Of course, the objective of any business entity is to ensure higher return on its production inputs. Nevertheless, for diverse reasons, the average 2001-2012 profit margins in agricultural enterprises in the southern zone of the Republic of Moldova for production and sales were: $43.8 \%$ for sunflower seeds, $46.0 \%$ for winter rape, $26.7 \%$ for grapes, $11.7 \%$ for legumes and grains other than corn, and 6.1\% for corn [13, 2018]. (Starting in 2013, Moldova has no longer published any data concerning the local production costs and so it is not possible to calculate the profit margins).

The profit margin is calculated for sales according to this formula:

$$
\mathrm{P}=\frac{\mathrm{N}-\mathrm{Z}}{\mathrm{Z}}=\frac{\Pi}{\mathrm{Z}}
$$

where:

$\mathrm{P}=$ profit from sales, in MDL;

$\mathrm{Z}=$ costs of production and sales, in MDL.

Thus, it has been demonstrated that the most important efficiency indicator of the product sales can be measured applying a relative value - the profit margin. In view of this measurement nature, it would be perfectly logical to ask this question: if profitability is relative in its nature, why not measure it applying some other relative indicators?

Marginal analysis is used for practical purposes, when planning the revenue from sales of products and the profit margin. Application of this method in financial management of local enterprises will enable more effective management of financial results. However, this is only possible where enterprise planning and cost accounting is organised according to the direct costing approach, i.e. where all costs are subdivided into fixed costs and variable costs.

Studies have demonstrated that the profit margin of sold products can be calculated after this formula [14, Parmacli D., Todorovici L., 2017]:

where:

$$
\mathrm{R}=\frac{\mathrm{p}-\mathrm{AVC}}{\mathrm{p}}+\mathrm{AVC}
$$

$\mathrm{p}=$ selling price, in MDL per $100 \mathrm{~kg}$ (metric centner);

$\mathrm{AVC}=$ variable costs per unit, in MDL per $100 \mathrm{~kg}$ (metric centner);

$\mathrm{f}=$ rate of return on fixed costs (i.e. profit divided by fixed costs)

If we assume that the selling price of products (p) divided by variable costs per unit (AVC) is $\mathrm{k}=\frac{\mathrm{p}}{\mathrm{AVC}}$ (return on variable costs per unit), then:

$$
\mathrm{R}=\frac{\mathrm{K}-1}{\frac{\mathrm{K}}{f}+1}
$$

The experience of agricultural enterprises in the southern zone of the Republic of Moldova has confirmed that profit per hectare of area under the crop should be not lower than fixed costs for sustainable reproduction (we will call this profitability level sustainable) and higher than fixed costs for expanding reproduction (a feasible profitability level). The optimal profitability level is the sales profitability level where profit is three-fold of fixed costs. In case of a high profitability level, profit is four-fold of fixed costs. The calculation formulas for the four profitability levels and the expected result are presented in Table 3.

Table 3

Sales profitability levels

\begin{tabular}{|l|c|c|c|}
\hline \multicolumn{1}{|c|}{$\begin{array}{c}\text { Profitability } \\
\text { level }\end{array}$} & $\begin{array}{c}\text { Profitability level } \\
\text { symbol }\end{array}$ & $\begin{array}{c}\text { Profit level } \\
\text { formula }\end{array}$ & $\begin{array}{c}\text { Expected result } \\
\text { (profit) }\end{array}$ \\
\hline Sustainable & $\mathrm{R}_{\text {sus }}$ & $\mathrm{R}_{\text {sus }}=\frac{\mathrm{K}-1}{\mathrm{~K}+1}$ & $\mathrm{P}=\mathrm{FC}$ \\
\hline Feasible & $\mathrm{R}_{\text {feas }}$ & $\mathrm{R}_{\text {feas }}=\frac{\mathrm{K}-1}{0,5 \kappa+1}$ & $\mathrm{P}=2 \mathrm{FC}$ \\
\hline Optimal & $\mathrm{R}_{\text {opt }}$ & $\mathrm{R}_{\text {opt }}=\frac{\mathrm{K}-1}{0,333 \mathrm{~K}+1}$ & $\mathrm{P}=3 \mathrm{FC}$ \\
\hline High & $\mathrm{R}_{\text {high }}$ & $\mathrm{R}_{\text {high }}=\frac{\mathrm{K}-1}{0,25 \mathrm{~K}+1}$ & $\mathrm{P}=4 \mathrm{FC}$ \\
\hline
\end{tabular}

Source: Table produced by the authors. 
Let us examine the calculations of these profitability levels for 2018 in Daalar Duzu SRL, an agricultural enterprise operating in Ceadir Lunga region, Republic of Moldova. The source data is presented in Table 4. (The standard rules for classification of costs into fixed costs and variable costs were developed by the Economic Research Institute [15, BAJURA, T., STRATAN, A. et al., 2018]). Table 5 shows the above-described profitability levels calculated for the said enterprise. It can be concluded from the table that the sustainable profitability level of wheat sales is in the range of 0 to 0.097 ; the feasible profitability level is in the range of 0.097 to 0.133 ; the optimal profitability level is in the range between 0.133 and 0.154 and the high profitability level is in the range between 0.154 and 0.166 and higher. A similar calculation can be made for other types of products.

It is important to point out that the profit margin growth rate slows down as each next (higher) profitability level (i.e. feasible, optimal, high) is reached. Thus, if the ratio between the feasible profitability and the sustainable profitability is 1.618 for wheat sales, the ratio between the optimal profitability and the feasible profitability is only 1.258 and the ratio between the high profitability and the optimal profitability is 1.150. A similar pattern can be identified for other crops.

2018 production and sales of the core crops in Daalar Duzu SRL

\begin{tabular}{|l|c|c|c|c|c|}
\hline \multicolumn{1}{|c|}{ Indicator } & Wheat & Peas & Corn & Sunflowers & $\begin{array}{c}\text { Soy } \\
\text { beans }\end{array}$ \\
\hline Selling price (p), MDL per 100 kg & 230.60 & 287.10 & 273.60 & 706.20 & 562.90 \\
\hline Fixed costs (FC), MDL per hectare & 1124.00 & 354.00 & 1235.00 & 958.00 & 319.00 \\
\hline $\begin{array}{l}\text { Variable costs per unit (AVC), } \\
\text { MDL per 100 kg }\end{array}$ & 189.66 & 176.13 & 187.96 & 326.04 & 192.57 \\
\hline Total costs (z), MDL per 100 kg & 219.00 & 202.0. & 216.60 & 373.50 & 220.80 \\
\hline Rate of return (K) & 1.216 & 1.630 & 1.456 & 2.166 & 2.924 \\
\hline
\end{tabular}

Source: Form 7-APK and Form 9-APK reports of Daalar Duzu SRL for 2018.

It should also be pointed out that each type of product has its own set of sustainable or other profitability levels. The reason is different fixed costs and variable costs per unit. For example, the ratio between the rates of return on fixed costs and on variable costs per unit is 2.40 in the production of soy beans and wheat - whereas the ratio between the profit margins for a sustainable, feasible, optimal and high profitability level is respectively: 5.05; 5.87; 6.33 and 6.69 . Thus, their profitability growth rates increase at each next (higher) sales efficiency level.

It should be noted that a full break-even on fixed costs is observed at the profit margin of $9.7 \%$ for sales of wheat; $18.6 \%$ for corn; $24.0 \%$ for peas; as high as $36.8 \%$ for sunflower seeds; and $49.0 \%$ for soy beans. Consequently, it is not possible to assess the efficiency of sales, applying the same profitability levels for grain, sunflower seeds, grapes and other products. Different profitability levels should be determined (graded) for each type of sold products in order to assess their efficiency or profitability. This can be done applying the methodology proposed in the foregoing in order to determine their sustainable, feasible, optimal and high profitability levels.

Table 5

Profit margin levels determined for products sold by Daalar Duzu SRL in 2018

\begin{tabular}{|l|c|c|c|c|c|}
\hline \multirow{2}{*}{ Profitability level } & \multicolumn{5}{c|}{ Calculated profit margins for } \\
\cline { 2 - 6 } & Wheat & Peas & Corn & Sunflower seeds & Soy beans \\
\hline Sustainable $\left(\mathrm{R}_{\text {sus }}\right)$ & 0.097 & 0.240 & 0,186 & 0.368 & 0.490 \\
\hline Feasible $\left(\mathrm{R}_{\text {feas }}\right)$ & 0.133 & 0,347 & 0.264 & 0.560 & 781 \\
\hline Optimal $\left(\mathrm{R}_{\text {opt }}\right)$ & 0.154 & 0.409 & 0.307 & 0.678 & 0.975 \\
\hline High $\left(\mathrm{R}_{\text {high }}\right)$ & 0.166 & 0.447 & 0.334 & 0.756 & 1.111 \\
\hline Actual $\left(\mathrm{R}_{\text {fact }}\right)$ & 0.053 & 0.421 & 0.265 & 0.891 & 1,549 \\
\hline Profitability assessment & sustainable & optimal & feasible & high & high \\
\hline
\end{tabular}

Source: Table produced by the authors. 
Analysing the actual profitability values of the product sales (Table 3), it can be noted that wheat production and sale has the lowest efficiency value assessed as sustainable (the actual profitability of 0.053 is below the sustainable profitability level of 0.097 ). The efficiency can be assessed as feasible in case of corn sales, as optimal for sales of peas, and as high for sales of sunflower seeds and soy beans.

How is the aggregate efficiency assessed for all crop sales in the farm? To answer this question, it is necessary to make calculations applying the methodology presented in Table 6. It is very easy and convenient in application. The rate of return on fixed costs for all crops is 2.97 and we can thus assess the aggregate efficiency of product sales as feasible.

The methodology for calculation of the aggregate efficiency of all crop

Table 6 sales in Daalar Duzu SRL in 2018

\begin{tabular}{|c|c|c|c|c|c|c|}
\hline \multirow[b]{2}{*}{ Crop } & \multirow[b]{2}{*}{$\begin{array}{c}\text { Area, } \\
\text { ha }\end{array}$} & \multicolumn{2}{|c|}{ Profit } & \multicolumn{2}{|c|}{ Fixed costs } & \multirow{2}{*}{$\begin{array}{l}\text { Rate of } \\
\text { return on } \\
\text { fixed costs }\end{array}$} \\
\hline & & $\begin{array}{c}\text { Total, } \\
\text { MDL thous. }\end{array}$ & $\begin{array}{l}\text { MDL per } \\
\text { hectare }\end{array}$ & $\begin{array}{l}\text { MDL per } \\
\text { hectare }\end{array}$ & $\begin{array}{c}\text { Total, } \\
\text { MDL thous. }\end{array}$ & \\
\hline Wheat & 629 & 280 & 445 & 1125 & 707.40 & 0.40 \\
\hline Peas & 194 & 226 & 1165 & 354 & 68.70 & 3.29 \\
\hline Corn & 535 & 1319 & 2465 & 1235 & 660.70 & 2.00 \\
\hline Sunflower seeds & 526 & 3537 & 6724 & 958 & 503.90 & 7.02 \\
\hline Soy beans & 137 & 530 & 3869 & 319 & 43.70 & 12.13 \\
\hline Total & 2021 & 5892 & 2915 & 982 & 1984.40 & 2.97 \\
\hline
\end{tabular}

Source: Form 7-APK and Form 9-APK reports of Daalar Duzu SRL for 2018.

By way of illustration, we present the actual data on the 2018 profitability of product sales in Daalar Duzu SRL and assessment thereof in Figure 3 and the extent to which the actual profitability of their sales exceeded (fell short of) the high profitability level in Figure 4.

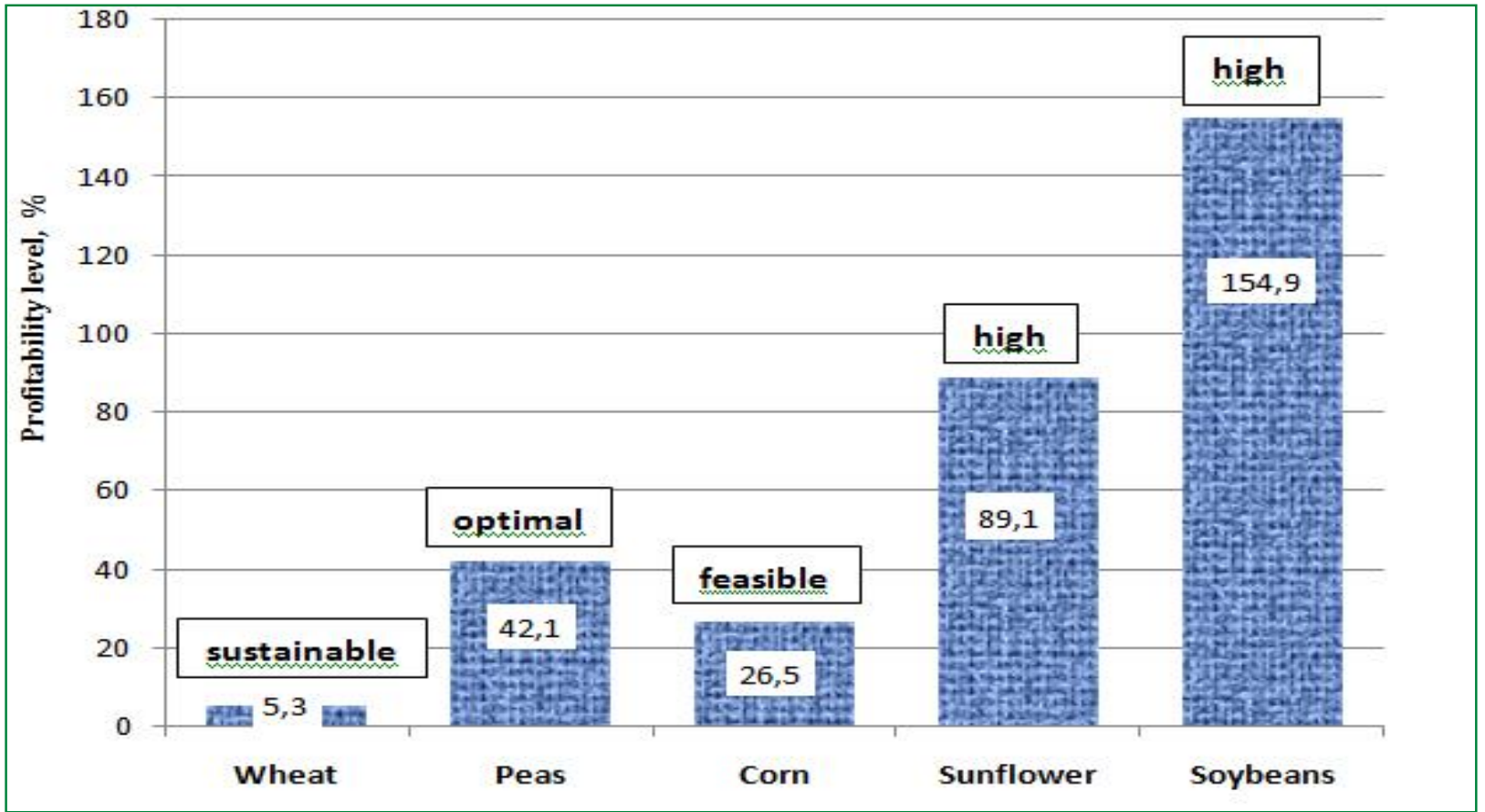

Figure 3. Actual profitability of 2018 product sales in Daalar Duzu SRL and assessment thereof

Source: Produced on the basis of Table 5. 


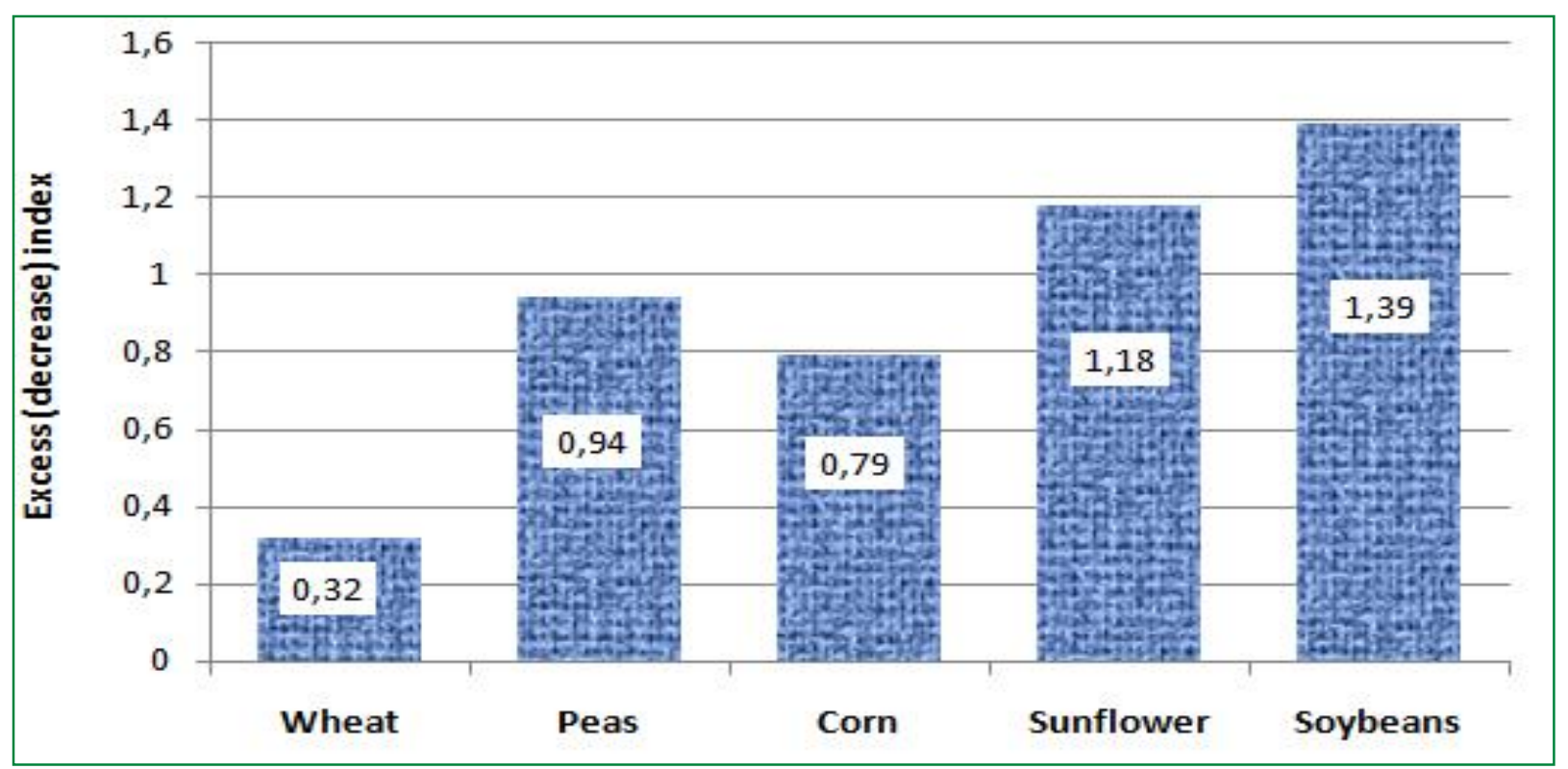

Figure 4. The extent to which the actual sales profitability exceeded (fell short of) the high profitability level in Daalar Duzu SRL in 2018

Source: Produced on the basis of Table 5.

\section{CONCLUSIONS}

The studies have shown that the moderate profitability of products ensures simple reproduction, in which the profit per hectare of sowing should not be lower than the value of fixed costs. Enhanced reproduction is provided by three types of profitability: within a rational one, the profit from product sales should exceed 2 times the value of fixed costs. The optimal level should be considered the level of profitability of the products sold, at which the profit is 3 times more than fixed costs. In case of high profitability, profit is 4 times higher than fixed costs. It is important that the functional relationship between the payback coefficient of fixed costs and the profitability ratio of products sold is represented by a simple formula, which greatly simplifies the task of researchers.

It should be noted as well that the foregoing will enable agricultural professionals operating with two rates of return (on fixed costs and on variable costs per unit) to determine the sustainable, feasible, optimal and high profitability levels for their sales of grain, sunflower seeds, grapes and other products and to substantiate the expected profit amount on the basis thereof.

\section{REFERENCES}

1. PABLIK, V.P. Problemi efektivnogo upravlinnâ sil'skogospodarskimi pidpriestvami. V: Ekonomika APK. 2015, № 11, ss. 85-88. н ISSN 2413-2322; ISSN 2221-1055. [Accesat 23.09.2019]. Disponibil: http://eapk.org.ua/sites/default/files/eapk/2015/11/13.pdf

2. ŠPIKULÂK, O.G., MATERINS'KA, O.A., MAZUR, G.F. Efektivnist' virobnictva zerna sil'skogospodars'kimi pidpriemstvami: teoretiko-metodologičnij aspekt. B: Ekonomika APK. 2014, № 12, ss. 42-49. ISSN 2413-2322; ISSN 2221-1055. [Accesat 23.09.2019]. Disponibil: http://eapk.org.ua/sites/default/files/eapk/14_12_42-49.pdf

3. RASSKAZOVA, A., ŽDANOVA, R. Osnovnye ponâtiâ èkonomičeskoj èffektivnosti upravleniâ ustojčivym zemlepol'zovaniem. V: Meždunarodnyj sel'skohozâjstvennyj žurnal. 2017, №1 2017, ss. 23-25. ISSN 2587-6740.

4. SIPTIC, S. Metody proektirovaniâ èffektivnyh i ustojčivyh variantov razmeŝeniâ sel'skohozâjstvennogo proizvodstva. V: Meždunarodnyj sel'skohozâjstvennyj žurnal. 2017, № 6, ss. 56-59. ISSN 2587-6740.

5. ROMANENKO, I.A., EVDOKIMOVA, N.E. Cenologičeskij podhod pri analize ustojčivosti razmeŝeniâ sel'skogo hozâjstva po regionam России. V: Meždunarodnyj sel'skohozâjstvennyj žurnal. 2017, № 6, ss. 60-63. ISSN 2587-6740. 
6. ALTUHOV, A.I. Soveršenstvovanie organizacionno-èkonomičeskogo mehanizma ustojčivogo razvitiâ agropromyšlennogo proizvodstva. V: Èkonomika sel'skoho-zâjstvennyh i pererabatyvaûŝih predpriâtij. 2016, №7, ss. 2-11. ISSN 0235-2494.

7. Hotărîrea Guvernului cu privire la aprobarea Strategiei de dezvoltare a sectorului agroalimentar în perioada anilor 2006-2015: nr. 1199 din 17.10.2006. In: Monitorul Oficial al Republicii Moldova. 2006, nr. 170-173, art. 1312. [Accesat 23.09.2019]. Disponibil: http://lex.justice.md/index.php?action=view\&view=doc\&lang=1\&id=318200

8. TIMOFTI, E., POPA, D. Eficienţa mecanismului economic în sectorul agrar: monografie. Chişinău: Complexul Editorial al IEFS, 2009. 343 p. ISBN 978-9975-9823-3-7.

9. PARMAKLI, D., TODORIČ, L. Problemy èkonomičeskoj ustojčivosti sel'skoho-zâjstvennyh predpriâtij Respubliki Moldova: monografiâ. Komrat: Tipogr. "Centrografic, 2013. 207 c. ISBN 9975-9751-8-6.

10. DUDOGLO, T.D. Uprevlenie zemel'nym potencialom regiona: voprosy teorii, metodiki, praktiki: monografiâ. Komrat: Tipogr. "Centrografic, 2017. 167 c. ISBN 978-9975-3132-3-0.

11. PARMAKLI, D.M., DUDOGLO, T.D. Urožajnost' i pribyl': metodologičeskie aspekty. In: Creșterea Economică în Condițiile Globalizării = Economic Growth in conditions of globalization: international conference on theoretical and applied economic practices, october 13-14 2016. 11-th edition. Chișinău, 2016, vol. 1, pp. 282-286. ISBN 978-9975-4185-9-9.

12. PARMAKLI, D.M. Metodika gradacii urovnej urožajnosti i zon èffektivnosti produkcii rastenievodstva. V: APK: èkonomika, upravlenie. 2016, №3, ss. 86-91. ISSN 0235-2443.

13. Anuarul Statistic al Republicii Moldova $=$ Statističeskij ežegodnik Respubliki Moldova = Statistical Yearbook of the Republic of Moldova 2018. Chișinău, 2018. 465 p. ISBN 978-997553-418-5.

14. PARMAKLI, D.M., TODORIČ, L.P. i dr. Produktivnost' zemli v sel'skom hozâjstve: èkonomičeskaâ teoriâ i hozâjstvennaâ praktika: monografiâ. Komratskij Gosudarstvennyj universitet, Naučno-issledovatel'skij centr «Progress». Komrat: Tipografia "Centrografic, 2017. 242 p. ISBN 978-9975-3132-7-8.

15. BAJURA, T., STRATAN, A. et al. Tarife de costuri în agricultură: Ghid practice. Chișinău: INCE, 2018. 164 p. ISBN 978-9975-3202-5-2.

\section{ARTICLE HISTORY}

Received 12 November 2019

Accepted 28 November 2019 


\title{
ENTERING IN THE GLOBAL MANUFACTURING OUTSOURCING MARKET AND INNOVATIVE DEVELOPMENT OF THE UKRAINIAN INDUSTRIAL ENTERPRISES
}

\author{
Kseniia GOROVA1, PhD in Economics, Associate Professor, \\ NTU „Kharkiv Polytechnic Institute”, Ukraine \\ Oleksandr DLUHOPOLSKYI², Habilitation in Economics, Professor, \\ Ternopil National Economic University, Ukraine \\ Tetiana DLUHOPOLSKA ${ }^{3}$, PhD Student, \\ Ternopil National Economic University, Ukraine
}

DOI: https://doi.org/10.36004/nier.es.2019.2-02

JEL Classification: D29, F02, F23, 032

UDC: 005.591.6(477)

\section{ABSTRACT}

The urgency of the research is caused by the problem of innovative development that is acutely facing the Ukrainian industrial enterprises. According to statistics, a rather small share of industrial enterprises innovates in their activities and produces innovative products caused by the lack of investment and experience to intensify innovation. Therefore, enterprises should use modern forms of business organization such as outsourcing that has proved itself as a strategic partnership form and a mechanism for the transfer of innovation. The purpose of the research is to develop recommendations for the release of the Ukrainian industrial enterprises to the global manufacturing outsourcing market to ensure their innovative development. The subjects of the study are the types of manufacturing outsourcing and the mechanism of their impact on the innovative development of enterprises. This article is based on the research results of the Ukrainian and foreign scientists, the information on analytical reports, official statistics and public companies' information. The methods used in the research are analysis and synthesis, theoretical generalization, statistical analysis. The article analyzes the position of Ukraine in the global manufacturing outsourcing market. The prospects of the Ukrainian industrial enterprises to enter the global market of industrial outsourcing have been determined. Recommendations on the choice of type of industrial outsourcing have been developed. The results of the research can be used in the practical activity of industrial enterprises and in further researches in the field of innovation management and enterprise organization.

Keywords: manufacturing outsourcing, industry, enterprise, innovative development, innovation, market.

Relevanța studiului se datorează problemei dezvoltării inovaționale, care este deosebit de acută pentru întreprinderile industriale ucrainene. Conform statisticilor ucrainene, o pondere destul de mică a întreprinderilor industriale introduce inovații în activitățile lor și produce produse inovatoare, din cauza lipsei investițiilor și a experienței pentru intensificarea inovației. Prin urmare, întreprinderile sunt obligate să folosească forme moderne de organizare a afacerilor, de exemplu, externalizarea, care s-a stabilit ca o formă eficientă de parteneriat strategic și un mecanism de transfer al inovației. Scopul cercetării este să elaboreze recomandări privind intrarea întreprinderilor industriale ucrainene pe piaţa mondială de externalizare a producției pentru a asigura dezvoltarea lor inovatoare. Obiectul cercetării îl constituie tipurile de externalizare a producției și mecanismul influenței acestora asupra dezvoltării inovatoare a întreprinderilor. Articolul se bazează pe rezultatele studiilor realizate de cercetători ucraineni și străini, informații din rapoarte analitice, statistici oficiale și informații de la companii publice. Metodele de cercetare utilizate în această lucrare includ analiza și sinteza, generalizarea teoretică și analiza statistică. Articolul analizează poziția Ucrainei pe piața globală de externalizare a producției. Sunt determinate perspectivele întreprinderilor industriale ucrainene de a intra pe piața globală de externalizare industrială. Sunt elaborate recomandări privind selectarea tipurilor de externalizare industrială. Rezultatele cercetării pot fi utilizate în activitățile practice ale întreprinderilor industriale și în cercetarea ulterioară în domeniul managementului inovației și organizarea afacerilor.

Cuvinte-cheie: externalizarea producției, industrie, întreprindere, dezvoltare inovatoare, inovație, piață.

1 C Kseniia GOROVA, $\$ ksenya.gf@gmail.com

2 (C) Oleksandr DLUHOPOLSKYI, dlugopolsky77@gmail.com

3 (C) Tetiana DLUHOPOLSKA, tetianadluhopolska@gmail.com

No. 2 / 2019 
Актуальность исследования обусловлена проблемой инновационного развития, которая особенно остро стоит перед украинскими промышленными предприятиями. Согласно украинской статистике, довольно небольшая доля промышленных предприятий внедряет инновации в свою деятельность и производит инновационные продукты, что обусловлено отсутствием инвестиций и опыта для интенсификации инноваций. Поэтому предприятия вынуждены использовать современные формы организации бизнеса, например, аутсорсинг, который зарекомендовал себя эффективной формой стратегического партнерства и механизмом передачи инноваций. Целью статьи является разработка рекомендаций по выходу украинских промышленных предприятий на мировой рынок производственного аутсорсинга для обеспечения их инновационного развития. Предметом исследования являются виды производственного аутсорсинга и механизм их влияния на инновационное развитие предприятий. Статья основана на результатах исследований украинских и зарубежных ученых, информации аналитических отчетов, официальной статистике и информации от публичных компаний. Методы исследования, использованные в работе, включают анализ и синтез, теоретическое обобщение, статистический анализ. В статье анализируется положение Украины на мировом рынке производственного аутсорсинга. Определены перспективы выхода украинских промышленных предприятий на мировой рынок промышленного аутсорсинга. Разработаны рекомендации по выбору типов промышленного аутсорсинга. Результаты исследования могут быть использованы в практической деятельности промышленных предприятий, а также для дальнейших исследований в области управления инновациями и организации бизнеса.

Ключевые слова: производственный аутсорсинг, промышленность, предприятие, инновационное развитие, инновации, рынок.

INTRODUCTION. The Ukrainian economy is in a crisis now that is caused by the long-term political and economic instability in the country. Industrial enterprises operate in conditions of national currency instability, economic relationships breaking, the loss of sales markets and the lack of sufficient investment resources. Industrial enterprises don't have enough funding for innovative development, improvement of their products and renewal of fixed assets. Due to globalization and the rapid development of scientific and technological progress, competitive advantages are achieved by enterprises that are actively introducing innovations into their activities. At the same time, it's impossible to keep business in competition for those enterprises that don't have any ability to reach the modern technological level. It means that it will be very difficult for the Ukrainian industrial enterprises to get a worthy place in the global market by themselves.

Therefore, they need to use advanced forms of business organization that helps to achieve the industry leaders' level. One of these forms is outsourcing which has proven itself as a way to transfer innovations. The Ukrainian industrial enterprises should consider the possibility of performing separate processes of the production cycle or the entire production process for the world famous brands. It will allow them to get some experience, use advanced technologies and introduce innovations into their work. The Ukrainian industrial enterprises have all the prerequisites for entering the world market of industrial outsourcing. The country has a sufficient amount of educated professional labor resources with practical experience and low wages. Also, there are a lot of industrial enterprises and research organizations with good potential. But they lost their competitiveness due to the lack of funding and obsolescence of the material base. It's necessary to realize that all changes at the national level and at the level of most enterprises can provide the attractiveness of domestic companies for foreign partners.

LITERATURE REVIEW. The globalization trends create a lot of conditions for a further global division of labor and the allocation of countries specializing in the outsourcing for certain services and business processes. It should be noted, that Ukraine has all the chances to take a decent place in the global outsourcing market according to the low cost of labor and significant scientific, technological and intellectual potential. This will increase employment and stimulate the revival and development of individual sectors of the national economy. Also, outsourcing is well known as a way of innervations transfer, so it will help the Ukrainian industrial enterprises in their innovative development.

The analysis of publications of the Ukrainian and foreign scientists has shown the diversity of views on the definition of the outsourcing concept. Supporters of the functional approach in determining the economic essence of outsourcing are [12, HEJVUD, B., 2004; 16, LEMIŠ, K.M.,2010; 25, ZAGORODNIY, A.H., 
PATRYN, H.O., 2009]. According to other scientists [18, MOČERNYJ, S.V. et al., 2005; 22, STRILETZ, V. et al., 2010], outsourcing is a kind of partnership interaction between business entities and it is a way of cooperation. Researchers [7, DOMINGUEZ, L., 2006; 15, KOHAN, V.P., 2013] see the main importance of outsourcing in the possibility of attracting resources from other organizations, especially labor, material, technical, intellectual, etc.

The globalization aspect of outsourcing is considered by Duginec' G.V. [8, 2012]. We can generalize the basic approaches to outsourcing definition:

- functional (outsourcing is the process of transferring individual functions or business processes of the enterprise to external executors on a long-term, paid basis);

- cooperative (outsourcing is a form of business relations based on partnership, where the performer provides and develops certain aspects of its activity in the interests of the customer, while both participants are equally interested in the success of the common cause);

- resource (outsourcing is the use of labor, material, intellectual, technical resources of a third-party organization);

- organizational (outsourcing is a form of business organization the implementation of which is accompanied by the reorganization of the enterprise that may be characterized by optimization of the organizational structure or the separation of the enterprise unit into a separate economic entity or the withdrawal of it and all related assets to the organization of the service provider);

- strategic (outsourcing is an enterprise management strategy that allows focusing on key competencies);

- target (outsourcing is a method of optimization and increase of efficiency of the enterprise activity, increase of competitiveness, increase of economic safety and stability of the enterprise, crisis management, increase of the cost of the enterprise, etc. due to the concentration of efforts on the main activity);

- globalization (outsourcing is an instrument of the globalization of the world economy, a way to include all subjects of world economic relations in the system of global cooperation, which provides for deepening the specialization of individual regions for the implementation of certain business processes for international customers).

It can be argued that outsourcing is a modern form of business organization that promotes the globalization of the international economy and the creation of powerful virtual organizations around a parent company that owns a trademark or brand and provides all other business processes including production to third-party executives who are interested in common success with the customer on a longterm, paid basis in order to ensure the efficiency of the activity, increase the competitiveness and stability of the enterprise as well as its flexible in accordance with current external conditions. Globalization trends create more and more conditions for the further distribution of labor and responsibilities determining the countries specializing in outsourcing of some services and business processes. According to the low labor cost and significant scientific, technological and intellectual potential Ukraine, it has all the chances to take a decent place in the international outsourcing market, which will increase employment and stimulate the revival and development of individual sectors of the national economy.

The development of outsourcing in different countries of the world has been studied by many scientists, including [2, BABANIN, O.S., 2012; 7, DOMINGUEZ, L., 2006] and others. Provided investigations are aimed for determining the role of outsourcing in the modern Ukrainian economy and the possibility of adopting the world experience of its application to domestic realities, market structure of outsourcing services and its main trends.

The major trends in the global outsourcing market based on a number of publications of the consulting firms allow making some conclusions. It was found currently that the Asia-Pacific region is the leader in the supply of outsourcing services. The leaders among the countries are India, China, Vietnam, Philippines and Malaysia. The most successful European providers of outsourcing services are Ireland and Poland. There were investigated the Top 100 Outsourcing Destinations by Tholons agency, Global Outsourcing Index and Future Outsourcing Index developed by Minevich M., Richter F.J. $[17,2015]$, IT Outsourcing Review by CEEOA.

Assessment of attractiveness of the region as an outsourcer should be primarily based on the balance of indicators such as the order of execution risks in the country and its cost. Special attention 
should be paid to the availability of human resources, transport infrastructure, and communications, the overall development of the country. The customer placing orders for manufacture outsourcing will be interested in the quality of manufactured products and low risks. Formation of the country as a successful manufacturing outsourcing will take place if it has industrialized regions, cities-centers of innovation characterized by a large number of industrial enterprises and research institutions; effective public support; developed business environment in the country and its regions.

Unfortunately, Ukraine has not found its place in the outsourcing market yet. The high level of corruption, economic and political instability repel foreign companies from placing outsourcing orders in Ukraine. IT-outsourcing is the only sector in which Ukraine has succeeded. It is done due to the high intellectual potential of national experts and the possibility to develop this activity without significant investment costs. But Ukraine should evolve towards the provision of outsourcing services in other activities. Ukraine could become a powerful manufacturing outsourcer because it has a large number of industrial companies that have production facilities, skilled workers and engineers. The development of manufacturing outsourcing will improve the economic situation of the enterprises and promote the development of the national economy.

METHODOLOGY AND RESEARCH METHODS. It has been considered an important scientific problem such as the search for an effective way to intensify the innovative development of Ukrainian industrial enterprises. This should happen due to their entry into the global market of manufacturing outsourcing. This is a new approach to innovative development as previously scientists have suggested that companies provide it on their own or at the funds of investors but not through a long-term strategic partnership like outsourcing.

In order to ensure the innovative development of the Ukrainian industrial enterprises in the global manufacturing outsourcing market, it is expedient to use the following methods [11, GLUSHAK, N., GLUSHAK, O. et al., 2016]: analysis, that is the division of the object of research, that means the innovative development of the the Ukrainian industrial enterprises at the global manufacturing outsourcing market into its components to improve the knowledge of the process and phenomena being studied; synthesis, which is the combination of difficulties and opportunities of the Ukrainian industrial enterprises into a single whole in order to establish their possibilities for innovation development with the help of manufacturing outsourcing at the global market; theoretical generalization, that helps to make general conclusions and develop some recommendations and show the result of the research for the release of the Ukrainian industrial enterprises to the global market of manufacturing outsourcing to ensure their innovative development; comparison, that is, calculation of the rate of the Ukrainian enterprises' development by the main macroeconomic indicators and determining the dynamics of their changes; statistical analysis, that is used for converting empirical data obtained during the study into the meaningful analysis, hypothesis testing and interpretation; expert evaluation, which enables to describe the qualitative characteristics of the investigated process.

The theoretical basis of the study is the works of scientists on the implementation of outsourcing in the activities of enterprises, data of rating agencies and statistical information. The aim of the article is to develop recommendations for the release of Ukrainian industrial enterprises in the global market of manufacturing outsourcing to ensure their innovative development. For this purpose, the article proposes to investigate how the implementation of outsourcing orders will facilitate the transfer of innovations; identify the main types of industrial outsourcing; determine the criteria by which enterprises should choose a type of outsourcing for supply to customers.

RESULTS. Development of the Ukrainian economy requires new approaches to business organization. Old methods and forms of management can't provide sustainable development. We can estimate an economic situation in Ukraine using international rankings. Ukraine has rank 71 among 190 countries according to one of the most famous rankings Doing Business that characterize ease of business performance in different countries of the world [6, 2019].

Another ranking Global Competitiveness Index gives a rank 83 to Ukraine among 140 countries [10, SCHWAB, K., 2018]. It assesses the microeconomic and macroeconomic foundations of national competitiveness, which is defined as the set of institutions, policies, and factors that determine the level of productivity of a country. According to the similar World Competitiveness Ranking developed by the World Competitiveness Center Ukraine's rank looks worse, it's only 59th 
out of 63 countries $[13,2018]$. This index is an annual study of global competitiveness, assesses and analysis of the countries' ability to create and maintain an environment in which enterprises may effectively compete. We can see that world researchers don't see Ukraine as a competitive, developed and attractive country for doing business. This situation reduces its image as an economic partner in the international arena. It obstructs the establishment of sustainable economic relations and attraction of investments. It's especially reflected in the activities of industrial enterprises due to the deterioration of political relations with some ex-USSR countries, lost regular customers of their products and remained without stable contracts.

The industrial sector of the Ukrainian economy is characterized by a large number of economic entities and has strategic significance for our state providing majority people with their positions. There are 2,386 business entities in the industry in Ukraine. Among them, there are 42,026 enterprises and 81,850 private entrepreneurs. The industry provides the position with 2,334.2 thousand people, but after of the crisis in Ukraine, the number of employees in the industry decreases annually. Using the advice of experts [21, 2019], we can compare this situation with 2011 when industrial enterprises of Ukraine employed $3,031.7$ thousand people. The number of sales in recent years has been stable but increased last year. According to the great inflation, one can say about inhibition of sales. Therefore, one can conclude that there is a deceleration of the development in the industrial sector of Ukraine and the high probability of a largescale crisis in this sector of the economy. Particularly disappointing is the annual decrease in the number of large industrial enterprises which provide a significant number of position and a major share of output.

Successful operation of industrial enterprises must be supported by the high-quality personnel which has professional knowledge and skills inclined to innovate and have intellectual, scientific and technical potential. Unfortunately, industrial enterprises cannot provide sufficient wages. Using official statistics [21, 2019], we can see that the average wages in the industry are UAH 10,236 per month. It hasn't promoted the attraction of highly skilled personnel in this area recently. Lack of interest to the enterprises' results and high-skilled personnel inflows causes lack of innovation development and improvement of labor efficiency. The efficiency of industrial enterprises depends on the availability and conditions of the necessary fixed assets. Wear factor is $58 \%$ now, that could lead to a technical crisis at the industrial enterprises. The renovation of fixed assets at industrial enterprises requires significant investments.

Also, we can see the low innovative activity of industrial enterprises. Only $14,3 \%$ of industrial enterprises implemented innovations in 2017 [21, 2019]. 1,831 new technological processes were implemented, including 748 low-consumption and resource-saving ones, and the launch of 2,387 items of innovative products, including 751 new types of equipment this year. However, the share of implemented innovative products in the volume of industrial goods is still a fairly low share, only $0,7 \%$. And, as it has been proved by official statistic information [21, 2019], since 2000 this indicator has decreased almost 10 times. This suggests the backlog of domestic industrial enterprises from the global scientific and technological progress and their low attention to the introduction of the latest technological advancements in the production and updating of products. This can lead to a technological crisis at the industrial enterprises. There is a negative trend of decreasing investments in innovation development. The total amount of costs for innovation activity was UAH 9,117.5 in 2017 $[21,2019]$. To compare with 2016, these costs were UAH 23,229.5 in 2016. The largest amount of money - UAH 5,898.8 - was spent on the purchase of machines, equipment, and software [21, 2019]. The main source of financing remains in the own funds of enterprises is not enough to update the innovative potential of Ukrainian industry under current conditions. The World Intellectual Property Organization, Cornell University, and the Insead international business school annually calculate the Global Innovation Index that takes into account such indicators as human capital, development of education, business environment, availability of intangible assets and number of intellectual workers. According to the Global Innovation Index [23, DUTTA, S., et al., 2018], Ukraine has rank 43 among 126 countries of the world. This rank is very low taking into account a great number of industrial enterprises, research organizations, and universities situated in Ukraine.

On the basis of the analysis, it is possible to make some conclusions about the high probability of crisis phenomena at industrial enterprises. The deterioration of the financial activity of enterprises has an impact on the development of the financial crisis. It is accompanied by reduction insolvency and the possibility of 
attracting investment resources that are necessary for enterprises. Lack of labor resources and low wages can lead to a reduction in labor productivity and employee interests in companies' development that could indicate the organizational crisis. Violations of economic relationships, the absence of new supply channels and markets can lead to a sales crisis. Therefore, talking about the innovative development of domestic industrial enterprises one can say that it's very difficult today because it requires significant financial infusions. It will be almost impossible for the enterprises to get out of a crisis and restore their innovative potential by themselves, therefore, it is necessary to seek help from the third parties.

Considering outsourcing as a way of industrial enterprises innovation development it's necessary to pay more attention to the concept of innovation. Innovations are newly created and improved competitive technologies, products or services, as well as organizational and technical decisions of an industrial, administrative, commercial or other nature that significantly improve the structure and quality of production and the social sphere. Objects of innovation activity are: innovative programs and projects; new knowledge and intelligent products; production equipment and processes; infrastructure of production and entrepreneurship; organizational and technical decisions of an industrial, administrative, commercial or other nature that significantly improve the structure and quality of production and social sphere; raw materials, means of their extraction and processing; commodity products; mechanism of formation the consumer market and marketing of commodity products. Innovative development is based on the continuous search and use of new ways and areas of realizing the potential of the enterprise in changing environmental conditions within the framework of the chosen mission and the accepted motivation of activities related to the modification of existing and the formation of new markets. Innovation activity is aimed at the use and commercialization of the results of research and development and promotes the launch of new competitive products and services on the market. As it was mentioned, it would be very difficult for Ukrainian industrial enterprises to provide innovation development on their own. Therefore, it's necessary to get long-term business agreements with leaders of scientific and technological progress. Ukrainian enterprises can offer to their partners themselves as industrial outsourcers. Foreign companies will be able to reduce the cost of the production process due to its partial or full implementation in Ukraine, and Ukrainian enterprises will receive experience, investment, technology, personnel training, etc.

The customer of outsourcing services has financial, material and intellectual resources. By concluding a long-term contract for transferring part or the entire production process to an outsourcer in additional to the order he transfers his intellectual capital first of all. As a result, the outsourcer makes an innovative breakthrough in introducing technological, product, organizational, process and other innovations. In addition, if the customer is interested in a long-term partnership, he can become an investor in the outsourcer, help him with the organization of logistics and staff training. There are good preconditions for the entry of Ukrainian industrial enterprises in the global outsourcing market. Most machine-building enterprises or research institutions in Ukraine were created in USSR times. Almost all of them were not economic entities with a closed cycle of production but engaged in the development and production of individual parts and units. The final product was the result of the work of a large number of enterprises located in different parts of the former USSR. For example, the Kharkiv machine-building plant "FED" produced hydraulic, fuel and electric systems for aviation engineering. Some units were supplied to the "Rubin" plant located in the Moscow region. "Rubin" manufactured runways, hydro units and hydro systems for airplanes and other aircraft. Its products were supplied to aviation and helicopter factories of the USSR, located in Voronezh, Kaliningrad, Kyiv, Lviv and other cities, and back in Kharkiv - to the Kharkiv Aviation Plant. Aircraft design was provided by separate organizations: Antonov (Kyiv), Tupolev (Moscow), Mikoyan (Moscow), Sukhoi (Moscow). Also the production of FED plant was supplied to the Motor Sich plant, which produced engines for airplanes and helicopters for all aircraft and helicopters factories throughout the USSR.

We can say that domestic industrial enterprises were created as production outsourcers, or endproducers, which transferred part of the production cycle for outsourcing to other enterprises of the USSR. The economic ties created at that time remained until 2014. However, at the moment, with the violation of diplomatic relations with Russia and the inability to interact in the defense industry and scientific and technical cooperation, Ukrainian enterprises were in a situation where the final products themselves can't produce, and the production chain of several enterprises is broken. Therefore, today the way out of this 
situation is possible only through the search for customers to perform part of production processes from Europe and Asia and the establishment of new economic ties.

Today manufacturing outsourcing is an opportunity for economic recovery and innovation development of Ukraine. There are several directions of the possible way to the global market of manufacturing outsourcing for Ukrainian enterprises (fig. 1). We can define four types of manufacturing outsourcing, such as research and development outsourcing, certain parts of the production process outsourcing, assembly operations outsourcing and full manufacturing outsourcing. Ukrainian industrial enterprises could be competitive in the global outsourcing market if they chose the most suitable type of outsourcing to offer to customer. We highlight preconditions of use of each type of manufacturing outsourcing and possible difficulties that the enterprise may face. Also, we provide some examples of successful providing of outsourcing services below to customer.

There is a considerable number of scientific research institutes in Ukraine since the times of the USSR. They may become competitive in the outsourcing market of research and development activities. The specifics of such institutions still remain wide. There is Institute of Mono Crystals, Institute of Mechanical Engineering of the National Academy of Sciences of Ukraine, O.Y. Usikov Institute for Radiophysics and Electronics, National Science Center "Kharkiv Institute of Physics and Technology", Kharkiv Scientific Research and Design Institute "Energoproekt", Institute of Radio Astronomy of the National Academy of Sciences of Ukraine, etc. in Kharkiv (Ukraine). However, not all of them, unfortunately, have sustained economic ties, commercialization of their developments and participation in international production outsourcing projects. A successful example is a project of creating a space system for global monitoring of the dynamic processes in the Earth's ionosphere, as part of the European GMES program, the space weather program SW and the global GEOSS system. The main executor of the project in Ukraine is Space Research Institute National Academy of Sciences of Ukraine. Also we can mention the implementation of the Sea Launch project by the International Company. Launch vehicle Zenit developed by the Design office Yuzhnoye and manufactured at the Production Association Yuzhny Machine-Building Plant named after A.M. Makarov was used as part of the floating missile and space complex. 36 launches of Zenit-3SL launch vehicles with spacecraft for telecommunication purposes were established on the naval platform from April 1999 to December 2014 [5, 2019]. This project is an example of Ukrainian enterprises' action as outsourcers at research and development work, as well as parts of the production process. Unfortunately, the participation of Ukrainian research institutes in such projects is not a widespread practice. It's necessary to provide the training of Ukrainian scientists in internships in innovative world countries and the development of international scientific and technical cooperation.

It is advisable to carry out certain parts of the production outsourcing process for enterprises that have sufficient production capacity and qualified personnel, but don't have a closed production cycle or their final products are uncompetitive but individual nodes, aggregates or production processes are executed at a high level. Such enterprises are the majority of the machine-building enterprises of the former USSR. The powerful enterprise of defense complex State Enterprise "Malyshev Plant" produced diesel engines 6TD-2 for the upgraded version of Al-Khalid tank, which was developed by the Chinese company Norinco and Pakistani Heavy Industries. The tank was manufactured almost entirely on the production facilities of Pakistan except for the engine as Ukraine is capable of manufacturing one of the most reliable models of tank engines working in a hot climate. The Ukrainian engines are also popular for airplanes. A well-known manufacturer of engines for airplanes and helicopters Motor Sich produced engines for Ukrainian and Russian enterprises for a long time. However, due to the political situation in Ukraine the company finds new markets. Motor Sich and the South African company Paramount Group signed a memorandum of cooperation on the joint modernization of military helicopters Mi-24 Super Hind. Companies will explore the possibility of technology exchange. Also, Paramount Group is interested in expanding its cooperation with Ukraine in the production and repair the helicopter engines. In its turn, Motor Sich is extremely interested in technologies related to the production of composite blades for helicopter screws. At the same time, Motor Sich actively cooperates with China providing aircraft engines AI-222K-25, AI-222K-25F and component parts for an L-15 aircraft. The company manufactures, tests, maintains and repairs 55 types and engine modifications for 61 types of aircraft and helicopters of different purposes, operated in 109 countries of the world now [20, 2019]. 


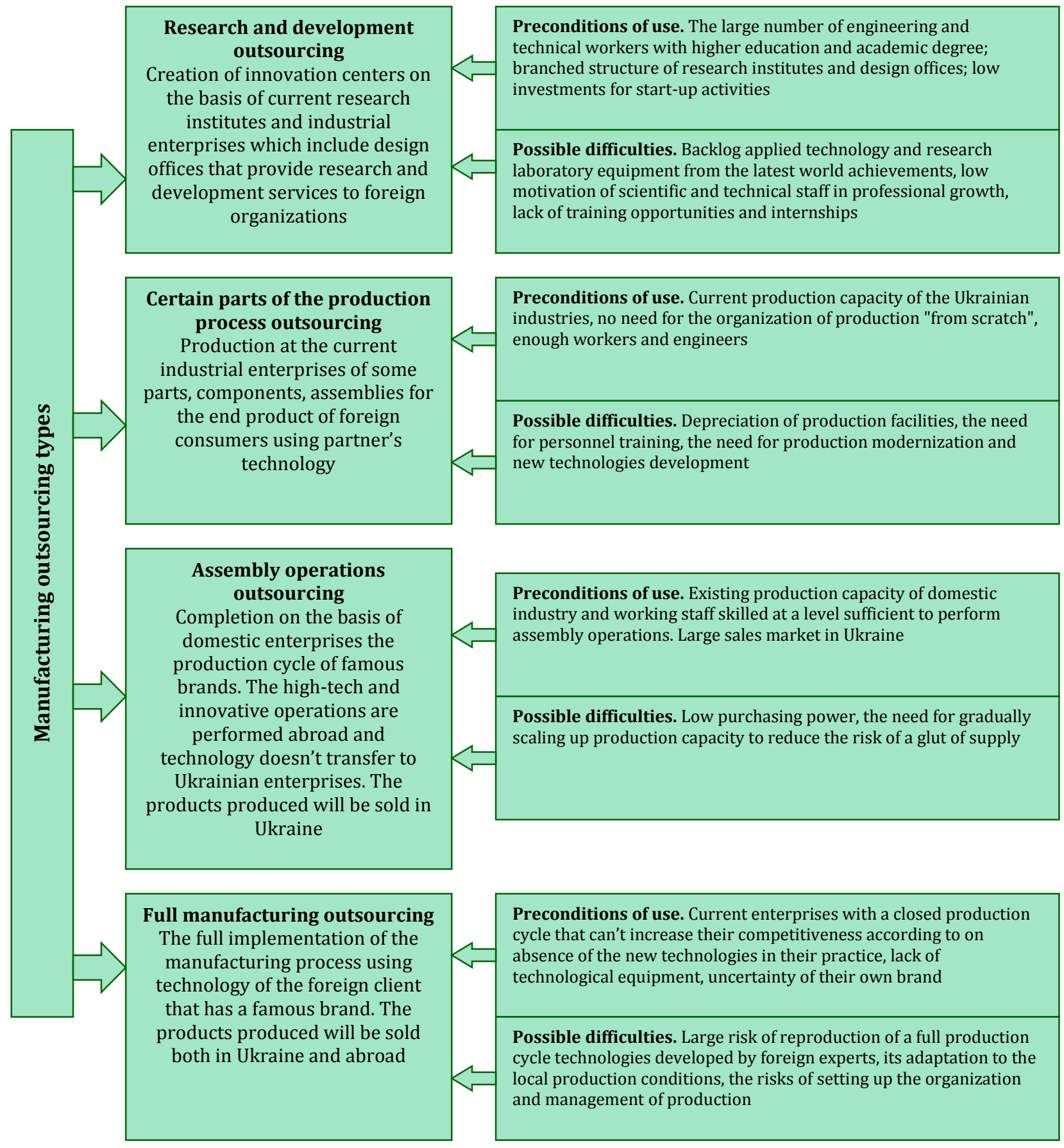

Figure 1. Involvement of the Ukrainian industrial enterprises as manufacture outsourcers Source: Made by authors.

Assembly outsourcing operations that is the final stage of the production process is appropriate for enterprises located near the market of products. It's relevant for products which importation into Ukraine is inconvenient and economically inappropriate given the heavy transportation and significant customs duties. Cars are the kind of such products. As an example, one can mention the production of the Czech brand "Skoda" cars at the Ukrainian company Eurocar. Eurocar is the official producer of VW Group cars in Ukraine that is part of the Atoll Holding group of companies. The plant was opened in December 2001. Eurocar produces the whole range of the brand "Skoda" cars at the moment. The enterprise carries out full-scale production of cars, which includes such major production processes as welding, painting, and assembly of automobiles. The production capacities 
of the plant allow to produce up 100 thousand cars per year and give an opportunity to increase the level of localization of cars produced with the prospect of export development. Welding and dyeing are carried out by the equipment of such well-known companies as Transsystem (Poland), Chropynska Strojirna (Czech Republic), EISENMANN (Germany) [9, 2019]. Creating such a production plant is relatively simple since production capacity is only needed to complete the production process such as welding, painting, and installation. The main preliminary work on manufacturing units and assemblies is carried out at the enterprises of the Czech Republic and Slovakia. This project is of great importance for the development of such Ukraine's scientific and technical potential as technologies are being transferred along with production to the enterprise that will help to improve the skills of Ukrainian specialists.

Provision of full outsourcing services is possible for enterprises that have all the necessary resources to carry out the entire production cycle or the major part of it and don't produce their own products because of its non-competitiveness or no known on the market. In this case, it is more appropriate to take orders for the production of branded products by the technology of the original manufacturer. This may include the possibility of upgrading production capacities, mastering the latest proven technologies and upgrading staff skills. The complete production process for outsourcing was transferred by Daewoo Motors to AvtoZAZ. Daewoo Motors acted as an investor of AvtoZAZ. In 1998 it was invested \$150 million in its authorized capital. In addition to investments Daewoo Motors has provided new technologies, unique quality control systems and own engineering developments. Due to this action there was provided a renovation of production, buildings, energy supply systems, engineering structures and networks at factories in Zaporizhzhya, Melitopol, Chernomorsk, organized quality control of products according to the world standards; the production of Tavriya Nova was restored after modernization at the main plant in Zaporizhzhya; administrative personnel policy was changed. The restoration of the enterprise and bringing its technological base to the world standards was a contribution to the further attraction of new investments as a result of cooperation with Daimler Chrysler, General Motors, Opel, Renault, etc. The result of this cooperation was the mass production of well-known cars in Ukraine: Daewoo Lanos, Daewoo Sens, Chevrolet Aveo $[1,2019]$. This example shows how an enterprise that produces uncompetitive products and owns an unremarkable brand decides to renounce its own name and manufacture cars of other well-known brand and became a leader in the automotive industry in Ukraine for decades.

The Ukrainian industrial enterprises have a lot of opportunities to enter the global outsourcing market successfully. The provision of outsourcing services helps to attract foreign investments and technologies. Successful outsource enterprises may become leading producers of their industry, create their own brands, begin to produce products focused both on the domestic market and delivered to export. Participation in international outsourcing agreements has national importance due to creating new jobs, growth workers' welfare, the inflow of foreign currency funds from abroad. Also, the outsourcing should be mentioned as an instrument of transfer of technologies and the activation of innovation activity of industrial enterprises.

We can see how to choose of the type of manufacturing outsourcing and ways of innovative development depending on characteristics of the enterprises in fig. 2. Industrial enterprises can intensify their innovative activities by obtaining outsourcing orders from high technology enterprises. We can see that enterprises that have closed production cycle and well-known brand should produce goods under their own brand. In this case, their innovation development will be provided by their own resources. But for enterprises not known on the market, this way isn't available. They have to manufacture products of famous brands at their production facilities to provide themselves with orders. But the customer transfers his intellectual capital to the outsourcer in addition to his order. Innovative development, in this case, is provided by transferring the technological process, personnel training, re-equipment of production facilities. Industrial enterprises that could provide only some parts of the manufacturing cycle may be competitive in other types of outsourcing. Some of them that have significant scientific and technical potential should provide services of research and development outsourcing. In this case, Innovative development is provided by scientific and technical cooperation, exchange of experience, assistance in equipping laboratories, research bases. If the enterprise has only manufacturing potential, it could provide 
services of certain parts of the production process outsourcing. But if it located next to the market of products it is advisable to offer services of assembly operations outsourcing. Innovative development will be provided by sharing experience, development of new technologies, re-equipment of production facilities and staff development.

We conducted a study of choice the type of manufacturing outsourcing for some Ukrainian industrial enterprises. We used data of official websites of enterprises and the results of the survey of employees of enterprises. The results of the study are in table 1. Each indicator was evaluated on a scale from one to five.

Table 1

The choice of the type of manufacturing outsourcing of Ukrainian industrial enterprises

\begin{tabular}{|l|c|c|c|c|c|}
\hline \multicolumn{1}{|c|}{ Enterprise } & $\begin{array}{c}\text { Ability to carry } \\
\text { out a closed } \\
\text { production cycle }\end{array}$ & $\begin{array}{c}\text { Well-known } \\
\text { brand in the } \\
\text { market }\end{array}$ & $\begin{array}{c}\text { Significant } \\
\text { scientific and } \\
\text { technical } \\
\text { potential }\end{array}$ & $\begin{array}{c}\text { Location next } \\
\text { to the } \\
\text { market of } \\
\text { products }\end{array}$ & $\begin{array}{c}\text { Recommended type } \\
\text { of manufacturing } \\
\text { outsourcing }\end{array}$ \\
\hline $\begin{array}{l}\text { XTZ (Kharkiv } \\
\text { Tractor Plant) }\end{array}$ & 5 & 4 & 4 & 4 & $\begin{array}{c}\text { Production under its } \\
\text { own brand }\end{array}$ \\
\hline $\begin{array}{l}\text { Kharkiv Aviation } \\
\text { Plant }\end{array}$ & 2 & 4 & 5 & 3 & $\begin{array}{c}\text { Research and } \\
\text { development } \\
\text { outsourcing }\end{array}$ \\
\hline $\begin{array}{l}\text { Tinyakova } \\
\text { Garment Factory }\end{array}$ & 5 & 1 & 3 & 3 & $\begin{array}{c}\text { Full manufacturing } \\
\text { outsourcing }\end{array}$ \\
\hline Eurocar & 1 & 1 & 3 & 5 & $\begin{array}{c}\text { Assembly operations } \\
\text { outsourcing }\end{array}$ \\
\hline Malyshev Plant & 3 & 2 & 3 & 3 & $\begin{array}{c}\text { Certain parts of the } \\
\text { production process } \\
\text { outsourcing }\end{array}$ \\
\hline
\end{tabular}

Source: Made by authors based on [1, 2019; 9, 2019; 20, 2019].

The analysis provided in table 1 helps industrial enterprises to choose the recommended type of manufacturing outsourcing that makes the company occupy a competitive position in the global market for manufacturing outsourcing.

CONCLUSIONS. The main idea of the article is that for the Ukrainian industrial enterprises one of the most effective ways of innovation development is to active offer of their services in the global manufacturing outsourcing market. Ukraine has a good chance to become a successful outsourcing country according to high intellectual and personal potential, the existing material base and the low cost of services offered. Outsourcing contracts will help to attract investment in industrial development, provide an exchange of experience and technology with leading world countries. Ukrainian industrial enterprises can offer foreign customers research and development outsourcing, certain parts of the manufacturing process outsourcing, assembly operations outsourcing and full manufacturing outsourcing.

The scientific result of the study is the development of recommendations on the choice of type of manufactural outsourcing that is advisable for Ukrainian industrial enterprises to enter the global industrial outsourcing market. Enterprises need to assess the strength of their own brand, the ability to implement a closed production cycle on their own production facilities, their scientific and technological potential and proximity to markets to choose a type of outsourcing.

The results of the research can be used by industrial enterprises in strategic management, business organization forms selection and outsourcing contracts. The results can be also used to develop a methodology for assessing the attractiveness of industrial enterprises as manufactural outsourcer in the future. 


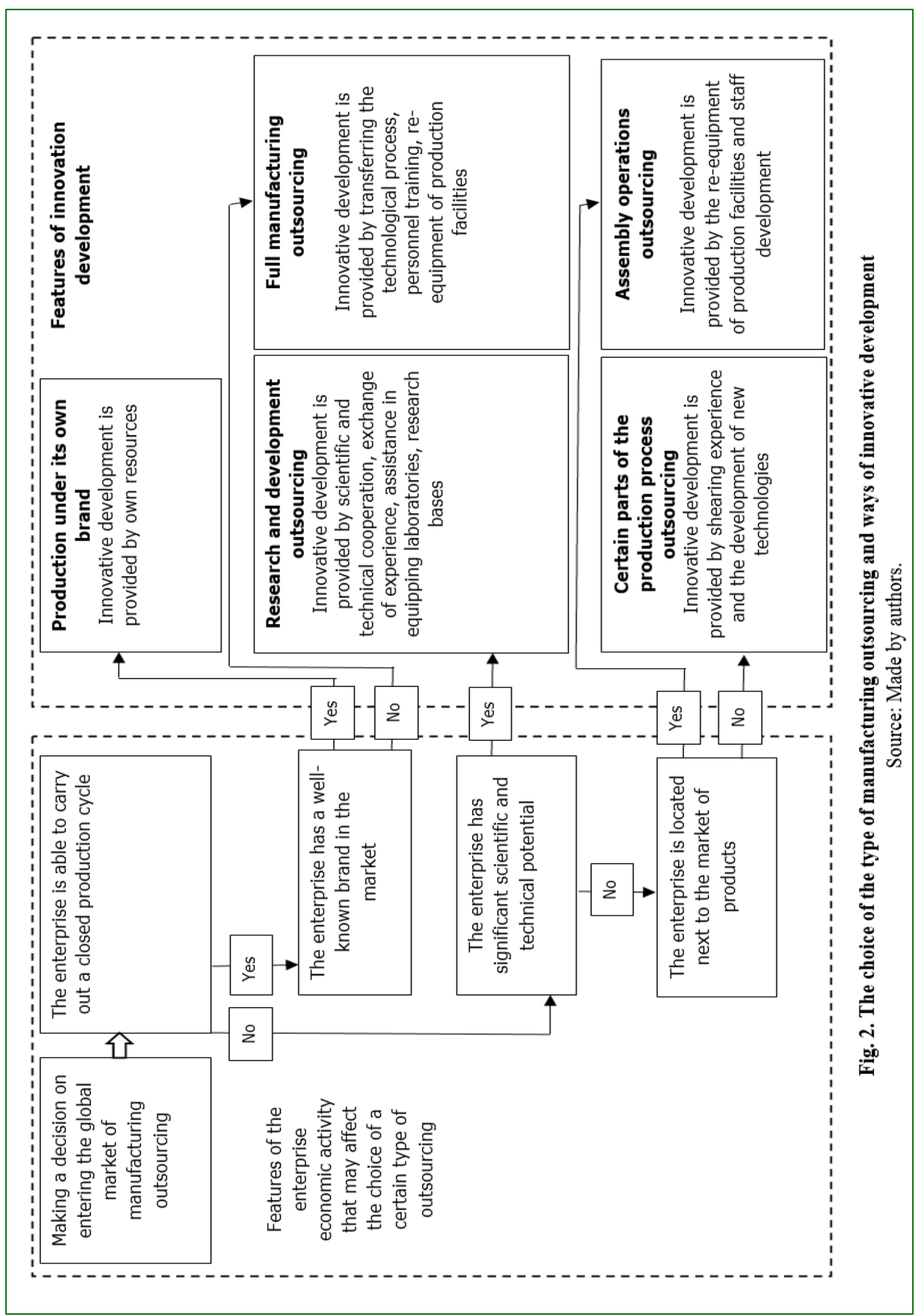

No. 2 / 2019 


\section{REFERENCES}

1. AvtoZAZ company. 2019. [Accesat 23.05.2019]. Disponibil: http://www.avtozaz.com

2. BABANIN, O.S. Ekonomična spivpracâ Ukraïni i SŠA: IT-sektor. In: Zovnišnâ Torgivlâ: ekonomika, finansi, pravo. Kï̈v, 2012, № 5, ss. 27-32. ISSN 2616-6100.

3. Competitiveness Rankings. World Economic Forum. 2018. [Accesat 11.10.2019]. Disponibil: http://reports.weforum.org/global-competitiveness-report-2018/competitiveness-rankings

4. IMD World Competitiveness Online. 2018. [Accesat 26.08.2019]. Disponibil: https://worldcompetitiveness.imd.org

5. Design Office Yuzhnoye. 2019. [Accesat 12.10.2019]. Disponibil: https://www.yuzhnoye.com/en/home

6. Doing Business. 2019. [Accesat 17.05.2019]. Disponibil: http://www.doingbusiness.org/en/rankings

7. DOMINGUEZ, L. The manager's step-by-step guide to outsourcing. New York: Megraw-Hill, 2006. 226 p. ISBN 9780071458245.

8. DUGINEC', G.V. Vpliv Mižnarodnogo autsorsingu na rozvitok lûds'kogo kapitalu v umovah globalizaciï. V: Problemy i perspektivy razvitiâ sotrudničestva meždu stranami Ûgo-Vostočnoj Evropy v ramkah ČĖS i GUAM. Albena-Doneck, 2012, ss. 124-128. ISSN 1990-9187.

9. O0O EvroKar. 2019. [Accesat 23.05.2019]. Disponibil: https://ru.skoda-auto.ua/company/about

10. SCHWAB, K. The Global Competitiveness Index: insight report. 2018. [Accesat 17.08.2019]. Disponibil: http://www3.weforum.org/docs/GCR2018/05FullReport/TheGlobalCompetitivenessReport2018.pdf

11. GLUSHAK, N., GLUSHAK, O. et al. Innovative methods of industrial enterprises management based on the universal network model. 2016. [Accesat 17.09.2019]. Disponibil: https://www.shsconferences.org/articles/shsconf/pdf/2016/06/shsconf_rptss2016_01041.pdf

12. HEJVUD, B. Autsorsing: v poiskah konkurentnyh preimuŝestv. Moskva: Vil'âms, 2004. 176 s. ISBN 58459-0398-X.

13. IMD World Competitiveness Rankings. 2018. Disponibil: https://www.imd.org/globalassets/wcc/docs/release-2018/ranking2018.pdf

14. IT Outsourcing News from Central and Eastern Europe. 2017. [Accesat 23.05.2019]. Disponibil: http://itonews.eu

15. KOHAN, V.P. Autsorsing i dogovori, ŝo jogo oposeredkovuût'. V: Дepžavne budivnictvo тa misceve samovrâduvannâ. 2013, vip. 26, ss. 159-174. ISSN 1993-0941.

16. LEMIŠ, K.M. Metodika prijnâttâ rišen' z vikoristtannâ autsorsingovih tehnologij. V: Naukovi Praci Nacional'nogo Universitetu Harčovih Tehnologij. 2010, № 34, ss. 61-63. ISSN 2617-1945.

17. MINEVICH, M.D., RICHTER, F.J. The Global Outsourcing Report. Opportunities, Costs and Risks. 2015. [Accesat 11.08.2019]. Disponibil: https://www.markminevich.com/pdf/WB_FINAL.PDF

18. MOČERNYJ, S.V., LARINA, Y.S., USTENKO, O.A., ÛRIJ, S.I. Ekonomičnyj enciklopedičnyj slovnik: u 2-h tomah. Tom 1. Lviv, 2005. 616 s. ISBN 966-603-425-5.

19. Tholons Releases 2018 Services Globalization Index - Digital at Scale. [Accesat 23.05.2019]. Disponibil: http://www.digitaljournal.com/pr/3969690

20. State Enterprise "Malyshev Plant" military and civilian technology. 2019. [Accesat 23.05.2019]. Disponibil: https://www.malyshevplant.com/en

21. State Statistics Service of Ukraine (2017-2019). [Accesat 27.10.2019]. Disponibil: https://ukrstat.org/en/menu/publikac_e.htm

22. STRILETZ, V., KARCHYLOVA, N, SAPRYKINA, N. Efficiency of using outsourcing on railway transport and methods of its estimation. In: Economics and Management Journal. 2010, vol. 15, pp. 102-110.

23. DUTTA, S., LANVIN, B., WUNSCH-VINCENT, S. The Global Innovation Index. Energizing the world with innovation. 2018. [Accesat 11.07.2019]. Disponibil: https://www.globalinnovationindex.org/userfiles/file/reportpdf/gii_2018-report-new.pdf

24. Top 50 Emerging Global Outsourcing Destinations 2009. [Accesat 23.05.2019]. Disponibil: http://www.tholons.com/top50.html

25. ZAGORODNIY, A.H., PATRYN, H.O. Autsorcing and its impact on the cost of enterprise. In: Finance of Ukraine. 2009, vol. 9 (166), pp. 87-97. ISSN 2305-7645.

\section{ARTICLE HISTORY}

Received 09 September 2019

Accepted 24 September 2019 


\title{
EXTERNAL DEBT IMPLICATIONS \\ ON THE DEVELOPMENT OF NATIONAL ECONOMY
}

\author{
Victoria IORDACHI', PhD in Economics, Associated Researcher, \\ National Institute for Economic Research, Republic of Moldova \\ Stela CIOBU ${ }^{2}$, PhD in Economics, Associated Professor, \\ Academy of Economic Studies of Moldova
}

\author{
DOI: https://doi.org/10.36004/nier.es.2019.2-03 \\ JEL Classification: E42, E52, E58 \\ UDC: $336.273 .3(478)$
}

\section{ABSTRACT}

The external debt of the Republic of Moldova is increasing constantly. Excessive external debt has been a big problem for both developing and developed countries during the years. Developing countries face this problem more often as they need to borrow to finance their objectives and strengthen the economic growth. It is very important for our country to determine the optimal level of indebtedness that the economy can bear. That is why the external debt should be contracted in strict accordance with the needs of the economy, and borrowed loans should consider the country's reimbursement capacities to avoid the liquidity or solvency crisis. The scope of this paper is to give a prompt and correct overview of the importance of external debt management and its impact on the economic growth of the country. In the research process, the deduction, based on general theoretical information on the structure, management, external debt and indebtedness assessment, the economic influence policies were used and then passed on to practical analysis using specific indicators.

Keywords: gross external debt, Gross Domestic Product, price stability, inflation pressures, foreign currency, economic crisis.

Datoria externă a Republicii Moldova este în continuă creștere. Datoria externă excesivă a fost o mare problemă atât pentru țările în curs de dezvoltare, cât și pentru cele dezvoltate de-a lungul anilor. Țările în curs de dezvoltare se confruntă mai des cu această problemă, întrucât trebuie să împrumute pentru a-și finanța obiectivele și pentru a consolida creșterea economică. Este foarte important pentru țara noastră să determine nivelul optim de îndatorare pe care economia îl poate suporta. Acesta este motivul pentru care datoria externă ar trebui contractată în concordanță strictă cu nevoile economiei și luând în considerare capacitătile de rambursare, pentru a evita criza de lichiditate sau de solvabilitate. Scopul acestei lucrări este de a oferi o imagine generală promptă și corectă a importanței gestionării datoriei externe și a impactului acesteia asupra creșterii economice a țării. In procesul de cercetare a fost utilizată deducerea bazată pe informații teoretice generale privind structura și managementul datoriei externe, precum și evaluarea îndatorării, politicile de influență economică și apoi analiza practică, folosind indicatori specifici.

Cuvinte-cheie: datora externă brută, Produsul Intern Brut, stabilitatea prețurilor, presiuni inflaționiste, valută străină, criză economică.

Внешний долг Республики Молдова постоянно увеличивается. В течение многих лет чрезмерная внешняя задолженность была большой проблемой как для развивающихся, так и для развитых стран. Развивающиеся страны сталкиваются с этой проблемой чаще, поскольку им необходимо брать кредиты для финансирования своих целей и усиления экономического роста. Для нашей страны очень важно определить оптимальный уровень задолженности, который может выдержать экономика. Вот почему внешний долг следует заключать в строгом соответствии с потребностями экономики, а заемные кредиты должны учитывать возможности их возмещения, чтобы избежать кризиса ликвидности или платежеспособности. Цель этой статьи - дать

1 C Victoria IORDACHI, $₫$ timush_v@yahoo.co.uk

2 (C) Stela CIOBU, stela.ciobu@gmail.com

No. 2 / 2019 
быстрый и правильный обзор значимости управления внешним долгом и его влияния на экономический рост страны. В процессе исследования использовалась дедукция, основанная на общей теоретической информации о структуре, управлении, оценке внешнего долга и задолженности, политике экономического влияния, а затем переход к практическому анализу с использованием конкретных показателей.

Ключевые слова: валовой внешний долг, валовой внутренний продукт, ценовая стабильность, инфляционное давление, иностранная валюта, экономический кризис.

INTRODUCTION. Excessive external debt has been a big problem for both developing and developed countries during the years. Developing countries face this problem more often as they need to borrow to finance their objectives and strengthen the economic growth. However, these borrowings have to be strictly managed and must be allocated properly for productive expenditures in accordance to their repayment ability. Though the debt is useful to supplement the capital, it must be managed and controlled very carefully, proper strategies have to be adopted for enforcing repayment ability of the country. High level of external debt has a negative impact on the economy in terms of heavy debt servicing and decreased development expenditures, essential in carrying the growth process. However, less funds for investing in the economy and an increase in tax regime for repayment, disturbs the economic growth as it constraints the productive investment, leading to a narrow debt repayment ability of the country. It has a negative impact on the foreign and national investment, and development objectives of the country.

The economic growth is one of the aspirations of all economies, as it leads to a rise in per capita income, to raising the standards of living of the population, to the overall development of the national economy, and, finally, to the economic progress.

A developing country in the transition from the centralized to the market economy cannot build a solid democracy, based on a competitive economy and a modernized economic and social infrastructure system, rather than by calling for funding external debt generating unit. Considered to be at the heart of the development of the capitalist economies, the credit is widely used at macroeconomic level. Both developed and developing countries resort to domestic or foreign credits because they offer them the opportunity to spend now and pay in a future period when the investment starts to make a profit.

I. The impact of the external debt on the national economy

External debt as a policy to promote economic growth creates serious debates between economists and the policy makers. The main issue is whether or not external borrowing leads to economic growth in debtor countries or affect it negatively. This issue results in two main perspectives for explaining the relationship between external debt and economic growth.

On the one hand, the neoclassical growth models support that there is a positive relationship between external debt and economic growth. They consider that external debt is one source for financing capital formation, and if financing capital formation through borrowing, it could promote the economic growth.

On the other hand, Krugman contradicts this view and tells that the external debt is one of the barriers that prevent the economic growth. Kalonji explained that excessive external debt is a cause of poverty in the debtors' countries [4, KRUGMAN, P., 1988].

This ideology shows us that a country should borrow from abroad as long as the capital is not sufficient and it will produce a rate of return that is higher than the cost of the borrowing. In this way, developing countries with an inadequate capital will keep borrowing to fill the national savings and investment. They will borrow at a rate that depends on the relation among foreign and national savings, investment and economic growth so in that way, the borrowing countries will increase their output with the help of foreign savings. This procedure will be effective only if the borrowing will be managed efficiently and the rate of return will be higher than the cost of borrowing.

Economic theories suggest that reasonable levels of external debt lead to an economic growth. Countries at early stages of development have small levels of capital and stocks and need the investments with less interest rate lower than in developed countries. As they use the borrowed funds adequately for productive purposes and do not suffer from macroeconomic instability, policies that twist the economic incentives, these funds will help the economy and lead to an economic growth and will allow for timely debt repayments [10, PATILLO, C., RICCI, L., 2002]. These theories are also proved in more realistic predictions that countries may not be able to borrow freely because of the risk of debt repudiation. 
The most common question for economist and policy makers is: Why do excessive debt leads to a lower economic growth? Well, the best known answer to this question comes from "debt overhang" theories, which show us that most likely, the debt will be higher than the country's repayment ability, and expected debt service costs will discourage further domestic and foreign investments, and will harm the economic growth. Potential investors will fear to invest as they will consider that if a country produces more, it will be taxed by creditors to service the external debt, and thus they will be willing less to incur costs today for the sake of increased output in the future. This argument claims that large debt stocks lead to a lower probability of debt repayment.

Although the debt overhang models don't show the effects on growth in particular, but it shows quiet certain that large debt stocks lower growth partly by reducing investments. Moreover, the incentive effects associated with debt stocks tend to reduce the benefits to be expected from policy reforms that would strengthen efficiency and growth, such as trade liberalization and fiscal adjustment. The government will be less likely to support current costs if it notices that the future benefit in terms of higher output will grow partly to foreign lenders.

Thereby, some calculations show us that, at a reasonable level of debt. Further borrowing would be expected to have a positive effect on economic growth. Others claim that large accumulated debt stocks may be a barrier to growth. Both these considerations combined together imply that debt is likely to have a neutral effect on growth.

Although the "over hang" theory cannot provide an implicit overview of external debt impact over economic growth, we can analyze the Debt "Laffer Curve" (see fig. 1). As the peak of the Debt "Laffer Curve" shows us the point at which rising debt stocks begin acting as tax on investment or other activities upfront costs in exchange for future investments, the peak also can be the point at which the debt begins to have a negative marginal impact on growth.

The external debt is in a tight relationship with the economic growth. To prove this, we will use several analyses of various debt indicators that take into account the fact that a significant part of the external debt is narrowed at an interest rate below the market rate. It is important because most studies considered debt ratios, such as exports to GDP in nominal terms, meaning that the actual amount they will repay in the future is less than the face value of the debt. To particularly analyze the debt overhang effect with the help of the debt indicators, it is also included the ratio of debt service to exports to control for any displacement effects arising from resources spent on debt service instead of investment or growth strengthening of domestic spending. The debt has indeed an inverted $U$ curve with the growth. When countries open up to foreign markets and start borrowing, the effect on growth is likely to be positive from start. As debt ratio increases, eventually additional debt arises which slows the growth even though the overall debt level continues to provide a positive contribution towards growth. Thus, the peak can be considered as the maximum level of debt. Afterwards the debt goes below zero and creates a negative effect towards growth (see fig. 1).

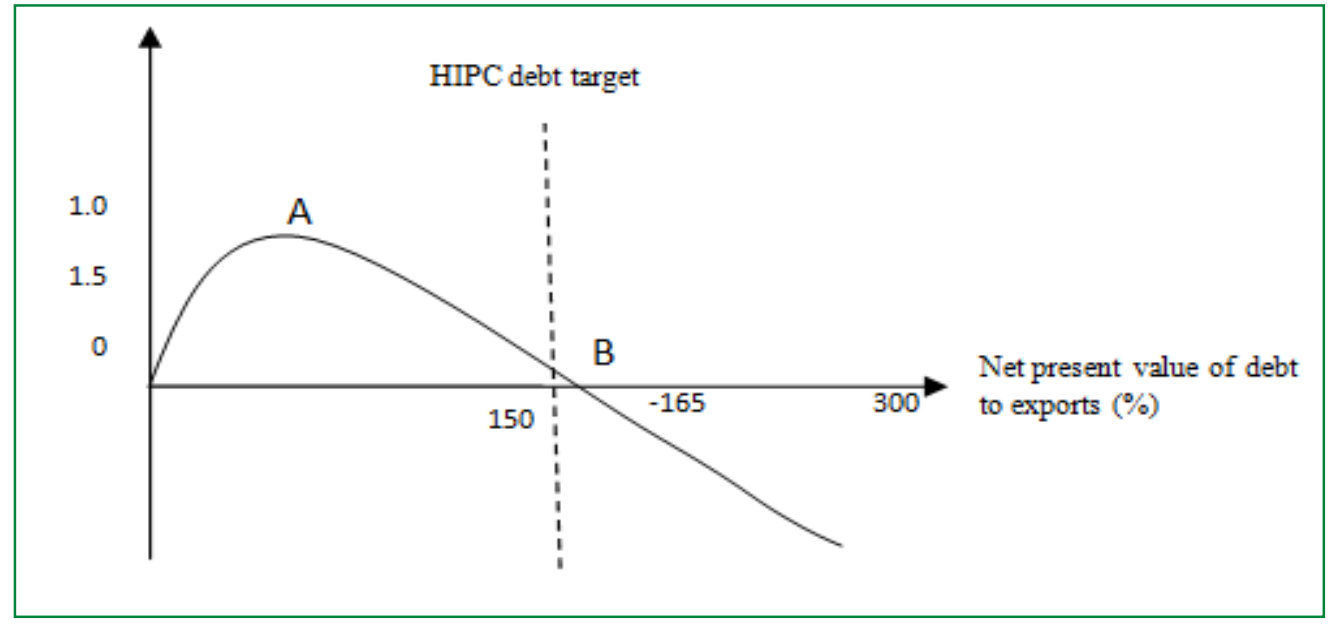

Figure 1. Debt Thresholds

Source: Made by authors in base of [10, PATILLO, C., RICCI, L., 2002]. 
By analyzing the fig. 1, we can notice two critical points. The one where we can identify that at the point $B$, the overall contribution of debt toward growth becomes negative at 160-170 percent of exports and 35-40 percent of GDP. The marginal impact becomes negative at about half of these levels. In particular, it is interesting to denote that countries which benefit from concessional lending are those already which have excessive indebtedness.

The ratio of External debt to GDP is a structural factor influenced by different indicators: the size of the country, the level of economic development and level of economic and financial integration. Countries that are less developed and didn't participate in the globalization or in integration programs have the lowest levels of this indicator. Usually, the critical value of this indicator is at $80 \%$. With the help of this indicator, we can classify the countries in three different categories approved by the World Bank $[2,2000]$ :

$>$ less indebted countries - TED/GDP $\leq 48 \%$;

$>$ moderately indebted countries $-48 \% \leq \mathrm{TED} / \mathrm{GDP} \leq 80 \%$;

$>$ highly indebted countries - TED/GDP $\geq 80 \%$.

For this indicator is very important the marginal rate of debt growth in relation to the rate of growth of Gross Domestic Product. For timely servicing of external debt economic growth rate should be higher than the growth rate of external debt in the current year.

If the economy grows slowly, the government will have to implement some serious adjustments. Whether this really leads to inflation, this depends very much on the monetary policy response. As much as the central bank will maintain the price stability as an objective, any increase of the borrowing will require fiscal adjustments. The relationship between the fiscal and monetary policy is very strongly bounded. This bond describes the relationship explains the long term interest burden and the primary surplus that has to be gathered if the real interest rate is higher than the real economic growth rate. Differently, solvency would always be present. To remove the sovereign default, the interest problem has to be covered by government surpluses gathered in the future. Any increases in the debt ratio, for example an increase in the ratio of the interest rate to the economic growth, will require adjustments, either in the form of higher taxes or reducing the total spending of the country.

The external debt has also an impact on the central banks. If the external debt will grow constantly, the central bank will have to increase the monetary supplies, the monetary base and the level of total reserves also in a relationship with a constant increase of the inflation rate. This process will lead to an increase in revenue from non-interest bearing money creation. Such a shift in policy will be inevitable in the future is enough to lead to an increase in the price level. The real gains from an increase in the inflation rate are rather limited: Revenues generated from non-interest bearing money creation has only a small part from the total revenues of the country. In addition to the idea provided above, an increase in the price level will also decrease the demand for the central bank money.

The price stability can have a significant impact on the economy in the long run. As long as the participants count on price stability, the nominal and real interest rate will also remain low, even if the inflation is quiet high, it will make the external debt manageable for the government. However, high inflation is expected to persist and nominal interest rates will rise sharply because the financial market asks a premium on the risk of asset devaluation through inflation, the high real interest burden can lead to solvency jeopardy. The pressure of the monetary shift to an inflationary policy mounts will lead to an increase in the government's debt ratio.

An inflow of the capital, regardless of where it comes from, will have one or more of the following effects: ${ }^{1}$

$>$ Increasing of the level of foreign investment;

$>$ Increasing of the capacity of obtaining the foreign currency by the respective country, meaning the increasing of the exports or reducing of the imports by means of appropriate investments;

$>$ Incorporation into the investments that do not directly increase the ability to obtain currency (example: in construction);

${ }^{1}$ Băcescu-Cărbunariu Angelica; Condruz-Băcescu Monica, Dependența riscului de ţară față de nivelul datoriei externe, Revista Română de Statistică, Nr.10/2012 
Financing of the speculative activities such as property and stock (including imported stocks);

Offsetting of the private capital outflows due to the political fears or monetary speculation;

Increasing for the government, of the opportunities to avoid the major economic policy transformations such as reducing domestic demand, liberalizing domestic capital markets, encouraging domestic savings or reducing budget deficits;

$>$ Supporting of the consumer spending for medium-sized classes, which are more demanding for imported goods;

$>$ Creating of the sources for military spending;

$>$ Provision of the project or of the other highly profitable businesses that are legally or otherwise intended for government supporters.

To a lesser extent, in most of the countries, we observe a combination of the presented effects. Extreme care should be taken in structuring of the external debt, whether it be its maturity, the currency of the loan or the interest rate. A wrong structure of the external debt is perhaps the most important factor in triggering or accentuation of an economic crisis. Moldova

II. The external debt: a generator of economic crisis or economic solution in the Republic

The Republic of Moldova, as well as other states, call to the foreign loans when domestic savings are insufficient to finance the national consumption and investment. External credits allow the imports to exceed the exports, leading to budget deficit financing and thus delaying important investment projects.

External credits contribute to the acceleration of economic growth, but it is not to be neglected that the country must repay the contracted loans and the related interest.

It is very important for our country to determine the optimal level of indebtedness that the economy can bear. That is why the external debt should be contracted in strict accordance with the needs of the economy, and borrowed loans should consider its reimbursement capacities to avoid the liquidity or solvency crisis.

The external debt of the Republic of Moldova registered an upward trend during the analyzed period, namely an increase from 6 463,89 million USD in 2014 to 7 464,65 million USD in 2018 (see fig. 2).

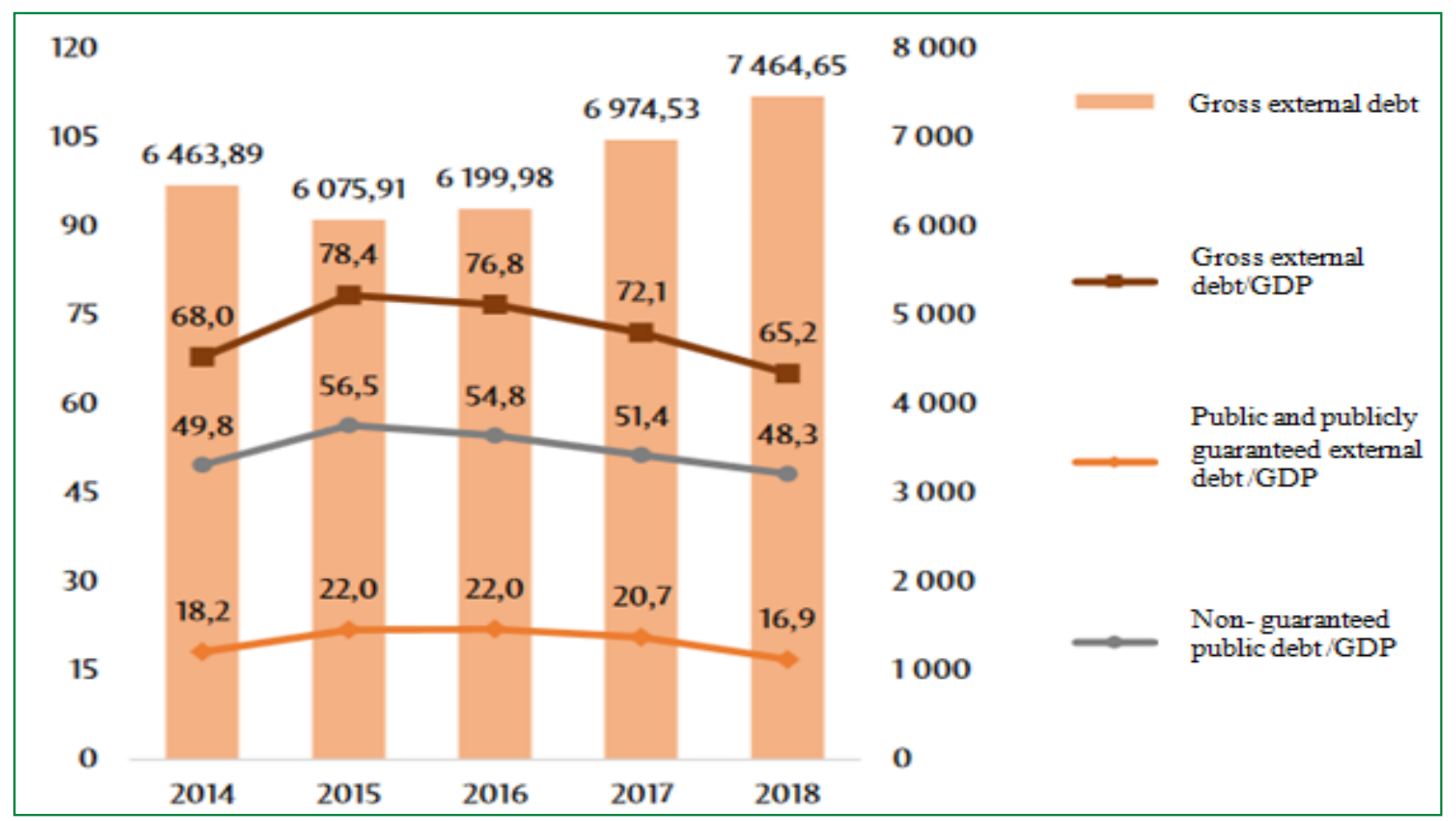

Figure 2. Gross external debt in dynamics, in million USD and \%

Source: In base of data retrieved from www.bnm.org 
The gross external debt of the Republic of Moldova consisted 65,2 \% of the total GDP at the end of 2018, compared with the ratio of $72,1 \%$ in the previous year. If analyzing the evolution of the external debt of the Rep. Moldova, we observe that it started to increase since 2006 followed by a sharp drop in 2008, afterwards rocketed up the next year to 78.82\% from the total GDP [3, IORDACHI, V., CIOBU, S., 2019]. The rate remained practically constant during the years. The highest rate of external debt towards GDP we can notice at the end of 2015, 78,4 \% of the total GDP which is high rate, and as discussed above, we can firmly say that Moldova is a highly indebted country.

The external debt of the Republic of Moldova cannot be considered huge that will lead to an economic crisis. Still, it is above the external debt sustainability level and it can be carefully managed in order to avoid unpleasant economic situations and also budgetary deficits.

To service the external state debt in 2017, the amount of 91,1 million USD (which is the equivalent of 1687,6 million lei) was spent, or with 21,5 million USD $(+31,0 \%)$ more than in 2016 (see table 1). Of the total amount of the expenses destined to service the external state debt, 71,7 million USD (the equivalent of 1329,7 million Lei) constitutes the reimbursement of the principal amounts and 19,4 million USD (the equivalent of 357.9 million lei) - the service of external state debt, which includes the payment of interest and related commissions. Compared to 2016, the servicing of the external state debt registered an increase both at the repayment of the principal $(+16,4$ million USD/ $+29,7 \%)$ and at the payment of the related interests $(+5,1$ million USD $/+35,9 \%)[5,2018]$.

Table 1

Evolution of expenditures for servicing the external state debt in 2015-2017, mil. Lei

\begin{tabular}{|l|c|c|c|c|}
\hline \multicolumn{1}{|c|}{ Year } & $\mathbf{2 0 1 5}$ & $\mathbf{2 0 1 6}$ & $\mathbf{2 0 1 7}$ & $\begin{array}{c}\text { Deviations, 2017 } \\
\text { compared to 2016 }\end{array}$ \\
\hline \multicolumn{1}{|c|}{1} & 2 & 3 & 4 & $5=4-3$ \\
\hline $\begin{array}{l}\text { Servicing the external state debt, } \\
\text { out of which: }\end{array}$ & $\mathbf{9 7 4 , 0}$ & $\mathbf{1 3 9 2 , 0}$ & $\mathbf{1 6 8 7 , 6}$ & $\mathbf{2 9 5 , 6}$ \\
\hline Repayment of principal amount & 724,3 & 1107,3 & 1329,7 & 222,4 \\
\hline $\begin{array}{l}\text { Payment of interest and } \\
\text { commissions }\end{array}$ & 249,7 & 284,6 & 357,9 & $\mathbf{7 3 , 3}$ \\
\hline State debt service growth rate,\% & $+76,3$ & $+67,5$ & $+10,4$ & $\mathrm{x}$ \\
\hline GDP growth rate, \% & $+9,4$ & $+10,5$ & $+11,1$ & $\mathrm{x}$ \\
\hline $\begin{array}{l}\text { State budget expenditures growth } \\
\text { rate, \% }\end{array}$ & $+2,6$ & $+7,3$ & $+9,9$ & $\mathrm{x}$ \\
\hline
\end{tabular}

Source: Decision nr. 25 from 28.05.2018 on the Report on management performance audit of the public sector debt in 2017 [online]. Available on:

http://lex.justice.md/index.php?action=view\&view=doc\&lang=1\&id=376291.

The summary of the expenditures intended for servicing the external state debt in the years 2015-2017 is presented in table 2 .

Table 2

Service of the external state debt in 2015-2017

\begin{tabular}{|c|c|c|c|c|c|c|}
\hline \multirow{2}{*}{ Year } & \multicolumn{2}{|c|}{ Total payed } & \multicolumn{2}{c|}{$\begin{array}{c}\text { Reimbursement of the } \\
\text { principal }\end{array}$} & \multicolumn{2}{c|}{$\begin{array}{c}\text { Payment of interest and } \\
\text { commissions }\end{array}$} \\
\cline { 2 - 7 } & mil. USD & mil. Lei & mil. USD & mil. Lei & mil. USD & mil. Lei \\
\hline 2017 & 91,1 & 1687,6 & 71,7 & 1329,7 & 19,4 & 357,9 \\
\hline 2016 & 69,6 & 1392,0 & 55,3 & 1107,3 & 14,3 & 284,6 \\
\hline 2015 & 51,8 & 974,0 & 38,5 & 724,3 & 13,3 & 249,7 \\
\hline
\end{tabular}

Source: Decision nr. 25 from 28.05.2018 on the Report on management performance audit of the public sector debt in 2017 [online]. Available on:

http://lex.justice.md/index.php?action=view\&view=doc\&lang=1\&id=376291.

The increase of the expenses for servicing the external state debt is caused by the increase of the payments destined for the repayment of the principal amount, as well as by the beginning of the 
repayment of the loan (tranche 3) granted by the IMF to support the budget in 2010 (76,2 million Lei), of the loan (tranche 1) granted by Romania in 2015 (158,0 million lei) and the loan (tranche 3 ) granted by the EIB for the implementation of the project "European Roads" (11,2 million lei).

When developing countries pay their interest rates and maturity rates on contracted loans, they often sacrifice the development of the education or health systems, economic growth and raising the standard of living of citizens. It is essential for the borrowing country that contracted and used external loans contribute to the development and modernization of the economy and investment in infrastructure and not to increase of consumption.

The financial resources should flow from the developed countries to the developing ones, but it is more and more obvious that this flow has been reversed due to the increasing amounts due to the repayments of credits contracted in the previous periods. This makes it difficult for developing countries to show upward growth trends and reduce the poverty.

The foreign loans allow the Republic of Moldova's economy to invest and consume beyond its domestic capacity, and allow the capital formation to be funded from both internal resources and resource-attracting by countries with the surplus of the capital. The external lending can lead to a faster economic growth, allowing more substantial investment to be funded, and mobilizing the resources available to the country, while giving it a more reserved, prudent and even more efficient use. They do not contribute to boosting of the economic growth as they are used to fund nonproductive activities or to counterbalance of the excessive capital exports. In this case, these loans could even exacerbate the pressures on budgetary and balance-of-payments operations.

The idea that should govern the realistic appreciation of the external debt of the Republic of Moldova is, as with other economic processes, the reporting of the external debt costs to the advantages resulting from the foreign capital use or, in other words, the reporting of difficulties arising from the external debt service to the consolidation of the market economy.

A country's external indebtedness is a natural transaction that confers on domestic or foreign economic agents the realization of mutually beneficial inter-temporal arbitrages that a closed economy cannot offer. Although they are natural and add to the efficiency of the economic system, however, the capital flows can lead to a crisis of indebtedness, considering that they create problems on the one hand and solve them on another hand.

We believe that not the existence of the external debt is a problem for the economy of the Republic of Moldova, but its size, currency structure and the interest rates; if the contracted debts record very high levels, their costs can become extremely high, both economically and socially, culminating in the outbreak of a foreign debt crisis.

Moldova's risk of debt distress remains low, in the line of year 2017. All external indicators for public debt remain well below the debt threshold under the baseline, standard bound tests, and alternative scenarios. Although, as Moldova is most sensible to exchange rates depreciation, and as there was a sudden increase in other debt creating flows, Moldova's general public debt dynamics are projected to remain on a normal path under the baseline scenarios and also under the threshold. Nonetheless, Moldova needs careful and firm fiscal policy, and has to implement and improve its structural reforms to ensure the debt sustainability. Because of that Moldova is sensible to exogenous developments, and banking crisis, debt sustainability is strictly based on sound macroeconomic management and continuing progress on institutional and structural issues that would help to open the economy's growth ability and reduce its vulnerability to shocks. In addition, the limited development of domestic debt market poses financial risk, considering the country's necessity to development and significant dependence on foreign aid in the form of grants and concessional loans. The country has to implement several policies and put some effort to lengthen the average maturity of the domestic debt and sink the secondary market.

In the medium term the tendency of covering the state budget balance (deficit) predominantly from external sources prevails. This development reveals the considerable dependence of the Republic of Moldova on external creditors and, implicitly, the financial and structural conditions for accessing foreign funds.

In the period 2018-2020 it is estimated that the Government will benefit from foreign state borrowing, which will be directed, on average, to $22,9 \%$ for the budget support, and for the 
financing of the investment projects - of about $77,1 \%$. At the same time, foreign state loans will be granted almost entirely by multilateral institutions during this period. The medium-term structure of external financing by category of instruments is presented in table 3 .

Table 3

External financing during the years 2018-2020, according to the baseline scenario

\begin{tabular}{|l|c|c|c|c|}
\hline \multicolumn{1}{|c|}{ Indicators } & U/M & $\mathbf{2 0 1 8}$ & $\mathbf{2 0 1 9}$ & $\mathbf{2 0 2 0}$ \\
\hline External debt financing including: & \% from GDP & $4.8 \%$ & $4.6 \%$ & $3.3 \%$ \\
\hline $\begin{array}{l}\text { Loans from multilateral creditors at } \\
\text { concessional terms }\end{array}$ & \% from total & $1.8 \%$ & $1.5 \%$ & $1.4 \%$ \\
\hline $\begin{array}{l}\text { Loans from multilateral creditors at } \\
\text { semi concessional terms }\end{array}$ & \% from total & $38.3 \%$ & $38.4 \%$ & $32.8 \%$ \\
\hline $\begin{array}{l}\text { Loans from multilateral lenders with } \\
\text { variable interest rate }\end{array}$ & \% from total & $59.9 \%$ & $60.1 \%$ & $65.8 \%$ \\
\hline $\begin{array}{l}\text { Loans from bilateral creditors with } \\
\text { fixed interest rate }\end{array}$ & \% from total & $0.1 \%$ & $0.0 \%$ & $0.0 \%$ \\
\hline
\end{tabular}

Source: Elaborated by author based on Interactive Database of Government of Moldova [online]. Available on: http://lex.justice.md/UserFiles/File/2018/mo7-17md/program_1148.docx.

The structure of creditors of forecasted sources of external financing reveals the most important creditors for the period 2018-2020, as follows:

$>$ European Investment Bank - 30,6\%;

$>$ World Bank Group - 28,9\%;

$>$ European Bank for Reconstruction and Development - 23,3\%;

$>$ European Commission - 5,6\%;

$>$ Council of Europe Development Bank - 5,6\%;

$>$ International Monetary Fund - 4,3\%;

$>$ International Fund for Agricultural Development - 1,6\%;

Government of Poland - 0,02\%.

From the previous years, taking into account the constraints imposed by the local financial market, the Ministry of Finance intends to initiate a transition process, which will start with the implementation of the S1 with medium-term orientation towards: the possibility of extending the financing from the creditors bilateral agreements in order to reduce the impact of reducing external financing on concessional and semi-concessional terms; developing new instruments to be issued on the domestic market, focusing on expanding their maturity and analyzing the possibility of issuance of state securities on international markets, thus increasing the attractiveness of the SS local market but taking into account the implications of the exchange rate in this respect.

At the same time, the Ministry of Finance will continue to maintain a flexible approach to the process of financing the state budget deficit (deficit) on the local market, in order to ensure the predictability and transparency of the state securities offer, in order to be able to react promptly to possible changes in the market trends and investor behavior $[8,2017]$.

There are other risks which can significantly influence the economy of the country and also affect negatively the external debt of the country. Here we can list some potential risks that can arise in the long run in the development process of the country:

$>$ uncertainty about disbursements from official creditors, taking into account the country's dependence on external development partners;

$>$ failure to implement the originally planned deficit target in the budget;

$>$ global uncertainty about the influence of the monetary policy conduct of the main central banks of the world (the ECB and the Fed) and the consequences of the referendum in the UK;

$>$ increase of the inflation rate and tightening of the monetary policy of the National Bank of Moldova;

$>$ depreciation of the official currency exchange rate of the national currency relative to the main currencies in which the external debt is denominated; 
$>$ political instability and unpredictability of political decisions;

$>$ diminishing national and international credibility for SS investors;

$>$ operational risk, and other risks that can arise during the years.

All the above mentioned risks can have a negative influence on the national economy of the Republic of Moldova. These risks can lead to major problems in the country, for example the failure to implement the deficit objectives planned from the start can lead to additional unplanned costs and also will lead to external debt growth. The country will have to find other sources in order to cover the deficit gap. In order to avoid such situations or to deal correctly with this risk, the country has to improve the fiscal policy and to analyze it in correlation with the external debt of the country. Inefficient fiscal policies can make it difficult to achieve the planned objectives for the upcoming year and also will cause additional expenses in order to cover the debts. The government has to make a strict relationship between the external debt and the correct administration of the government's liquid assets.

In order to deal with the problem of official exchange rate depreciation in relation with the main currencies in which the external debt is denominated, the government has to increase the share of net financing in national currency, which would facilitate the reduction of foreign exchange exposure, while taking into account the absorption capacity of the domestic market and, in general, the demand for debt instruments, expressed in MDL. The government has also to apply provisions to the estimate of the government debt balance and its service costs in the event of significant fluctuations in the official currency of the domestic currency.

Republic of Moldova has to make big changes in the external debt management in order to at least maintain the external debt and not to make it grow higher and to be ready to deal with potential risks that can arise during the time. If the diminishing national and international credibility for SS investors will arise, it will cause huge troubles for the country. First of all, it will lead to a decrease in the SS because the investors will lose their desire to invest. In such a way, the country will not be able to finance its project and also to cover its deficit gap from the existent sources of funding from the local market. It will have a huge impact on the economic growth of the country and it will also lead to an increase in the public debt of the country.

CONCLUSIONS. As the external debt of the Republic of Moldova cannot be considered huge that will lead to an economic crisis. Still, it is above the external debt sustainability level and it should be carefully managed in order to avoid unpleasant economic situations and budgetary deficits. The country has to analyze carefully its investment portfolio for the planned projects and also to compact the projects by giving priority to the most important projects for the national economy. It will help the government to repay the existing debts from their revenues. Also the government has to improve their SS securities market, the primary and the secondary market in order to diversify the potential sources of finance. The government can transform the local financial market into a stable source of funding for budgeting and also it can diversify the domestic debt instruments and increasing their attractiveness. It is not necessary only to issue the securities only on the local market, but to have positive results, the government has to analyze the opportunity and take the necessary actions to enter the international financial markets by issuing bonds in foreign currency. The government has to supervise regularly the sustainability indicators of the state debt so that their dynamics will be within acceptable limits in the medium term and also to analyze the financial conditions of the newly borrowed external loans, the most optimal variant in terms of maturity of the loan and interest rate at the negotiation stage, for each individual loan.

\section{REFERENCES}

1. BĂCESCU-CĂRBUNARIU, A., CONDRUZ-BĂCESCU, M. Dependenţa riscului de ţară faţă de nivelul datoriei externe. In: Revista Română de Statistică. 2012, nr. 10, pp. 57-62. [Accesat 30.09.2019]. Disponibil: http://www.revistadestatistica.ro/wpcontent/uploads/2014/02/RRS_10_2012_A4_ro.pdf

2. Guidelines for Public Debt Management. International Monetary Fund, World Bank. 2000, march 21. [Accesat 30.09.2019]. Disponibil: https://www.imf.org/external/np/mae/pdebt/2000/eng/guide.pdf 
3. IORDACHI, V., CIOBU, S. Sovereign external debt management in the Republic of Moldova challenges and sollutions. In: The journal Contemporary Economy. 2019, vol. 4, issue 2, pp. 92102. ISSN 2537-4222.

4. KRUGMAN, P. Financing vs. forgiving a debt overhang. In: Journal of development Economics. 1988, vol. 29 (3), pp. 253-268. ISSN 0304-3878.

5. Hotătîre cu privire la Raportul auditului performanței managementului datoriei sectorului public în anul 2017: nr. 25 din 28.05.2018. In: Monitorul Oficial al Republicii Moldova. 2018, nr. 246-254, art. 25. [Accesat 13.10.2019]. Disponibil:

http://lex.justice.md/index.php?action=view\&view=doc\&lang=1\&id=376291

6. Hotarare cu privire la unele măsuri de executare a Legii nr. 419-XVI din 22 decembrie $2006 \mathrm{cu}$ privire la datoria sectorului public, garanțiile de stat și recreditarea de stat: nr. 1136 din 18.10.2007. In: Monitorul Oficial al Republicii Moldova. 2007, nr. 175-177, art. 1216. [Accesat 15.05.2019]. Disponibil: http://lex.justice.md/md/325680/

7. Lege cu privire la datoria publică, garanțiile de stat și recreditarea de stat: nr. 419 din 22.12.2006. In: Monitorul Oficial al Republicii Moldova. 2007, nr. 32-35, art. 114. [Accesat 15.05.2019]. Disponibil: http://lex.justice.md/viewdoc.php?action=view\&view=doc\&id=333420\&lang=1

8. Managementul datoriei de stat pe termen mediu (2018-2020): program. 2017. [Accesat 15.05.2019]. Disponibil: http://lex.justice.md/UserFiles/File/2018/mo7$17 \mathrm{md} /$ program_1148.docx

9. Notă cu privire la prognoza principalilor indicatori macroeconomici pentru anii 2020-2022. [Accesat 15.05.2019]. Disponibil: https://mei.gov.md/sites/default/files/document/attachments/nota_prognoza_macroeconomi ca.pdf

10. PATILLO, C., RICCI, L. External Debt and Growth. In: Finance and Development. 2002, vol. 39, no. 2. [Accesat 15.05.2019]. Disponibil:

http://www.imf.org/external/pubs/ft/fandd/2002/06/pattillo.htm

\section{ARTICLE HISTORY}

Received 04 November 2019

Accepted 02 December 2019 


\title{
THE RISK OF FINANCIAL NETWORKS \\ IN THE CONTEXT OF CURRENT CHALLENGES
}

\author{
Otilia MANTA1, PhD in Economics \\ Center for Financial and Monetary Research \\ „Victor Slavescu”, Romanian Academy
}

DOI: https://doi.org/10.36004/nier.es.2019.2-04

JEL Classification: F17, G15, G23, G29, 016

UDC: 330.131.7:336]:004

\section{ABSTRACT}

In the current context of the redefinition of financial markets due to the challenges generated by the multi-polarity phenomenon, virtual space becomes the main trading place for financial products, and our role as a researcher is to identify new financial instruments appropriate to this reality, which is why we consider that a market trend financial is that of a new network architecture in the virtual financial space based on nodes of financial interference. Moreover, financial space is a monetary representation of all other areas that can be identified and defined in society, especially in the economy, and can be considered as a set of specific financial interconnections with defining characteristics that determine them. Along with the profound changes in the interconnection of the socio-economic entities, using the new information channels, more and more often in the discussions of the specialists and not only a number of monetary issues are debated, in its virtual aspect, respectively the financial risks related to the virtual space, as well as the degree of "mastery" of information networks. In this context, in this paper we will try to make a series of contributions on how this financial space is designed - as a complex network with an adequate degree of risk.

Keywords: finance, financial network, digitization, financial risk and sustainability.

În contextul actual al redefinirii piețelor financiare urmare a provocărilor generate de fenomenul multipolaritate, spațiul virtual devine principalul loc de tranzacționare al produselor financiare, iar rolul nostru de cercetător este să identificăm noi instrumente financiare adecvate acestei realități, motiv pentru care considerăm că o tendință a piețelor financiare este aceea ca a unei noi arhitecturi de tip rețea din spațiul financiar virtual, bazată pe noduri de interferență financiară. Mai mult, spațiul financiar este o reprezentare monetară a tuturor celorlalte domenii care pot fi identificate și definite în societate, în special în economie, și pot fi considerate ca un set de interconexiuni financiare specifice cu caracteristici definitorii care le delimitează. Alături de schimbările profunde în interconectarea entităților socio-economice, folosind noile canale de informare, din ce în ce mai des în discuțiile specialiștilor și nu numai se dezbat o serie de probleme monetare, în aspectul său virtual, respectiv riscurile financiare legate de spațiul virtual, precum și gradul de „stăpânire” al rețelelor de informații. În acest context, în această lucrare vom încerca să aducem o serie de contribuții asupra modului în care este conceput acest spațiu financiar - ca o rețea complexă cu un grad adecvat de risc.

Cuvinte-cheie: finanțe, rețea financiară, digitalizare, risc financiar și durabilitate.

В нынешнем контексте переопределения финансовых рынков из-за проблем, порождаемых феноменом многополярности, виртуальное пространство становится основным местом торговли финансовыми продуктами, и наша роль как исследователя заключается в выявлении новых финансовых инструментов, соответствующих этой реальности, поэтому мы считаем, что тенденция финансовых рынков - это новая сетевая архитектура в виртуальном финансовом пространстве, основанная на узлах финансового вмешательства. Кроме того, финансовое пространство представляет собой денежное представление всех других областей, которые могут быть выявлены и определены в обществе, особенно вэкономике, и могут рассматриваться как набор

1 C Otilia MANTA, otilia.manta@rgic.ro, otilia.manta@icfm.ro

No. 2 / 2019 
конкретных финансовых взаимосвязей с определяющими их характеристиками. Наряду с глубокими изменениями во взаимосвязи социально-экономических субъектов, использующих новые информационные каналы, все чаще и чаще в дискуссиях специалистов обсуждается не только ряд денежных вопросов, в виртуальном аспекте, соответственно, финансовые риски, связанные с виртуальным пространством, а также степень «владения» информационными сетями. В этом контексте, в статье рассматривается устройство этого финансового пространства, как сложной сети с адекватной степенью риска.

Ключевые слова: финансы, финансовая сеть, оцифровка, финансовый риск и устойчивость.

INTRODUCTION. The financial market is a network of relationships made up of institutions, flows and instruments that ensure the transfer of financial assets and goods (currency and its substitutes) from one economic subject to another, which is realized, directly or indirectly, punctually or cumulatively.

The created financial flows between economic subjects (accounting organizations, institutions) forms financial circuits where the currency can take different forms of financial assets between two consecutive exchanges (sale or purchase) of commodity. Financial circuits, which constitute money transfer channels, carry the currency of payment, saving currency, placement currency, speculative currency, reserve currency, hedging currency, etc., by activating, balancing, valuing, distributing, multiplying the currency, creating a multiplicity and diversity of financial markets, interconnected and integrated into a network.

The main working hypotheses in this article are:

I1. The financial circuit may be represented in the network;

I2. The financial markets within the network are integrated;

I3. Flawless links between risks and performance in financial networks are created.

Relating from the first working hypothesis the financial circuit can be represented as follows:

where:

$$
S_{1} \wedge A_{1} \wedge A_{2} \wedge A_{3} \wedge A_{4} \wedge S_{2}
$$

S1, S2 - commodity-money exchange;

$\mathrm{A} 1, \mathrm{~A} 2, \mathrm{~A} 3, \mathrm{~A} 4$ - currency flows as a financial asset;

The financial markets within the network are integrated, ie they include and intersect, reunite and influence, forming a functional unit through a variety of forms.

Financial Markets include the following forms:

- the settlement, payment and payment markets;

- the credit market, which transfers currency by transformation and monetary creation;

- the deposit market, collection by concentration and depersonalization of the currency.

These three forms (segments, components) form the bank market, in its original meaning.

- the money market, with its defining component, the interbank market, to which the central bank, administered by the central bank, is transferred, the currency that forms the basis (primary source) of financial flows;

- the financial securities market, ie debts (liabilities, commitments) written in short-term maturity $(<1$ year);

- the securities, stocks and bonds market, with long-term maturity, called the capital market;

- the hedging market, derivatives that represent hedging contracts;

- the currency market, on which national currencies (currencies) are changed.

These eight forms of the financial market can be found, depending on the nature and content of financial instruments (support of financial assets, currency), in a diversity of hypostases, the financial market segmenting and assimilation, customization and uniformity -they, forming, as I said, a unity in diversity.

\section{RESEARCH METHODOLOGY}

As research methodology, we used classical observation and examination instruments, research methods based on the basic principles of scientific research, namely: "competence, objectivity, truth, methodical, demonstration, correlation, evaluation of results, utility and psychomoral "(Ristea and Franc, 2013). Procedures based on factual analysis, intensive documentation at 
the level of domestic and international literature, using the databases and the scientific material existing in the endowment of libraries of specific institutes in Romania and internationally, have been used. The methodology of the paper has as a direct instrument the collection of data and information from the literature and from the existing practice in public and private institutions, but especially scientific articles published on specialized research networks (ResearchGate, Academia.edu, etc.), published articles in various journals, relevant books in the field of reference, legislation, analyzes and studies, official documents, and interactive database of the National Bank of Romania, other relevant sources identified in the libraries: CCFM, Romanian Academy, INCE, IEN, BNR, National Library, INS, etc. Moreover, we analyzed the documents using the comparative, analytical, descriptive method, the nonparticipative and participatory observation, the use of a set of informational sources, the collection of financial data in the established databases. Also, the paper was based on annual reports, publications, consolidated statistical data provided by the European Commission, the National Bank of Romania, the European Central Bank (ECB), the International Settlement Bank (BRI), the European Commission, OECD, published annually. have been processed in order to provide an overall and analytical picture of the most important changes taking place in the European Union as a whole, but also globally - considered to be representative of the understanding of the phenomena studied, and especially in Romania.

\section{RESEARCH RESULTS}

The financial space is dual, presenting two often contradictory hypostases: the totality of entities, channels, stocks and collection streams, on the one hand, and all entities, channels, stocks and placement flows on another hand. In this context, we propose to analyze the components of the financial network and a better delimitation of the risks that may arise in such types of networks.

Any company, in order to achieve its short, medium or long term goals, interacts with its social, economic, natural environment. From a financial point of view, the company's relationship with its environment can be formalized by appealing to the concept of financial network. In this way, a financial structure at micro, meso or macroeconomic level can be reflected, identifying the interconnections between autonomous entities, recognized and identified legally, economically and socially. On the other hand, the financial space is a monetary representation of all other areas that can be identified and defined in society, particularly in the economy, and can be considered as a set of specific financial interconnections with defining features that delimit them.

Network risk (RRT) takes on concrete forms of action, manifestations, typically determined by the characteristics of the network that are affected by the decoupling, distortion, phasing out, distortion, weakening of the strength of a financial network feature. Obviously, these forms refer to the radiant impact of the institutional characteristic of the network, embodied in norms, bodies, rules, structures, etc. on the interactive features of the network. The institutional grid of the network is the force, the ability of the interactive feature of the network to negatively influence the performance of the components ${ }^{1}$.

Based on these considerations, the global risk of financial networks needs to be assessed in the current context of challenges in terms of the functionality of the financial network principle.

The complex relationship in which the network risk acts on the performance, the goals, the functionalities and the potentialities of the network is presented in figure 1, in the form of an impulse relathionship, justification of working hypothesis 3, respectively flawless links between risks and performance in financial networks.

\footnotetext{
1 Mihail D., Manta O. (2017): Architecture of Flows and Financial Stocks - Mechanism and Transmission Channels, Flow, Transmitters and Receivers, published in Advances in Intelligent Systems Research, volume 132, Atlantis Press.
} 


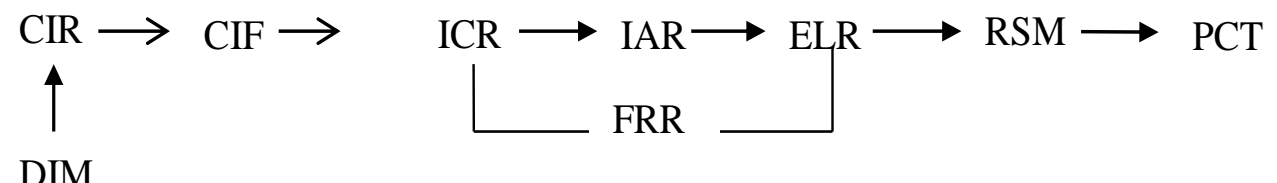

Figure 1. Impulse relationships between risks and performance

The meaning of the symbols is the following:

- DIM = institutional deficiencies of the financial network;

- $\mathrm{CIR}=$ the institutional feature of the network;

- $\mathrm{CIF}=$ interactive features of the network;

- ICR = network interconnections;

- IAR = network interactions (interactive flows;

- ELR = network elements;

- FRR = network risk forms;

- $\mathrm{RSM}=$ risks specific to the financial network;

- $\mathrm{PCT}=$ losses and costs.

The forms of network risk are as follows:

- The credibility risk is the essential form of risk of the financial network, mitigating or distorting the trust of the economic subjects in the currency, financial instruments, financial-monetary institutions, due to the malfunctions, directly or indirectly induced by contagion, immediate or delayed, with a time lag, all the specific risks and, first, the risk of depreciation of the currency.

Financial networks are irreducible to purely economic reasoning centered on earningsoriented economic interest, money transactions, operations and financial flows, relying on the trust of entities, economic subjects in the financial network, the transaction network, the fiduciary dimension being vital to the reproducibility of networks and for their continuity over time. Trust is an integral part of maintaining interconnections and interactive financial flows, especially taking into account the uncertainty and complexity of transactions.

Winning economic rationality does not cover the space of confidence in the currency, depending on different factors, economic rationality depending on individual, selfish, competing and confronted interests on the market, while trust is conditioned by coexistence, social, political, cultural, but also economic, trusting reciprocity, while economic rationality involves exclusion through competition (even if the market harmonizes gains through interests).

Trust is an essential property of the coin, an abstract feature of money in general, which does not imply the stability and validity of the concrete forms of the currency, since confidence in the stability and validity of a monetary form, a financial instrument, means trust in institutions and rules, and rules are directly responsible for the administration of this form of currency. In this respect, the nature of the risks involved in financial transactions, in interactive flows, reflects their unique character in the modern world, namely that they are generated by man-made institutions.

It can be argued that the credibility risk is not associated with trust in money as a social institution, but with confidence in social institutions, ie regulations and organizations, which create and administer specific monetary forms, financial instruments traded on the markets.

The credibility risk in the financial system is determined by economic, but especially extraeconomic conditions, the placement of monetary forms in an environment centered on economic rationality, the dependence of financial transactions, the interactivity of the financial network of interests and economic gain distorts and vices the functions of the currency, its transitive potential, the goals of the network, assuring the concrete forms of the coin of improper, adverse and unfavorable finiteities and functionalities. In this respect, speculative or derivative financial forms, as quaternary, forward-looking currencies, are at the same time extreme forms of risk credibility, generating risk, covering it [4, SHAPIRO, Carl et al., 1998].

- Vulnerability risk is a generic risk of the financial network, due to the inadequate, institutionally 
caused, flow characteristics and financial network, such as reliability, complexity, integration, intensity, connectivity, affecting the network as a whole, but differentiated on elements, interconnections and interactions.

Vulnerability expresses the debilitating of the transitive potential of the interactive flows of the network, favoring the emergence of specific risks, such as exchange rate risk, currency depreciation, interest rate risk, market risk, especially through the inadequacy channel and the inactivation channel.

The organizational inconsistency of the financial network, the inconsistency of the financial instruments, the forms of currency in the financial asset hypothesis, the inadequacy of the financial operations, the rigidization and the temporal or dimensional incongruity of the sources and the destinations of the interactive flows are institutional causal factors of the vulnerability of the network, perceived by network participants by diminishing the reliability of flows that may generate liquidity or solvency risk through volatility of asset prices through the juncture of network nodes [12, SUNDARARAJAN, Arun, 2008], i.e. financial institutions or markets, which may ultimately lead to bankruptcy risk and so on.

Institutional causes of monetary network vulnerability may be:

$\checkmark$ a compositional incompleteness of entities, for example the lack of necessary entities;

$\checkmark$ a failure of connections, cumulative or distributive nodes;

$\checkmark$ o lack of functional loop connectors such as guarantee bodies, trade effects, advisory entities, and network loops to ensure the re-circulation of the inactive, temporary pending currency, such as the locked currency;

$\checkmark$ the degradation of operational synapses, such as the transformation of deposits, due to the interactive gap between collection and placement or currency convertibility due to the institutional irrelevance of monetary forms, such as reserves, surpluses, placements.

The risk of vulnerability is therefore, above all, a risk of institutionalization of the financial network and derives from the network's inadequacy to environmental conditions, to its requirements and needs, and in this respect the direct effect of this network risk, the depreciation of the currency in its form - transactional, interactive, currency risk, is associated with the degradation of these conditions, with the relation between the internal and the external environment.

-The risk of de-synchronization is a risk of the flows, of their interconnection in the network, affecting the interactivity of the network, ie its essence, being formally generated by the institutional regulation and organization of the network, and thus by the way of the network implementation, and functionally, i.e. the activities, responsibilities and competences of the constituent entities [5, DIMITRIU, M. et al., 2017].

Desynchronization refers to the occurrence of any disagreement, of any kind, between the network flows, with the following aspects: gaps, gaps, defects and incompatibilities.

Time spans between cash inflows and outflows, between the formation of monetary resources and liquidity, and their use, transforming them into placements, increasing the stagnation of the coin as an inactive currency. If some gaps are necessary for financial transactions and interactions, most are inertial, institutionally determined, often even regulatory, inducing lasting differences, affecting the fluidity of money, circulation, and currency transformation, usually triggering liquidity and capital risks.

Dimensional differences in the capacity and length of flows, but also in the extensibility and intensity of the financial network. If, for example, there is a discrepancy between the capacity and the length of the collection and placement of flows, the risk of de-synchronization can also generate the liquidity risks, as well as the discrepancy between network extensibility and insensitivity, which will primarily affect the effectiveness of the network, causing a risk of financial asymmetry, concentration and rigidisation associated with the insolvency risk of financial entities that, through contagion, can affect the entire network.

Flow deficiencies due to the circuit of the instruments on the flow, the network velocity, these streams often result in blockages, being partly responsible for the occurrence of the risk of network agglutination, with effects on the network interactivity, determining the liquidity and monetary depreciation, as well as the currency risk [1, SUNDARARAJAN, Arun, 2019].

Instrumental incompatibilities manifested by the inadequacy of the financial instruments to achieve certain goals or functionalities of the network, their non-adaptation to the transited currency 
aggregates (locked currency, reserves, savings, equity, hedge funds, etc.), or, generally speaking, the supply of financial and monetary instruments (checks, cash, cards, accounts, etc.) and the demand, and especially the potential, demand, which expresses the need for economics of instruments, perhaps not yet operational, and why not yet unthinkable.

The risk of de-synchronization induces a negative resonance in the network, in the case of an increased dissonance, the network may enter into "trepidation", the generic expression of this situation, the risk of vibration, negative resonance being the fluctuation, the agitation of the exchange rate, the price, the purchasing power of the coin, on a trend of chronic depreciation [2, BELVAUX, Bertrand, 2011].

The institutional causes of this risk are connected and often dependent on economic, social and political causes (unless we consider monetary policy itself an institution), but it is obvious that the way of building its financial network, its architecture, its institutional dimensions and adequacy, contributes significantly to the emergence and maintenance of this risk.

- The agglomeration risk, correlated with the two previous risks, is manifested through the abundance, segregation and concentration of the currency forms and of the financial instruments on flux, in certain areas of the network, by regionalization, polarization and conjucturing, phenomena with different etiologies, institutional inadequacy of the network, creating favorable conditions, especially through the channel of incapacity, for the occurrence of rate, insolvency, and obviously market, price risks, financial assets, currency.

Very often, this network risk is associated with insufficient networking of specific elements of the network, which will provide certain services to the markets and contribute to strengthening its transparent automata, such as:

$\checkmark \quad$ a continuous counting of network flows, highlighting crowded and relatively free routes, for example, the discrepancy between the interbank and the financial or the pay gap, this metering having a potential for selectivity and potential reorientation;

$\checkmark$ functional and operational adaptation of flows to the concrete requirements of interactivity, by setting up network adapters, analogue clearing houses, transforming financial assets and instruments, and forms of currency according to market requirements, making these adapters an integral part of financial markets (such as adapters), liquidity fluidization (factorial adapters), rate compensation (distributive adapters), etc., taking over some of the current market dysfunctions, such as speculative ones, which distorts some of these adaptation attributes, and redesigning the market by integrating it, strengthening its institutional network automation.

$\checkmark$ in an instrumental conversion, trying to achieve this conversiveness interactivity, the market, as it is conceived and established, is not conversational but marginal or improper, I would say, it is forcing little institutional potential of the network. A conversion market, such as the derivatives market, could be constitutively and institutionally made, in fact, anticipating and conditional this conversion, but often in a speculative environment, denaturating the functions of the currency, of monetary forms [9, MANTA, Otilia, 2018].

Managing this network risk is principally a problem of institutionalization and functionally an issue of evaluation and supervision because the flexibility of the currency, its equitable freedom, should also be found in its capitalized, financially instrumental forms, between currency-trust, it gives omniscence to it, and economic judgment, which usually regulates fragmentarily, capital flows, saved money, contradictions, crisis-generating confrontations that partially reflect the existence of this agglomeration risk with speculative openings [10, ECONOMIDES, Nicholas et al., 2006].

- The risk of detachment and polarization is the specific network risk that suffers from three institutional diseases:

$\checkmark$ ignorance, in the sense of disregard or insufficiency of consideration of the environment, due to the institutional endowment, which gives it some form of knowledge and understanding;

$\checkmark$ vanity, not in the anthropomorphic sense, determined primarily by the approach of currency, of monetary forms, in terms of profit-centered economic reasoning, financial entities considering the currency capitalized as a generator of power and not as a binder between the network and the environment, bidders and coin applicants, the bank currency, and its financial form, which produces wealth, denoting for the most part the functions of the coin, perhaps adapting them to distorted forms 
of authentic currency, based on trust; obviously, vanity is reactive, not adaptive, and that is the case of financial crises, often induced by financial entities, banking in the socio-economic ensemble;

$\checkmark$ esoterism, in the sense of the financial sector, especially the banking sector, being hardly accessible to the uninitiated, this disease being landless, from time immemorial, and partly with constitutive justifications and, we could say, ontological. The coin being something very sensitive and omniscient has been called the blood of society, but it has now become a kind of pathology of appearances, a pathology commanded, authentic, original esoteric, original, disappearing, remaining an esotericism of complications, often unnecessarily functional functional diversions mimetic esotericism, but the more sickly and contagious [11, GRANT, Robert M., 2010].

The risk of detachment is manifested by the separation of the financial network from the socioeconomic environment as a whole, from its real markets, including the health, culture, education, financial network, and sometimes it is in the face of the specific evolution of these human areas how to build up the guiding principles of its configuration and architecture, so that posting induces specific risks in the financial network, such as rate and rate, volatility and lack of real coverage, not speculativearbitrary, generating furious crises at the local level, regional, hard-to-absorb, loss-making and environmental costs, but also liquidity risks, ending up with bankruptcy as well as non-financial entities.

The polarization risk highlights the network's tendency to create concetrative poles, financial centers officially represented by the central bank, which, beyond the coordination and regulatory attributes, becomes a market operator in the name of monetary policy, conferring confidence in the currency, in its purchasing power, but also in operative financial centers, which co-ordinates with money, the financial instruments, the power to influence, to intervene, to sometimes unbalance the markets in the "order" to balance them according to already esoteric goals, or at least selective beneficial [6]. Polarization is a phenomenon common to all networks, from mineral, natural to neural and spiritual, but the polarizing institutionalization of the financial network can have perverse, sometimes unpredictable effects, polarization contributing to accentuating network risks, financial network specificities, to the extent in which polarization does not serve the network, the currency, the trust in the currency, exacerbating, for example, the gain orientation, according to economic reasoning.

A significant effect of postponement and polarization risk, a potential and a real effect, is generating specific devastating risks is the unparalleled expansion of the value of financial flows compared to real flows, most financial flows milling down the currencies, obviously for earnings, for the transfer, rarely converted into real, consuming or investment assets [3, BULEY, Taylor, 2009].

\section{CONCLUSIONS}

The five types of network risks developed above do not cover the whole range of risk potential inherent in the financial network, highlighting only their existence, their specificity and relevance in the monetary space, as well as their institutional determinant etiology. At the same time, the above approach wanted to reveal that the credibility risk is paramount, being the generic network risk, the placement of its currency, its forms and instruments, in a space dominated by economic reasoning, centered on interest and gain, credibility in the currency, the ability of the coin to perform its original functions.

Risk Network, the five types of its defined above are generated by both determinants and conditioning, and they generate direct and indirect effects through specific risks network financial risk network is placed in a structure of interdependencies, of direct and mediated influences [5, DIMITRIU, M. et al., 2017].

Financial market infrastructure plays a central role because financial stability is greatly influenced by the environment in which financial intermediaries operate. As there are cultural differences, there are also structural differences between countries. Nations have a diversity between political and economic systems, legal frameworks and tax structures, which play a central role in the development of their financial systems. Those national influences can certainly interact and certainly affect practices and procedures in the regional financial markets.

Risks of financial instability are likely to occur from time to time and therefore formulate a well articulated strategy to address potential financial imbalances should be high on the agenda of central banks and supervisors [11, GRANT, Robert M., 2010]. Such strategies should cover the following areas: A coherent policy framework at the macroeconomic level to ensure the implementation of a coherent 
macroeconomic policy framework [7, BLIND, Knut, 2004], essential for maintaining financial and monetary stability. The framework should be consistent in achieving macroeconomic objectives and should avoid the accumulation of imbalances that may lead to financial instability.

From the point of view of the personal contributions related to the working hypotheses, we consider that the determinant element that leads us to the definition of the financial network is given by the risk of detachment and polarization and that is also the specific risk of the network. Moreover, as mentioned above, the network is placed in a structure of interdependencies, which causes us to reconsider the direct influences on the new architecture of the financial market, these will be the subject of continuity of our research. At the same time, we consider that the working hypotheses are confirmed due to the fact that both I1.the financial circuit may be represented in the network and I2. The financial markets within the network are integrated are determinants for I3. Flawless links between risks and performance in financial networks, and all these lead us to a current integrated and multipolar financial system.

\section{REFERENCES}

1. SUNDARARAJAN, Arun. Network Effects. [Accesat 11.08.2019]. Disponibil: http://oz.stern.nyu.edu/io/network.html

2. BELVAUX, Bertrand. The Development of Social Media: Proposal for a Diffusion Model Incorporating Network Externalities in a Competitive Environment. In: Recherche et Applications en Marketing. 2011, vol. 26 (3), pp. 7-22. ISSN 2051-5707.

3. BULEY, Taylor. How To Value Your Networks. 2009, july 31. [Accesat 11.08.2019]. Disponibil: https://www.forbes.com/2009/07/31/facebook-bill-gates-technology-securitydefcon.html\#1d48d4ee4cea

4. SHAPIRO, Carl, VARIAN, Hal R. Information Rules. Brighton: Havard Business School Press, 1998. ISBN 0-87584-863-X; ISBN 9780875848631.

5. DIMITRIU, M., MANTA, O. Architecture of Flows and Financial Stocks-Mechanism and Transmission Channels, Flow, Transmitters and Receivers. In: Modelling, Simulation and Applied Mathematics: 2nd international conference, march 26-27 2017. Series: Advances in Intelligent Systems Research. 2017, vol. 132. [Accesat 11.08.2019]. Disponibil: https://www.atlantispress.com/proceedings/msam-17

6. PARKER, Geoffrey, VAN ALSTYNE, Marshall. Two Sided Networks: A Theory of Information Product Design. In: Management Science. 2005, vol. 51 (10). [Accesat 11.08.2019]. Disponibil: https://pubsonline.informs.org/doi/abs/10.1287/mnsc.1050.0400

7. BLIND, Knut. The economics of standards: theory, evidence, policy. Cheltenham-Northampton: Edward Elgar Publishing, 2004. 384 p. ISBN 978-1-84376-793-0.

8. METCALFE, Robert M. It's All In Your Head. 2007, april. [Accesat 11.08.2019]. Disponibil: forbes.com/forbes/2007/0507/052.html

9. MANTA, Otilia. Current Trends of the National Financial Market in the Context of the Global Financial Market. CCFM-INCE, Romanian Academy. 2018, march. [Accesat 11.08.2019]. Disponibil: https://www.researchgate.net/publication/324475305_The_current_trends_of_the_national_fi nancial_market_in_the_context_of_the_global_financial_market

10. ECONOMIDES, Nicholas, KATSAMAKAS, Evangelos. Two-sided competition of proprietary vs. open source technology platforms and the implications for the software industry. In: Management science. 2006, vol. 52 (7). [Accesat 11.08.2019]. Disponibil: http://neconomides.stern.nyu.edu/networks/Economides_Katsamakas_Two-sided.pdf

11. GRANT, Robert M. Contemporary Strategy Analysis. Hoboken: John Wiley\&Sons, 2010. 516 p. ISBN 0-470-74710-2.

12. SUNDARARAJAN, Arun. Local network effects and complex network structure. In: The B.E. Journal of Theoretical Economics. 2008, vol. 7 (1), pp. 1-37. ISSN 1935-1704.

ARTICLE HISTORY

Received 11 September 2019

Accepted 05 December 2019 


\title{
COST-EFFECTIVENESS ANALYSIS FOR HPV MITIGATION STRATEGIES IN THE REPUBLIC OF MOLDOVA BASED ON INFECTIOUS DISEASE MODELLING
}

\author{
Andrzej JARYNOWSKI ${ }^{1}$, PhD Candidate \\ Moldova State University, Chisinau, Republic of Moldova \\ Interdisciplinary Research Institute in Wroclaw, Poland
}

\author{
DOI: https://doi.org/10.36004/nier.es.2019.2-05 \\ JEL Classification: I18, 033, C32, C53, C54, C63 \\ UDC: 614.2: 618.1-006.52-08
}

Human papillomavirus (HPV) is a sexually transmittable virus infection, which is a-necessary risk factor for developing cervical cancer, first killer for working women in Moldova. Since 2018 Moldova has modified the screening program and the vaccination program (mainly funded externally). To assess the performance of the mitigation policy we propose the cost-effectiveness analysis according to 2 already implemented strategies. (1) Vaccination of a single age-cohort, although vaccinating a single cohort may not have a substantial effect in other countries with distinct socio-economic situation. (2) Transition to more technologically advance screening ecosystem (changing from Romanowski to Pap smear), which might not necessary be cost-efficient in low resource settings (if GDP per capita doesn't grow substantially at the same time). (1) We verified that single cohort vaccination is both cost-beneficial (total costs reduction will balance intervention costs around the year 2040) and cost-efficient (with incremental impact in 20 years perspective on the level of 2300 EUR/QALY). Moreover, we found out that single year cohort is more beneficial than 5years cohort vaccination scenarios in our mathematical model. This behaviour could be explained by a transitional situation in Moldova (HPV epidemic is near outbreak threshold), still small changes of model parameters and initial conditions could cause strong effect in the epidemiology. However, a definitive answer cannot be given with the chosen methodology. (2) Transition between Romanowski -> Pap smear cytology in screening benefits unquestionably in epidemiology e.g. due to a higher specificity. However, further maintenance and higher procedure costs could exceed treatment costs, hence intervention costs would gather an unacceptable share of national resources that are limited and that are dedicated to public health.

Keywords: computational social science, epidemiology modelling, cost-effectiveness analysis, HPV and cervical cancer.

Virusul papiloma uman (Human Papilloma Virus sau HPV) este o infecție virală sexual transmisibilă și un factor de risc pentru dezvoltarea cancerului de col uterin - cel mai frecvent tip de boli oncologice la femeile apte de muncă din Republica Moldova. Din 2018, în Republica Moldova a fost modificat programul de screening și programul de vaccinare (finanțat în principal din exterior). Pentru a evalua performanța politicii de atenuare, propunem analiza cost-eficiență în conformitate cu 2 strategii deja implementate. (1) Vaccinarea unei singure cohorte de vârstă, deși vaccinarea unei singure cohorte nu poate avea un efect substanțial în alte țări cu o situație socio-economică distinctă. (2) Trecerea la ecosistemul de screening avansat din punct de vedere tehnologic (schimbarea de la romanowski la frotiul Papanicolau), care ar putea să nu fie necesar din punct de vedere al costurilor în cazul resurselor scăzute (dacă PIB-ul pe cap de locuitor nu va crește substanțial în acel moment). (1) Am verificat faptul că vaccinarea cu o singură cohorta este benefică atât din punctul de vedere al costurilor (reducerea totală a costurilor va echilibra costurile de intervenție în jurul anului 2040), câtși costurile (cu un impact incremental în perspectivă de 20 de ani la nivelul de 2300 EUR / QALY). Mai mult, am aflat că o cohortă unică este mai benefică decât vaccinarea continuă în modelul nostru matematic. Acest comportament poate fi explicat printr-o situație de tranziție în Republica Moldova (epidemia de HPV este aproape de pragul izbucnirii), totuși modificările mici ale parametrilor modelului și condițiile inițiale ar putea avea un efect puternic în epidemiologie. Cu toate acestea, nu se poate da un răspuns definitiv cu metodologia aleasă. (2) Tranziţia între romanowski -> citoplasmă Papanicolau în

1 @ Andrzej JARYNOWSKI, $₫$ ajarynowski@gmail.com 
screening beneficiază, fără îndoială, de epidemiologie, de ex., datorită specificității mai mari. Cu toate acestea, întreținerea ulterioară și costurile de procedură mai mari ar putea depăși costurile de tratament, prin urmare, costurile de intervenție ar aduna cote inacceptabile în întreaga gamă de resurse naționale limitate dedicate sănătății publice.

Cuvinte-cheie: științe sociale, calcul, modelare matematică, analiza cost-eficiență, HPV și cancer de col uterin.

Вирус папилломы человека, или ВПЧ, передаваемый половым путем, является одним из факторов риска для развития рака шейки матки - одного из самых распространенных типов онкологических заболеваний у женщин трудоспособного возраста в Республике Молдова. С 2018 года в Республике Молдова была изменена программа скрининга и программа вакцинации, финансируемые в основном из внешних источников. Для оценки эффективности политики смягчения последствий был предложен анализ экономической эффективности в соответствии с двумя уже реализованными стратегиями. (1) Вакцинация одной возрастной группы, хотя вакцинация одной когорты может не иметь существенного эффекта в других странах с отличающейся социально-экономической ситуацией. (2) Переход к более технологически продвинутой системе скрининга (переход от мазка Романовского к Пап-мазку), который может быть необязательным с точки зрения затрат в условиях ограниченных ресурсов (если ВВП на душу населения не будет одновременно существенно расти). Результаты исследования показали: (1) вакцинация одной когорты выгодна с точки зрения затрат (снижение общих затрат позволит сбалансировать расходы на профилактику примерно к 2040 году) и эффективна с точки зрения затрат (с дополнительным воздействием через 20 лет на уровне 2300 евро / QALY). Более того, мы обнаружили, что в нашей математической модели вакцинация одиночной когорты более полезна, чем непрерывная вакцинация. Такая ситуация может быть объяснена переходной ситуацией в Республике Молдова (эпидемия ВПЧ близка к порогу вспышки), хотя небольшие изменения параметров модели и начальных условий могут оказать сильное влияние в эпидемиологии. Однако использованная методология не позволяет дать однозначный ответ. (2) Переход от мазка Романовского к цитологическому Пап-мазку при скрининге, несомненно, полезен в эпидемиологии, например, из-за более высокой специфичности. Тем не менее, дальнейшее обслуживание и более высокие затраты на процедуры могут превысить затраты на лечение, поэтому затраты на профилактику составили бы недопустимо высокую долю расхода ограниченных национальных ресурсах, предназначенных для общественного здравоохранения.

Ключевые слова: вычислительные социальные науки, Эпидемиологические моделирование, анализ экономической эффективности, ВПЧ и рак шейки матки.

INTRODUCTION. The Republic of Moldova has recently started a battle with health problems as sexually transmittable diseases and cancers, but due to financial crisis, lack of program coordination, partly because of a lack of experience, has still a high morbidity and mortality. From ECDC (European Centre for Disease Prevention and Control) reports [1, 2012] Moldova is a European country with almost highest cervical cancer risks and classified by WHO (Wold Health Organization) in the field of sexually transmitted diseases at the level of countries of the third world [2, 2012]. Additionally, we observed political transformations and beginning of social norm changes in Moldova [3, MOCANU, V., DUMBRAVENAU, A., 2013] as increase of sexuality patterns in number of sexual partners (second demographic transition or post-modernist revolution). We would like to model multi-faceted transmission of diseases [4, ARBYN, M. et al., 2009] in the context of determining the best epidemiological control according to budget possibilities. The optimal preventive guidelines are known: cervical screening practice, teenagers' vaccination and sexual education. In developed countries mitigation strategies are so successful to think even about disease's eradication soon [5, BRISSON, M. et al., 2016]. However, costeffectiveness of the described intervention in resource limited setup is still unknown with high uncertainty in HPV vaccination, screening, and cancer treatment costs. The purpose of this research is to prepare the costeffectiveness analysis of new screening and vaccination guidelines already implemented in Moldova. 
This paper describes epidemiological and financing trends on HPV and cervical cancer in Moldova according to a new program launched in 2018. Around 800k EUR in 2017-2018 was spent on capacity building in new screening technology in cytology and another 600k EUR was spent on vaccination in 2018/2019. We want decision makers to be informed about proposition of changes to be made in the allocation of the health resources required to implement an optimal (cost/effective) prevention program. Thus we examine: (1) a single year cohort vaccination scenario to test its conditional cost-effectiveness (possible sensitivity to sexual partner acquisition rates and country economic growth) as well as; (2) cytology change from Romanowski to Pap (Papanicolau) smears, would not necessary be cost-efficient in low resource settings.

Epidemiology and fact sheets

Human papillomavirus, or HPV, is a sexually transmittable virus infection, which is not only the main, but also a necessary risk factor for developing cervical cancer $[6,2012]$. The time between getting infected by HPV and developing a cancer can be twenty years or more, therefore a dynamic model of human behaviour would be very useful, so that simulations can be made and different scenarios compared. We observe both behavioural change (sexual partner number increases) and demographical change (population ageing) [7, LUPUSOR, A. et al., 2017]. Among the oncogenic HPVs, the most severe one is type 16, present in about half of all cervical cancer cases. We model one HPV strain (16) and imitate multi-strains environment. Recent studies have shown that the main safety precaution with respect to cervical cancer is going to be a combination of vaccination and screening - since only types of specific vaccines (as for type 16 and 18 in our study) are available and there are as many as 15 oncogenic high risk HPVs not covered by vaccine used in Moldova.

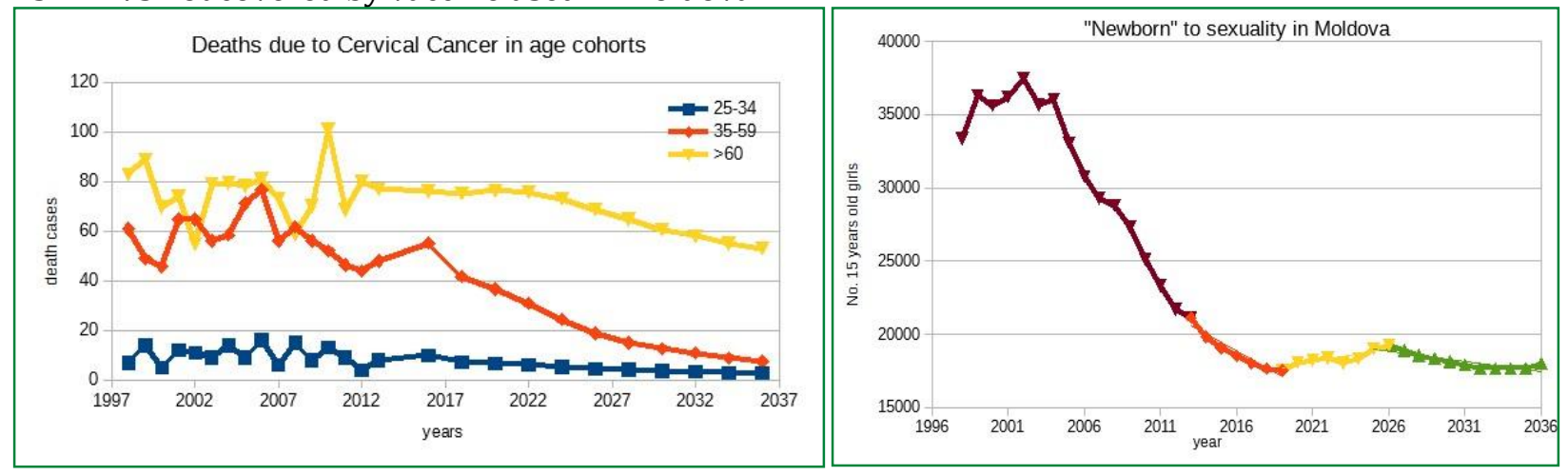

Figure 1. Selected demographical historical data till 2016 and projection (averaged) till 2036. Cervical cancer death cases in age cohorts \{left\}. Number of 15 years old girls entering sexual maturity age \{right\}

Source: Author's calculations based on the Institute of Oncology and Statistics Moldova data.

The Republic of Moldova is one of Europe's poorest nations (whenever we use statistics of Moldova, we mean the Dniester right bank only). Total yearly expenditure on health amounts is limited to just 150 EUR [Fig. 2] per capita (in comparison, the Australian intervention in HPV costs are 8 times higher than the Moldovan one and at the same time consume 5 times less available resources) and reliable data on cervical cancer is missing. Some official statements are untrustable due to a well-known corruption mechanism of reporting "virtual" patients [8, JARYNOWSKI, A., 2015]. The economic situation over the past 2 decades has not allowed for the health systems development [9, SKARPHEDINSDOTTIR, M. et al., 2014]. Till now some statistics differ significantly dependently of data source. Moreover, public health system in Moldova had no capacity to couple with official screening program till 2017 (women $>20 \mathrm{y}$. 0 . every 2 years), where more than 700k test should be done yearly (in 2014 there were around 200k unique cytologies and many sites were already overloaded). Demographically, Republic of Moldova had (in years 1998-2014) a population of 1.4-1.6 million women ages 15 years and older who are at risk of developing cervical cancer. Sexual active woman cohort (age 15-64) was in range 1.25-1.35 millions [10, 2014]. We observe both behavioural change (sexual partner increase) and demographical change (population ageing, but still very young), which both corresponding to second demographic transition since Soviet 
Union collapse. Last 10 years estimates indicate that every year 400-550 (approx. data) women were diagnosed with cervical cancer and 145-220 (register data) died from the disease [11, 2019]. Estimated societal cost was around 5000 disability-adjusted life years (DALYs) every year (or 3000 QALY qualityadjusted life years) [11, 2019; 12, DAVIES, P. et al., 2017]. Cervical cancer ranks as the 2nd most frequent cancer among women in Republic of Moldova and the 1st most frequent cancer among women between 15 and 44 years of age with the share of $39 \%$ of all kind of working age woman cancer cases [12, DAVIES, P. et al., 2017]. The incidence of cervical cancer, had increased from 2005 to 2009. Data on the HPV burden is not available, but generalizing old studies with data from other southeastern European countries, 15$20 \%$ of women in the general population have HPV and $80-90 \%$ had it in their live [13, ROTTGER, J. et al., 2017]. Prevalence of the most oncogenic HPV-16/18 strains is estimated on 25\%. Spatial consideration should be included, while urban/rural sexual behaviour and access to health services differ significantly.

Moldova introduced HPV vaccines in selected subpopulation in 2016 and full coverage of $10 \mathrm{y}$. 0. girls with support from Gavi in 2018 only [Fig. 4]. First national wide suboptimal screening program was introduced in 2013 and updated in 2016 to optimal age-range in almost similar schema as we proposed a year before [12, DAVIES, P. et al., 2017]. The majority of cervical cytology was processed by Romanowski staining technique - standard for the former Soviet Union [14, DAVIES, P., VALUTA, D., 2014].

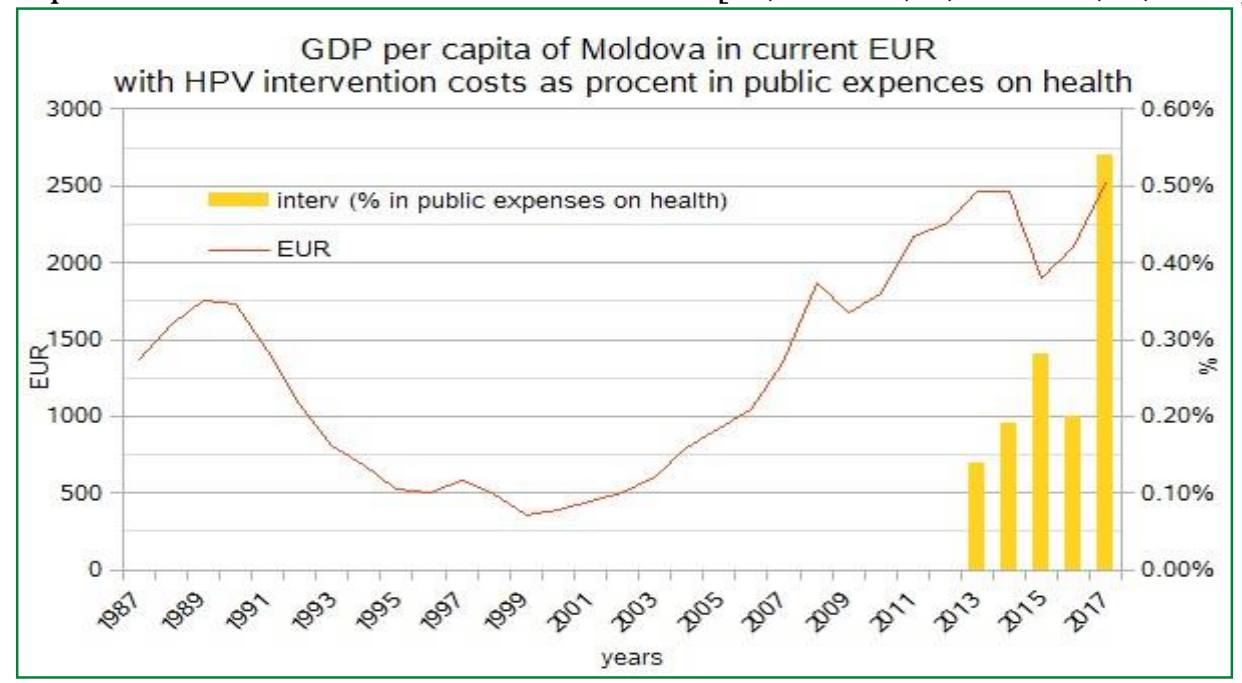

Figure 2. The Moldovan GDP patterns (with unpredictable political and economic situation) \{left $y$ axe $\}$ and HPV intervention costs - the third health expenditure - as \% in total health expenses \{right $y$ axe\}

Source: Author's visualization based on the Statistics Moldova data.

\section{COST-EFFECTIVENESS ANALYSIS}

Let consider more precise monetary and populational effects of intervention used in health economy [15, JARYNOVSKI, A., 2015; 16, 2016]. To do so, we introduce quality-adjusted life-year (QALY) - a measure of disease burden, including both the quality and the quantity of life lived. The QALY is based on the number of years of life and adjusted to health state (where 1 is a perfect health and 0 is death) that would be saved by the intervention. QALY indicates in the best way the benefits of intervention, because it is sensitive to current patient age (literally to current life expectancy). The intervention is highly costeffective if its incremental cost per QALY yearly [17, DAMM et al., 2017] is below GDP per capita of given country ( $\sim 2.5 \mathrm{k}$ EUR for Moldova) or it could be considered as cost-effective if its below $3^{*} \mathrm{GDP}(\sim 7.5 \mathrm{k}$ EUR for Moldova) [18, PHELPS, C., 2016]. In previous papers we showed, that targeted vaccination is costeffective (the incremental QALY between targeted and no vaccination is less than 4k EUR per QALY in 40 years perspective, however practical implementation could be very difficult), while screening the too old and too young woman is not cost-effective (the incremental cost per QALY between national and our scenario was 20k EUR per QALY in 20 years perspective) respectively to Moldova GDP [19, 2014]. It is important to mention, that cervical cancer incidence probably will be decreasing any way in Moldova even with no new additional interventions [20, JARYNOWSKI, A., CERNOV, L., 2018]. Moreover, the 
Moldovan cervical cancer perspective [Fig. 1, 7] looks much better than in other Eastern and Central European countries [21, DOSEKAN, 0., 2010], probably due to recent transition of screening guidelines from opportunistic to organized at the beginning of the XXI-st century [22, DAVIES, P. et al., 2016], and because of a relatively young society with increasing knowledge of STI (sexual transmittable infections).

RESEARCH QUESTIONS. Moldova has modified since 2016 the screening program [14, DAVIES, P., VALUTA, D., 2014] almost the same as we recommended [15, JARYNOVSKI, A., 2015] with small difference in maximum age of screening with 61 instead of 65 which could be an artefact of our age-cohorting schema. Other analytical research approach as PRIME [23, JIT, M. et al., 2014] and OPTIMA [24, GOROSHKO, A. et al., 2015] have provided sufficient cost - effectiveness analysis of standard procedures as screening and vaccination, however their universal tools (both of them were built to be used in many counties) do not fit Moldovan specificity in many details. Big intervention in the period of 2017-2020 with the main objective as reorganization of screening and new vaccination was externally funded in amount of 1.2M EUR [25, 2017]. The Ministry of Health declared the will to continue the vaccination program already for years 2019-2025 [26, 2017], but we are not sure about the real financing of this project (money in amount of 400k EUR are secured for 2019 only [25, 2017]). There is also a strong disbelieve in the Moldovan society about vaccinations safety issues $[27,2019]$ with a strong anti-vaccination political fuel $[28,2018]$. There is still an open question about the cost effectiveness of point (single cohort) vaccinations, because vaccinating single cohort could have no satisfactory effects for the whole population [29, QIAO, M. et al., 2013]. The real scenarios assuming vaccinating 10 y. o. girls in 2018 was not implemented by us, because the first effects would be visible too late for simulation time span. We verify instead a single year vaccination of $14 \mathrm{y}$. o. girls in 2018, so we can keep projection of costs, demographics and epidemiology for the next 20 years only. Quadrivalent vaccine (targeting HPV oncogenic strains 16, 18 , and also non-oncogenic stains 9 and 11 which cause genital warts) is used in 2018, so we introduced additionally to previous studies, effects on genital warts (cost of curing and QALY losses). Increase in cytology cost was also updated due to the change from Romanowski to Pap smear. Vaccination in a single action of a single cohort has not yet been considered from health economic perspective for Moldova. The Moldova case cost-effectiveness analysis is also important to be disseminated worldwide [30, EKWUNIFE, O.I. et al., 2017], due to similar externally founded projects in other Low and Middle Income countries (e.g. GAVI- the Vaccine Alliance).

Research question 1: Testing possible impact of the new 'single' 2018 year project funded mostly by external sources - vaccines for cohort of girls born in $2007 \sim 600 \mathrm{k}$ EUR (400k EUR is a financial cost for program continuation in 2019 with GAVI substitution):

- Estimating incremental costs of adding HPV vaccine in single 2018 to the existing immunization program (reasonable assumption that Moldova will not continue full coverage vaccinating because of lack of resources);

- comparing scenarios of "single year vaccination" in full coverage in 2018 against vaccination of the same amount of girls in the same age but in a 5 year time span (20\% of each cohort each year).

Research question 2: Testing the best budget possibilities according to national screening guidelines since 2018 (Romanowski ->Pap cytology change [31, REBAR, A. et al., 1982]) with capacity building [32, REGAN, D., DONOVAN, B., 2016] cost of 800k EUR (also funded mostly by external sources):

1. Comparing scenarios of various procedure costs per unit (pessimistic - with Romanian price in long term, moderate with Russian price $[33,2019]$ in long term, and optimistic - no significant change).

\section{MODEL AND METHODOLOGY AND ADJUSTING REALISTIC SCENARIOS}

According to provided information, a model for Moldova was proposed. It is a set of deterministic differential equations (implemented in Vensim). Stochasticity [34, GEFFEN, N., SCHOLZ, S., 2017] was introduced in sexual partner matching schema. The model has aggregated the most important path of infection (heterosexual contacts only), cancer development and prevention scenarios (more than 100 equations and 200 parameters). Demographical dataset from comes from "Population and demographic processes" Statistical databank of National Bureau of Statistics [10, 2014; 35, 2017]. HPV dynamics (transmission dynamics via sexual contacts) associated also with the occurrence of cervical cancer (cancer development) was inspired by Polish model implementation [36, JARYNOWSKI, A., 
SERAFIMOVIC, A., 2014]. Mathematical formulation of HPV related issues have been already carefully analysed, because its epidemiology has been widely described and modelled in recent years [32, REGAN, D., DONOVAN, B., 2016; 37, CANFEL, K. et al., 2019]. We have prepared the costbenefit and costeffectiveness analysis for various vaccination strategies, various screening programs with control over other preventive programs (using condoms/sexual education) for Moldova, based on its own demography (sex/age structure with aging and birth/death processes) $[35,2017]$ and sexual behaviour of heterosexual part of population only [38, RAHMAN, Q., 2003]. Population is divided in subcategories (both man and woman) which are aging, transmitting infection and developing cancer, where newborn to sexuality means reaching 15 y. o. [Fig. 3].

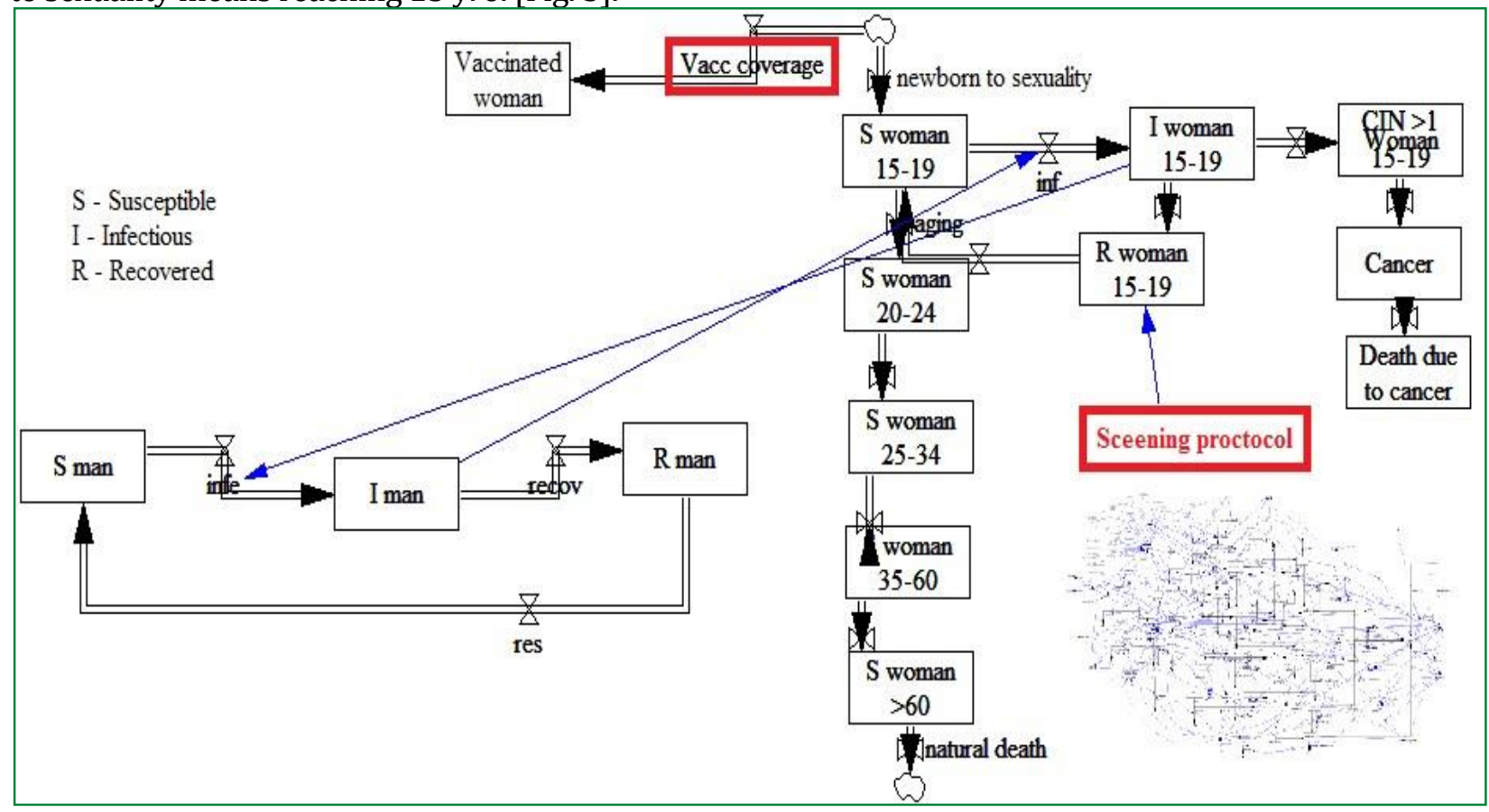

Figure 3. Simplified model methodology with main tunable variables screening protocol and vaccination strategies). Full model in left bottom corner -visualization of this very complicated model in Vensim (Exportable version can be obtained from Github: https://github.com/ajarynowski/HPV_Moldova - free Vensim reader is available from www.vensim.com)

Source: Author's own model available on Github.

We used data since 1998 (2002) till 2014 (2017) to adjust model parameters and we project till our result around 2035 (2038). We use mathematical [39, GRABOWSKI, A., ROSINSKA, M., 2012] and sociological concepts [21, DOSEKAN, 0., 2010] within complex system methodology. Mathematical modelling of infectious diseases transmitted by sexual contacts (as HPV) is increasingly being used to determine the impact of possible interventions (there are dozens of such studies in literature [36, JARYNOWSKI, A., SERAFIMOVIC, A., 2014; 40, ELBASHA, E.H. et al., 2007; 41, RYDING, J., 2008]. We have used probability of infection per a new partner as a main transmission driver. The shape of sexual partner distribution [42, LILJEROS, F. et al., 2000] was followed from Finish study [43, BARNABAS, P. et al., 2006] and adjusted by scaling to obtain mean partners number in Moldova. The most unknown demographical parameter is the increase in partner numbers [44, 2018]. That increase of partner' acquisition was introduced as a modifiable variable and tested for few scenarios $[44,2018]$. In our model woman are stratified in 5 years cohorts (stocks) starting form $15 \mathrm{y}$. o. Effective screening intervals (average interval between smears) were previously implemented as a variable (more important from cost/effectiveness analysis) describing healthcare system capacity [20, JARYNOWSKI, A., CERNOV, L., 2018]. Change of screening procedures from opportunistic to regular is also represented in effective screening frequencies [14, DAVIES, P., VALUTA, D., 2014] and costs [fig. 4]. Condom use was also tunable variable, while sexual education significantly increased in recent few years [45, 2016; 46, JARYNOWSKI, A., 2015]. Standard 
model is better described in extended version of previous report [46, JARYNOWSKI, A., 2015], and new functionalities are mentioned directly in this paper. The model and its parametrization in Vensim environment is publicly available: http://github.com/ajarynowski/HPV_Moldova.

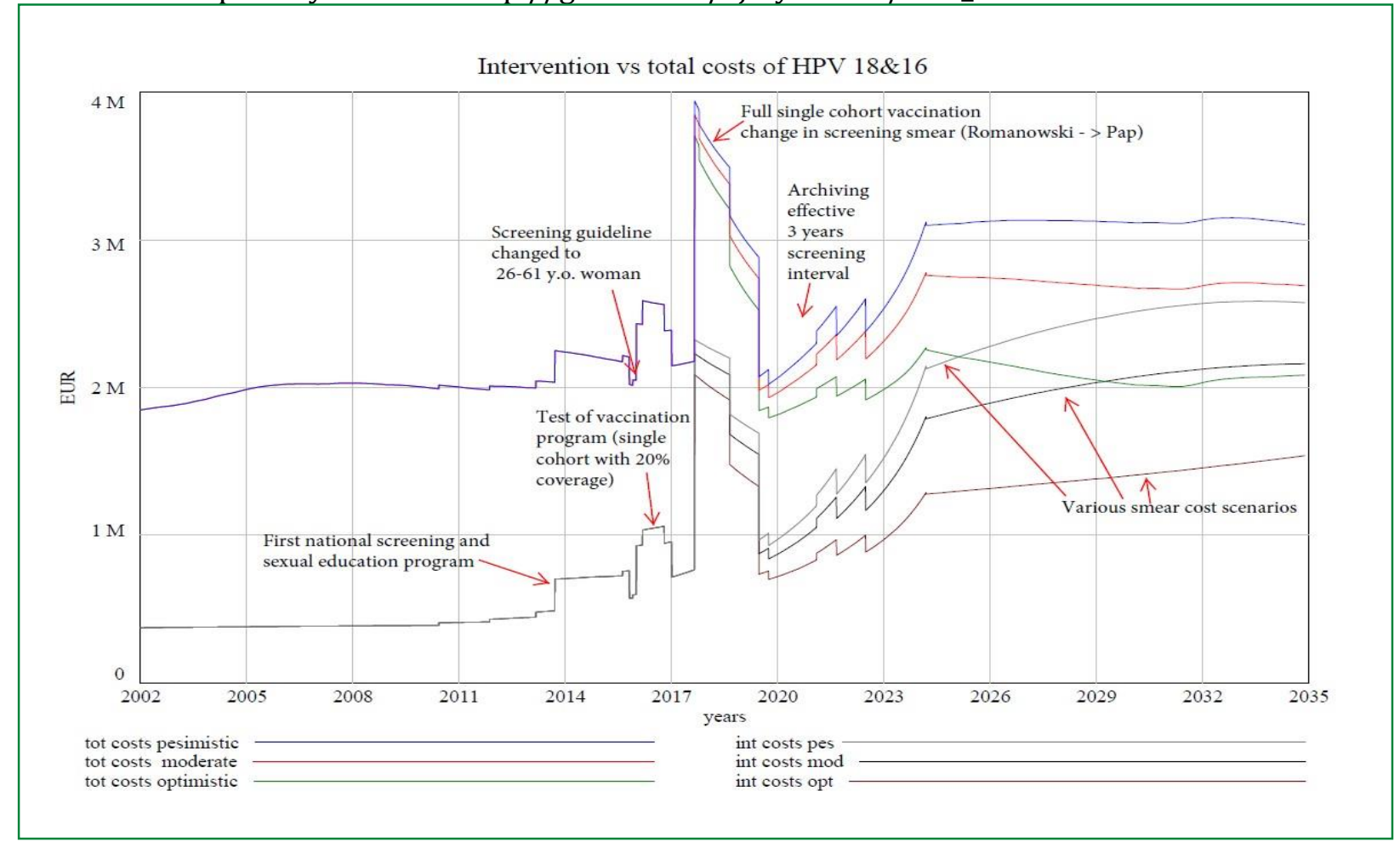

Figure 4. Simplified Moldovan history of pathogenic HPV strains costs. Intervention (int) costs (sexual education, vaccination, screening) and Total (tot) costs (intervention costs with mainly cervical cancer treatment as well as other treatment costs of pre-cancer Source: Authors own projections. abnormalities, anus cancer, genital warts)

In our calculations we provide economic costs (total expenses), which differ from financial costs (Moldova Government expenses), because of the importance of foreign aids. Intervention costs (sexual education, vaccination, screening) till 2017 counts as $1 / 4$ of treatment costs. In big investments in Moldovan Cervical Cancer Program in years 2017-2020 intervention costs (funded by GAVI, World Bank, United Nations Population Fund - UNFPA, Swiss Contribution - SDC, European Union - UE, etc.) exceeds treatment costs.

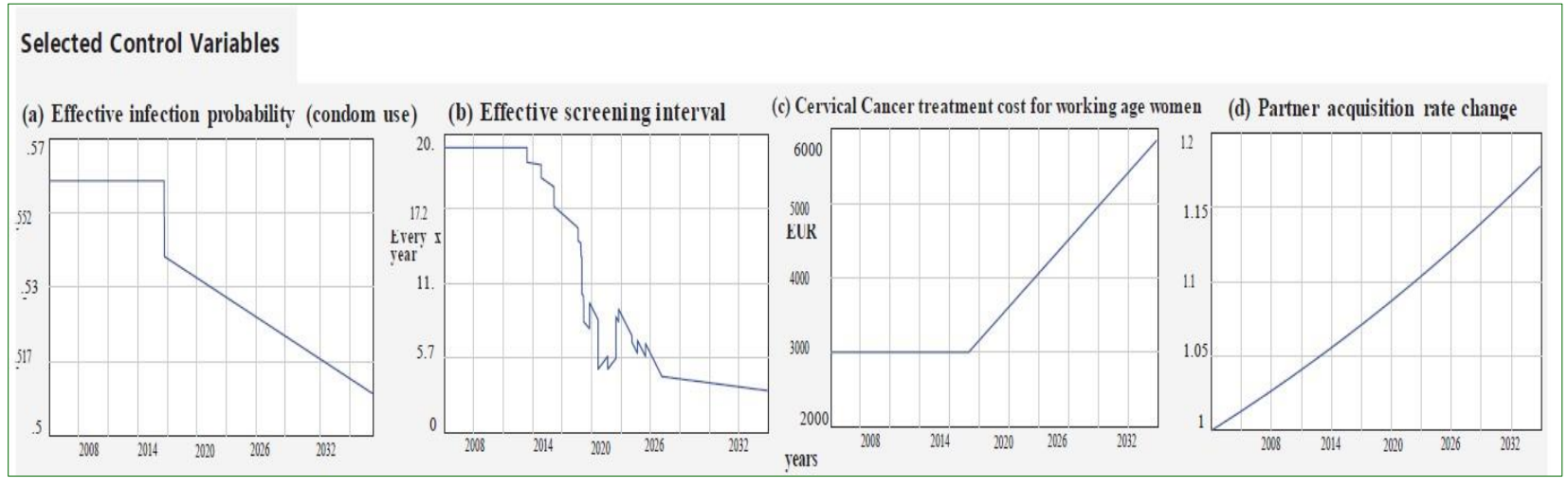

Figure 5. Selected control variables in model projection ((a) effective infection probability - condom use, (b) effective screening interval in years, (c) cancer treatment cost in EUR,

(d) sexual partner change rate as multiplicator)

Source: Author's own assumptions. 


\section{RESULTS - RESEARCH QUESTION 1) ROMANOWSKI->PAP SMEARS}

There is only a little difference in epidemiology between Romanowski and Pap smear in specificity [Tab. 1]. Lower specificity of Romanowski can be corrected by repeated Pap test (mainly with borderline results) [47, DAVIS, P. et al. 2016].

However, there is a substantial difference in cost procedure and Pap smear could be $30 \%$ to $90 \%$ more expensive for a single procedure [Fig. 6], but the same time number of procedures would decreased by around $10 \%$, because there is no need for repetition any more.

\section{Characteristics of smears. False Positive rate change-> test repetition} (up to $10 \%$ due to unclear result)

\begin{tabular}{|l|c|c|c|}
\hline Cytology & $\begin{array}{c}\text { Sensitivity for } \\
\text { morphological } \\
\text { abnormalities in HPV } \\
\text { positive stage without mid- } \\
\text { and high-grade dysplasia }\end{array}$ & $\begin{array}{c}\text { Sensitivity for } \\
\text { morphological } \\
\text { abnormalities in pre- } \\
\text { cancer stage with } \\
\text { mid- and high-grade } \\
\text { dysplasia (CIN }>\text { I) }\end{array}$ & $\begin{array}{c}\text { Specificity for } \\
\text { morphological } \\
\text { abnormalities in HPV } \\
\text { positive or pre- cancer } \\
\text { stage }\end{array}$ \\
\hline Pap & $60 \%$ & $90 \%$ & $98 \%$ \\
\hline Romanowski & $60 \%$ & $90 \%$ & $\sim 90 \%$ \\
\hline
\end{tabular}

Source: Author`s own estimates based on [48, 2013].

While the rising trend in innovative medical technologies (as Pap smear in this case), the chances for efficiency gains and costs reductions are usually large. However, new technology-enabled models of healthcare delivery are not always cost-effective. Capacity building (transitional) costs in this case were covered by foreign sponsors, but equipment amortization and staff cost should be sustain by Moldovan themselves. We try to anticipate costs per procedure in next 20 years [Fig. 6]. We choose target level of future price from Romania (as a pessimistic scenario), Russia (moderated scenario) and current price with most likely interest rate (as optimistic scenario). We assume 15 years amortization period for equipment (characteristic convey curve shape) [Fig. 6]. Reader must be aware, that currently PCR test together with liquid base Pap smear is a standard in developed countries, however machine learning development in image processing for low-cost diagnosis [49, GALLAY, C. et al., 2017] could change whole landscape in next years.

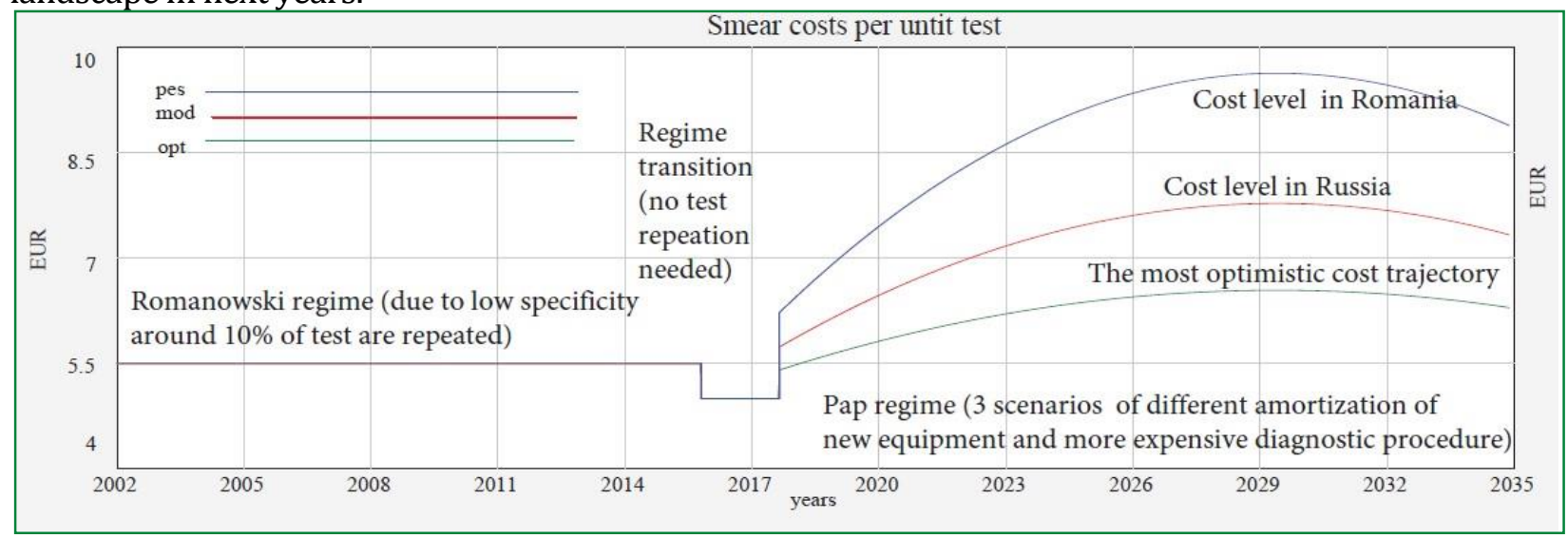

Figure 6. Smear cost per unit for pessimistic (pes), moderate (mode) and optimistic (opt) scenarios. In transitional time window (2017-2018) cost per procedure (operational cost) deceased, because capacity building costs $\sim 800 \mathrm{k}$ EUR (training old and hiring new staff, laboratory equipment etc.) includes partially operational costs

Source: Author's own assumptions.

Let's consider baseline scenario, for which Moldova will stay in Romanowski regime. If we assume that drop-out rate at the level of 20\% in repetition tests, there will be around 12 QALY/yearly loses more that in Pap scenario in 20 years projection. Around 10 cancer cases and 4 deaths could be averted with 
the transition to Pap in 20 years perspective. However, cost comparison is more difficult due to potential instability of Pap procedure price [Fig. 6], so incremental cost-effectiveness vary from 0 in optimistic to 50k incremental EUR/QALY in pessimistic scenario.

Results - Research Question 2) 'Single' cohort vaccination

First of all, we compare the single cohort vaccination against no widespread vaccination at all. Vaccination is both cost-beneficial (total cost reduction balance intervention cost around year 2040) and cost-efficient (with incremental impact in 20 years perspective on the level of 2200 EUR/QALY) [Fig. 7].

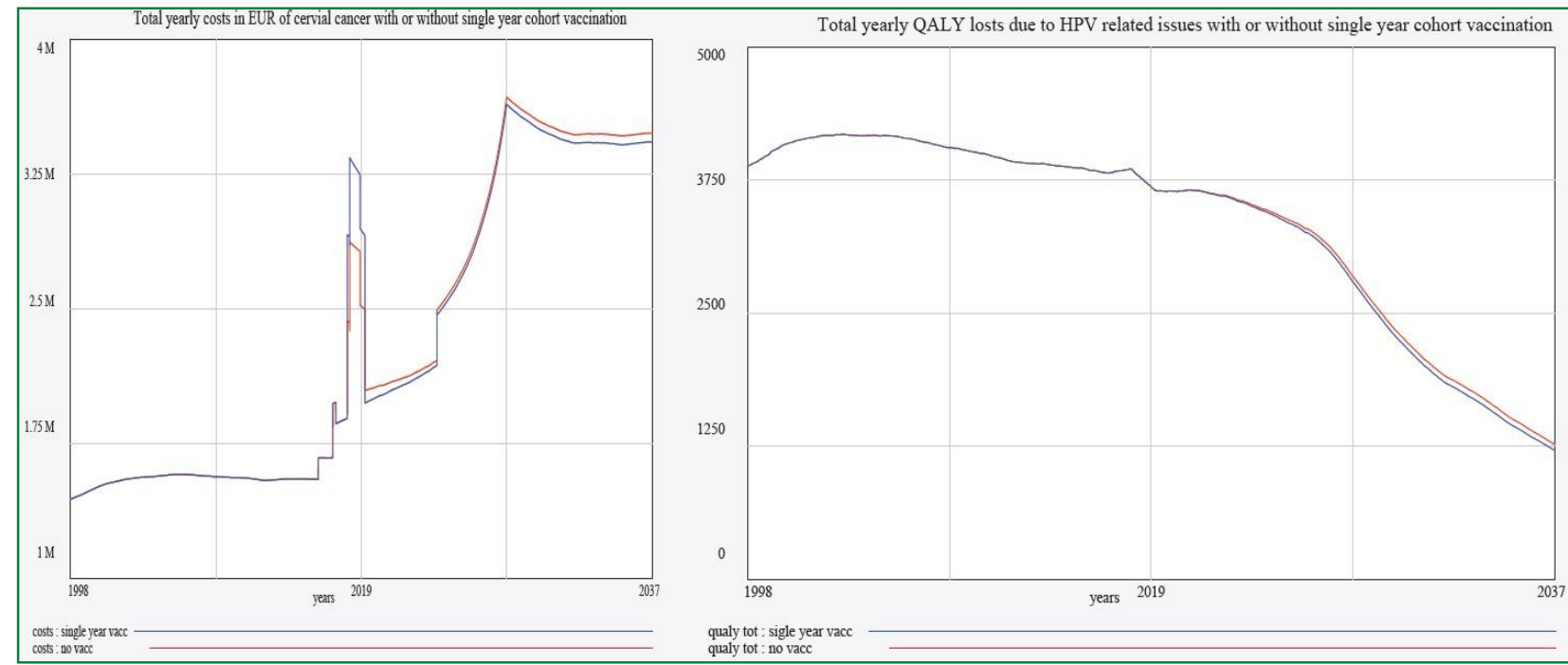

Figure 7. Comparison of total costs of HPV related issued (interventions, genital warts and cancers) \{left\} and QALY losses \{right\} with and without vaccination in 2018

Source: Author's own projections.

Thus we examine such a single year vaccination scenario to show its conditional costeffectiveness in comparison with 5-year cohort vaccination scenario. We assume that 15120 girls has been vaccinated for both single year cohort and 5-year cohort scenarios two years after and before 2018 [Fig. 8].

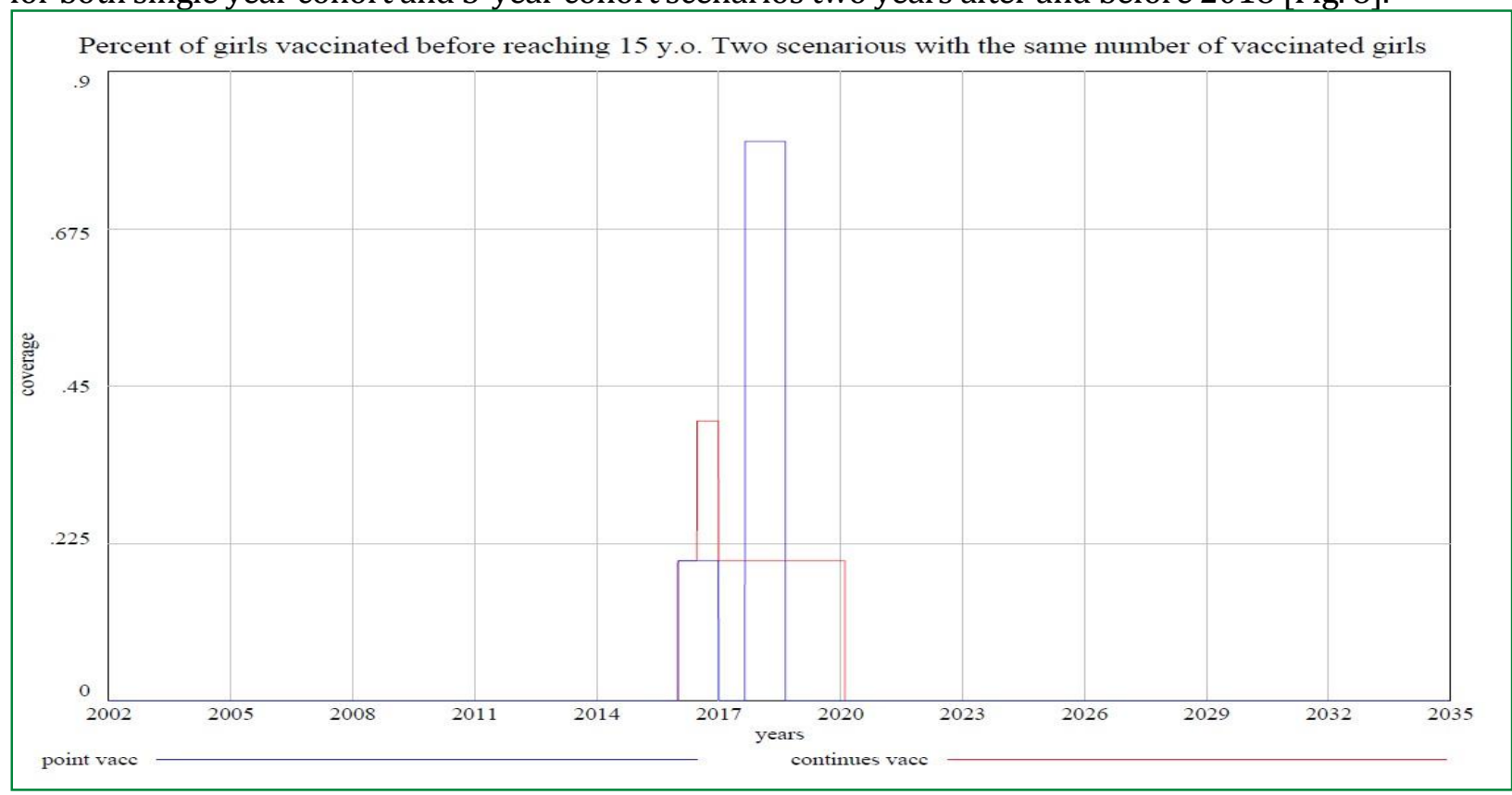

Figure 8. Vaccination coverage of 15120 girls in both scenarios single year/5-years cohort Source: Author`s own assumptions. 
We found out that difference in number of HPV infections is $\sim 610$ and difference in QALY saved is $\sim 80$ in favour of single year against 5 -years cohort vaccination in next 20 years.

Comparing a single year with 5-years cohort in young woman (15-19 y. o.) we observed the increase of infection number between a single year and 5-years cohort scenarios in first 1-2 years (because we started 2 years earlier vaccination in 5-years scenario), then around 2019-2022 there is a significant reduction in infections, and there is no long term difference between scenarios (due to aging moving vaccinated girls to older cohorts). In males, first difference between single year and 5-years cohort scenarios appears in next 5-10 years (when vaccinated women enter their early 20 th years old - the most sexually active period of their life [33, 2019]).

CONCLUSIONS. RECOMMENDATIONS AND LIMITATION

The optimal preventive guidelines for cervical cancer are known [32, REGAN, D., DONOVAN, B., 2016]: cervical screening practice, widespread vaccination and sexual education. However, interventions with the highest impact and lowest price should be prioritized [50, KASPRZYK, R. et al., 2010]. In addition, Moldova - lower middle income country - straggles with challenging demographic processes, like the ageing of the society [51, GAGAUZ, O. et al., 2016; 52, GAGAUZ, O, PAHOMII, I., 2017] and the increase of sexual activity [53, HRUSCIOV, E., 2017] combined with the unstable economic situation [54, PISCHINA, T., 2016]. We suggest (according to our simulation) that the official preventive program for cervical cancer in Moldova is optimal in terms of costs and medical efficiency in vaccination schema and suboptimal in screening protocols (optimal in medical efficiency only). We present a simplified representation of the system with around 200 static parameters and additional 20 time dependent control parameters variables (such as condom use, effective screening interval, partner's acquisition rate, cancer treatment cost [Fig. 5], etc.). We consider different scenarios varying the tunable variables (vaccination coverage type [Fig. 8] and smear cost [Fig. 6]). Exact parametrization of the model used for this paper can be found in repository (github). However, reader must be aware, that presented model and parametrization has been chosen according to a heuristic methodology [55, JARYNOWSKI, A. et al., 2018]. Although we explored other models and parameters configuration, we cannot claim, that our model is the only and the best one for targeting research question 1 (vaccination) and 2 (screening). On the other hand, the main advantage of our model in comparison with well-established modelling tools already applied to Moldova (developed by WHO - PRIME [23, JIT, M. et al., 2014] and sponsored by World Bank OPTIMA []) is its flexibility. In our model, we can test different scenarios (as cohort vaccination, and smear price dynamics), which is not possible or feasible in PRIME and OPTIMA, and our findings should be understood as complementary results only.

The idea of transition from Romanowski to Pap smear cytology (research question 1), is unquestionable (due to higher specificity of the last). However, further maintenance and higher procedure costs [Fig. 6] might exceed treatment costs, implying unacceptable share in whole national limited resources dedicated for public health for intervention costs [Fig. 2, 4]. We found an interesting paradox, that transition to more technologically advanced health system (changing from Romanowski to Pap smears), would not necessary be cost-efficient (incremental cost-effectiveness from 0 to $50 \mathrm{k}$ EUR/QALY) in such low resource settings as in Moldova and unstable GDP growth perspective. Reader must be aware, that we simplified difference between Romanowski and Pap smears in procedure cost (trained staff and lab equipment amortization) and specificity (test repetition in Romanowski method) issue only, even both methods have many variants [57, 2003].

We reopen discussion about vaccination guidelines in low-income countries (as Moldova), where cost of widespread action could be too high for local governments (research question 2). Vaccination could be both cost-beneficial (total costs reduction balance intervention costs before 2037) and costeffective (with incremental impact in 20 years on the level of 2200 EUR/QALY). Moreover, the single cohort (point) vaccination (as it was introduced in Moldova) exceeds the 5 years cohort by approximately 610 less infections and approximately 80 less QALY lost in 20 years' time horizon. The possible explanation of this nonintuitive behaviour might be because HPV in Moldova is rather close to epidemic reproduction threshold rate [55, JARYNOWSKI, A. et al., 2018], still small change of model parameters and initial conditions could cause strong effect in epidemiology. Main effect of intervention is probably via men, which avoid infection (mainly around year 2025 - the peak of sexual activity of vaccinated girls) and will not infect other women. The decrease in infection numbers (and QALY loses in consequence) 
resulting from the 'single' teenage cohort HPV vaccination in 2018 might provide protective effects in heterosexual men through 'local' herd immunity [56, DONOVAN, B. et al., 2011]. This can have an effect probably while changing partners in Moldova is still not as common as in other countries [57, 2003; 58, ROSTAS, I. ș.a., 2014]. However, change in initial conditions and parameter values could diminish positive effect (e.g. higher partner's acquisition rate). Another limitation is System Dynamic approach [55, JARYNOWSKI, A. et al., 2018], so few features as real sexual patterns matching were not implemented. There is no distinguish of rural and urban population or any spatial resolution [59, BELIK, V. et al., 2011] in the model, which have impact both on partner's acquisition and vaccine/screening uptake. Phenomenon of single cohort vaccination cost-effectiveness must be investigated more carefully in different methodology (as ABM Agent Based Modelling [55, JARYNOWSKI, A. et al., 2018]) from presented one (System Dynamics) to understand role of men in immunisation efficacy for example. Moreover, no proper sensitivity analysis could be readily performed using the current methodology (limitation of Vensim software) in presented study, even we have found dependence on changing condition, so only through ABM - obtained results could be generalized. Another limitation is time horizon for 20 years, which is already too far for price/demography/technological assumptions and too short to even test efficiency of vaccination of cohort of $10 \mathrm{y}$. o. girls (so we could test vaccinating $14 \mathrm{y}$. o. instead). We have used aggregated age cohorting [60, ANDERSON, R.M., MAY, R.M., 1992] with 5 years window, which on the one hand side is a popular approach [46, JARYNOWSKI, A., 2015; HORN, J. et al., 2013] - on the second hand it has significant limitations, so year by year analysis could be more proper for single year cohort vaccination schema.

We recommend continuation of vaccination which is both financial (with GAVI substitute) and economic cost-effective according to our model. In terms of screening technology transition: there is no way to go back, however screening costs have to be periodically monitored and national guidelines could be revisited (if necessary) according to economic situation in Republic of Moldova.

\section{Acknowledgment}

AJ would like to thank to Liana Cernov, Florentin Paladi, Ghennadii Gubceac from the Moldova State University, Vitaly Belik from the Free University of Berlin, David Regan, Trevor Dougherty and Richard Gray from the Kirby Institute in Sydney as well as the PANTHER project for partial financial support. Codes are publicly available in a repository: https://github.com/ajarynowski/HPV_Moldova.

\section{REFERENCES}

1. Sexually Transmitted Infections in Europe 1990-2010: surveillance report. European Centre for Disease Prevention and Control. Stockholm, 2012, june. [Accesat 03.05.2019]. Disponibil: https://www.ecdc.europa.eu/sites/portal/files/media/en/publications/Publications/201206Sexu ally-Transmitted-Infections-Europe-2010.pdf

2. WORLD HEALTH ORGANIZATION. Sexual and reproductive health. 2012. [Accesat 11.06.2019].

Disponibil: http://www.euro.who.int/en/health-topics/Life-stages/sexual-and-

reproductivehealth/sexual-and-reproductive-health

3. MOCANU, V., DUMBRAVENAU A. Historical And Socio-Political Aspects Of The Stratification In The Republic Of Moldova'S Society. In: Economie şi Sociologie = Economy and Sociology. 2013, nr. 2, pp. 190-192. ISSN 1857-4130.

4. ARBYN, M. et al. Trends of cervical cancer mortality in the member states of the European Union. In: European journal of cancer. 2009, vol. 45 (15), pp. 2640-2648. ISSN 0959-8049.

5. BRISSON, M. et al. Population-level impact, herd immunity, and elimination after human papillomavirus vaccination: a systematic review and meta-analysis of predictions from transmission-dynamic models. In: The Lancet Public Health. 2016, vol. 1 (1), pp. 8-17. ISSN 24682667.

6. WORLD HEALTH ORGANIZATION. Sexually transmitted infections. 2012. [Accesat 17.08.2019]. Disponibil: http://data.euro.who.int/cisid/?TabID=508968 
7. LUPUȘOR; A. ș.a. Demography matters: How population dynamics impacts the economy of the Republic of Moldova? An analytical report on national Transfer Accounts for the Republic of Moldova. Chisinau, 2017, september 29.54 p.

8. JARYNOWSKI, A. Collapse of cooperation and corruption in a mathematical model within game theory including Moldovan case study (Homo Sociologicus vs Homo Economicus). In: Aspecte ale dezvoltării potențialului economico-managerial în contextul asigurării securității naționale: conferința științifico-internațională, 6-7 iulie 2015. Bălți, 2015, pp. 98-103. ISBN 978-9975-13235-0.

9. SKARPHEDINSDOTTIR, M. et al. Better non-communicable disease outcomes: challenges and opportunities for health systems: Republic of Moldova country assessment. World Health Organization. Health Policy Paper Series. 2014, no. 14. [Accesat 03.05.2019]. Disponibil: http://www.euro.who.int/_data/assets/pdf_file/0008/255464/BetterNCDoutcomesChallenge sOpportunitiesHealthSystemsMoldovaCountryAssessmentEng.pdf?ua=1

10. National Bureau of Statistics of the Republic of Moldova. 2014. [Accesat 23.06.2019]. Disponibil: https://statistica.gov.md/index.php?l=en

11. ICO HPV. Human Papillomavirus and Related Cancers: Republic of Moldova. [Accesat 11.05.2019]. Disponibil: https://hpvcentre.net/statistics/reports/MDA.pdf

12. DAVIES, P. et al. Implementing an organised cervical screening programme in the Republic of Moldova-stakeholder identification and engagement. In: Cancer epidemiology. 2017, vol. 50, pp. 272277. ISSN 1877-7821.

13. ROTTGER, J. et al. Economic evaluation of HPV vaccine introduction in the Republic of Moldova. 2017, march. [Accesat 23.05.2019]. Disponibil: https://www.mig.tu-berlin.de/fileadmin/ a38331600/2017.lectures/Minsk_20170315.wq_Moldova_costeffectiveness.pdf

14. DAVIES, P., VALUTA, D. Capacity Assessment and Recommendations for a National Cervical Cancer Screening Program in the Republic of Moldova. United Nations. Chisinau, 2014, february. [Accesat 14.06.2019]. Disponibil: https://moldova.unfpa.org/sites/default/files/pubpdf/assessmentrecommendations_cervical\%20 cancer\%20screening\%20moldova\%202014_en.pdf

15. JARYNOWSKI, A. Optimal'noe strategii profilaktiki raka šejki matki - model' dlâ Moldovy. V: Naučnyj dialog. 2015, № 1.

16. Republic of Moldova progress report on hiv. United Nations Joint Programme on Hiv/Aids. Chisinau, $2016.33 \mathrm{p}$.

17. DAMM, O., HORN, J. et al. Cost-effectiveness of human papillomavirus vaccination in Germany. In: Cost Effectiveness and Resource Allocation. 2017, vol. 15 (1). ISSN 1478-7547. [Accesat 15.05.2019]. Disponibil: https://resourceallocation.biomedcentral.com/track/pdf/10.1186/s12962-017-0080-9

18. PHELPS, C. Health economics. London: Taylor and Francis, 2016. 551 p. ISBN 9781315510682.

19. WORLD HEALTH ORGANIZATION. Choosing interventions that are cost-effective. Geneva, 2014. [Accesat 03.05.2019]. Disponibil: http://www.who.int/choice/en/ [retrieved 04.10.2019]

20. JARYNOWSKI, A., CERNOV, L. Optimal cervical cancer preventing strategies - model for Moldova. 2018. [Accesat 18.05.2019]. Disponibil:

https://posterng.netkey.at/isid/viewing/index.php?module=viewing_poster\&pi=1415

21. DOSEKAN, O. An overview of the relative risks of different sexual behaviours on HIV transmission. In: Current opinion in HIV and AIDS. 2010, vol. 5 (4), pp. 291-297. ISSN 1746630X.

22. DAVIES, P. et al. Assessment of Cervical Cytology Services in the Republic of Moldova and Recommendations for their Reorganisation to Comply with International Evidence-Based Standards. Chisinau, 2016, december. [Accesat 15.07.2019]. Disponibil:

https://moldova.unfpa.org/sites/default/files/pubpdf/RM\%20Cervical\%20Cytology\%20Assessment\%20\%20Recommendations_eng.pdf

23. JIT, M. et al. Cost-effectiveness of female human papillomavirus vaccination in 179 countries: a PRIME modelling study. In: The Lancet Global health. 2014, vol. 2 (7), pp. 406-414. ISSN 2214109X. 
24. GOROSHKO, A. et al. Optimizing Investments in Moldova's HIV Response. World Bank. Washington DC, 2015. [Accesat 03.05.2019]. Disponibil:

https://openknowledge.worldbank.org/bitstream/handle/10986/25396/109600.pdf?sequenc $\mathrm{e}=5$ \&isAllowed $=\mathrm{y}$

25. SDC. Cervical Cancer Prevention Project in the Republic of Moldova. 2017, november 6. 2 p. [Accesat 03.05.2019]. Disponibil: https://moldova.unfpa.org/en/publications/cervical-cancerpreventionproject-republic-moldova

26. V Moldove 15000 devoček smogut polučit' besplatno vakcinu ot virusa papillomy čeloveka. V:

Moj Mir. 2017, aprel'- iûn'. [Accesat 23.05.2019]. Disponibil: http://positivepeople.md/upload/info/lib/uvt_j05med.pdf

27. Assessment of Knowledge, Attitudes and Practices on Cervical Cancer Prevention in the Republic of Moldova - KAP Survey. 2019, february. [Accesat 11.07.2019]. Disponibil:

https://moldova.unfpa.org/en/publications/assessment-knowledge-attitudes-andpracticescervical-cancer-prevention-republic

28. Efecte adverse ale vaccinului anti-HPV. Ce cred japonezii. 2018, 17 aprilie. [Accesat 03.05.2019]. Disponibil: https://sputnik.md/analytics/20180417/18586258/vaccin-gardasil-cervarixefecteadverse-HPV-informare-ce-cred-japonezii.html

29. QIAO, M. et al. Qualitative analysis of the SICR epidemic model with impulsive vaccinations. In: Mathematical Methods in the Applied Sciences. 2013, vol. 36 (6), pp. 695-706. ISSN 1099-1476.

30. EKWUNIFE, O.I. et al. Challenges in cost-effectiveness analysis modelling of HPV vaccines in lowand middle-income countries: A systematic review and practice recommendations. In: Pharmacoeconomics. 2017, vol. 35 (1), pp. 65-82. ISSN 1170-7690; ISSN 1179-2027.

31. REBAR, A., BOON, G., NICOLA, D. Cytologic Comparison of Romanowsky Stains and Papanicolaou-type Stains II. Cytology of Inflammatory and Neoplastic Lesions. In: Veterinary clinical pathology. 1982, vol. 11 (2), pp. 16-25. ISSN 0275-6382; ISSN 1939-165X.

32. REGAN, D., DONOVAN, B. Balancing the cost-benefit equation for cervical cancer prevention: a moving target. In: The Lancet Public Health. 2016, vol. 1 (2). [Accesat 03.05.2019]. Disponibil: https://www.thelancet.com/action/showPdf?pii=S2468-2667\%2816\%2930024-X

33. European Medical Center. [Accesat 03.05.2019]. Disponibil: https://www.emcmos.ru/clinics/klinika-ginekologii-i-onkoginekologii/ginekologiya

34. GEFFEN, N., SCHOLZ, S. Efficient and Effective Pair-Matching Algorithms for Agent-Based Models. In: Journal of Artificial Societies and Social Simulation. 2017, vol. 20 (4). ISSN 14607425. [Accesat 15.10.2019]. Disponibil: http://jasss.soc.surrey.ac.uk/20/4/8.html

35. National Bureau of Statistics of the Republic of Moldova. 2017. [Accesat 15.10.2019]. Disponibil: https://statistica.gov.md/search.php?go=1\&l=en\&q=2017

36. JARYNOWSKI, A., SERAFIMOVIC, A. Studying Possible Outcomes in a Model of Sexually Transmitted Virus (HPV) Causing Cervical Cancer for Poland. In: Advances in Intelligent Systems and Computing. 2014, pp. 129-141. [Accesat 15.10.2019]. Disponibil:

https://link.springer.com/chapter/10.1007/978-3-642-39829-2_12

37. CANFEL, K. et al. HPV-FRAME: A consensus statement and quality framework for modelled evaluations of HPV-related cancer control. In: Papillomavirus Research. 2019, vol. 8, december.

[Accesat 15.10.2019]. Disponibil: https://www.sciencedirect.com/science/article/pii/S2405852119300230?via\%3Dihub

38. RAHMAN, Q. Born gay? The psychobiology of human sexual orientation. In: Personality and Individual Differences. 2003, vol. 34, pp. 1337-1382. ISSN 0191-8869.

39. GRABOWSKI, A., ROSINSKA, M. The relationship between human behavior and the process of epidemic spreading in a real social network. In: Physics of Condensed Matter. 2012, vol. 85 (7).

[Accesat 15.10.2019]. Disponibil: 
https://www.researchgate.net/publication/257866583_The_relationship_between_human_beh avior_and_the_process_of_epidemic_spreading_in_a_real_social_network

40. ELBASHA, E.H. et al. Model for assessing Human Papillomavirus vaccination strategies. In:

Emerging Infectious Diseases. 2007, vol. 13 (1). [Accesat 15.10.2019]. Disponibil:

https://wwwnc.cdc.gov/eid/article/13/1/06-0438_article

41. RYDING, J. Seroepidemiology as basis for design of Human Papillomavirus vaccination program. In: Vaccine. 2008, vol. 26 (41). [Accesat 15.10.2019]. Disponibil: https://www.sciencedirect.com/science/article/pii/S0264410X08009869

42. LILJEROS, F. et al. The web of human sexual contacts. In: Nature. 2000, vol. 411 (6840), pp. 907908. ISSN 0028-0836; ISSN 1476-4687.

43. BARNABAS, P. et al. Epidemiology of HPV 16 and cervical cancer in Finland and the potential impact of vaccination: Mathematical modelling analyses. In: PLoS Med 3. 2006, vol. 5. [Accesat 15.10.2019]. Disponibil: https://journals.plos.org/plosmedicine/article?id=10.1371/journal.pmed.0030138

44. OECD. Youth Well-being Policy Review of Moldova. 2018. [Accesat 15.10.2019]. Disponibil: https://www.oecd.org/countries/moldova/Youth_Well-being_Policy_Review_Moldova.pdf

45. UNAIDS. Republic of Moldova progress report on HIV/AIDS. Chisinau, 2016. 33 p.

46. JARYNOWSKI, A. HPV and cervical cancer in Moldova, epidemiological model with intervention's cost vs benefit and effectiveness analysis. 2015. [Accesat 11.08.2019]. Disponibil: https://arxiv.org/ftp/arxiv/papers/1504/1504.05383.pdf

47. DAVIES, P. et al. Assessment of Cervical Cytology Services in the Republic of Moldova and Recommendations for their Reorganisation to Comply with International Evidence-Based Standards. Chisinau, 2016, december. [Accesat 11.08.2019]. Disponibil: https://moldova.unfpa.org/sites/default/files/pubpdf/RM\%20Cervical\%20Cytology\%20Assessment\%20\%20Recommendations_eng.pdf

48. Cervical Cancer Screening and Treatment in Low-Resource Settings: Practical Experience From PATH. PATH. 2013. [Accesat 23.08.2019]. Disponibil: https://path.azureedge.net/media/documents/RH_ccp_screening_treatment.pdf

49. GALLAY, C. et al. Cervical cancer screening in low-resource settings: a smartphone image application as an alternative to colposcopy. In: International journal of women's health. 2017, vol. 9, pp. 455-461. ISSN 1179-1411.

50. KASPRZYK, R. et al. Creative Application to Remedy Epidemics. 2010. [Accesat 11.08.2019]. Disponibil: https://www.researchgate.net/publication/229596230_Creative_Application_to_Remedy_Epid emics

51. GAGAUZ, O. et al. Population Situation Analysis in the Republic of Moldova. CCD. Chişinau, 2016. [Accesat 11.08.2019]. Disponibil: https://moldova.unfpa.org/sites/default/files/pubpdf/PSA_engleza.pdf

52. GAGAUZ, O, PAHOMII, I. Youth health and health-risk behavior. In: Economie şi Sociologie = Economy and Sociology. 2017, nr. 4, pp. 94-105. ISSN 1857-4130.

53. HRUSCIOV, E. Population ageing determinants in the Republic of Moldova and selected European Countries. In: Economie şi Sociologie = Economy and Sociology. 2017, nr. 1-2, pp. 148-158. ISSN 1857-4130.

54. PISCHINA, T. Economic growth in the Republic of Moldova - today's challenges and opportunites. In: Economie şi Sociologie = Economy and Sociology. 2016, nr. 3, pp. 54-62. ISSN 1857-4130.

55. JARYNOWSKI, A., BUDA, A., PARADOWSKI, M.B. Modelling communities and populations: an introduction to computational social science. 2018. [Accesat 11.08.2019]. Disponibil: https://www.academia.edu/37401978/Modelling_communities_and_populations_An_introduct ion_to_computational_social_science 
56. DONOVAN, B. et al. Quadrivalent human papillomavirus vaccination and trends in genital warts in Australia: analysis of national sentinel surveillance data. In: The Lancet infectious diseases.

2011, vol. 11 (1), pp. 39-44. [Accesat 11.08.2019]. Disponibil:

https://www.ncbi.nlm.nih.gov/pubmed/21067976

57. Reproductive, Maternal and Child Health in Eastern Europe and Eurasia: A Comparative Report.

Center for Disease Control and Prevention. 2003, april. [Accesat 21.08.2019]. Disponibil: https://dhsprogram.com/pubs/pdf/OD28/00FrontMatter.pdf

58. ROSTAȘ, I. ș.a. Incluziune și excluziune socială: drepturile persoanelor care trăiesc HIV/SIDA în Republica Moldova. Institutul pentru Drepturile Omului. 2014. [Accesat 11.08.2019]. Disponibil:

http://www.crjm.org/wp-content/uploads/2014/04/IDOM.raport.incluziune.2011.rom_pdf

59. BELIK, V. et al. Natural human mobility patterns and spatial spread of infectious diseases. In: Physical Review. 2011. [Accesat 11.10.2019]. Disponibil: http://rocs.huberlin.de/papers/belik_2011a.pdf

60. ANDERSON, R.M., MAY, R.M. Infectious Diseases of Humans: Dynamics and Control. Oxford: Oxford University Press, 1992. ISBN 978-0198540403.

61. HORN, J., DAMM, O. et al. Estimating the long-term effects of HPV vaccination in Germany. In: Vaccine. 2013, vol. 31 (19), pp. 2372-2380. ISSN 0264-410X.

\section{ARTICLE HISTORY}

Received 15 October 2019

Accepted 20 November 2019 
SOCIOLOGY 


\title{
THE PSYCHOLOGICAL CONTRACT IN A GLOBALIZED SOCIETY: NEW CONTRACTUAL AND RELATIONAL FORMS
}

\author{
Stefano AMODIO', PhD in Philosophy, Professor of work psychology, \\ Director of Education², Istituto Teseo, Italy
}

\author{
DOI: https://doi.org/10.36004/nier.es.2019.2-06 \\ JEL Classification: M12, M15, M54 \\ UDC: 159.9:331
}

\section{ABSTRACT}

Today, more and more attention is paid to the functioning of organizations, it is placed not only on the work itself, but on the actors and on those subjective dimensions of the worker. In this socialworking context the psychological techniques and processes aimed at employment in the new scenario of the globalized society have not yet been studied in all aspects, although its diffusion and importance for the global economy is evident. Also the psychological contract, widely discussed, is an argument with insufficient gaps in scientific research, in particular as regards empirical analysis and theoretical interpretative models. Economic literature has never paid much attention to psychological aspects; on the other hand, psychosocial literature has often omitted use as a specific research topic, focusing on traditional placement and outplacement processes. Some scholars, especially from the Anglo-American school, have emphasized the need to direct research towards an interpretative analysis of the psychological contract based on empirical data, also considering the results of managerial and organizational literature. This article focuses on the process of acquiring and transmitting interpersonal dynamics that characterize the psychological contract with the consequent phases of insertion into the working world, describing its characteristics and its specific dynamics. It also provides an interpretation of these processes, adopting a theoretical model derived from the social psychology of interpersonal relationships.

In the end, the article provides some tips to manage the processes of the psychological contract with less stress, psychologically speaking and less organizational uncertainties, mainly addressing the new generations. The purpose of this contribution is to analyze from a psycho-social point of view, the evolution of psychological relationships between employers and workers, within the new scenario of the globalized society, opening new perspectives of investigation and study related to the study of human factors and organizational well-being, work-trust relationships and quality of working preformances.

Keywords: labor market analysis, the psychological contract, psychology of work, Organizational Behavior, Organizational Psychology, Human Resources.

Astăzi, o atenție tot mai mare se acordă funcționării organizațiilor, și nu numai lucrului însăși, ci și actorilor, precum și dimensiunilor subiective ale lucrătorului. În acest context social de lucru, tehnicile și procesele psihologice, care vizează ocuparea forței de muncă în noul scenariu al societății globalizate,

\footnotetext{
1 C Stefano AMODIO, presidenza@istitutoteseo.it, direttore@istitutoteseo.it

2 STEFANO AMODIO, President and Director of Teaching of the Teseo Institute, PhD in General Psychology, teaches Occupational Psychology at the University of Cassino and Southern Lazio, shareholder and co-founder of the Armando Curcio Institute in Rome. Trainer in the field of Human Resources and Labor Organization. He deals with professional training, work psychology, motivation, work well-being, communication mediations, creativity and emotions. He is a member of the technical scientific committee of the Storytelling Observatory of the University of Pavia. Curator and author of several volumes including: Homo Laborans. Tools for analysis and promotion of working well-being (Teseo Editore, 2010) and Johann Amos Comenius. Comenian thought and universal education in the analysis of Didactica Magna (Teseo Editore, 2012), Like leaves in the wind. Work flexibility and atypical scenarios (Teseo Editore, 2011), the latter also translated into Romanian by Editura Romania de Maine, a university publisher of the Spiru Haret University in Bucharest.
} 
nu au fost încă studiate în toate aspectele, deși difuzarea și importanța pentru economia globală sunt evidente. De asemenea, contractul psihologic, discutat pe scară largă, este un argument cu lacune insuficiente în cercetarea științifică, în particular, în ceea ce privește analiza empirică și modelele interpretative teoretice. Literatura economică nu a acordat multă atenție aspectelor psihologice; pe de altă parte, literatura psihosocială a omis adesea utilizarea ca subiect de cercetare specific, concentrându-se asupra proceselor tradiționale de plasare și excluziune pe piața muncii. Unii cercetători, în special din școala anglo-americană, au subliniat necesitatea direcționării cercetării către o analiză interpretativă a contractului psihologic bazat pe date empirice, luând în considerare și rezultatele literaturii manageriale și organizaționale. Acest articol se concentrează asupra procesului de dobândire și transmitere a dinamicii interpersonale care caracterizează contractul psihologic cu fazele ulterioare de inserție în lumea muncii, descriind caracteristicile și dinamica sa specifică. De asemenea, oferă o interpretare a acestor procese, adoptând un model teoretic derivat din psihologia socială a relatiilor interpersonale.

În cele din urmă, articolul oferă câteva sfaturi pentru a gestiona procesele contractului psihologic cu mai puțin stres, din punct de vedere psihologic, și cu mai puține incertitudini organizaționale, adresându-se, în principal, noilor generații. Scopul acestei lucrări este de a analiza din punctul de vedere psiho-social, evoluția relațiilor psihologice între angajatori și lucrători, în noul scenariu al societății globalizate, deschizând noi perspective de investigare a factorului uman și bunăstării organizaționale, relațiilor de încredere în muncă și calității performanțelor de lucru.

Cuvinte-cheie: analiza pieței muncii, contract psihologic, psihologia muncii, comportament organizațional, psihologia organizațională, resurse umane.

Сегодня все большее внимание уделяется функционированию организаций, не только самой работе, но и акторам, а также субъективным характеристикам работника. В этом социальном контексте работы психологические методы и процессы, нацеленные на занятость в новом сценарии глобализованного общества, еще не изучены во всех аспектах, хотя их распространение и значение для мировой экономики очевидны. Также широко обсуждается психологический контракт, являющийся аргументом с достаточными пробелами в научных исследованиях, особенно в том, что касается эмпирического анализа и теоретических моделей интерпретации. Экономическая литература никогда не уделяла много внимания психологическим аспектам; с другой стороны, психосоциальная литература часто исключала использование в качестве конкретной темы исследования, уделяя особое внимание традиционным процессам включения и исключения на рынке труда. Некоторые ученые, особенно из англо-американской школы, подчеркивали необходимость направить исследования на интерпретационный анализ психологического контракта на основе эмпирических данных, а также с учетом результатов управленческой и организационной литературы. Эта статья посвящена процессу приобретения и передачи межличностной динамики, которая характеризует психологический контракт с последующими фазами вхождения в рабочий мир, описывая его характеристики и его специфическую динамику. Это также обеспечивает интерпретацию этих процессов, принимая теоретическую модель, основанную на социальной психологии межличностных отношений.

В заключении статьи приводятся некоторые советы по управлению процессами психологического контракта с меньшим стрессом и $c$ меньшей организационной неопределенностью, в основном адресованные новым поколениям. Цель данной работы проанализировать с психосоциальной точки зрения эволюцию психологических отношений между работодателями и работниками в рамках нового сценария глобализованного общества, открывая новые перспективы для исследования человеческого фактора, организационного благополучия, отношений доверия и качества работы.

Ключевые слова: анализ рынка труда, психологический контракт, психология труда, организационное поведение, организационная психология, человеческие ресурсы. 


\section{INTRODUCTION}

\subsection{Forms and contents of the psychological work contract}

According to Anderson, a psychological contract begins when an employee understands that the organization is obliged to reciprocate somehow what it receives from him. People enter an organization with values, needs and believes which they think will be deeply taken into consideration, and that their prosperity will be protected [1, ANDERSSON, L.M., 1996]. The central point of a psychological contract concerns the exchange of promises and duties whose contents are referred to psychological aspects not put to evidence [2, MAKIN, P. et al., 1996]. These perceptions and expectations are part of the employment psychological contract, which coexists together with the contract formally and legally documented. A psychological contract is oriented to future and it is dynamic and continuously revised, as it is based on expectations evolving during the business collaboration that the person begins with the organization [3, MUCHINSKY, P.M., 2003].

Besides, this contract defines what the person expects from the organization in order to obtain and keep his psychological wealth. The worker believes that the organization has the potential to get this wealth. The terms of this 'contribution' are both in the formal employment contract and in the psychological one. If one of the two is broken, the person feels to be subjected to unfair treatment [4, STALKER, K., 2000]. Nowadays there is no agreement about what a psychological contract is concerned, but there is an agreement about some basic relational elements, as the career development, the participation to the organization, the certainty of the work [5, ANDERSON, N., SCHALK, R., 1998].

According to Anderson and Schalk, one of the main functions of the psychological contract is to reduce employee's insecurity [5, ANDERSON, N., SCHALK, R., 1998]. A Rousseau's comparative study where the contents of the psychological contract and the employers' were compared, revealed that while the employees were expecting advancements, workplace safety, development, wages increase, etc., they were on the contrary asked to be loyal, available to make overtime and extra role duties, a minimum commitment to be in the firm, and the availability to accept transfers [6, ROUSSEAU, D.M. 1990]. According to other researchers working about the psychological contracts, today the work safety is no more connected to loyalty. So, high performances do not assure anymore a work safety [7, CSOKA, L.S., 1995]. For the organizations, loyalty and work involvement have a high value: on the contrary, for the workers the priority is the work certainty.

The reciprocity principle constitutes a fundamental factor to understand the work connection by the worker. Of course, the concept of contract recalls the idea that two parts are involved, and that the reciprocity results by the comprehension and the appreciation of its duties. However, as psychological contracts exist only in the minds of people, a doubt starts about how this mutuality can be carried out between the two parts. In a normal legal contract, every part has his own perception about the contract duties, and the sharing of these perceptions gives mutuality to the parts. Before the signature of the contracts, which gives a legal value to them, ambiguities or misunderstandings are clarified and solved by the two parts.

On the contrary, the psychological contracts are different: actually, they are in the mind of the person, and are not formally negotiated. Only the employee gives substance to this mutuality adopting two points of view: $\mathrm{a}$ ) what he is expecting from the organization; $\mathrm{b}$ ) what he believes the organization expects from him [8, TURNLEY, W.H., BOLINO, M.C. et al., 2003]. These two perspectives influence his behavior and, not directly, how the organization works. According to Denise M. Rousseau, the mutuality is not an essential condition to make the psychological contract exist. She suggests that believing in the reciprocity the contract could exist, but not the reciprocity as such [9, ROUSSEAU, D.M., MCLEAN PARKS, J., 1992]. We can discuss if the organization can have an interest in being an active part in this contract or, more simply, if it can anticipate it. In this case, the satisfaction of the employee's expectations can casually occur at the same time with the obligations of a psychological contract.

Anyway all this does not prevent the organization from understanding which the expectations about the duties are, and from taking sides by accepting these duties, in order to keep productive and advantageous relationships with the employees [9, ROUSSEAU, D.M., MCLEAN PARKS, J., 1992]. New work and organizational dynamics have caused a transition from the so called relational contracts to 
the transactional ones [10, CSOKA, L.S., 1995]. The first ones, in which the relationship between employer and employee is primary, are based on a common interest and are connected to the social exchange, implying an exchange of social and emotional resources [11, MILLWARD, L.J., BREWERTON, P.M., 2000]. They look like a sort of a traditional agreement between employer and employees, in which all the parts recognize the interests of the counter-part [12, MILLWARD, L.J., BREWERTON, P.M., 2000]. Or they can be considered as employment relationships which adopt policies of a high involvement, reflecting a reciprocal interest aimed at reaching positive results [13, TSUI, A.S., PEARCE, J.L. et al., 1997]. According to Kissler, the relational contracts presume a reciprocal relationship of dependency between employees and employers and can show a long term involvement [14, KISSLER, G.D., 1994].

On the contrary, the transactional contracts tend to be static, having a fixed content based on a subjective interest; tend to identify clear responsibilities and to consider short period relationships [15, CAVANAUGH, M.A., NOE, R.A., 1999]. They can be compared to employment relationships focused on the work, in which the result of the transaction is more important of the maintenance of the relationship, and are bound to the exchange of economical resources that constitute the primary incentive [16, MILLWARD, L.J., BREWERTON, P.M., 2000]. Young workers are more inclined to accept transactional psychological contracts then the oldest ones, as they accept a greater work insecurity, when being able to control their career [17, HALL, D.T., 1996].

The diffusion of the transactional contracts, above all among young generations, is considered as an orientation towards a proteiform career, in which the employee has a greater control and responsibility of his own destiny [17, HALL, D.T., 1996]. Of course, these aspects have an influence on the content of the psychological contract. A research that studied the passage from relational contracts to transactional contracts through the study of the perceptions of three family generations, showed that over the years, perceptions of trust, help and loyalty have diminished during the last fifty years. This means a wearing away of the relational elements of the psychological contract $[18, \mathrm{DE}$ MEUSE, K.P. et al., 2001]: indeed, each contract has both relational and transactional elements, so that we have a reciprocal influence. For this reason a relational-transactional codification has been proposed, meant as a psychological-based continuum, where the pure forms of each contract are positioned at each extremity [19, ROUSSEAU, D.M. et al., 1992].

Despite the relational-transactional codification is the main one, we may also have other forms of contract. Some researchers have proposed a codification that takes into account the dimensions of degree and balance of the obligations, identifying six types of contract (instrumental, weak, loyal, strong, unbound, connected to an investment), in which each type shows different levels of emotional bond and work possibilities [20, JANSSENS, M., et.al., 2003]. The researchers have then produced a six dimensioned model with these characteristics: not tangible-tangible; near-distant; stable-flexible; short period-long period; fair-unfair; single-collective [21, SELS, L. et al., 2004]. Watson introduced the idea of ideological contract, saying that a personal position, liberal or collective, influences the judgment about the work relationship, and also the kind of a psychological contract [22, WATSON, G.W., 1997]. Other researchers say that the ideological position does not define a particular and separated kind of contract, but only an internal connotation of the contract itself, that is the possible engagement of a person who tries to pursue a principle or a cause of value.

This task appears as the contribution that the organization has in order to pursue a given ideological target [23, THOMPSON, J.A., BUNDERSON, J.S., 2003]. The engagement due to the cause can increase loyalty, satisfaction and participation to the work organization. These factors confirm a relational dimension of the psychological contract. Adopting the perspective of the social exchange, Shore and Barksdale propose a codification based on a reciprocal balancing of the obligations of the employee and of the employer's as a form of a relationship stronger and similar to a positive psychological relational contract [24, SHORE, L.M., BARKSDALE, K., 1998]. Between the two parts, there can be different needs in this exchange. For example, an individual could have an opposition to invest in a high specialized professionalism that, in time, could prevent him to count on an external position, a chance today possible because of the increasing trend of the transnational contracts, which ask the employees to run more risks in their job. In order to get an exchange able to satisfy the two 
parts, also considering the different interests, the contract should also include the possibility to get tasks with more responsibilities and remuneration connected to the progress of their career.

A second problematic point could be the resistance of the firm to invest its technical capital of knowledge in favor of a given worker. Of course, the firm always works hoping to get as soon as possible an important competitive advantage and to have the guarantee to go on keeping the services of the employee, at least until the return of the investment. In that case, the employer expects that the employee remains in the firm the sufficient time for this return, and that leaving the enterprise, he does not give the knowledge of the firm to his rivals.

In turn, the employee will be available to invest loyally in the firm his career, if he receives the promise to be employed as a long-standing and strategic worker. In this case, a possible breach of the contract will be clear only after the two parts have made their investments in the relationship. In different situations, between the two parts could not be so long a time expectations, and both the single workers and the organization can friendly separate. For example, thank to their kind of employment, the managers tend to commit to long term contracts, in which is very important to keep the employment relationship (a non convertible to cash exchange), while fixed terms workers and consultants prefer transnational contracts. Actually, we see that the type of work relationship influences the content of the relational contract [25, MCLEAN PARKS, J., KIDDER, D.L., 1990].

\subsection{The influence of the new types of work on the psychological contract}

A new interest of the researchers about the psychological contract is in great part fed by recent changes in which the job market has been involved during the last ten years, influencing in a steady way the lives of the workers and the organizations'. On the whole, these changes show a marked orientation to a more flexible market, made of permanent employees, contractors and fixed-term workers. The first ones are considered the core and the intellective force of the firm; the second ones as a sort of stable of contractors, and the last ones as just-in-time workers [26, COOPER, C.L., 1999].

The new organization of the market of work implies a greater individual responsibility concerning the self-development, the career management and more autonomy concerning legal protection [27, CAVANAUGH, M.A., NOE, R.A., 1999]. With reference to the change of organization, concerning a repositioning from the production of goods to the production of services, also the corresponding remuneration is now mainly connected to the market value and less to the position or seniority of the worker. From an individual standpoint, all these changes have produced many consequences when compared with the traditional employment. According to Guest, the main consequences are 1) a reduction of the number of individuals employed;2) an increase of the fragmentation and flexibility of the workers in the firms; 3 ) the urgency and pervasiveness of the changes; 4) an increasing interest for a balance between life and work; 5) the decrease of the number of workers who are represented by the institutional systems of negotiation; 6) a decline of the collective orientation in favor of individualistic solutions [28, GUEST, D.E., 2004].

An interesting Bridges' analysis shows the meaning of these changes in a historical perspective where, starting from the XVII century and later with the industrial revolution, the work became a commitment of tasks, transforming itself in the XIX century into a job. In the XX century these jobs became careers, and nowadays another change is occurring, that is there is a comeback to jobs and tasks considered as a commitment of piece works [29, BRIDGES, W., 1994].

This new relationship is backed also by changes concerning the management of the human resources, where, as an indicator of the attachment, the occupational involvement has substituted the organizational one, and the traditional bounds between property and labor force are becoming less definite [30, GUEST, D.E., CONWAY, N., 1999]. The work relationship goes on evolving, and both the employees and the employers are searching for the basis of a new psychological contract that could be included and accepted, and that could add value to both the parts, instead of being imposed only by the organization, so running the risk of a further loss of the personal power by the worker [31, ROUSSEAU, D.M., 1996].

Looking at the future, it is no more possible to think, if not in rare cases, of a permanent contract and of the idea of one only working career as a main model. The companies are today oriented to be reorganized, joined, rationalized, delocalized and renewed thanks to any form of technological modernization, contributing to make the work more and more multifaceted. So, also the psychological 
contract between an employee and an employer is destined to be redefined. Researchers show that these changes are influencing negatively the motivation and the satisfaction of the workers, and produce an increase of the stress due to the continuous menaces to be dismissed. This last aspect has an important influence about how a worker behaves, included his trust in the organization [32, HENDRY, C., JENKINS, R., 1997]. The staff reshaping is considered by the workers a strong violation of the psychological contract [33, MUCHINSKY, P.M., 2003]. These negative situation has discouraging consequences not only on the individuals interested by this phenomenon, but also on the rest of the workers.

What now the enterprises are communicating to the workers is that they will employ people only until when their capacities and talents are necessary and give an added value to the enterprise. The managers have destroyed the previous psychological contract, but they have not specified terms and conditions of the new one. In this way, they have begun a revolution concerning the manifestation of a new work relationship. The traditional relationship, based on a sharing of values, tasks, loyalty, engagement and vision, has now disappeared. The social contract between employee and employer, where the enterprises could ensure an employment and address the careers of loyal troops has gone to an end forever [34, HERRIOT, P., PEMBERTON, C., 1995].

The change of the focus of the psychological contract depends on some measure by the level of the work: it will be less evident for people working with a permanent contract, as the managers, but not for temporary or definite contracts [35, HANDY, C., 1989]. So, three different forms of psychological contracts have been proposed, which show specific differences in the nature of this form of contract: a life-style contract for part-time and interim workers; an autonomy contract for contract workers; a development contract for permanent workers [36, HERRIOT, P., PEMBERTON, C., 1995]. Also voluntary workers show a new dimension of the work relationship and of the equivalent psychological contract. Even if not paid, they also form a psychological contract with their organizations, but their expectations are not so definite as the ones of remunerated workers [37, FARMER, S.M., FEDOR, D.B., 1999].

Guest and Conway say that is possible to specify a change in the 'promises' that the organizations make to their employees. They are referred more to the conscientiousness and the involvement in the work, but less to the stimulating aspects of work and career [38, GUEST, D.E., CONWAY, N., 2001]. James and Scott specify the same: involvement is better than passivity, powering rather than benefits, adaptation to values but not compliance, development of a general competence but not specialization, competence relocation but not precise functions [39, JAFFE, D. T., SCOTT, C.D., 1997]. They also show a passage from the management to the leadership/coaching, stressing the point on the team inter-functional work, which is so preferred to the functional autonomy [39, JAFFE, D. T., SCOTT, C.D., 1997]. The flatting of the organizations also implies a criticism of the institutional career paths, which nowadays are become protean and with no precise bounds [39, JAFFE, D. T., SCOTT, C.D., 1997].

In the present working contest, the psychological contract has two critical functions: 1) it helps the employers to foresee the contributions given by the employees; 2) it helps the employees to understand which rewards or recognitions they can expect as a result of their contributions. Besides, it forms a useful system to describe how a person can interpret the work relationship in a given moment, giving information how that relationship can be managed, above all in this time, when the work relationships more and more indicate the independence of an individual and not his codependence [40, GUEST, D.E., CONWAY, N., 2001].

A critical environmental factor in the negotiation of the new work relationship and the new psychological contract is the trust. Violations of the psychological contract erase this basic element, causing rage and increasing the level of control. In a place where cynicism is prevailing, trust will be totally absent, and even strengthening when there have been many violations of the psychological contract [41, ANDERSSON, L.M., 1996]. Andersson says that cynicism is often common in a job site as the result of changes of the organization as internal rationalizations and reorganizations [41, ANDERSSON, L.M., 1996]. In the organizations where the decisions concerning the employees are taken unilaterally and with no dialogue, the elimination of the cynicism, the restoration of the trust 
and the reactivation of the psychological contracts can be a very difficult target [42, JOHNSON, J.L., O'LEARY-KELLY, A.M., 2003].

When the individuals feel to be not considered value members of the organization, but only means to get the success of the enterprise, discontent and a motivation decrease are possible. Anyway, violations of the psychological contract very often have to do with transactional aspects (formation, benefits, promotions) more than simple relational needs [43, ARNOLD, J., 1996]. Anyway, the perception of an imbalance in the reciprocity of the contributions, constitutes a cause of conflicts for the psychological contract.

\subsection{Violations of the psychological contract}

The break or violation of the psychological contract has consequences both on the single behavior and on the organizational results. The precondition is that satisfying a psychological contract produces personal positive behaviors, linked to as many positive results for the organization too. So, the organization would have a strong interest to give value to the potential content of the psychological contracts of the employees, both to know and manage the expectations typical of these contracts. What an individual considers a break or interruption could be considered by someone else in the same condition as a violation of the contract. The first is less serious, and implies a cognitive evaluation of the event, while the second is more serious, and produces behaviors and emotional answers that go over the mere cognitive evaluation. So, the two individuals will have different behaviors when facing the same event, what underlines the idiosyncratic nature of the psychological contract [44, FREESE, C., SCHALK, R., 1996].

For istance, for an individual a missed promotion in a given time of his life could be considered not actually harmful for the work relationship, because it could be given in a next future, so the individual does not undertake particular actions against that decision. In other cases, another individual, in the same situation, could think to have received a real bad violation of the psychological contract. All this could induce him to revenge himself of the organization and its interests. It is very frequent that facts which are first considered only interruptions of the psychological contract, are hereafter considered, in a different contest, as bad violations. The understanding of the contents of the contract, and its relationship towards other organizational structures, must be considered fundamental to manage any violation [45, ROBINSON, S.L., MORRISON, E.W., 2000].

Guest proposed a categorization of the results of the satisfaction and the missed gratification of the psychological contract, making a difference between aptitudinal consequences (including reliability, work satisfaction, balance life/work, work safety, motivation, stress) and behavior consequences (including an intention to remain or leaving, work performance, behavior of organization citizenship) [46, GUEST, D.E., 2004]. Employer's violations of the psychological contract will cause a strong reduction of the employee's duties which they feel to fulfill [47, ROBINSON, S.L., 1994]. We can here speak of a feeling of resentment, when describing what they feel after having born an injustice following the results of an individual which has not found a coincidence with a proper cognition. The last one is an implicit contract including what a person can expect to receive as a consequence of his behavior of his performance [48, ORGAN, D.W., 1990]. Wearing away or denying an expected benefit to which an individual thinks to have a right, to brings to the perception of a violation or breaking of the psychological contract, mining the individual's wealth feeling. From a behavioral point of view all this will produce different solutions: a break of the relationship or actions which have as their target a compensation of the violation, or the silence, which always means a form of loyalty and the will to continue the relationship, or destructive behaviors [49, ROUSSEAU, D.M., 1995].

The perception of a break or of a violation of the contract, depends on the interpretation of the importance of the event, but it is also influenced by specific differences as affectivity, a sense of equity and conscientiousness [50, TURNLEY, W.H., FELDMAN, D.C., 1999]. At the beginning, the individual will judge the event in order to understand if the organization has refused the obligation or if there is an incongruence in his expectations. The evaluation of the importance of an event can increase his monitoring of the tangible results of the contract. If the importance of the promises not recognized is part of what the individual is ready to accept, he will perceive a break of the contract; but if the break goes on any reasonable negative expectation, it will be prevalent a feeling of violation, and this will 
mean that the individual will behave as follows: He could leave the organization, what he could actually do; he could complain in order to get a public recognition of the violation; he could also decide, considering more details, that the new situation is not a menace for him, remaining loyal and continuing his relationship, but at the same time reducing his involvement. The last probability could be an effort to know the details of the violation, in order to revenge of the organization, and beginning to act in a harmful way [51, MORRISON, E.W., ROBINSON, S.L., 1997]. Despite all studies have analyzed till today cases of not recognition of the psychological contract, some researchers have shown a situation in which the expectations have been gratified in an exceeding way, also showing that in such cases many problems could arise.

Even a hyper-gratification of the psychological contract can be perceived by the individuals as a break or a violation of the contract. For istance, while a given autonomy in the work can be considered one of the expectations of the contract, too much autonomy could be harmful, and the individual, feeling himself abandoned, could have a bad stress able to increase the perception that the contract is being broken [52, TURNLEY, W.H., FELDMAN, D.C., 1999]. Of course, an under gratification must usually be considered worse than a hyper-gratification. A further reaction to the break or violation of the psychological contract is the silence of the employees. Their inactivity and a missed manifestation of reactions must not be considered an implicit agreement of the situation, and in this case the loyalty towards the organization will be spoiled [53, PINDER, C.C., HARLOS, K.P., 2001]. A proactive management of the psychological contract is to be considered important in such a situation. Making mistakes in the management of the violations of the contract, both for its content and the process, can cause many negative consequences for the organization, jeopardizing the fulfillment of the targets caused by a refusal of their engagement and dedication to work, the postponing of the commitments, the slowing of the work, anxiety and discord [54, BROOKS, I., HARFIELD, T., 2000].

\subsection{Results of the dismissal on the psychological contract}

Dismissals and severe reductions of employees in an organization usually are considered causes of many organization problems. One of the results coming out from the studies on this sector, is the reaction of the workers who remain in the organization. This phenomenon, also known as survivor's syndrome, is considered an important factor regarding the failure of the enterprise targets after the downsizing of the employees [55, APPELBAUM, S.H., 1999]. Negative reactions can imply rage, depression, fear, guilt, refusal of risk, distrust, vulnerability, impotence, loss of motivation [56, NIXON, R.D., HITT, M.A. et al., 2004]. Other phenomena can be an opposition to changes, unwillingness to sharing information and team work, besides further emotional reactions that rise the negativity of the employees, influencing negatively the moral sense of the person, in whom takes place the idea that the dismissals are a betrayal [57, STAVROU, E. et al., 2007]. Medical studies show an increasing of endorsed ills and a risk of death for the workers who remain in the firm after a staff reduction [58, VAHTERA, J. et al.,1997].

Anyway, the negative effects are strongly connected to a perception of fracture and violation of the psychological contract towards the workers on the whole. A feeling of distrust against managers and bosses rapidly spreads, as they are considered guilty for having made nothing to 'save' their colleagues. According to some researchers, this should be a defense mechanism, through an external transfer of the responsibility for what has happened, and aimed to face their own guilt feeling as survivors [59, MANSON, B.J., 2000]. So, in order to minimize such phenomena, it is fundamental the accuracy by which the organization reduces the employees, and above all the management of the negotiation of the new psychological contract, and the building of a new work environment, capable to balance the distrust, with initiatives aimed to favor a reciprocal investment, saving the congruence between the targets of the 'survivors' and the ones of the organization. Of course, a dismissing is considered the worst menace when managing the employees. If on one side the survivors feel guilty and 'different' to have been saved, on the other side fear to be the next ones on the black list. Severe interventions with cuts of the personnel, if not progressive in time, will arise the feeling of menace, with managers' reactions aimed to centralize their control and with an important reduction of the involvement in the choices of the enterprise, together with a strong attention on formal procedures and rules [60, BURKE, R. LEITRER, M.P., 2000].

If the reshaping of the employees is perceived as limited and temporary, also the rigidity of the 
reactions will be limited; if the contrary, if the diminishing of the human resources should be greater, the rigidity becomes greater too, as a reaction to an increase of the perception of the insecurity and personal menace. The increase of the stress will produce a greater conflict and irresponsibility and a lesser organizational involvement [61, LEWIN, J.E., 2001]. The feeling to have lost the control of the situation, and the insecurity about one's own work future, will increase the individuals' stress. The increasing of the work (more daily hours of work) and the diminishing of holidays days, can strengthen this reaction, sometimes causing burnout and inefficiency. These reactions are more evident when the dismissing is unexpected and concentrated in short period of time, with little communication by the organization, and without any participation of the workers [62, MONE, M., 1999]. Anyway some studies show the cases of individuals who, after the dismissing, increased their efforts and productivity: but these are to be considered not durable effects but a mere reaction caused by fear [63, ARMSTRONG-STRASSEN, M., 2006]. The hidden costs of the organization to dismiss their employees - when considered a form of strategic rationalization - are often underestimate. In fact, they produce more problems than solutions, and only rarely they get the financial targets that the organization expects, as the consequences on the employees affect the general productivity [64, CARBERY, R., GARAVAN, T.N., 2005]. One of these consequences is the perception of an increase of the work. Readjusting the organization can signify that the employees from now on will perform tasks never performed before, and for which they are not ready, both technically and for the information they do not have.

So, there will be instability in the labor force, above all if a plan capable to drive the employees in the passage to the new structure is missing. New responsibilities concerning tasks carried out by colleagues dismissed, will produce burnout phenomena, frustration, a downfall of the employees' involvement in the organization and of their engagement in favor of the enterprise [64, CARBERY, R., GARAVAN, T.N., 2005]. Also a block of employments or early retirements can induce other workers to leave or change the enterprise, and they will be above all the most ambitious and productive workers. The results will be an escape of the best resources, and rapidly also its 'memory' will be cancelled, and only a group of discontented workers will stay, overcharged by work and with a not proper education for their tasks. Absenteeism and envy for the ones who have succeeded in finding a better employment or a good retirement will increase [65, KINNIE, N. et al., 2000].

A reduction of the employees changes both social relationships and work conditions. The first consequence of the increasing of the internal competition (basically provoked by the fear of uncertainty and by the wish to 'save' oneself), will produce conflicts and resentment among colleagues, caused by presumed racial or geographical preferences [66, KOEBER, C., 2002]. The perception of the justice of the organization depends mostly by the executive modes of the internal downsizing plan of the employees. If they perceive the layoff as unfair and incorrect, they will keep on projecting these judgments on all the contest of the following work, feeding uncertainty and distrust towards the organization.

The judgments of people who were considered important before the layoff, will influence the perceptions of other workers about the justice and the correctness of the organization [67, BROCKNER, J., WIESENFELD, B. et al., 1997]. In general, we can distinguish two types of reaction, according to the mode how the 'victims' have been selected, and later treated by the management: a sympathetic reaction and a non sympathetic reaction [68, THORNHILL, A.S., MARK, N.K., 1998]. The first one expresses an identification with the situation of the colleagues unfairly stricken by the layoff, and causes negative emotions and reactive behaviors against the organization. The force of the reactions is connected to the previous inter-connection with the 'victims', and by the presence of behaviors, values and experiences shared by the workers. Also being already dismissed favors a strong sharing of the situation of the colleagues.

On the contrary, a non sympathetic reaction expresses a psychological estrangement from the situation: what happened was necessary and right; the people involved have been selected in a right mode, and they have deserved in a way or another what happened to them. In order to reduce their guilt towards the colleagues dismissed, some employees increase their productivity and engagement, but it is a short range reaction, a negation behavior or rather a reaction caused by fear and insecurity about their work future. Some studies underline that the reaction of indifference is more frequent in 
the highest levels of the chain of command [69, CAMERON, K.S., 1994].

On the whole, the redrafting of the employees, rather than renew the system, as desired, creates on the contrary a series of negative consequences which end with the dissatisfaction and the inefficiency of the workers, and with low quality services, in turn influencing negatively the judgment of the customers. The perception of a missed acknowledgment of the procedural justice in the enterprise, lows down above all the engagement and enthusiasm of the medium management, who is in charge for executive tasks and for the strategic management of the human resources. The new behavior will cause a reduction of the initiative and the liveliness of the workers, who stick rigidly to a status quo position, losing any productive enthusiasm and any chance of a competitive re-launch in a next future [70, PARKER, S.K. et al., 1997].

\subsection{The management of the new psychological contract}

The organizations cannot offer anymore a work certainty, but at the same time do not want to give off the old loyalty and dedication of their employees, which will be promoted through alternative strategies, above all to motivate their most intelligent employees after the reduction of personnel. This will need a continuous sequence of negotiations of the psychological contract that individuals and organizations stipulate during the time of work [71, HERRIOT, P., 1992]. For many firms, all this needs a change of their management of the organization: from the traditional form of control to the significance and weight given to the participation, to the team work and to the individual involvement.

It is today evident that a well identified role, symmetric communication, decentralization and a direct participation about the decisions develop involvement and engagement of the employees [72, LAWLER, E.E., MOHRMAN, S.A., 1989]. The idea of the employee's total involvement shows that the management should grant to the workers both sharing of the risks and rewards [72, LAWLER, E.E., MOHRMAN, S.A., 1989]. The management should make an effort to define tasks and structures capable to allow the individuals to feel satisfied, and express and use their capacities in order to employ their decision power. Of course, the challenges able to favor a self development are favored by a high involvement and identification with the organization. So, it is very important that the new employees could begin their socialization inside the organization through work tasks able to encourage their development. In order to obtain efficiency and effectiveness, the organization needs to complete but not to impose its values and tasks against the workers', so that they could reasonably to think that if the organization develops, they will have a personal developing too. So, the organizations must develop a new involvement thanks to the creation of values coming from the individuals and from the groups, and that are not impersonally handed down from above [73, ARMSTRONG, M.A., 1991]. Only the recognition of intrinsic motivating factors will permit the employees to be more dynamic, proactive and competitive.

The new psychological contract is based on the hypothesis that the workers will not be automatically faithful to their firm, but, being professionals, they will oriented to a new type of loyalty, focused not on the firm but on their own competences. This means that the individuals will be above all careful to their personal development and to their competences, which make them more mobile from an enterprise to another [74, KANTER, R.M., 1994]. In order to attract and retain the most qualified employees, the enterprises can no more entrust to old or traditional methods. Instead of career paths or the certainty of their work, new types of incentives will be used: from the career, the status and the promotion to the personal reputation, to the team work and to demanding tasks. The enterprises must find the way to make the work involving and stimulating, so that it could become a reason to be loyal to the firm, so becoming a different type of certainty: the employability certainty. It is in fact the promise that the employee's abilities will be promoted, and that it will be easier for him to get different tasks. According to Kanter, above all nowadays, in a time of rapid and continuous changes, this will be the best promise that an employer could make to his staff [74, KANTER, R.M., 1994].

Many studies show that the workers' values and expectations are rapidly changing. They more and more want to be informed about what happens in the organization; they want to understand why the managers have decided in a certain way; they want to contribute with their ideas and take part to the decisional process; they want to be autonomous and have important work experiences; they want to be given value and have a recognition as individuals because of the contribution they give to the success of the organization [75, O'REILLY, B., 1994]. Satisfying these expectations, needs to be really

No. 2 / 2019 
oriented to a team work, to the empowerment and to the decentralization, besides an important engagement for an honest and clear sharing of the information concerning the enterprise.

It can be very difficult to be honest for what concerns the uncertainty of the work, but many organizations have discovered that when they openly share with all the employees their strategic plans, intentions and results, the engagement towards the organization and the working performances increase, even if the news is 'bad'. So the building of a real open culture probably is one of the most important tasks of the leadership of the next future [75, O'REILLY, B., 1994]. One of the most significant matters of the new psychological contract, is how to place the eldest clerks when the enterprises ask continuously their employees to be more flexible to the changes, in a time when certainty of the work and promoting chances are reducing. An obvious solution seems to offer an updating to the ones who will be requested to change their role in the organization, or to offer an outplacement to the dismissing employees or to the ones who decide to leave the organization. Anyway, not all will be updated or employed again.

A main reason of these limits is constituted by the perceptions that the individuals have of themselves. The problem is the capacity to change their mentality: they must not only think of their development or their career, but they should develop a wide range of competences which could give more value to their profession [76, LESTER, T., 1994]. The main target is the increasing of flexibility, the competences and the employability of the workers. In the organization it should be necessary to increase steadily a system able to settle and discuss the workers' expectations about the work they make, starting already from the first working day, and then continuing with recurring evaluations in order to understand the validity of the psychological contract, and renewing it when necessary [77, HILTROP, J.M., 1995]. As the starting phase of the employment is particularly important for building up a future employee's background, it will be absolutely necessary to pay close attention to how the new employees enter the organization.

A greater part of the new employees tends to work with over-dimensioned expectations [78, LOUIS, M.R., 1980]. It should be better to give a realistic preview of their work, in order to show both enticing and not enticing aspects of an organization, rather than to approach by traditional means, that try to underline the positive aspects of the organization and minimize the realistic ones. Beginning a work, disappointed expectations mean a lack of engagement and an increase of the turnover during the first six months. In a situation where everyone is asked to make their duties as better as they can, to be fast and efficient, the satisfaction system should recognize the individual's contribution, rather than his status.

Besides, as the inter-functional projects are usually temporary and less hierarchical, also the system of rewards should more dynamical and flexible, thanks to recognitions and remunerations as bonuses, benefits and so on. These should encourage the employees to better their work and study key expertise through their participation to inter-functional teams. For this reason, the individuals shall be trained by counseling and coaching, in order to better carry out their leadership, facilitating the relationships between different functions and jobs in a working team [79, PFEFFER, J., 1994]. The transition of an organization towards a new psychological contract, implies the necessity to strengthen above all the planning of the human resources, and to renew on the whole the working relationship, paying specific attention both to the redeployment and when the worker will leave the work, in order to better understand and manage the building and mediation dynamics of the expectations and the needs of the workers during the working cycle [80, BURACK, E.H., MATHYS, N.J. 1987].

\section{REFERENCES}

1. ANDERSSON, L.M. Employee cynicism: an examination using a contract violation framework. In: Human Relations. 1996, 49 (11), pp. 1395-1418. ISSN 0018-7267.

2. MAKIN, P., COOPER, C., COX, C. Organizations and the Psychological Contract. Westport, CT: Greenwood, 1996. ISBN 978-0275956851.

3. MUCHINSKY, P.M. Psychology Applied to Work: an introduction to industrial and organizational psichology. Belmont-Wadsworth, 2003. 550 p. ISBN 0534596258.

4. STALKER, K. The individual, the organization, and the psychological contract. In: The British Journal of Administrative Management. 2000, pp. 28-34. ISSN 1353-5188. 
5. ANDERSON, N., SCHALK, R. The psychological contract in retrospect and prospect. In: Journal of Organisational Behavior. 1998, vol. 19, pp. 637-647. ISSN 1099-1379.

6. ROUSSEAU, D.M. New hire perceptions of their own and employer's obligations: a study of psychological contracts. In: Journal of Organizational Behavior. 1990, vol. 11 (5), pp. 389-400. ISSN 1099-1379.

7. CSOKA, L.S. A new employer-employee contract? In: Employment Relations. 1995, vol. 22 (2), pp. 21-31. ISSN 1520-6459.

8. TURNLEY, W.H., BOLINO, M.C. et al. The impact of psychological contract fulfillment on the performance of inrole and organizational citizenship behaviors. In: Journal of Management. 2003, vol. 29 (2), pp. 187206. ISSN 0149-2063.

9. ROUSSEAU, D.M., MCLEAN PARKS, J. The contracts of individuals and organizations. In: L.L. CUMMINGS, B.M. STAW. Research in Organizational Behavior. Greenwich, CT: JAI Press, 1992, vol. 15 (2), pp. 1-43.

10. CSOKA, L.S. A new employer-employee contract? In: Employment Relations. 1995, vol. 22 (2), pp. 2131. ISSN 1520-6459.

11. MILLWARD, L. J., BREWERTON, P.M. Psychological contracts: Employee relations for the twenty-first century? In: C.L. COOPER, I.T. ROBERTSON. International review of Industrial and Organisational Psychology. John Wiley \& Sons, 2000, vol. 15, pp. 1-61.

12. MILLWARD, L.J., BREWERTON, P.M. Psychological contracts: Employee relations for the twenty-first century? In: C.L. COOPER, I.T. ROBERTSON. International Review of Industrial and Organizational Psychology. 2000, vol. 15, pp. 1-61. ISBN 978-0-471-85855-3.

13. TSUI, A.S., PEARCE, J.L. et al. Alternative approaches to the employee-organization relationship: Does investment in employees pay off? In: Academy of Management Journal. 1997, vol. 40 (5), pp. 10891121. ISSN 1948-0989.

14. KISSLER, G.D. The new employment contract. In: Human Resource Management. 1994, vol. 33 (3), pp. 335-352. ISSN 1099-050X.

15. CAVANAUGH, M.A., NOE, R.A. Antecedents and consequences of relational components of the new psychological contract. In: Journal of Organizational Behavior. 1999, vol. 20 (3), pp. 323-340. ISSN 10991379.

16. MILLWARD, L.J., BREWERTON, P.M. Psychological contracts: Employee relations for the twenty-first century? In: International Review of Industrial and Organizational Psychology. 2000, vol. 15, pp. 1-61. ISBN 978-0-471-85855-3.

17. HALL, D.T. Protean careers of the 21st century. In: Academy of Management Executive. 1996, vol. 10 (4), pp. 8-16. ISSN 1079-5545.

18. DE MEUSE, K.P., BERGMAN, T.J., LESTER, S.W. An investigation of the relational component of the psychological contract across time, generation, and employment status. In: Journal of Managerial Issues. 2001, vol. 13 (1), pp. 102-118. ISSN 1045-3695.

19. ROUSSEAU, D.M., MCLEAN PARKS, J. The contracts of individuals and organizations. 1992, pp. 1-43. [Accesat 23.09.2019]. Disponibil:

http://web.mit.edu/curhan/www/docs/Articles/15341_Readings/Justice/TheContractsOflndividuals AndOrganizations_RosseauParks.pdf

20. JANSSENS, M., SELS, L., VAN DEN BRANDE, I. Multiple types of psychological contracts: A six-cluster solution. In: Human Relations. 2003, vol. 56 (11), pp. 1349-1378. ISSN 0018-7267.

21. SELS, L., JANSSENS, M., VAN DEN BRANDE, I. Assessing the nature of psychological contracts: a validation of six dimensions. In: Journal of Organizational Behavior. 2004, vol. 25 (4), pp. 461-488. ISSN 1099-1379.

22. WATSON, G.W. Beyond the Psychological Contract: Ideology and the Economic Social Contract in a Restructuring Environment. 1997. [Accesat 23.09.2019]. Disponibil: http://scholar.lib.vt.edu/theses/available/etd-3213172239721111/unrestricted/Dissert\&.pdf

23. THOMPSON, J.A., BUNDERSON, J.S. Violations of principle: Ideological currency in the psychological contract. In: Academy of Management Review. 2003, vol. 28 (4), pp. 571-586. ISSN 1930-3807.

24. SHORE, L.M., BARKSDALE, K. Examining degree of balance and level of obligation in the employment relationship: a social exchange approach. In: Journal of Organizational Behavior. 1998, vol. 19, pp. 731744. ISSN 1099-1379.

25. MCLEAN PARKS, J., KIDDER, D.L. "Till death us do part...". Changing work relationships in the 1990s. In: C.L. COOPER, D.M. ROUSSEAU. Trends in Organizational Behavior. Chichester: John Wiley \& Sons, 1994, vol. 1, pp. 111-136.

26. COOPER, C.L. The changing psychological contract at work. In: European Business Journal. 1999, vol. 11, pp. 115-118. ISSN 0955-808X. 
27. CAVANAUGH, M.A., NOE, R.A. Antecedents and consequences of relational components of the new psychological contract. In: Journal Organizational Behavior. 1999, vol. 20 (3), pp. 323-340. ISSN 10991379.

28. GUEST, D.E. The psychology of the employment relationship: An analysis based on the psychological contract. In: Applied Psychology: An International Review. 2004, vol. 53 (4), pp. 542-544. ISSN 14640597.

29. BRIDGES, W. The end of the job. In: Fortune. 1994, vol. 19, pp. 62-74.

30. GUEST, D.E., CONWAY, N. Peering into the black hole: the downside of the new employment relations in the UK. In: British Journal of Industrial Relations. 1999, vol. 37 (3), pp. 367-389. ISSN 1467-8543.

31. ROUSSEAU, D.M. Changing the deal while keeping the people. In: Academy of Management Executive. 1996, vol. 10 (1), pp. 50-59. ISSN 1079-5545.

32. HENDRY, C., JENKINS, R. Psychological contracts and new deals. In: Human Resource Management Journal. 1997, vol. 7, pp. 38-44. ISSN 1748-8583.

33. MUCHINSKY, P.M. Psychology Applied to Work. Belmont, 2003.550 p. ISBN 0534596258.

34. HERRIOT, P., PEMBERTON, C. New Deals: The Revolution in Managerial Careers. Chichester: Wiley, 1995. ISBN 978-0471957997.

35. HANDY, C. The Age of Unreason. Cambridge MA: Harvard Business School Press, 1989. 278 p.

36. HERRIOT, P., PEMBERTON, C. New Deals: The Revolution in Managerial Careers. Chicester: John Wiley\&Sons, 1995. ISBN 978-0471957997.

37. FARMER, S.M., FEDOR, D.B. Volunteer participation and withdrawal: A psychological contract perspective on the role of expectations and organizational support. In: Nonprofit Management \& Leadership. 1999, vol. 9, pp. 349-367. ISSN 1542-7854.

38. GUEST, D.E., CONWAY, N. Public and private sector perspectives on the psychological contract. Londra: CIPD, 2001. 104 p. ISBN 978-0852929506.

39. JAFFE, D. T., SCOTT, C.D. Rekindling work commitment and effectiveness through a new work contract. In: M.K. GOWING, J.D. KRAFT, J.C. QUICK. The New Organizational Reality: Downsizing, restructuring, and revitalization. Washington, DC: APA, 1997, pp. 185-205.

40. GUEST, D.E., CONWAY, N. Employer perceptions of the psychological contract. Londra: CIPD, 2001.80 p. ISBN 9780852928394.

41. ANDERSSON, L.M. Employee cynicism: an examination using a contract violation framework. In: Human Relations. 1996, vol. 49 (11), pp. 1395-1418. ISSN 1741-282X.

42. JOHNSON, J.L., O'LEARY-KELLY, A.M. The effects of psychological contract breach and organizational cynicism: not all social exchange violations are created equal. In: Journal of Organizational Behavior. 2003, vol. 24 (5), pp. 627-647. ISSN 0894-3796.

43. ARNOLD, J. The psychological contract: a concept in need of closer scrutiny? In: European Journal of Work and Organizational Psychology. 1996, vol. 5 (4), pp. 511-520. ISSN 1464-0643.

44. FREESE, C., SCHALK, R. Implications of differences in psychological contracts for human resource management. In: European Journal of Work and Organizational Psychology. 1996, vol. 5 (4), pp. 501-509. ISSN 1359-432X.

45. ROBINSON, S.L., MORRISON, E.W. The development of psychological contract breach and violation: a longitudinal study. In: Journal of Organizational Behavior. 2000, vol. 21 (5), pp. 525-546. ISSN 10991379.

46. GUEST, D.E. The psychology of the employment relationship: An analysis based on the psychological contract. In: Applied Psychology. 2004, vol. 53 (4), pp. 541-555. ISSN 1464-0597.

47. ROBINSON, S.L., KRAATZ, M.S., ROUSSEAU, D.M. Changing obligations and the psychological contract: A longitudinal study. In: Academy of Management Journal. 1994, vol. 37 (1), pp. 137-152. ISSN 0001-4273.

48. ORGAN, D.W. The motivational basis of organizational citizenship behavior. In: Research in Organizational Behavior. 1990, vol. 12, pp. 43-72. ISSN 0191-3085.

49. ROUSSEAU, D.M. Psychological contracts in organizations: understanding written and unwritten agreements. Thousand Oaks, CA: Sage Publications, 1995. ISBN 9780803971059.

50. TURNLEY, W.H., FELDMAN, D.C. A discrepancy model of psychological contract violations. In: Human Resource Management Review. 1999, vol. 9 (3), pp. 367-386. ISSN 1053-4822.

51. MORRISON, E.W., ROBINSON, S.L. When employees feel betrayed: A model of how psychological contract violation develops. In: Academy of Management Review. 1997, vol. 22 (1), pp. 226-256. ISSN 0363-7425.

52. TURNLEY, W.H., FELDMAN, D.C. A discrepancy model of psychological contract violations. In: Human Resource Management Review. 1999, vol. 9 (3), pp. 367-386. ISSN 1053-4822. 
53. PINDER, C.C., HARLOS, K.P. Employee silence: quiescence and acquiescence as responses to perceived injustice. In: Research in Personnel and Human Resources Management. 2001, vol. 20, pp. 331-369. ISSN 0742-7301.

54. BROOKS, I., HARFIELD, T. Breaking the psychological contract: The effects of change-work on middle managers when implementing organizational change. In: Asia Pacific Journal of Human Resources. 2000, vol. 38 (3), pp. 91-103. ISSN 1038-4111.

55. APPELBAUM, S.H., CLOSE, G.T., KLASA, S. Downsizing: An examination of some success and more failures. In: Management Decision. 1999, vol. 37 (8), pp. 424-437. ISSN 0025-1747.

56. NIXON, R.D., HITT, M.A. et al. Market reactions to announcements of corporate downsizing actions and implementation strategies. In: Strategic Management Journal. 2004, vol. 25 (11), pp. 1121-1129. ISSN 1097-0266.

57. STAVROU, E., KASSINIS, G., FILOTHEOU, A. Downsizing and stakeholder orientation among the Fortune 500: Does family ownership matter? In: Journal of Business Ethics. 2007, vol. 72, pp. 149-162. ISSN 01674544.

58. VAHTERA, J., KIVIMAKI, M., PENTTI, J. Effect of organizational downsizing on health of employees. In: Lancet. 1997, vol. 350, pp. 1124-1128. ISSN 0140-6736.

59. MANSON, B.J. The impact on employee morale and productivity. New York: Garland Publishing, 2000. 188 p. ISBN 9781315053769.

60. BURKE, R. LEITRER, M.P. Contemporary organizational realities and professional efficacy: Downsizing, reorganization, and transition. In: P. DEWE, M.P. LEITER, T. COX. Coping, health and organisations. Londra: Taylor \& Francis, 2000, pp. 241-262.

61. LEWIN, J.E. The effects of downsizing on organisational buying behaviour: An empirical investigation. In: Journal of the Academy of Marketing Science. 2001, vol. 29 (2), pp. 151-164. ISSN 1552-7824.

62. MONE, M. Relationships between self-concepts, aspirations, emotional, responses, and intent to leave a downsizing organisation. In: Executive Excellence. 1999, vol. 11 (7), pp. 12-13.

63. ARMSTRONG-STRASSEN, M. Determinants of how managers cope with organisational downsizing. In: Applied Psychology: An International Review. 2006, vol. 55 (1), pp. 1-26. ISSN 1464-0597.

64. CARBERY, R., GARAVAN, T.N. Organisational Restructuring and Downsizing: Issues Related to Learning, Training and Employability of Survivors. In: Journal of European Industrial Training. 2005, vol. 29 (6), pp. 488-508. ISSN-0309-0590.

65. KINNIE, N., HUTCHINSON, S., PURCELL, J. Downsizing: is it always lean and mean? In: Personnel Review. 2000, vol. 27 (4), pp. 296-311. ISSN 0048-3486.

66. KOEBER, C. Corporate restructuring and the middle class: The process and meaning of worker displacement in the new economy. In: Qualitative Sociology. 2002, vol. 25 (2), pp. 217-246. ISSN 01620436.

67. BROCKNER, J., WIESENFELD, B. et al. The effects on layoff survivors of their fellow survivors' reactions. In: Journal of Applied Social Psychology. 1997, vol. 27 (10), pp. 835-863. ISSN 1559-1816.

68. THORNHILL, A.S., MARK, N.K. The meanings, consequences and implications of downsizing and redundancy: a review. In: Personnel Review. 1998, vol. 27, pp. 271-295. ISSN 0048-3486.

69. CAMERON, K.S. Investigating organisational downsizing-fundamental issue. In: Human Resource Management Journal. 1994, vol. 33 (2), pp. 183-188. ISSN 1748-8583.

70. PARKER, S.K., CHMIEL, N., WALL. T.D. Work characteristic and employee well-being within a context of strategic downsizing. In: Journal of occupational health psychology. 1997, vol. 2 (4), pp. 289-303. ISSN 1076-8998.

71. HERRIOT, P. The Career Management Challenge: Balancing Individual and Organisational Needs. Londra: Sage, 1992.192 p. ISBN 978-0803986558.

72. LAWLER, E.E., MOHRMAN, S.A. High-involvement management. In: Personnel. 1989, vol. 66 (4), pp. 2631.

73. ARMSTRONG, M. A Handbook of Human Resources Management Practice. Londra: Kogan Page, 1991. [Accesat 29.03.2019]. Disponibil:

https://www.academia.edu/11376756/Handbook.of.Human.Resource.Management.Practice_10th

74. KANTER, R.M. Change in the global economy: an interview with Rosabeth Moss Kanter. In: European Management Journal. 1994, vol. 12 (1), pp. 1-9. ISSN 0263-2373.

75. O'REILLY, B. The new deal: what companies and employees owe one another. In: Fortune. 1994, june 13, pp. 28-33.

76. LESTER, T. Managing People in Europe, Facing the Human Resource Challenge of Leaner Companies. London: The Economist Intelligence Unit, 1994. 
77. HILTROP, J.M. The changing psychological contract: the human resource challenge of the 1990s. In: European Management Journal. 1995, vol. 13 (3), pp. 286-294. ISSN 0263-2373.

78. LOUIS, M.R. Surprise and sense making: what newcomers experience in entering unfamiliar organizational settings. In: Administrative Science Quarterly. 1980, vol. 25 (2), pp. 226-251. ISSN 19303815.

79. PFEFFER, J. Competitive Advantage through People: unleashing the power of the work force. Boston: Harvard Business School Press, 1994. 288 p. ISBN 0875844138.

80. BURACK, E.H., MATHYS, N.J. Human Resource Planning: a pragmatic approach to manpower staffing and development. 2 end edition. Lake Forest: Brace-Park Press, 1987. 422 p. ISBN 978-0942560015.

81. MILLWARD, L.J., BREWERTON, P.M. Contractors and their psychological contracts. In: British Journal of Management. 1999, vol. 10 (3), pp. 253-274. ISSN 1467-8551.

82. ASELAGE, J., EISENBERGER, R. Perceived organizational support and psychological contracts: a theoretical integration. In: Journal of Organizational Behavior. 2003, vol. 24 (5), pp. 491-509. ISSN 1099-1379.

83. PEEL, S., INKSON, K. Economic deregulation and psychological contracts: the New Zealand experience. In: D.M. ROUSSEAU, R. SCHALK. Psychological Contracts in Employment: International Perspectives. Thousand Oaks, CA: Sage Publications, 2000, pp. 195-212. ISBN 9780761916819.

84. PATTERSON, F. Developments in work psychology: Emerging issues and future trends. In: Journal of Occupational and Organizational Psychology. 2001, vol. 74 (4), pp. 381-390. ISSN 2044-8325.

85. COYLE-SHAPIRO, J.A., KESSLER, I. Consequences of the psychological contract for the employment relationship: A large scale survey. In: Journal of Management Studies. 2000, vol. 37 (7), pp. 903-930. ISSN 1467-6486.

86. BRIDGES, W. JobShift: How to prosper in a workplace without jobs. St Leonards, N.S.W.: Allen\&Unwin, 1995. 276 p. ISBN 978-0201489330.

87. GUEST, D.E., CONWAY, N. Communicating the psychological contract: an employer perspective. In: Human Resource Management Journal. 2002, vol. 12 (2), pp. 22-38. ISSN 1748-8583.

88. TURNLEY, W.H., FELDMAN, D.C. The impact of psychological contract violations on exit, voice, loyalty, and neglect. In: Human Relations. 1999, vol. 52 (7), pp. 895-922. ISSN 0018-7267.

89. DIOTAIUTI, P. Decision Making e Autoregolazione. Frosinone: Teseo Editore, 2010. 250 p. ISBN 9788896476369.

90. APPELBAUM, S.H., EVERARD, A., HUNG, L.T. Strategic downsizing: critical success factors. In: Management Decision. 1999, vol. 37 (7), pp. 535-552. ISSN 0025-1747.

91. TURNLEY, W.H., FELDMAN, D.C. The impact of psychological contract violations on exit, voice, loyalty, and neglect. In: Human Relations. 1999, vol. 52 (7), pp. 895-922. ISSN 1741-282X.

92. KICKUL, J. When organizations break their promises: employee reactions to unfair processes and treatment. In: Journal of Business Ethics. 2001, vol. 29, pp. 289-307. ISSN 1573-0697.

93. KESSLER, I., UNDY, R. The new employment relationship: examining the psychological contract. London: IPD, 1996. 54 p. ISBN 9780852926581.

\section{ARTICLE HISTORY}

Received 11 September 2019

Accepted 30 October 2019 


\title{
THE EXPERIENCE OF WORK-LIFE BALANCE FACED BY MOTHERS WITH PRESCHOOL CHILDREN
}

\author{
Inga CHISTRUGA-SINCHEVICI ${ }^{1}$, PhD in Sociology, \\ National Institute for Economic Research, Republic of Moldova \\ Natalia BARGAN2, \\ National Institute for Economic Research, Republic of Moldova
}

DOI: https://doi.org/10.36004/nier.es.2019.2-07

JEL Classification: J10, J13, J19

UDC: 614.3

\section{ABSTRACT}

The article presents the results of the sociological study "Parents between the need to work and family responsibilities" (in baze on 1047 questionnaires with mothers with preschool children and 20 in-depth sociological interviews), conducted by the Center for Demographic Research of NIER. The purpose of the study consisted in analyzing the particularities of reconciling the family life and the professional life of mothers with preschool children, in highlighting the difficulties they face in reintegrating into the labour market after child care leave and in determining the factors that contributes to facilitating the process of balancing family and professional life. The results of the study revealed that families face difficulties in establishing and maintaining a balance between many and sometimes contradictory demands offamily and professional life. The interviewed mothers highlighted a high level of motivation to be employed, but the defining reason for returning to the labor market is the need to earn money. Depending on the professional and family orientations, mothers with preschool children can be divided into three categories: mothers who want to combine the work with raising children (65\%), mothers who intend to make a career but do not forget about children (21.3\%) and mothers who prefer to be housewifes and take care of children (13.7\%). Although the support of the husband moderates the relationship between family and professional responsibilities, the results of the study have shown that there is a tendency for women to take full responsibility of the household and child care. The lack of quality care and education services for preschool children, the absence of flexible work programs but also the unequal distribution offamily responsibilities contribute to making the work-family life balance a predominant problem.

Keywords: life-work balance, work-family conflict, sociological study.

In articol sunt prezentate rezultatele studiului sociologic „Părinții între necesitatea de a munci și responsabilitățile familiale" (în baza la 1047 de chestionare cu mame cu copii de vârstă preșcolară și 20 de interviuri sociologice aprofundate), desfășurat de CCD al INCE. Scopul studiului a constat în analiza particularităților de reconciliere a vieții de familie și a vieții profesionale a mamelor cu copii de vârstă preșcolară, în evidențierea dificultăților cu care se confruntă la reintegrarea în câmpul muncii după aflarea în concediul de îngrijire a copilului și în determinarea factorilor ce contribuie la facilitarea procesului de echilibrare a vieții familiale și profesionale. Rezultatele studiului au relevat că familiile se confruntă cu dificultăți în stabilirea și menținerea unui echilibru între numeroasele și uneori contradictoriile solicitări ale vieții de familie și a celei profesionale. Mamele intervievate au evidențiat un nivel ridicat de motivație pentru a fi încadrate în câmpul muncii, însă motivul determinant pentru a reveni în câmpul muncii este necesitatea de a câstiga bani. În funcție de orientările profesionale și familiale, mamele cu copii de vârstă preșcolară pot fi divizate în trei categorii: mame care își doresc să combine serviciul cu creșterea copiilor (65\%), mame care intenționează să facă carieră, dar să nu uite nici de copii (21,3\%) și mame care preferă să fie casnică și să aibă grijă de copii $(13,7 \%)$. Deși sprijinul soțului moderează relația între responsabilitățile familiale și cele profesionale, rezultatele studiului au evidențiat că se păstrează tendința ca femeile să-și asume întreaga responsabilitate a gospodăriei și a îngrijirii copiilor. Lipsa serviciilor calitative de îngrijire și educație a copiilor

1 @ Inga CHISTRUGA-SÎNCHEVICI, $\bowtie$ i_sinchevici@yahoo.com

2 @ Natalia BARGAN, $₫$ nataly_bargan@gmail.com 
de vârstă preșcolară, absența programelor flexibile la locul de muncă, dar și continua distribuție inegală a responsabilităților familiale dintre soți determină faptul că îmbinarea rolurilor profesionale cu cele familiale rămâne o problemă predominantă.

Cuvinte-cheie: echilibrul viață-muncă, conflictul muncă-familie, studiul sociologic.

В статье представлены результаты социологического исследования «Родители между необходимостью работать и семейными обязанностями» (на основе 1047 анкет для матерей с детьми дошкольного возраста и 20 социологических глубинных интервью), проведенного Центром демографических исследований НИЭИ. Цель исследования состояла в том, чтобы проанализировать особенности совмещения семейных ролей и профессиональной деятельности матерей с детьми дошкольного возраста, выявить трудности, с которыми они сталкиваются при реинтеграции на рынке труда после отпуска по уходу за ребенком, и определить факторы, способствующие сбалансированности семейной и профессиональной жизни. Результаты исследования показали, что семьи сталкиваются с трудностями в установлении и поддержании определённого баланса между многочисленными, а порой и противоречивыми запросам семьи и требованиями профессиональной деятельности. Опрошенные матери продемонстрировали высокий уровень мотивации для включения в рынок труда, при этом определяющей причиной возвращения на рынок труда является необходимость зарабатывать деньги. В зависимости от профессиональной и семейной ориентации, матерей с детьми-дошкольниками можно разделить на три категории: матери, которые желают совмещать работу с воспитанием детей (65\%), матери, ориентированные на карьеру, не забывая приэтом о детях (21 3\%) и матери, предпочитающие быть домохозяйками и посвятить себя заботе о детях (13,7\%). Несмотря на то, что поддержка супруга способствует сочетанию трудовой деятельности с выполнением семейных обязанностей, результаты исследования показали, что женщины по-прежнему склонны нести полную ответственность за домашнее хозяйство и заботу о детях. Отсутствие качественных услуг по уходу и воспитанию детей дошкольного возраста, гибких программ на рабочих местах, а также продолжающееся неравное распределение семейных обязанностей между супругами способствуют тому, что баланс между работой и личной жизнью остается доминирующей проблемой.

Ключевые слова: баланс между работой и семейной жизнью, конфликт между работой и семьей, социологическое исследование.

INTRODUCTION. Family and work are two important focal points in adult's life and are interconnected. In today's society full of responsibilities and commitments, the relationship between work and family life has become a predominant problem, given that the balance between these aspects is one of the fundamental conditions for increasing the return on human capital.

The deep interest in the relationship between professional and family lifes is due to sociodemographic factors - increase in the number of couples in which both partners are employed, in the number of single-parent families, but also due to the emphasis on the importance of professional identity for women. In addition, the fact that the age of formation of families is constantly increasing contributes to the emergence of the phenomenon of the "intermediate" or "sandwich" generation, consisting of those who have to take care of an elderly relative while raising small children, studies show that women are more likely than men to experience this situation [20, ST-AMOUR N. ș.a., 2007].

Difficulties in maintaining a balance between professional and family lifes are also determined by the reduced child care and education facilities, the system of child care and education not beeing sufficiently developed; by the rigidity of work schedules that do not allow to achieve a balance between professional and personal life and the continuous unequal distribution of family tasks between husband and wife, family responsibilities interfering with career development.

The tasks of combining professional and family roles are today the objectives of state social policy. The Republic of Moldova has a developed legislative framework and actively participates in international treaties that prohibit discrimination in employment. In the National Strategic Program on Demographic Security of the Republic of Moldova (2011-2025) it is specified that in order to develop measures to solve family problems, it is proposed to promote the father's broader involvement in raising children by granting paid leave of paternity and leave for raising the child with special provisions for fathers; establishing a flexible work program to facilitate the process of raising children; ensuring equal payment / remuneration for women and men. 
Also, several changes were made to the legal framework. According to the amendments to the Law on temporary disability allowances and other social security benefits from July 1, 2019, parents who receive child care allowances but decide to work will receive both the allowance and salary. The child care leave has been reformed by increasing the child care allowance commensurate to the reduction of the period of care leave. Other changes are related to reducing unpaid care leave from 6 years to 4 years and completing the Labor Code with art. $124^{1}$ Parental leave.

THE THEORETICAL FRAMEWORK OF THE STUDY. The key concepts used in the present scientific paper are: work-family life balance, work-family conflict and family-work conflict.

The syntagm "work/life balance" was proposed in 1985, although its use in everyday language has been sporadic for several years. The balance between these two components means allocating an equal interval of time to both segments of life, avoiding the disadvantage of one of them. This balance does not come by itself and is the result of a good organization and discipline, varying according to individual, family, organizational and societal characteristics. The conceptualization of work-family balance as a conflict is related to the deficit hypothesis, according to which individuals possess a certain amount of time and energy that must be distributed between different roles they play.

Researchers Greenhaus J. and Beutell N. [12, 1985] had an important role in conceptualizing the term of conflict between work and family, establishing that conflict can have three forms: based on time, tension and behavior. Time-based conflict arises when the pressures in one area affect the fulfillment of the requirements associated with the other one, the employees do not have enough time to successfully or comfortably complete all the tasks associated with their work and family. Time-based conflicts arise when the demands imposed by different roles make time management difficult. Moreover, concerns about one role may affect the readiness to perform tasks related to another role, even if the person is physically present. Tension-based conflict results when stress generated during the performance of a role affects how a person meets the requirements of other roles. Behavior-based conflict refers to the phenomenon whereby a behavior specific to one role is incompatible with the behavior required of another role. Certain characteristics that are appreciated in the world of work, such as objectivity and aggressiveness, may be incompatible with family needs and expectations. There is a need to adjust the behaviors to the context in which the person is.

Some researchers like Sulea C., Virga D., Galben N. have pointed out that women experience more work-family conflict based on behavior and family-work conflict based on tension. That is, women cannot take on the successful behavioral strategies that they adopt at work to solve family problems, and the tensions in their personal lives tend to generate conflicting states at work. Men experience, to a greater extent, work-family conflict based on time. That is, they spend too much time at work and have no time resources for family activities [23, SULEA C., VÎRGĂ D., GALBEN N., 2010].

In the specialized literature two directions of the conflict between work and family are distinguished: the work-family conflict and the family-work conflict. Work-family conflict occurs when work-related activities intersect with household responsibilities or when work-related stress has negative effects on family behaviors. The conflict between family and work arises when family responsibilities impede work activities or when family stress has negative effects on work performance. Although closely related, they are conceptually and empirically distinct constructs. conflict:

The analysis of literature [1, AHMAD A., 2008] in the field allowed us to identify several sources of

1. from the workplace: the ambiguity of roles in the workplace; overcharging; organizational culture; frequent job related trips; style of time management practiced in the organization; type of job position; job flexibility.

2. from the perspective of personal beliefs and aspirations: the lifestyle; perfection in work; emotional health problems; values of the role of life.

3. from the family: needs regarding the assurance of financial or material resources; maintaining and sustaining interpersonal relationships; involvement in raising and educating children; health problems of a family member; number of children; life cycle stage; child care arrangements.

An important researched aspect concerns the specific factors related to the evolution of technologies with implications in generating conflicts between work and family. In the contemporary professional life, new technologies allow the accomplishment of professional tasks not only in different locations, but also 
outside the official working time. The pressure to meet increasingly tight deadlines, as well as the need to be permanently available to clients, has led to the extension of the professional life towards the family [25, ZAHARIA V., GAVRILOAIEI S., 2015]. A study from the Russian Federation also highlighted this issue by pointing out that mobile devices allow employees to respond quickly, constantly accessing and sharing information, contributing to increased employee productivity and encouraging cooperation between them. But the continuous participation in the professional life, in the long term, reduces the productivity because workers do not have time to rest and to recover and the professional exhaustion increases. Thus appeared the "right to disconnect", giving the person the opportunity to "disconnect" from the workplace, from the use of electronic communications, such as emails and messages after the end of the work day [22, SON KH. I., CHERNOVA ZH., 2018].

Data from studies also show that, in general, young people are those who face difficulties in balancing work and family. Therefore, young people represent the group of employees who most likely seems to be affected by the work-family conflict. Many of them being newly married and early in their professional careers have not yet developed the skills to effectively balance the tasks associated with these roles - the parental/marital and the professional one. This fact indicates the need for more organizational support in this regard [18, PLATON C., 2016].

Researchers believe that the conflict between work and family has become an important area of research for organizations because of the negative effect these conflicts have on the behavior of employees at work and at home [11, GRANDEY A., CROPANZANO R., 1999; 20, ST-AMOUR N. ș.a., 2007; 24, YOUNGCOURT S., HUFFMAN A., 2005]. The consequences of the conflict between work and family life are complex, reflecting on:

- the employee: high level of stress, physical and emotional health problems (depression, anxiety), risky behaviors (alcohol consumption), increased marital stress, low career satisfaction, tension, irritability, frustration, vulnerability, insecurity and poor work performance.

- the employee's children: behavioral and emotional problems.

- at the organizational level: low fidelity to the company, increased interest in changing the job as a "method" for resolving conflicts, increasing staff turnover, absenteeism and high costs generated by health problems of employees/medical leave, low productivity [2, 2019].

The problems of reconciling family and professional life contribute to the emergence of the "delayed maternity" phenomenon, meaning that more women employed on the labor market are less likely to become mothers at a younger age. Conciliation problems are factors that prevent couples from having many children, thus contributing to lower birth rates. A low birth rate has a negative influence on economic growth as well as on the stability of social protection systems. International comparisons indicate a positive correlation between an efficient labor market presence and higher fertility (for example in France and Sweden) [8, 2004].

Recent studies in the field have also focused on studying the wage penalty for motherhood due to the difficulties of reconciling family and professional life. It has been established that the motherhood penalty increases with the number of children, especially young children [10, DAVIESA R., GAE"LLE P., 2005; 17, PILAR CASAL M., BARHAM B., 2013]. This penalty arises because with the birth of children women interrupt their work experience. Another reason is that maternity and household tasks can leave women exhausted while working, resulting in decreased productivity. Some women might give up work with higher wages in favor of family-friendly jobs that allow them to work fewer hours and spend more time at home. Some researchers - Anderson, Binder, and Krause (2002) have established that the motherhood penalty for lower-skilled workers is minimal, while mothers with higher education have a $15 \%$ wage penalty [17, PILAR CASAL M., BARHAM B., 2013]. Other studies have also shown that mothers with higher education receive a "fine" of 1.5 times higher than those without higher education. The difference in remuneration for mothers with higher education appears after the birth of the first child, while among the women without education, starting from the second birth [4, BIRYUKOVA S., MAKARENTSEVA A., 2017].

The theoretical-methodological basis consists of: conflict theory that emphasizes the dynamic nature of family life and the role of external factors (economy, politics, social structure); development theory, according to which the family goes through several stages of the family life cycle and the gender theory, according to which the conceptions and ideas regarding the family life of men are different from those of women, etc.

In the Republic of Moldova, this subject remains insufficiently exploited. In the 2015-2018 period the project "Interferences between professional work and private life. Intercultural aspects, local experiences 
and intervention strategies" was carried out within the Faculty of Psychology of the Moldova State University. Within this project, various aspects related to the relationship between the professional and family life of employees in the Republic of Moldova were investigated, but from a psychological perspective.

METHODOLOGY OF THE STUDY. The article is elaborated on the basis of the qualitative sociological study "Parents between the need to work and family responsibilities" carried out during August - October 2018 by the Center for Demographic Research, NIER, during which 20 sociological interviews were conducted with mothers with children of preschool age (up to 6 years). Also, the article is based on the data of the quantitative study "Parents between the need to work and family responsibilities" (1047 questionnaires with mothers with preschool children), carried out during February-March 2019. It was opted to conduct the study only in Chisinau for several reasons: persistence of demographic problems: increase in the age of women at childbirth; intensification of the phenomenon of postponement of childbirth; lack of quality preschool education services, especially for young children; in most families both partners are employed; increase in the number of single parent families; concentration of young population, young families, families with young children; extensive employment opportunities; high level of education of the female population.

The purpose of the study consisted in analyzing the particularities of reconciling the family life and the professional life of mothers with preschool children, in highlighting the difficulties they face in reintegrating into the labour market after child care leave and in determining the factors that contributes to facilitating the process of balancing family and professional life.

The general hypothesis of the study refers to the fact that the relationship between the professional and family life of mothers with preschool children is conditioned by the accessibility of the preschool education services, economic and psychosocial resources of the family, individual resources (education) and the flexibility of work programs.

Characteristics of the sample. Out of the total sample, $30 \%$ of mothers had children up to 3 years old and the rest between 3 and 7 years. Depending on the level of training 9.1\% of the respondents had gymnasium and secondary school education, 17.9\% post-secondary education (college, professional school), 5.6\% lyceum and 67.3\% - higher education. Depending on the occupational status - $59.7 \%$ were employees; private entrepreneur - $3.6 \%$, self-employed $6.6 \%$, unemployed $11.2 \%, 1.2 \%$ - working abroad and $17.9 \%$ were on maternity leave or child care leave. Out of the total number of those employed, $45.3 \%$ worked in the public sector, $50.2 \%$ in the private sector and the rest in other sectors (4.5\%).

RESEARCH RESULTS. The interviewed mothers showed a high level of motivation to be employed. $45.2 \%$ wanted/want to start working again before the child is 3 years old. But the main reason for returning to the labor market is the need to earn money (Fig. 1). "If there would be someone to support us, I would stay up to 3 years at home with the child. I am sorry for him, when I have to go to work, he comes to me and does not want to leave me."

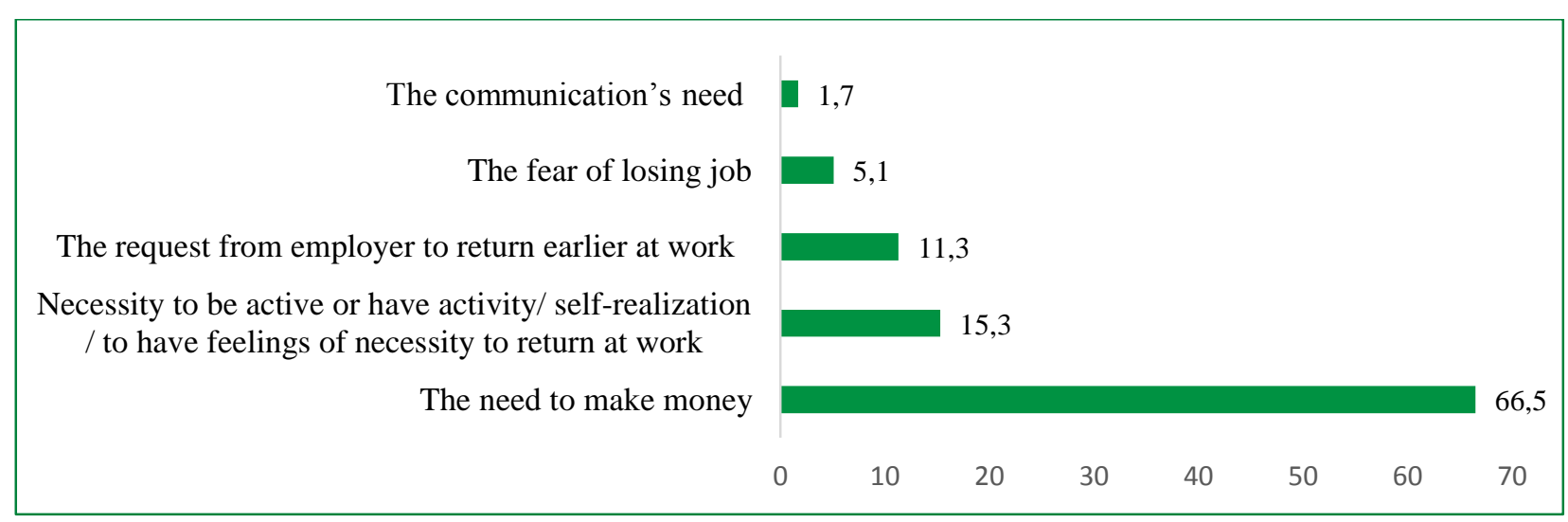

Figure 1. Reasons for early return to work after child care leave (in \%)

Source: The sociological study "Parents between the need to work and family responsibilities". 
The study allowed us to elaborate the typology of mothers with preschool children, according to their professional and family orientations, and their characterization:

Mothers who wish to combine the job with the raising of children (65\%) - most of them had the status of employees; work in the public sector; the activity stage is reduced; most of them return to work after child care leave. They appreciate that harmoniously combine work with family life. It was pointed out that most of them consider that they like to work, but do not want a too demanding professional activity. For mothers in this category, work is just a source of income for life.

Mothers who intend to make a career but do not forget about children (21.3\%) - usually have a higher education level; hold management positions; most of them are active in the private sector of the economy; the duration of child care leave is short. They appeal to particular child care services. They admit that are more dedicated to the field of activity than family life. They benefit from the necessary support/baking of the husband when returning to work. They are very satisfied with the work they are hired for.

Mothers who intend to be housewifes and take care of children (13.7\%) - most of them have gymnasium, secondary education; have three and more children; most of them occupy execution functions; predominantly work in the fields of manufacturing and trade; a significant number of them work up to 6 hours a day. More than half of them changed their jobs after child care leave. The husband, in most cases, is the main earner of the family and he is also the one who most often makes the household decisions. They admit that they are more dedicated to children and more satisfied with their parenting, to the detriment of their careers.

Totally $35.4 \%$ of those who returned to work changed their jobs, mainly those who worked in the private sector of the economy changed their jobs. This aspect highlights the persistence of increased insecurity in private companies. Thus, some women intentionally choose / give preference to the public sector to benefit from maternity leave, child care and medical leave. "I know that the rights to motherhood are not really respected in private companies, that is why I decided to work in public sector, where the rights of mothers with children are respected. My colleagues made it clear to me that if I want to have children in the future, then it would be better to leave from here. I have found that you cannot be a mother in private company in our country". "I better work in a state institution with a lower salary, but to be respected, to feel as human, and for individuals with more money being considered a money-making machine, which, if used, can be thrown away".

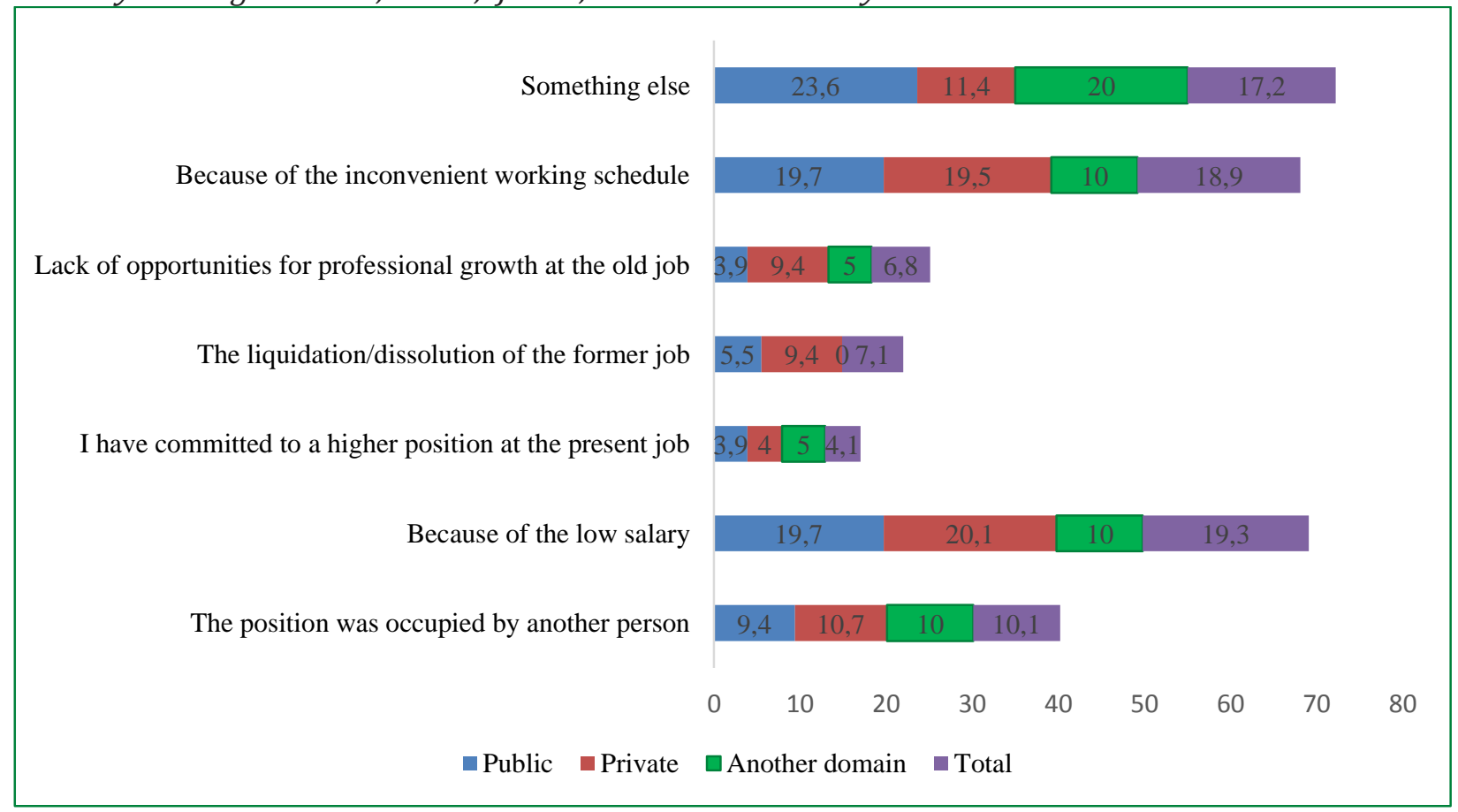

Figure 2. Causes of job change (in \%)

Source: The sociological study "Parents between the need to work and family responsibilities"

No. 2 / 2019 
The data in Fig. 2 emphasizes some problems that are attested in the private environment, such as occupying the position previously held by other persons contrary to the legal framework that ensures the retention of the job upon the return from the child care leave and the lack of prospects for professional growth. In some international studies [5, BUELENS M., BROECK H., 2007] it was also found that public sector workers face fewer conflicts between personal and professional life than private sector workers and also have a higher level of satisfaction with family life and more free time.

The results of the study also revealed the problem of the limited possibilities of part-time job for mothers. Thus, in some situations mothers wanted to integrate into the labour market from an earlier age of the child, opting for a part-time work, but in the absence of this possibility, they have to work full time or not at all. "Initially, I wanted to work part-time, that is 4 hours, but I was not allowed. I was told either full time, or not at all".

If we interpret the decision to work part-time as a voluntary one, then the increased possibility of benefiting from such a work arrangement can be viewed as an opportunity for women to earn income from an activity that can be combined with the fulfillment of the other responsibilities [16, LEOVARDIS C., NICOLAESCU C., 2011]. In some situations, part-time work helps women to balance their family and professional lives. In some studies it has been established that women who work part time report a higher level of happiness at home and a greater satisfaction with their children than women who work full time [14, HIGGINS C. et al., 2000].

To evaluate the indicators of family-work and work-family conflict, a literature review was performed using the scales proposed by Turkish researchers Gürcü Erdamar, Hüsne Demirel, which were translated and adapted. Each question was answered as Never (1), Rare (2), Occasional (3), Often (4) and Always (5). Given that the family is more important than the work, the value of the family-work conflict is higher than that of the work-family conflict, constituing 25.4 and 21.92 respectively.

Table 1

The value of work-family conflict

\begin{tabular}{|l|c|c|}
\hline $\begin{array}{l}\text { 1. Because I have many tasks and responsibilities at work, I } \\
\text { cannot spend enough time with my family }\end{array}$ & 2,66 & 1,086 \\
\hline $\begin{array}{l}\text { 2. Physical and mental fatigue at work makes it difficult to fulfill } \\
\text { my responsibilities at home }\end{array}$ & 2,72 & 1,043 \\
\hline $\begin{array}{l}\text { 3. Workplace fatigue decreases my patience with family } \\
\text { members }\end{array}$ & 2,38 & 1,073 \\
\hline $\begin{array}{l}\text { 4. Work assignments make me feel tired while fulfilling my } \\
\text { responsibilities at home }\end{array}$ & 2,66 & 1,052 \\
\hline $\begin{array}{l}\text { 5. I can't use the time for homework because of my service. I } \\
\text { always postpone doing the housework }\end{array}$ & 2,32 & 1,087 \\
\hline $\begin{array}{l}\text { 6. My professional life diminishes my efforts necessary to fulfill } \\
\text { my household responsibilities }\end{array}$ & 2,29 & 1,083 \\
\hline $\begin{array}{l}\text { 7. I continue to think at home about a problem I faced in the } \\
\text { workplace }\end{array}$ & 2,63 & 1,119 \\
\hline 8. A problem at work makes me stressed and nervous at home & 2,44 & 1,067 \\
\hline $\begin{array}{l}\text { 9. My duties and responsibilities in the workplace are a priority } \\
\text { of my family life }\end{array}$ & 1,82 & 1,158 \\
\hline Total & 21,92 & 9,76 \\
\hline
\end{tabular}

Source: The sociological study "Parents between the need to work and family responsibilities"

According to the study, mothers with higher level of education experienced a greater conflict between work and family than those without higher education. This can be explained by the fact that people with higher education work in jobs characterized by greater responsibility. 
The value of the family-work conflict

\begin{tabular}{|l|c|c|}
\hline $\begin{array}{l}\text { 1. My responsibilities at home diminish the time and effort I should } \\
\text { devote to professional activity }\end{array}$ & 2,01 & 0,970 \\
\hline $\begin{array}{l}\text { 2. Because I have too many responsibilities at home, I do not put } \\
\text { the work at the forefront }\end{array}$ & 2,22 & 1,075 \\
\hline $\begin{array}{l}\text { 3. My responsibilities at home create difficulties in my professional } \\
\text { life }\end{array}$ & 1,83 & 0,952 \\
\hline $\begin{array}{l}\text { 4. Family troubles and problems negatively affect my professional } \\
\text { life }\end{array}$ & 1,81 & 0,960 \\
\hline 5. A family problem makes me feel stressed and nervous at work & 2,07 & 1,006 \\
\hline 6. At work I continue to think of a problem I faced at home & 2,42 & 1,019 \\
\hline $\begin{array}{l}\text { 7. Certain situations I encounter at home (guests, illness, a child } \\
\text { problem) make my work difficult }\end{array}$ & 2,43 & 0,994 \\
\hline $\begin{array}{l}\text { 8. Domestic tasks reduce the time I have for sleep, which is } \\
\text { essential for my service }\end{array}$ & 2,55 & 1,140 \\
\hline 9. Because of my family responsibilities, I always go to work tired & 2,22 & 1,027 \\
\hline $\begin{array}{l}\text { 10. Due to my responsibilities in the family, I cannot participate in } \\
\text { certain activities related to my professional activity (meeting, } \\
\text { dinner, etc.) }\end{array}$ & 2,28 & 1,128 \\
\hline $\begin{array}{l}\text { 11. My family duties and responsibilities are above my } \\
\text { professional life. }\end{array}$ & 3,56 & 1,395 \\
\hline Total & 25,4 & 11,66 \\
\hline
\end{tabular}

Source: The sociological study "Parents between the need to work and family responsibilities".

The data in Fig. 3 shows that the value of conflict for both work-family and family-work components is higher for mothers who have children up to 3 years old than for mothers who have children from 3 to 7 years. Researcher Ahmad A. emphasized that work-family conflicts need to be investigated according to the stage of the family life cycle. Young children are dependent on parents, especially mothers, which explains this direct correlation [1, AHMAD A., 2008].

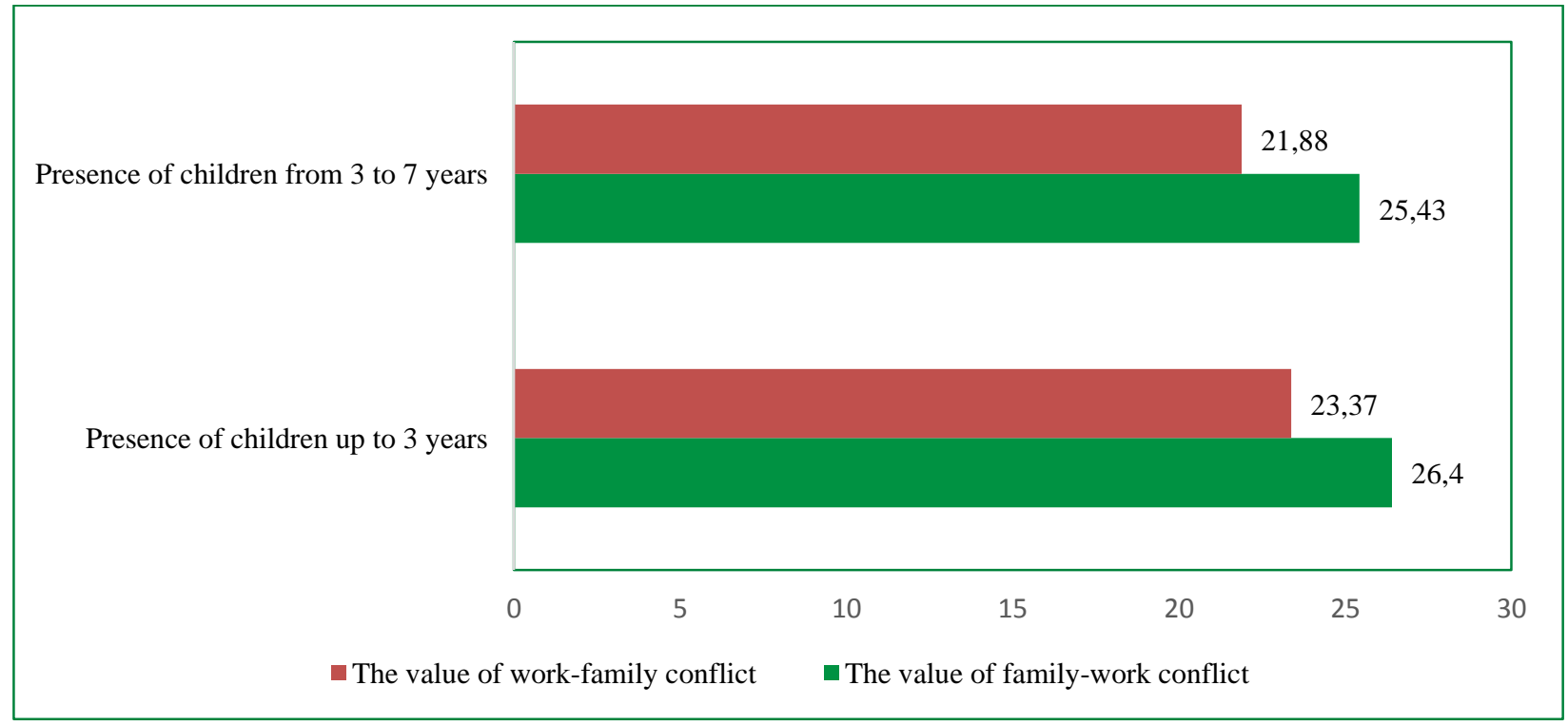

Figure 3. The value of family-work and work-family conflict depending on the age of children (in \%)

Source: The sociological study "Parents between the need to work and family responsibilities".

No. 2 / 2019 
The results of the author's study showed that women with young children from Chisinau municipality face the reluctance and inability of employers to offer them any conditions that would allow them to harmoniously combine family and professional life. Companies in the Republic of Moldova are still reluctant to create flexible work schedules. This is argued by the fact that $46.6 \%$ of interviewed mothers mentioned that they face the need to have a flexible working schedule (Fig. 4). The short and medium term flexibility is expected to solve the problems of episodic childhood diseases of children. "I feel very much the need to have a more flexible program, so that I can pay more attention and time to the care of the children. At my workplace I cannot benefit from such luxury in any form. We have very strict requirements. Probably, I should have another job." However, the flexibility of the work program is decisive in choosing a specific job, because the employees do not neglect their responsibilities towards the family.

Impossibility to have a needed flexible work schedule

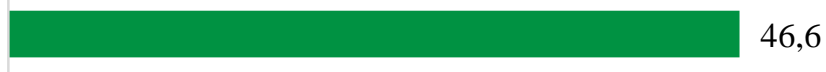

The necessity to stay over working hours program

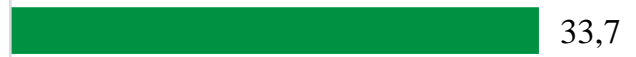

The employer's negative attitude regarding medical leave

Lack of opportunity to take vacation leave when needed / when you want

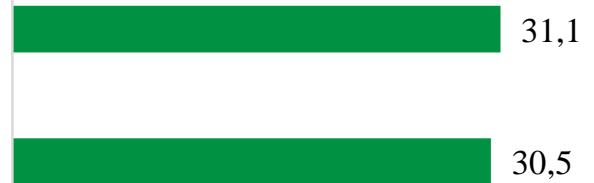

Impossibility to mack changes of working hours in unpredictable situations

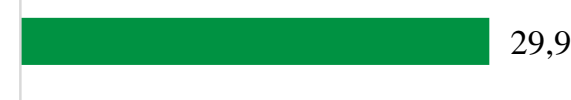

The technological working process at the job place cannot be interrupted

Lack of possibility to go in business / job trips

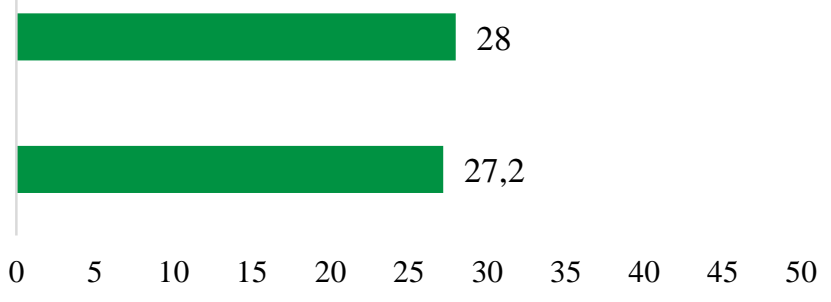

Figure 4. Situations faced by mothers in the workplace, (the total of answers always and often in \%)

Source: The sociological study "Parents between the need to work and family responsibilities".

One third of the respondents acknowledged that they were in the situation when they stayed late at work overtime. "There are certain periods, specific to the type of activity, due to which the work program lasts up to 10-12 hours daily." "I stay overtime sometimes because of the lack of staff and large workload."

$31.1 \%$ of surveyed mothers emphasized that they encountered at the workplace the employer's dissatisfaction with taking medical leave to care for their sick child. Concrete cases in which mothers face the impossibility of being on medical leave were presented within conducted interviews. "I could not take any medical leave, from my colleagues I understood that if I would take at least one I would not work anymore." The total number of days, during the last 3 months, in which the respondents were absent from work, being on child care leave constituted 4099. 279 mothers stated that they were on medical leave, on average, a mother was on medical leave for 14 days. $49.5 \%$ of the respondents mentioned that it happened in the last 3 months them to work, although they had to take medical leave due to the child's health. 
Another issue related to the provision of medical leave refers to the impossibility of mothers who work part-time to benefit in addition to the salary and the monthly allowance for child care to take this leave in case the child becomes ill. "I cannot take medical leave because I am on child care leave and also I work 7 hours. When the child becomes ill, the husband takes his medical leave so that we do not lose money."

The data from the qualitative study also highlighted the existence of impediments at work that make it difficult to create a harmonious balance between work and family:

The need to complete various registers, reports for the purpose of providing permission slip. "Right now I am going with the girl to do investigations. It is necessary to write in a special register and to ask permission from 3 heads every time. This is very unpleasant, it is the health of the child, I do not go to clinics just for a walk."

Restrictions of the legal framework. "If an accident occurs during working hours, even if it is not inside the company, it is considered an accident at work. We are responsible for the life and safety of our employees".

Compliance with hygiene and safety rules in the situation work from home. "We have to make sure the room is bright, the cables are ok. But we will not go and check in his house."

Insufficient legal regulation of the issues related to offering flexible programs and work from home. "The law does not allow, but also does not prohibit work from home."

These problems reveal that many organizations have very limited provisions regarding the reconciliation of family and professional life. Thus, there is still a long way to go for them to be considered "family friendly".

Child care services represent a determining factor in ensuring the balance between work and child care. Most children in preschool institutions are between 3 to 6 years old, this denotes the lack of the segment of services for the care of children under the age of 3 years. Only $56.1 \%$ of the respondents were confident that they can leave the small child in the care of someone, knowing that everything will be fine when they return from work.

The educational system in Chisinau is insufficiently developed to comprise all children of preschool age. Due to the under-financing of the preschool institutions, absolutely all the respondents acknowledged that within the institution attended by the child/children, financial sources are collected for repairs, endowment with furniture, household items, additional payment of personnel and other necessities. Due to the lack of confidence in the quality of preschool educational services, due to the shortage of well-trained specialists some parents access private educational institutions, but due to the high price, their number is limited.

The activity of babysitters/nannies is not sufficiently regulated in the Republic of Moldova, this is currently possible under the patent holder regime, and the obtaining of patent does not require compliance with a certain set of conditions that must be verified by the state when giving the patent (criminal record, studies, medical certificate, etc.).

$36.9 \%$ of interviewed mothers mentioned that a preschool child suffer if his mother works. The success of the mother in the implementation of the career has a socializing significance for the children, teaching them to treat a person with freedom of choice. On the other hand, lack of maternal attention can affect their personal development, complicating the relationship with the mother [3, BEREZOVSKAYA T., 2012]. Other studies have also shown that longer periods of maternity leave are generally associated with better health outcomes for mother and child [21, SKINNER N. CHAPMAN J., 2013]. In other research it is emphasized that the work activity of the mother has a different effect on the children: if the work brings satisfaction and the feeling of self-realization for the mother, the children not only do not suffer, but receive certain benefits (communication becomes more significant). On the contrary, if for mothers the work is nothing more than a means of earning for living, then being involved in different responsibilities, roles, overload, her dissatisfaction can create feelings of guilt, tension [9, KONOVALOVA A.M., 2011].

Progress towards a more equal distribution of child care and household tasks between women and men is slow, and the division of household and child care activities between men and women is very limited. "He says so, I'm a man, I make money. You are a mother, you stay at home and take care of children." "I do everything related to the house and kids, but the father makes money." At $70.6 \%$ of 
respondents the husband agreed with the idea of returning to work, at $65 \%$ the husband gave her the necessary help to return to work, and at $12.5 \%$ of respondents the husband considers that the work negatively affects the fulfillment of family responsibilities. This denotes the predominance of traditional values, according to which women should give priority to family responsibilities, while men should play the role of breadwinner in the family.

The data in Fig. 5 reveals that the daily division of family activities remains asymmetrical and very traditional, women being still responsible mainly for child care and household tasks. This is due to the cultural environment in which the family roles and obligations are defined. The tendency persist for women to take full responsibility of the household and the child, even working full time. But the husband's support moderates the relationship between work stress and the work-family conflict, so it is still necessary to promote the "responsible fatherhood" model [7, CHERNOVA ZH., 2012], that is, increasing the participation of men in the care and education of children.

Play or spend time with children, have fun together

Talk with children about their problems

Get kids out of kindergarten

Take kids to the kindergarten

Prepare the children for bedtime or watch for them.

Read the evening story to the children

Wash dishes

Clean the house

Wash toddlers

Feed young children

Take the kids to the doctor

Stay at home with sick children
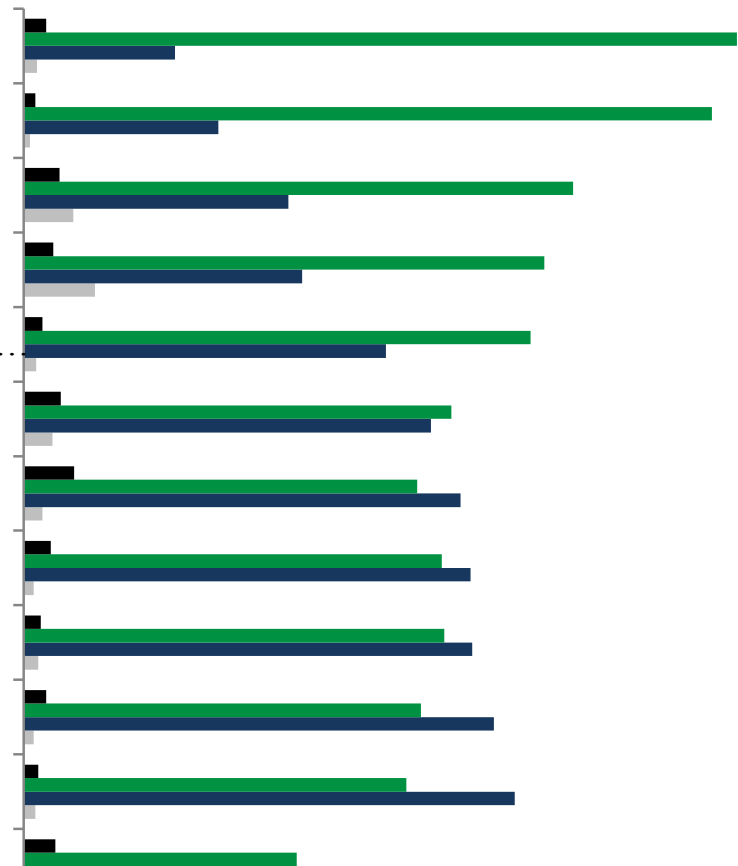

\section{Prepare food \\ Clean/wash clothes}

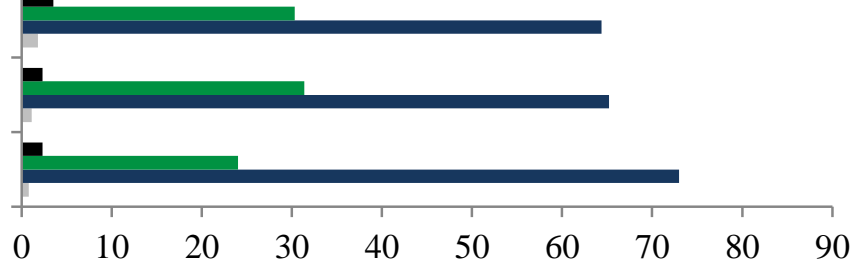

Somebody else $\quad$ Mom and Dad equally $\quad$ Always mother $\quad$ Always farther

Figure 5. Parents involvement in the education and care of children (in \%)

Source: The sociological study "Parents between the need to work and family responsibilities".

\section{CONCLUSIONS}

Finding a work-personal life balance for mothers is an essential issue for the well-being of children, as both poverty and lack of attention can harm the development of the child. A good balance reduces parental stress and therefore benefits both the parent-child relationship and the parentparent relationship.

Lack of nursery and early education services, inadequate conditions in some kindergartens make it difficult to combine professional and parental roles for mothers with young children. Some women choose to leave the labor market for a longer period of time than to face working conditions that do not allow them to balance their professional and family responsibilities. Thus, mothers are in 
a position to pay even a "fine" for motherhood.

The rigidity of the legal framework determines the impossibility of the employers to offer them some conditions that would allow them to harmoniously combine the family life with the professional one - flexible work programs, work from home, etc.

Mothers involved in the labor market face a conflict of role and in the absence of some facilities, the strategy for combining family life and work is to reduce fertility or delay it, meaning more women in the labor market are less likely to become mothers at a younger age.

\section{REFERENCES}

1. AHMAD A. Job, Family and Individual Factors as Predictors of Work-Family Conflict. 2008. [Accesat 21.11.2019]. Disponibil:https://www.researchgate.net/publication/260294449

_Job_Family_and_Individual_Factors_as_Predictors_of_Work-Family_Conflict

2. ASSOCIATION CANADIENNE POUR LA SANTÉ MENTALE. Le manque de conciliation vie personnelle - travail, facteur de risque. [Accesat 23.09.2019]. Disponibil:

https://www.mouvementsmq.ca/sites/default/files/3-manque.pdf

3. BEREZOVSKAÂ, T.P. Social'no-psihologičeskie osobennosti ženŝin, uspešnyh v kar'ere. V: Sem'â i ženŝina v sovremennom mire: social'nye i kul'turnye aspekty: meždunarodnaâ naučnaâ konferenciâ, 2 fevralâ 2012. Minsk, 2012, ss. 414-417. ISBN 978-985-552-151-9.

4. BIRÛKOVA, S., MAKARENCEVA, A. Ocenki «štrafa za materinstvo» v Rossii. V: Naselenie i èkonomika. 2017, Tom 1, № 1, ss. 50-70. ISSN 2658-3798.

5. BUELENS, M., BROECK, H. An Analysis of Differences in Work Motivation Between Public and Private Sector Organizations. In: Public Administration Review. 2007, vol. 67 (1), january, pp. 65-74. ISSN 1540-6210.

6. KALABIHINA, I., BIRÛKOVA, S. i dr. Sodejstvie professional'noj zanâtosti ženŝin s malen'kimi det'mi. Moskva, 2016. [Accesat 23.09.2019]. Disponibil: https://publications.hse.ru/en/books/198213850

7. ČERNOVA, Ž.V. Balans sem'i i raboty: politika i individual'nye strategii materej. In: Žurnal issledovanij social'noj politiki. 2012, Tom 10, № 3. [Accesat 23.10.2019]. Disponibil: https://cyberleninka.ru/article/n/balans-semi-i-raboty-politika-i-individualnye-strategii-materey

8. Conciliation entre Vie professionnelle et Vie familiale: rapport de synthèse de l'évaluation par les pairs. Berlin, 2004, 13-14 décembre. 35 p.

9. KONOVALOVA, A.M. Žiznennye strategii ženŝin: vybor i ego posledstviâ. V: Psihologiâ zrelosti i stareniâ, 2011, № 3, ss. 34-49. ISSN 0236-4999.

10. DAVIESA, R., GAE"LLE, P. The family gap in pay in Europe: A cross-country study. In: Labour Economics. 2005, vol. 12, pp. 469-486. ISSN 0927-5371.

11. GRANDEY, A., CROPANZANO, R. The Conservation of Resources Model Applied to Work-Family Conflict and Strain. In: Journal of Vocational Behavior. 1999, vol. 54 (2), april, pp. 350-370. ISSN 00018791.

12. GREENHAUS, J., BEUTELL, N. Sources of conflict between work and family roles. In: The Academy of Management Review. 1985, vol. 10, no. 1, pp. 76-88. [Accesat 01.11.2019]. Disponibil:

https://www.researchgate.net/publication/287011938_Sources_of_conflict_between_work_and_fa mily_roles_Academy_of_Management_Review_Vol

13. GREENHAUS, J.H., KAREN, M.C., SHAW, J.D. The relation between work - family balance and quality of life. In: Journal of Vocational Behavior. 2003, vol. 63, no. 3, december, pp. 510-531. ISSN 0001-8791.

14. HIGGINS, C., DUXBURY, L., JOHNSON, K. Part-time work for women: does it really help balance work and family? 2000. [Accesat 23.09.2019]. Disponibil:

https://www.researchgate.net/publication/255569927_PartTime_Work_for_Women_Does_It_Reall y_Help_Balance_Work_and_Family

15. ISUPOVA, O. Materinskaâ kar'era: deti i trudovye strategii. V: Sociologičeskie issledovaniâ. 2015, № 10, ss. 185-194. ISSN 0132-1625.

16. LEOVARDIS C., NICOLAESCU C. Raportul viață profesională-viață privată, preocupare de actualitate a UE în domeniul pieței muncii. In: Revista Română de Sociologie. Nr 1-2, București, 2011. [Accesat 21.10.2019]. Disponibil: http://revistadesociologie.ro/en/sites/default/files/07-cleovaridis.pdf

17. PILAR CASAL, M., BARHAM, B. Motherhood wage penalties and labour market segmentation: 
Evidence from Argentina. 2013, december. [Accesat 18.10.2019]. Accesat 18.10.2019].Disponibil: http.ist.psu.edu > viewdoc > download

18. PLATON, C. ș.a. Percepții privind angajamentul de rol și conflictul muncă-familie la angajații din Republica Moldova: studiu explorativ. In: Studia Universitatis Moldaviae. Seria Științe ale Educației. 2016, nr. 9, pp. 148-160. ISSN 1857-2103.

19. SAVINSKAÂ, O. Rabota i sem'â v žizni ženŝin s det'mi-doškol'nikami: opyt goroda. Moskva, 2008.192 s.

20. ST-AMOUR, N. et al. The difficulty of balancing work and family life: impact of the phisical and mental health of Quebec families. 2007, march. [Accesat 15.10.2019]. Disponibil: http://www.ncchpp.ca/docs/633-diffbalancingworkfamilylife.pdf

21. SKINNER, N. CHAPMAN, J. Work-life balance and family friendly policies. 2013. [Accesat 21.10.2019]. Disponibil: https://melbourneinstitute.unimelb.edu.au/assets/documents/hildabibliography/other-publications/2014/Skinner_etal_work_life_balance.pdf

22. SON, H.I., ČERNOVA, Ž.V. Mobil'nye ustrojstva kak sposob ustanovleniâ balansa meždu rabotoj i ličnoj žizn'û: oborotnaâ storona. 2018. [Accesat 15.10.2019]. Disponibil: https://monitoringjournal.ru/index.php/monitoring/article/view/551

23. SULEA, C., VÎRGĂ, D., GALBEN, N. Scala Conflict Muncă-Familie: Analiza proprietăţilor psihometrice ale versiunii în limba română. 2012. [Accesat 10.10.2019]. Disponibil: http://www.ohpedu.ro/articole/scala-conflict-munca-familie-analiza-proprietatilor-psihometriceale-versiunii-in-limba-romana-4/

24. YOUNGCOURT, S., HUFFMAN, A. Family-Friendly Policies in the Police: Implications for WorkFamily Conflict. 2005. [Accesat 13.11.2019]. Disponibil: http://www.apcj.org/documents/1_2_policies.pdf

25. ZAHARIA, V., GAVRILOAIEI, S. Flexibilitatea granițelor muncă-familie în context românesc. 2015, noiembrie. [Accesat 13.11.2019]. Disponibil:

https://www.researchgate.net/publication/290447085_Flexibilitatea_granitelor_muncafamilie_in_context_romanesc

\section{ARTICLE HISTORY}

Received 12 November 2019

Accepted 06 December 2019 


\title{
THE SYSTEM OF VALUES AND PERCEPTION OF TIME IN THE TRANSITIONAL SOCIETY: SOCIO-PSYCHOLOGICAL ISSUES AND PERSPECTIVES
}

\author{
Irina CAUNENCO1, PhD in Psychology, Associate Professor, \\ Institute of Cultural Heritage, Republic of Moldova \\ Lucia GASPER ${ }^{2}$, PhD in Psychology, Senior Researcher, \\ Institute of Legal, Political and Sociological Research, Republic of Moldova
}

DOI: https://doi.org/10.36004/nier.es.2019.2-08

JEL Classification: I25, I29, J15, J24

UDC: 316.6

\section{ABSTRACT}

The empirical study of the time and values system perception in different social ethnic and age groups offers the possibility to understand the potential subjectivity of groups in transitional society. The goal of the research was the study of time perception, values system in different age and ethnic groups in the transitional society. The methodological basis of our research is the systemic approach and social constructivism. Social groups were studied - age groups (adolescents, youngers, adults); ethnic groups (Gagauz people, Ukrainians, Bulgarians, Russians). In order to carry out the empirical research, standardized methods and semi-structured interview were applied: "The Scale of Time Attitudes" Nutten J.; semi-structured interview on time perception; the method elaborated by E. B. Fantalova. It was revealed that the groups of Russians, Bulgarians are characterized by a positive perception of present time, but the Gagauz people and Ukrainians perceived less positive the present time. Time perspective of these groups is short-from one year to five years - that can be an evidence of difficulties met by these groups in today transitional reality of the country. There were determined groups of youngers on time perception from optimistic to socialanxious (the given type, potential for migration). The study of values system of adolescent respondents from rural areas (most have parents working abroad) showed the importance of such values as health, happy family life and at the same time, the complexity of their basic needs' satisfaction.

Keywords: large social groups, time perspective, time perception, present time perception, ethnic groups, age groups, value, value system, transitional society, worldview, social time.

Studiul empiric al percepției timpului și a sferei valorice la diferite grupuri sociale-etnice, de vârstă - face posibilă înțelegerea potențialului subiectivității grupurilor într-o societate tranzitivă. Studiul a avut ca scop studierea percepției timpului, sferei valorice de către diferite grupuri de vârstă și etnice în societatea tranzitivă. Drept bază metodologică a studiului a fost abordarea sistemică și constructivismul social. Au fost studiate grupurile sociale de vârstă - adolescenți, tineri, adulți și etnice -găgăuzi, ucraineni, bulgari și ruşi. Pentru realizarea studiului empiric s-au aplicat tehnici standardizate și interviul semistructurat: "Scala atitudinilor de timp" de Nutten J., interviul semistructurat privind percepția timpului, metoda elaborată de E.B.Fantalova. S-a determinat că la grupurile de ruși și bulgari prevalează o percepție pozitivă a prezentului, pe când la găgăuzi și ucraineni fiind mai redusă. Perspectiva de timp a acestor grupuri este de scurtă durată, de la unu la cinci ani, ce poate indica dificultăți în depășirea perioadei de tranzitivitate la grupurile respective. Se disting grupuri de tineri în percepția timpului, de la optimiști la anxioși-social (un tip potențial de emigrare). Un studiu asupra sferei valorice a adolescenților respondenți din mediul rural (cu părinți plecați peste hotare) a dezvăluit prioritatea valorilor - sănătate, o viață de familie fericită și, în același timp, dificultatea în realizarea acestor valori.

Cuvinte-cheie: grupuri sociale mari, perspectiva de timp, percepția timpului, grupuri etnice, grupuri de vârstă, valori, societate tranzitivă, orientări valorice, imaginea lumii, timp social.

1 (C) Irina CAUNENCO, caunencoi@mail.ru

2 (C) Lucia GASPER, gasperlucia@mail.ru 
Эмпирическое исследование восприятия времени и ценностной сферы у этнических и возрастных социальных групп даёт возможность понимания потенциала субъектности групп в транзитивном обществе. Целью исследования явилось изучение восприятие времени, ценностной сферы разными возрастными и этническими группами в транзитивном обществе. Методологическая основа исследования: системный подход и социальный конструктивизм. Исследовались социальные группы - возрастные (подростки, молодёжь, взрослые); этнические (гагаузы, украинцы, болгары, русские). Для реализации эмпирического исследования были применены стандартизированные методики и полуструктурированное интервью: «Шкала временных установок» Нюттен Ж.; полуструктрированное интервью по восприятию времени; методика Е.Б.Фанталовой.

Выявлено, что у групп русских и болгар доминирует позитивное восприятие настоящего времени, тогда как у гагаузов и украинщев оно несколько ниже. Временная перспектива данных групп короткая, от года до пяти лет, что может свидетельствовать о сложностях прохождения периода транзитивности у данных групп. Выделены группы молодёжи по восприятию времени от оптимистического, до социально-тревожного (данный типпотенциал для эмиграции). Исследование ценностной сферы респондентов подросткового возраста из сельской местности, у которых большинство родителей находятся на заработках, выявило значимость ценностей - здоровья, счастливой семейной жизни, и в то же время сложности в их удовлетворении.

Ключевые слова: большие социальные группы, временная перспектива, восприятие времени, этнические группы, возрастные группы, ценности, транзитивное общество, ценностные ориентации, картина мира, социальное время.

INTRODUCTION. The research of large social groups in the period of transition presents a great interest for us, because the content of socially important features of human psychic are developed at macro-social level, where, from historical perspective, concrete social rules, values, attitudes and representations are formed, which in their turn are "delivered" to the individual through small groups and interpersonal communication [6, DILEGENSKIJ, G.G., 1994].

Large social groups are perceived as "natural" due to the length of their existence. The culturalpsychological originality of the given groups is formed historically, by the efforts of some generations which determine the orderliness, stability of group values, and rules of behavior and conduct. The agents of ethnic, gender-role, religious, and political socialization are represented by the members of immediate social environment.

The members of a large social group are linked by symbolic relations generated by the similarity of conditions, life style, values, experiences, and in ordinary circumstances such groups represent a community only in the consciousness of its members [5, BOGOMOLOVA, N.N. et al., 2002].

The research of large social groups is determined by the need of understanding the deep changes in a transitional society.

In the psychological content of the notion "society in transition" includes:

- fundamental social transformations;

- globalization that leads to the expansion of the space of interpersonal interactions;

- emphasis of social uncertainty related to frequent transformations of values, norms and standards;

- increase of the length of the time period of the socialization process, the intensification of re-socialization and current socialization;

- expansion of informational space, partially replacing intergenerational relations [13, MARCINKOVSKAÂ, T.D., 2015].

Nowadays, time categories play more and more a substantial role in forming the group identity and in the "imaginary communities" [1, ANDERSON, Benedikt., 2016].

In the conditions of transitional society, the individual and age groups need understanding and ways of owning personal time, because these represent an important condition of collective subjectivity. As "group attitude to time" we understand the peculiarities of perception, experience, awareness and management of time which are typical to the members of a certain social group [7, KRIVCOVA, S.V., 1997]. 
We define social time: firstly, as objective relations of antecedence, subsequence and simultaneity between people actions, social phenomena and processes; secondly, as subjective mirroring of these relations in the group consciousness [7, KRIVCOVA, S.V., 1997].

The social psychologist G. M. Andreyeva points that the "problem of 'insertion' in the historical time stands especially sharp in situations of radical social transformations... and an important stage in this process is represented by the understanding of time" [2, ANDREEVA, G.M., 2009].

The research of the problem of the attitude to time is studied on societal, group. Interpersonal, and intrapersonal levels [9. Nestik, T., 2014; 16, SYRCOVA A., MITINA O.V., et al., 2007; 14, EMEL'ÂNOVA, T.P., 2006; 15, KUZNECOVA, A.V., 2013].

We find very interesting for our research, the results of empirical studies regarding the manifestation of the phenomenon of time perspective in different cultures, conducted by researchers (Apostolidis T., Fieulaine N., 2004; Boyd J.N., Zimbardo P.G., 1999, 2005; Keough K.A., Zimbardo P.G., Boyd J.N., 1999; Syrtsova A., Mitina O.V., Boyd J., Davydova I.S., Zimbardo F., Nepryaho T.L., Nikitina E.A., Semenova, 2007) from different countries (France, USA, Russia).

Time perspective is defined by the give researchers as "a fundamental and unconscious process, by which social and individual experience is correlated with time categories, which allows to give meaning and coherence to the lived experience" [16, SYRCOVA, A., MITINA, O.V. i dr., 2007].

The research of time perspective in Italy (D Alessio M., Guarino A., Vilfredo De Pascalis V., Zimbardo Ph., 2003) revealed a significant correlation between time perspective and level of education. The researchers presupposed that the low educational level having a direct proportional relation with low socio-psychological statute, when nothing depends on a person's desires, could lead to the formation of a passive submission to events. [16, SYRCOVA, A., MITINA, O.V. i dr., 2007].

The research of time perspective in France (Apostolidis T., Fieulaine N., 2004) reveals that adverse situations are associated with a lesser orientation toward the future, and with a greater orientation toward the present and past. Focusing on a negative past is accompanied by a significant decrease in psychological well-being. These results confirm the relationship of the time perspective with the social conditions of existence and its role in subjective well-being. [16, SYRCOVA, A., MITINA, O.V. i dr., 2007].

A study of the time perspective in Russia (Syrtsova A., Mitina O.V., Boyd J., Davydova I.S., Zimbardo F., Nepryaho T.L., Nikitina E.A., Semenova, 2007). It was found that younger respondents are characterized by the manifestation of the "Hedonistic Present" factor, and at an older age - the important factor that is taken into consideration represent the Future factor.

Excessive concentration at one form of time is determined by such factors as culture, education, religion, membership in a social class. The preference for a specific time orientation is largely determined by the country of residence (national identification). In some societies (western), the value of autonomy and the future is encouraged, while in other cultures, on the contrary, orientation toward the past is supported [16, SYRCOVA, A., MITINA, O.V. i dr., 2007].

\section{SOURCES OF DATA AND USED METHODS}

The goal of our research is the investigation of the perception of time, values system by different age and ethnic groups in a transitional society.

One of the hypotheses of our research was the supposition that socio-economic changes occurring in the society will influence the values system, time perspective and the perception of present time by large social groups - age and ethnic groups.

In our research we made as well the hypothesis according to which the perception of time, values system by different social groups (age, ethnic) gives the possibility to understand from different perspectives the groups' state in a transitional society.

One can orient himself/herself in the new complex world, or understand it, only if he/she can in an appropriate way to interpret the ongoing processes, facts, otherwise he/she can "easily lose the meaning of both what is happening and his/her place in it".

Today, we consider an important task to understand and reveal the mechanisms "through which human being sees himself/herself as part of that reality in which he/she lives and acts, as well as all the factors that determine these processes" [2, ANDREEVA, G.M, 2009.].

THE METHODOLOGICAL BASIS of our investigation represents the systemic approach and social 
constructivism. Our basic hypotheses in the give research are the following:

1) The awareness of the world represents the result of mutual activity of people; "their relations, words used to define / describe social processes are meaningful and significant only in the context of these relations";

2) The widespread presence of certain form of understanding depends on the character of social processes, and the rule "how to define or name things", is determined by the character of social changes [17, ANDREEVA, G.M., 2009].

In the given article we are going to present a part of our empirical research - the perception of time by youngers; by ethnic groups (Kaunenco I.); and peculiarities of values system in groups of early aged adolescents (Gasper L.).

The scientific novelty of our research represents the determination of peculiarities of values system, the perception of present time by large social groups (age and ethnic) in transitional society, namely: planning time perspective, variability in the attitude to present time, hierarchy of values system as bases for the formation of collective subjectivity.

THE CHARACTERISTICS OF SAMPLE AND METHODOLOGY OF THE EMPIRICAL STUDY

Regions of research - Chisinău municipality, ATU Gagauzia (Autonomous Territorial Unit of Gagauzia) - Comrat, Chirsova village; Tvardita city; Rișcani district, Malinovscoe village; Cahul district, Lucești village; Singerei city. (Period of research - May-September 2016). Leova district, Cazangic village; Telenesti district, Negureni village. (Period of research - April 2019) (57 respondents aged 15-17); focus-groups organized in: Bălți municipality (14 respondents) and Comrat city (17 respondents).

Table 1

Sample structure

\begin{tabular}{|l|c|c|}
\hline Ethnic group & Nr. of respondents & Age (average) \\
\hline Russians & 40 & $\mathrm{~A}=39$ \\
\hline Bulgarians & 36 & $\mathrm{~A}=39$ \\
\hline Gagauz people & 40 & $\mathrm{~A}=41$ \\
\hline Ukrainians & 36 & $\mathrm{~A}=41$ \\
\hline Total & 152 & \\
\hline
\end{tabular}

Source: Elaborated by the author.

\section{Characteristics of sample in focus groups (2018)}

The sample in Bălți city was composed by young people aged 20-40 (14 respondents), from this reason the questions regarding the time perspective, the experience of present time in the period of society transformation had a vivid and consistent character. The educational statute: young people had completed higher education, or were studying at university (Cycle 1), or master cycle (Cycle 2). The focus group of Comrat city (17 respondents), from the age point of view was mixed, that is why in the given article we analyze the results of researching young people only.

Methodology: 1) Method "Scale of time attitudes" [10, NÛTTEN, Ž., 2004]. 2) In order to research the time perspectives we used the question: "For what period you can plan your life?" and there were some options of answer that characterize different length of the planning period. The given question was borrowed from the research of N. M. Lebedeva and A. N. Tatarco [8, LEBEDEVA, N.M., TATARKO, A.N., 2007] related to the time perspective. 3) Semi-structured interview regarding the perception of time (focus groups). 4) In order to study the values system of respondents represented by adolescents of early age we used the method of E. B. Fantalova (1992) [7, KRIVCOVA, S.V., 1997].

THE RESULTS OF THE EMPIRICAL RESEARCH AND THEIR ANALYSIS. The empirical research of time perspective of the groups of - Russians, Bulgarians, Gagauz people, Ukrainians reveals that the respondents of the given groups actually use to plan their future for a very short period of time from 1 to 5 years. Thus a significant number of respondents can plan their future for 1-5 years: $50 \%$ of Russians, $40 \%$ of Gagauz people, 38,9\% of Bulgarians, $44,4 \%$ of Ukrainians. But there is a big part of people that cannot plan at all $-37,5 \%$ of Russians, $41,7 \%$ of Ukrainians, $41,7 \%$ of Bulgarians, $40 \%$ of 
Gagauz people. The rest of answers were chosen by insignificant number of respondents. Thus, in present time, the representatives of researched ethnic groups don't develop a long time perspective. In every ethnic group half of respondents or a little less of half (Gagauz people, Bulgarians, Ukrainians) can plan their life from 1 to 5 years.

In our research we studied as well the perception of present time by the respondents of ethnic groups.

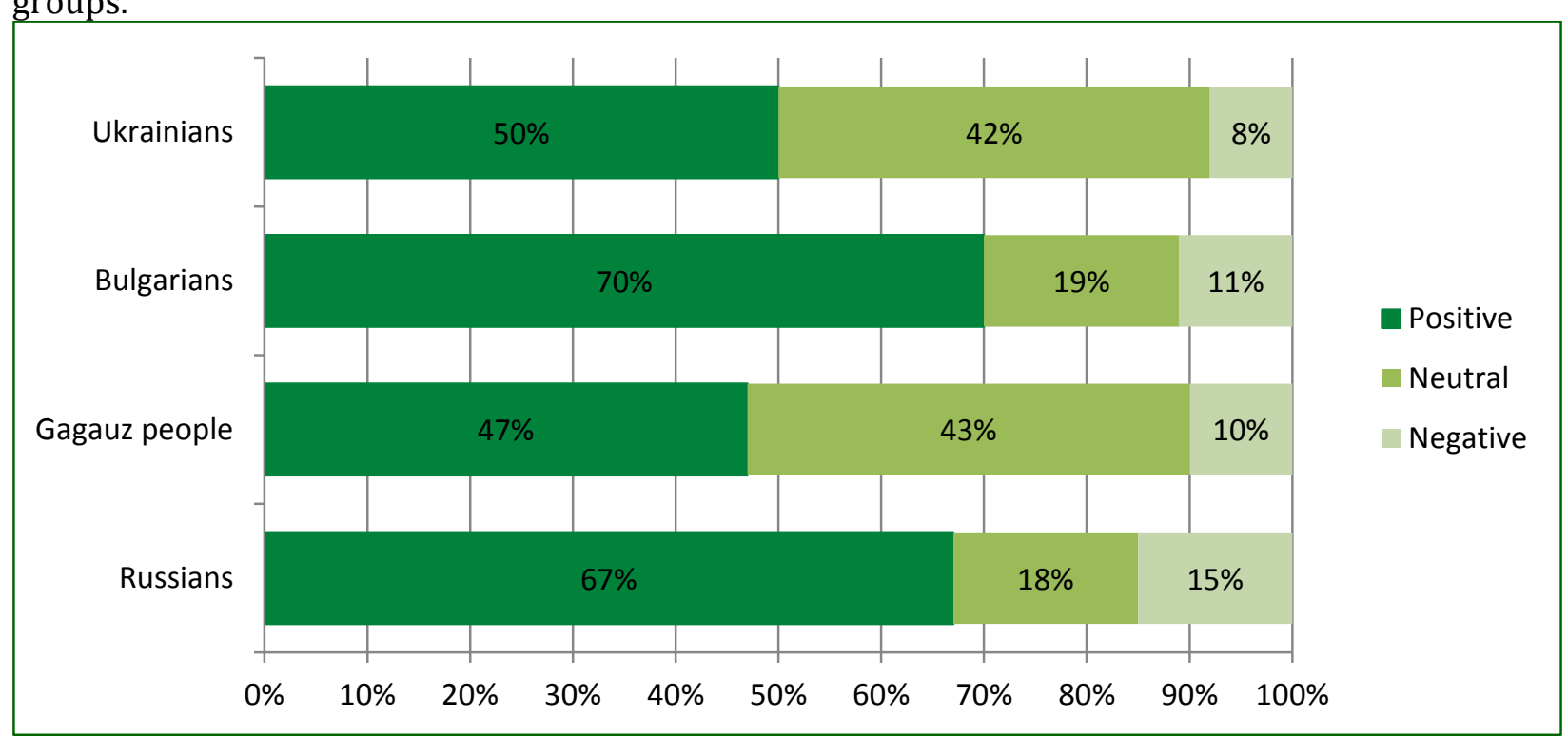

Figure 1. The perception of present time by respondents

Source: Author's calculations.

According to the results presented in diagram, regarding the perception of present time in Gagauz people (fig. 1), the positive attitudes are lesser emphasized (47\%). Gagauz people (43\%) and Ukrainians (42\%) are characterized by neutral attitude towards time.

As well, we can see that in the groups of Russians (67\%) and Bulgarians (70\%) positive perception of present time dominates, and the results regarding the neutral perception of time is lower (Russians 18\%; Bulgarians 19\%).

Thus, we can conclude that the present time is perceived more positively by the groups of Russians and Bulgarians, less positive perception is dominating in the group of Gagauz people. The groups of Ukrainians and Gagauz people are more characterized by neutral attitudes regarding the perception of present time.

THE RESULTS OF ANALYSIS OF THE PROFILES OF ATTITUDES TO PRESENT TIME IN RESEARCHED ETHNIC GROUPS, QUALITATIVE ANALYSIS

The group of Gagauz people perceives the present time as important, swift, full of hope, wonderful, familiar. Among negative features of the present time perception, the respondents from this group mentioned often - difficult, threatening. Such characteristics of present time in Gagauz people as short, externally determined, passive waiting, closed, enjoyable are more "dispersed". Concerning these characteristics of present time perception, the respondents are more uncertain. Thus, the perception of present time by the group of Gagauz people is characterized as swift, full of hope, wonderful, at the same time threatening and difficult.

The group of Russians perceives the present time as full, interesting, swift, open, familiar, everchanging, important, successful (completed). Among negative characteristics there are - difficult, short. Russians are uncertain regarding the following features: attractive - threatening, my personal - determined externally, warm - cold, distant - close, pleasant - unpleasant. Thus, the group of Russians perceives the time as full, interesting, swift, open, familiar, ever-changing, important, successful (completed), and at the same the time is - difficult and short.

The group of Bulgarians perceives the present time as ever-changing, pleasant, full, important, 
my personal, wonderful, swift, full of hope, interesting. Concerning the negative characteristics of present time, they mentioned - difficult. The group of Bulgarians is uncertain regarding the following features of present time: easy - difficult, warm - cold, completed - disappointing, long -short, attractive - threatening.

The group of Ukrainians perceives the present time as open, important, full, swift, wonderful, ever-changing, full of hope. Negative characteristics - difficult, cold. Regarding the following features there is no consensus: warm - cold, full - empty, attractive - threatening, long -short, completed disappointing, i.e. successful - unsuccessful, personal - determined externally. As we can see, the group of Ukrainians, generally, perceives time positively, but it is also dividing concerning success and failure in time, personal - determined externally, i.e. depending on locus of control. Thus, all these ethnic groups perceive time as ever-changing, open, swift, important, at the same time difficult and threatening. For a better understanding of time perception at the group level by different social groups, not only the quantitative tools are important but also the qualitative methods, such as working in focus groups.

THE RESULTS OF RESEARCHING THE PERCEPTION OF TIME BY YOUNG PEOPLE IN FOCUS GROUPS. In the given article we combined the empirical material gathered from focus-groups realized in Bălți municipality and Comrat city (ATU Gagauzia). We divided conditionally the following groups of youngers according the perception of present time.

1. "Optimists"

The main message of this group is the following: "The time is 'mine', and it is interesting to live in it". They are confident in their good future, they can keep up with times, they can develop themselves both professionally and personally ("I feel comfortable"). They have professional accomplishments (they are successful regarding the professional accomplishments), often due to the involvement in international cooperation. Although with reservations, they characterize time as difficult and complicated for people around them, especially for the older generation. They disagree with the assessment of the parents regarding the definition of the present: "Parents always share with us, then it was like that, maybe..., they think that it was better then. We don't think so. I feel comfortable, maybe not $100 \%$. I would not say that all areas are ideal as I would like", "I believe that my time, despite the decline in the country, can still grow." Time is perceived by respondents of this group as dynamic, technological, motivates them for the future: "...I feel the changes, everything is moving so fast, it is developing so fast, I like it. I can also change in parallel with time. Society is developing dynamically, such information leaps happen, which is difficult follow. But I like it, I feel that this era is mine, and I have a good future." A quick change of events does not scare them, does not give rise to a sense of anxiety, but rather, creates a comfortable state.

Our respondents, according to their age, in their majority, refer to the generation "millennium", and it is characterized by such values as - "freedom", "creation", "entertainment"; every "millennium" begins feel unique and unrepeatable. Max Prenski defines the "millennium" generation through its interaction with informational technologies - "digital aboriginals" [4]. "News", "lot of events" motivate such generation, "lure" them and create the "comfort zone" as in the perception of present time, as well as of the future.

2. «Positive fatalists»

The positive-fatalistic attitude to the present is "as it will be, it will be so". The respondents of this group worry that they don't have time to realize everything, and someone "as far as possible": "the time is mine, when I have time, when I don't have time. As far as possible. They are anxious in terms of money, finances, when they are enough / not enough. Normal time, I don't know another." For the respondents of this group, professional realization plays a big role, and the marker of the present is the opportunity to get an education abroad, to participate in international projects.

3. «Socially-anxious»

These respondents perceive present time as "fragile", "unstable", "volatile", there is no certainty about "anything". An important factor in the perception of the present time by respondents represents the socio-economic situation in the country: "As for planning, I can say that it all depends on our stability in this country. How can one plan something for the future without knowing what will happen to this country. For a long period you cannot plan, because there is no certainty about 
anything. Even with regard to the financial side, you cannot take out a loan, because there is no stability in work, and there are no other sources of subsistence. ... I can plan for several days in advance, I can also plan the implementation of family issues. You cannot even plan a trip because you do not know whether you will have time for this or not ... We are at an age when everything changes. We want more. Many want to live today, the present, for the future you need to be optimistic". The respondents in this group revealed difficulties in controlling time, its successful management, and the inability to organize a sequence of events. The prospect of the future is difficult, and it is possible to predict difficulties with time integration, at least at this time stage.

It seems that this type of perception of time today will be characteristic of a significant part of youth. And we can speculate that this inability to manage time due to institutional instability will be one of the "pushing" factors for inclusion in labor migration or emigration. The participants of the focus-groups mentioned these options as possible.

In the process of researching the perception of time by different ethnic and age groups, an idea was born - to carry out a pilot comparative study on labor migrants that are working in Italy [18, $\mathrm{p}$. 53-56].

We wanted to get answers for the following question: How the labor migrants perceive the socio-cultural changes in our country? We conducted a survey of 17 respondents - Moldovans that are working in Piacenza city, in the southeast of Italy. The survey, on our request, was conducted by Tat'yana Roshka, a PhD student at ULIM, in august 2018. The age of the selected sample was between 40-60 years. The given research has a pilot character. The survey had three questions: "When you are back in Moldova, what changes are mostly obvious, from your point of view?", "Do you want your children to remember the Republic of Moldova?", "What they should remember?".

We will describe shortly the results of this empirical study.

1. According to the perception of labor migrants, the socio-cultural changes in the country are noticed in material sphere and in the interpersonal relationships. The dispersion of perceptions is characterized by polarization, from extremely positive to negative, with the dominance of the positive.

2. In the content of ethno-cultural transmission by parents to their children, a positive attitude to homeland, country dominates. The majority of parents want children to remember and to preserve national traditions which will be, as we suppose, an important marker in preserving the ethnic identity in young "Italian Moldovans". Along with this, the labor migrants have also negative experiences of the country (embarrassment regarding the material/financial difficulties both in homeland and Italy, in the beginning of their emigrant history).

For psychologists, the value sphere presents a specific interest being an extremely generalized social experience obtained by a person in ontogenesis, as elements of a single semantic field [11, POČEBUT, L.G., 2003]. Values are a powerful sense-forming, motivating construct forming the "picture of the world" in adolescence and youth. Further, as researches show, the value system remains fairly stable, despite even the socio-economic systemic changes in young, mature ages [19, GAVRELIUC, D., GAVRELIUC, A., 2018].

To understand the genesis of personal development in adolescence, during the period of transitivity, we conducted a study of their value system. We briefly dwell on the results of the empirical study. We insist to mention an interesting fact got in the research - the difference between the 'Value' and 'Accessibility' indicators, which reflects the level of mismatch, disintegration in the value-motivational sphere of the individual. It characterizes its internal conflict as a "blockade" of leading needs on the one hand, and self-realization, personal identity on the other. We have identified a conflict in the values of 'Health' and 'Happy family life', as very significant, but difficult to access. We suppose that many of our respondents, residents of rural areas, have parents included in labor migration. And perhaps the family, its social practices represent an unsatisfied need - in emotionally close relationships with relatives, which are often episodic, "virtual" in nature (during the period when the parents come from abroad or communicate on the Internet). The value of 'Health', this is perhaps a reflection of communication with loved ones, regarding the labor market - where health and physical endurance are important. Based on the average indicators (attractiveness, value) of various life spheres, we compiled a rating of adolescents' values. 


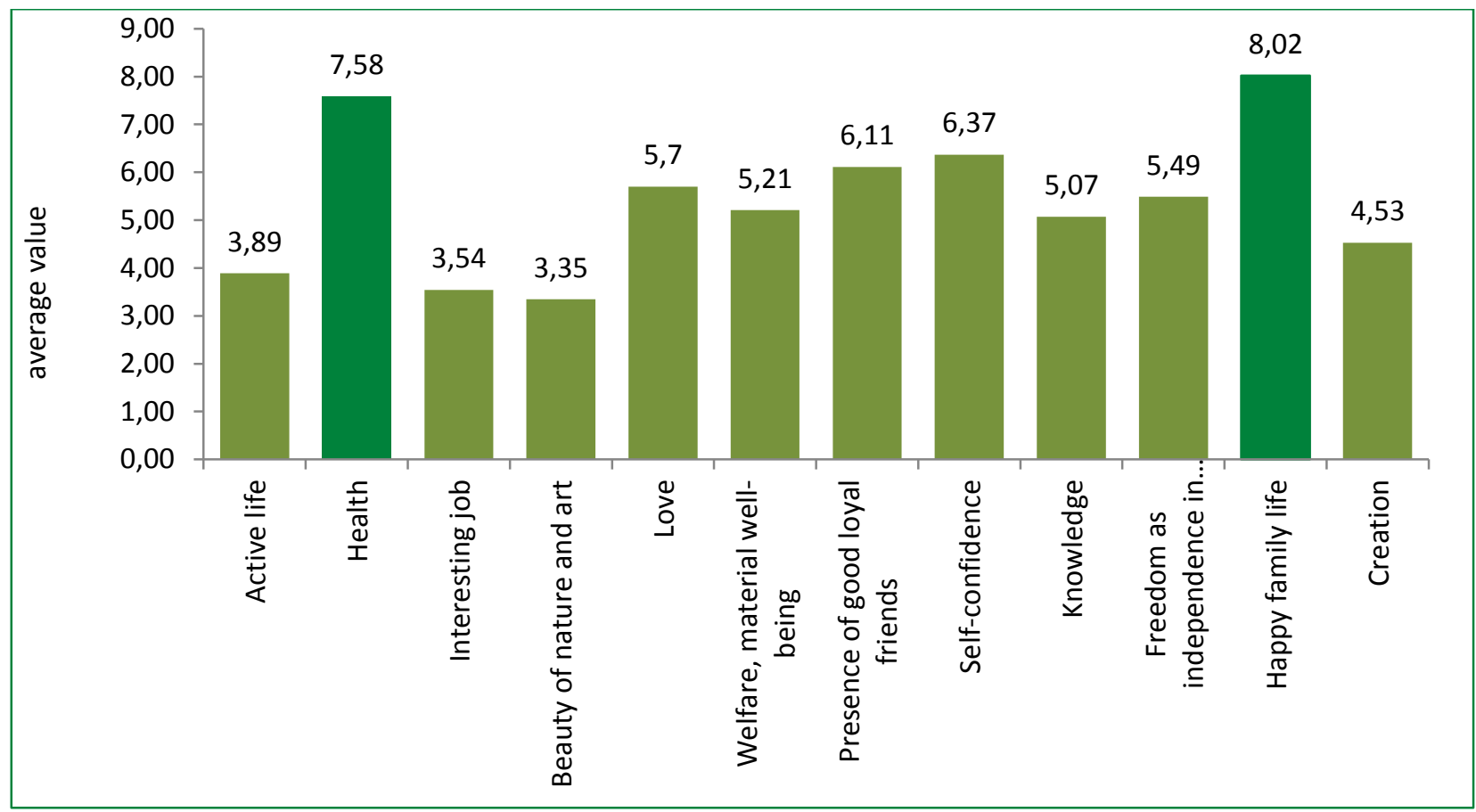

Source: Author`s calculations.

Figure 2. Values rating

As we can see, from the presented results of the given empirical study, the spheres "Happy family life" and "Health" have the highest values. The respondents value the least such spheres as "Beauty of nature and art", "Interesting job". Apparently, this is determined by the pragmatism of modern public life, in which first of all things that are worthwhile and worthy are valued, and "interesting work", which would be well paid, is a rare guest in our regional space in the views of our young respondents.

It's interesting the fact, that researcher Kaunenco I. I. in her study on values system of Moldavian young students in 2019, by means of S. Schwartz method, has determined that such values as "family protection", "health" were the most preferred, significant values, having the smallest spread of data. The least preferred values were "creativity", "the world of beauty", "spiritual life", presenting a big discrepancy of attitudes among the respondents' hierarchization. Such a hierarchy of values is characteristic for countries in a situation of survival, rather than self-realization (such as countries of the European space). The conducted factor analysis of the value sphere of student youth has revealed both an orientation towards both traditional and innovative values, and one of the factors was called "Cultural Crossroads". Where does the value-time pendulum swing in different social groups, this is a study field for further research.

It seems to us that at present, studying the perception of time and the value system of different social groups will help to understand and predict the vector of the future socio-cultural development of our region.

\section{CONCLUSIONS}

1. The research of the time perspective of the representatives of ethnic groups revealed that they actually plan their future for a very short period of time from 1 to 5 years. Concerning the perception of present time, in the groups of Russians, Bulgarians a positive perception dominates, in the group of Ukrainians - the group perception is divided in two, and the less positive perception is peculiar for the group of Gagauz people. In the groups of Gagauz people and Ukrainians neutral attitudes are more emphasized regarding the perception of present time. In all ethnical groups the present time is perceived as ever-changing, open, swift, important, and at the same time, difficult and threatening.

2. The groups of youngers that we divided conditionally according to the time perception, from 


\begin{abstract}
"optimists" to "socially-anxious", indicate the patchiness of our society, that include resourceful generational and reform potential (youngers - "optimists") as well as the group, that in the conditions of continuous decline of the social-economic development of the region, has the tendency to migrate, because "nothing can be planned in the future".

3. The research of values system of the respondents adolescents, revealed the unsatisfied need in the emotional-personal familial relations, in positive family practices, and anxiety regarding the value "Health" as resource of the potential of labor migration.

The research of time perception and values system in different social groups is promising taking into consideration the society need for normal functioning of social institutions. The success of their functioning depends on the values system of citizens and strong belief in the prospect of common positive future.

It seems promising to research the options for responding groups - age, ethnic to systemic socio-economic changes in society. It is also necessary to study the national mentality of our region, since social institutions can function successfully only with the "support" of the mentality.
\end{abstract}

\title{
REFERENCES
}

1. ANDERSON, Benedikt. Voobražaemye soobŝestva. Razmyšlenia ob istokah i rasprostranenii nacionalizma. Moskva: Kučkovo pole, 2016. 416 s. ISBN 5-93354-017-3.

2. ANDREEVA, G.M. K voprosu o progresse v social'noj psihologii. V: G.M. ANDREEVA. Social'naâ psihologiâ segodnâ: poiski i razmyšleniâ. Otv.red. O.V.KRASNOVA.Moskva: NOU VPO MPSI, 2009, ss. 7-36. ISBN 978-5-9770-0446-6.

3. Social'noe vospriâtie - ishodnyi punkt. V: G.M. ANDREEVA. Psihologiâ social'nogo poznaniâ. Moskva: Aspekt Press, 2000, ss. 43-51. ISBN 5-7567-0248-2.

4. BEZBOGOVA, M.S., IONCEVA, M.V. Social'no-psihologičeskij portret sovremennoj molodeži. V: Mir nauki. 2016, tom 4, nomer 6. ISSN 2309-4265. [Accesat 23.09.2019]. Disponibil: https://mirnauki.com/PDF/35PSMN616.pdf

5. BOGOMOLOVA, N.N., DONCOV, A.I., FOLOMEEVA, T.V. Psihologiâ bol'ših social'nyh grupp: novye sud'by, novye podhody. V: T.L. ALAVIDZE, G.M. ANDREEVA i dr. Sovremennaâ psihologiâ v sovremennom. Moskva: Aspekt Press, 2002, ss. 132-148.

6. DILEGENSKIJ, G.G. Social'no-političeskaâ psihologiâ. Moskva, 1994. 304 s. ISBN 5-02-013558.

7. KRIVCOVA, S.V. Podrostok na perekrestke èpoh. Moskva: Genezis, 1997. 280 s. ISBN 5-85297004-2.

8. LEBEDEVA, N.M., TATARKO, A.N. Cennosti kul'tury i razvitie obŝestva. Moskva, 2007. 499 s. ISBN 978-5-7598-0498-7.

9. NESTIK, T.A. Social'naâ psihologiâ vremeni. Moskva: Iz-vo Institut Psihologii RAN, 2014. 496 s. ISBN 978-5-9270-0282-5.

10. NÛTTEN, Ž. Motivaciâ, dejstvie i perspektiva budushŝego. Pod red. D.A. LEONT'EVA. Moskva: Smysl, 2004. 608 s. ISBN 5-89357-151-7.

11. POČEBUT, L.G. Psihologiâ social'nyh obŝnostej (tolpa, socium, ètnos): avtoreferat dissertacii na soiscanie učenoj stepeni doktora psihologičeskih nauk. SPb, 2003. $46 \mathrm{~s}$.

12. KAUNENKO, I.I. Vospriâtie vremeni ètničeskim gruppami Respubliki Moldova: social'nopsihologičeskij aspekt. In: Ştiinţă, educaţie, cultură: conferinţă ştiinţifico-practică internaţională. Komrat: Tipografia "A\&V Poligraf, 2019, vol. 1, pp. 487-491. ISBN 978-9975-3246-4-9.

13. MARCINKOVSKAÂ, T.D. Istoriâ, kul'tura, razvitie kak obrazuûŝie istoriko-genetičeskoj paradigmy. V: Kul'turno istoričeskaâ psihologiâ. 2015, tom 11. № 4, ss. 69-78. ISSN 1816-5435.

14. EMEL'ÂNOVA, T.P. Konstruirovanie social'nyh predstavlenij v usloviâh transformacii rossijskogo obŝestva. Moskva: Izd-vo «Institut psihologii RAN», 2006. $400 \mathrm{~s}$.

15. KUZNECOVA, A.V. Kollektivnaâ pamât' o značimyh sobytiâh i figurah rossijskoj istorii v različnyh social'nyh gruppah: dissertaciâ na soiskanie naučnoj stepeni kandidata psihologičeskih nauk. Moskva, 2013. $166 \mathrm{~s}$.

16. SYRCOVA, A., MITINA, O.V. i dr. Fenomen vremennoj perspektivy v raznyh kul'turah (po materialam issledovanij s pomoŝ'û metodiki ZTPI). V: Kul'turno-istoričeskaâ psihologiâ. 2007, tom 3, № 4, ss. 19-31. ISSN 1816-5435. 
17. ANDREEVA, G.M. Social'naâ psihologiâ: vektory novoj paradigmy. V: Psihologičeskie issledovaniâ. 2009, № 1 (3). ISSN 2075-7999. [Accesat 15.10.2019]. Disponibil: http://psystudy.ru/index.php/num/2009n1-3/55-andreeva3.html

18. KAUNENKO, I.I. Vospriâtie sociokul'turnyh izmenenij v Respublike Moldova trudovymi migrantami moldavanami. V: Moldova i Gagauziâ v kontekste razvitiâ moldavskoj gosudarstvennosti: Naučnopraktičeskaâ konferenciâ s učastiem učonyh Respubliki Moldova posvâŝennaâ 660-letiû moldavskoj gosudarstvennosti, 17 sentâbrâ 2019. Komrat, 2019, ss. 53-56.

19. GAVRELIUC, D., GAVRELIUC, A. Generational Belonging and Historical Ruptures: Continuity or Discontinuity of Values and Attitudes in Post-Communist Romania. In: N. LEBEDEVA, R. DIMITROVA, J. BERRY (eds.). Changing values and identities in the post-communist world. Societies and political orders in transition. Springer, 2018. pp. 207-222. [Accesat 23.09.2019]. Disponibil: https://www.springer.com/gp/book/9783319726151

\section{ARTICLE HISTORY}

Received 01 October 2019

Accepted 15 November 2019 


\title{
ACQUISITION OF FOREIGN CITIZENSHIP BY MOLDOVAN IMMIGRANTS
}

\author{
Tatiana TABAC ${ }^{1}$, PhD Student, \\ National Institute for Economic Research, Republic of Moldova
}

\author{
DOI: https://doi.org/10.36004/nier.es.2019.2-09 \\ JEL Classification: F22, K37, J11 \\ UDC: $314.74,325.14$
}

\section{ABSTRACT}

The paper explores some aspects of the acquisition of foreign citizenship by immigrants from Moldova. The purpose of the study is to estimate the size and geography of acquisition of foreign citizenship in context of migration policies changes in countries of destination. The study is based on statistical analysis of the OECD, Eurostat database and other representative sources, as well as an analysis of migration policy of the countries of citizenship acquisition. The results show that about a million people received foreign citizenship from 1992 up to present. The main countries for acquiring citizenship are: Romania, Russia, USA, Portugal, Italy, Bulgaria, Canada and Germany. The access of Moldova population to citizenship of developed countries contributes to the intensification and expansion of international migration. For Moldovan immigrants, the policies of the countries of destination have an important role in the process of acquiring citizenship.

Keywords: naturalization, foreign citizenship, Moldovan immigrants, migration policy.

In articol se discută unele aspecte privind dobândirea cetățeniei străine de către imigranții din Moldova. Scopul cercetării constă în estimarea dimensiunii și geografiei dobândirii cetăteniei străine prin prisma schimbărilor în politicile migraționale din țările de destinație. Studiul se bazează pe analiza statistică a bazei de date OCDE, Eurostat și a altor surse reprezentative, precum și analiza politicilor migraționale ale țărilor de dobândire a cetățeniei. Rezultatele studiului arată că aproximativ un milion de persoane au primit cetățenia străină din 1992 până în prezent. Principalele țări de dobândire a cetățeniei sunt: România, Rusia, SUA, Portugalia, Italia, Bulgaria, Canada și Germania. Accesul populației Moldovei la cetățenia țărilor dezvoltate contribuie la intensificarea și extinderea migrației internaționale. Pentru imigranții din Moldova, politicile țărilor de destinație au un rol important în procesul de dobândire a cetățeniei.

Cuvinte-cheie: naturalizare, cetățenie străină, imigranți din Moldova, politici migraționale.

В статье рассматриваются некоторые аспекты приобретения иностранного гражданства иммигрантами из Молдовы. Цель исследования: оценка масштабов и географии приобретения иностранного гражданство в контексте изменений миграционной политики в странах назначения. Исследование основано на статистическом анализе базы данных ОЭСР, Евростата и других репрезентативных источников, а также анализе миграционной политики стран приобретения гражданства. Результаты исследования показывают, что около миллиона человек получили иностранное гражданство с 1992 г. по настоящее время. Главными странами приобретения гражданства являются: Румыния, Россия, США, Португалия, Италия, Болгария, Канада и Германия. Доступ населения Молдовы к гражданству развитых стран способствует интенсификации и расширению международной миграции. Для иммигрантов из Молдовы политика стран назначения играет важную роль в процессе получения гражданство.

Ключевые слова: натурализация, иностранное гражданство, мигранты из Молдовы, миграционная политика.

INTRODUCTION. There are already three decades since international migration became a massive phenomenon for the Republic of Moldova. The last censuses in the destination countries (2011) registered about 600 thousand migrants from Moldova with residence abroad (15, GAGAUZ, 
O., et al. 2016), this number representing about $20 \%$ of the total population. According to recent estimates, Moldova is one of the countries with highest emigration rates in the European area (13, European Demographic Data Sheet, 2018). In some countries, duration of stay of immigrants exceeds 10-20 years (e.g. Germany, Russia, Italy, Portugal, USA), meaning that for many immigrants the host country has become the country of permanent residence. In Russia, Germany (28, TABAC, T., 2017) and Italy (9, DELEU, E., 2017) second-generation immigrants were registered already. The analysis of citizenship and its acquisition by Moldovan immigrants is necessary, on the one hand as part of studying their integration in destination countries, and on the other hand as an important factor contributing to the expansion of international migration. For Moldovan immigrants, acquiring the citizenship of one of the EU countries represents firstly free movement and the right to work in almost all countries worldwide, and secondly a wider range of opportunities for settlement migration for people who aspire to do so. In this context, in recent decades, access to Romanian citizenship is an important factor that favors legal migration. The purpose of the research is to estimate the size and geography of acquisition of foreign citizenship during the 1992-2016 period, according to the countries which conferred them and naturalization policies that favored this. To our best knowledge, there aren't any studies that approach the naturalization process and acquisition of foreign citizenship by Moldova population. Therefore, the importance of our study is determined by supplementing this gap, as well as by contributing to the development of migration policies.

\section{UNDERSTANDING NATURALIZATION DECISIONS}

There are numerous research papers that study the determinants, causes, barriers and consequences of the immigrants naturalisation in destination countries. All of these studies are conducted to understand why some immigrants are more likely than others to become naturalized. Regardless of the country and promoted policies, most research shows that only a fraction of the eligible immigrants access the citizenship of the host country (22, Mazzolari, 2009; DeVoretz and Pivnenko, 2005).

In literature we find various factors that determine an immigrant to access the citizenship of the country in which he/she lives. Some studies emphasize the importance of the individual characteristics of immigrants such as demographic characteristics (4, BEVELANDER, P., VEENMAN, J. 2006), economic characteristics- income, occupation and education (7, CHISWICK, B.R., MILLER, P.W., 2008; 12, DEVORETZ, D.J., PIVNENKO, S., 2005), period of immigration or residence (30, TRAN, K., KUSTEC, S., CHUI, T., 2005), cultural background. In other studies, the focus is on the political and institutional context of country of immigration as a factor that also influences the naturalization process (32, VINK, M.P., PROKIC-BREUER, T., DRONKERS, J., 2013; 33, VINK, M.P., DRONKERS, J., 2012). In addition, some studies show that the characteristics of the origin country influence the naturalization process in destination countries, particularly regarding the possibility to hold dual citizenship (34, YANG, P.Q., 1994; 7, CHISWICK, B.R., MILLER, P.W., 2008, 19, JONES-CORREA, M., 2001), although not as much as individual characteristics. In this aspect it has been demonstrated that immigrants from developing countries have higher naturalization rates, than immigrants from developed countries (7, CHISWICK, B.R., MILLER, P.W., 2008; 31, VINK, M.P., PROKIC-BREUER, T., DRONKERS, J., 2017).

An important barrier in the naturalization process is the possibility to hold double citizenship, granting the right of migrants to become naturalized in the receiving country without losing the nationality of the country of origin. Though, many countries have already legalized dual citizenship, there are countries in the world that do not accept it, as well as countries that impose restrictions on acquisition, many of which are located in Europe. Prohibition on dual citizenship affects especially immigrants from developed countries, who have more to lose if they break the legal connection with the country of birth (32, VINK, M.P., PROKIC-BREUER, T., DRONKERS, J., 2013). In this sense, the researchers consider that losing the citizenship of country of origin is the main cost of naturalization (2, BEVELANDER, P., 2010).

At the same time, the existence of other important barriers in the naturalization process was demonstrated, as a good knowledge of the language, the difficulty of the citizenship test, the physical presence in the country, but also the financial barriers, as well as the high cost of documents 
processing. For example, Hainmueller et al. $(18,2018)$ have shown that administrative taxes are a barrier for low income immigrants who want to become US citizens.

However, acquiring the citizenship of destination country offers more benefits to immigrants, but first represents the people's intention to permanently settle in the country. Most often it is considered that the benefits of naturalization are the equal rights with citizens of destination country, the right to vote and political participation (10, DEROOIJ, E.A., 2011), greater insurance and protection from the state, the chance of being employed in public and governmental positions, the opportunity to increase the income and to obtain higher professional positions (Liebig and Von Haaren 2011), to buy or to rent a house (2, BEVELANDER, P., 2010), as well as more access to bank loans (14, ENCHAUTEQUI, M.E., GIANNARELLI, L., 2015). For citizens of developing countries, the citizenship of a developed country is a benefit to travel without barriers at international level (14, ENCHAUTEQUI, M.E., GIANNARELLI, L., 2015; 33, VINK, M.P., DRONKERS, J., 2012). At the same time, refugees, asylum seekers and persecuted people in their country of origin will be more motivated to become naturalized in the host country (3, BEVELANDER, P., DEVORETZ, D.J., 2008).

From all the benefits obtained from naturalization the most attention is on the economic impact of naturalization. Lots of studies both at European, and global level shows how important is the economic effect for naturalized immigrants. We find a positive relationship in this regard to Bratsberg, Ragan Jr., and Nasir (6, 2002), DeVoretz and Pivnenko (12, 2005), Steinhardt and Wedemeier $(26,2011)$, Picot and Hou $(23,2011)$. It has been found for the US that naturalization can increase the earnings of eligible immigrants with 8,9\% (14, ENCHAUTEQUI, M.E., GIANNARELLI, L. 2015), and according to the estimates of DeVoretz and Pivnenko $(11,2008)$, naturalized immigrants have the incomes with 3.5\% higher than non-citizens if they are from an OECD country and with $14.6 \%$ if they are from outside OECD.

Acquizition the citizenship of country of immigration represents a process that requires applicants to demonstrate language and historical-cultural knowledge, financial independence, adequate civic behaviour, or in other words, to show evidence of social integration. For this reason obtaining citizenship is considered the coronation of a completed integration process $(1$, BAUBOCK, R. et al., 2006).

\section{DATA AND METHODS}

For analysis, we used the data on the acquisition of nationality provided by OECD and Eurostat. For Russia, we used the data provided by Minister of the Interior/ Federal Migration Service and presented by Čûdinovskih, O.S. $(8,2018)$. To study worldwide policies, we used World Population Policies Database by UN DESA, and EUDO Citizenship Observatory database for national level policies. The study is based on statistical data analysis and policies analysis.

World experience in acquiring foreign citizenship

There are two main ways of acquiring citizenship at birth: jus sanguinis, it offers nationality right only to persons with the same racial, linguistic, ethnic and cultural characteristics of titular nation and jus soli, which establishes citizenship right whether or not the person corresponds to the mentioned characteristics. J.B. Scott records in 1930 that in 17 countries in Europe, jus sanguinis is the only nationality test, while in America most states use a combination of these two paths. In the long run, many European countries adopted jus soli criterion (recently Germany and Greece) and today we know a more frequent coexistence of these two criteria (17, GUIMEZANES, N., 2011).

Naturalization is another way of acquiring citizenship and it is used by people who don't have jus sanguinis or jus soli connection with the country. Naturalization is the process by which a foreign citizen can acquire, under the law conditions, the citizenship of country of resident. At present, naturalization is recognized and used worldwide, except some countries from Asia and Oceania (Lebanon, Kuwait, United Arab Emirates, Myanmar, Nauru) (Fig.2). At the same time, a large number of countries restrict acquisition of citizenship through naturalization. These are European countries such as Spain, Italy, Switzerland, Austria, Slovenia, Lithuania and the Republic of Moldova (Fig. 1), India and Nepal from Asia, Brazil and Venezuela from South America, as well as an important part of African countries. Typically, naturalization is a voluntary action of applicant and requires that certain specific conditions to be met. Each country has adopted own requirements for naturalization. 


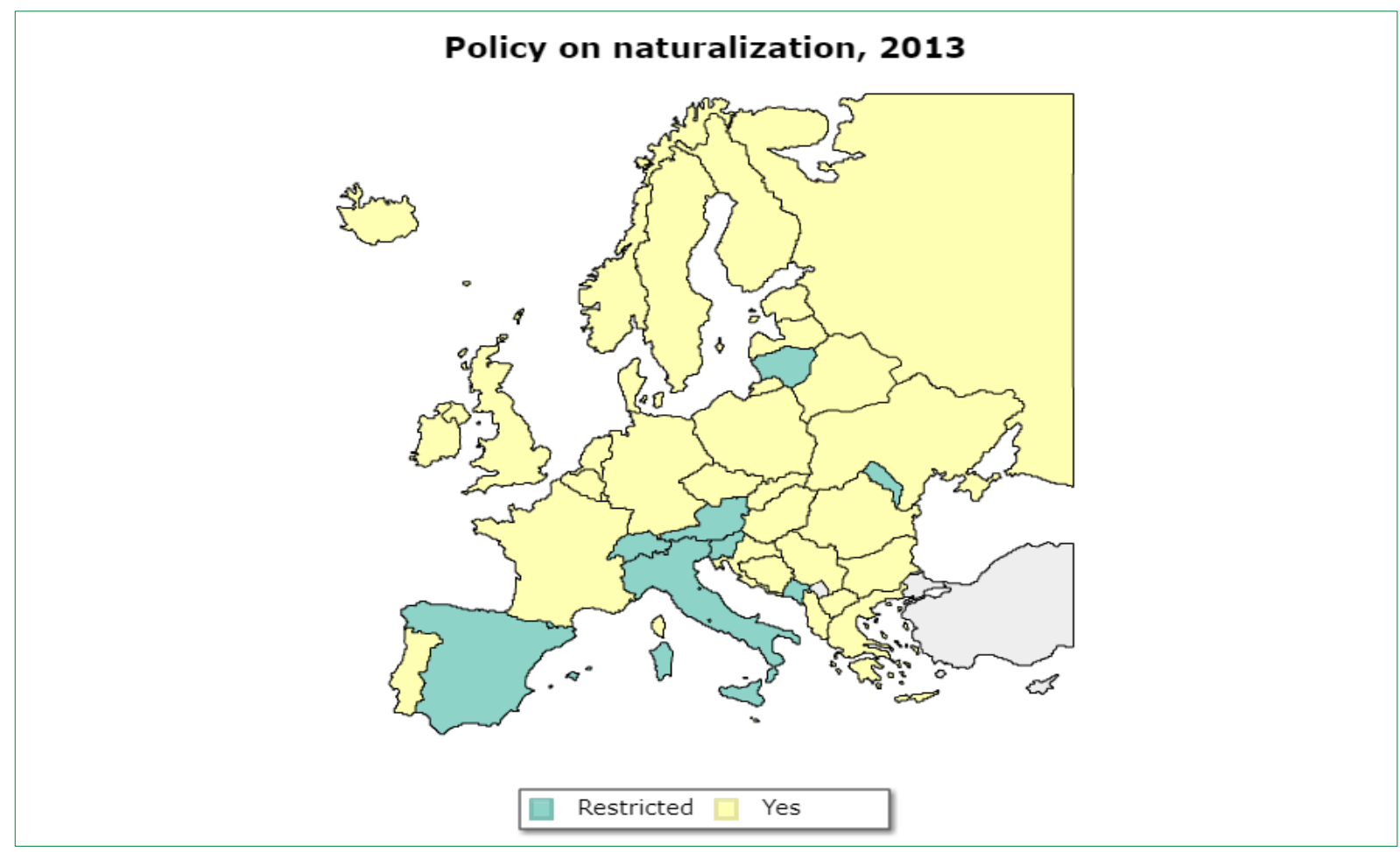

Figure 1. Policy on naturalization in Europe, 2013

Source: The figures were elaborated by the author based on the database UN DESA World Population Policies Database (https://esa.un.org/PopPolicy/about_database.aspx, accessed 10.05.2019)

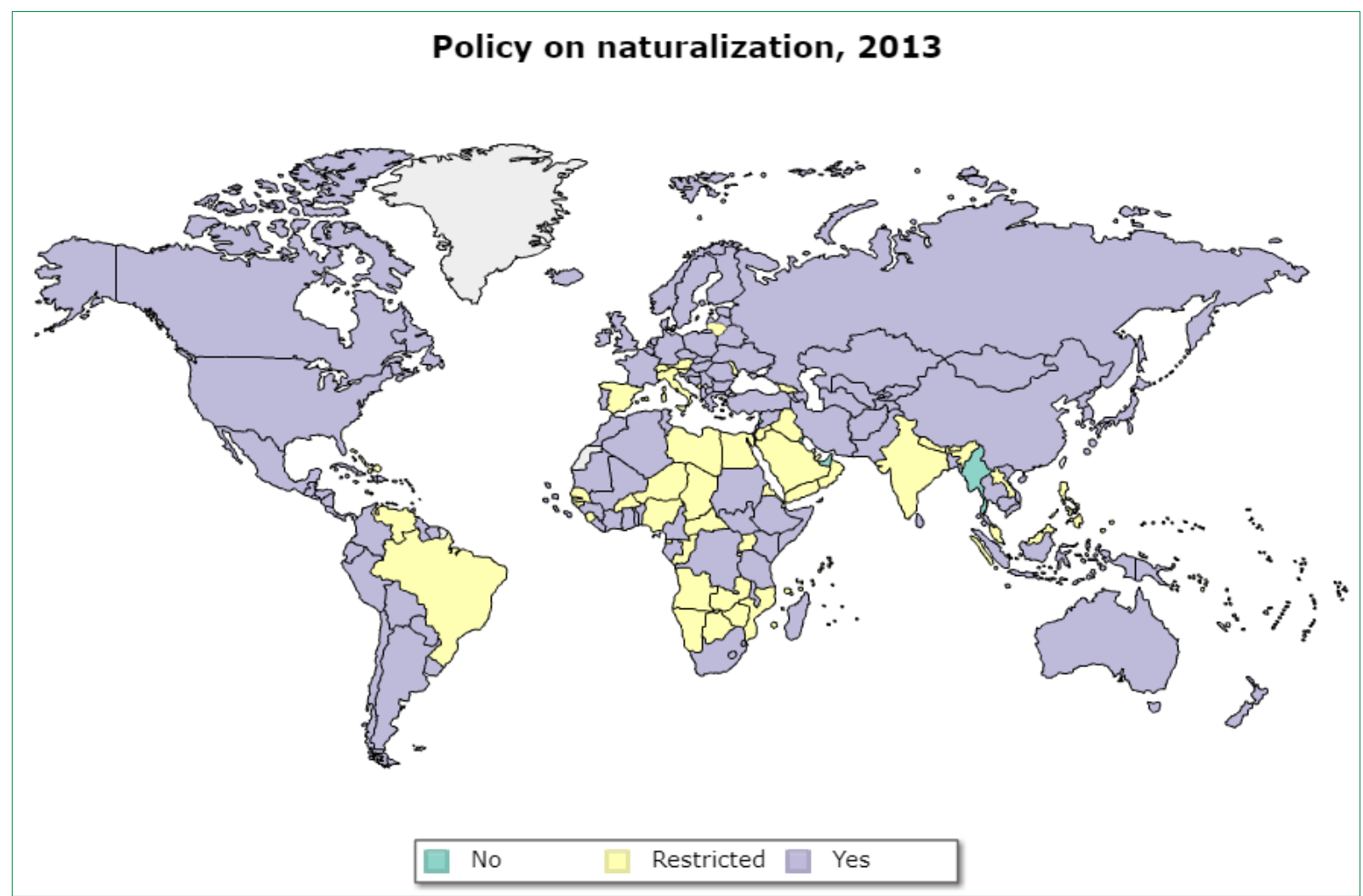

Figure 2. Policy on naturalization in World, 2013

Source: the figures were elaborated by the author based on the database UN DESA World Population Policies Database (https://esa.un.org/PopPolicy/about_database.aspx, accessed 10.05.2019) 
According to OECD International Migration Database, the number of persons who acquired citizenship in a foreign country over the past 30 years (1987-2016) amounts to 43.5 million. In 2008, for the first time, 2 million people were registered in OECD, and for the second time, 1 million people in USA, the first case being recorded in 1996. Data for 2013-2016 shows that 2 million persons annually acquired citizenship in other countries. The most cases were registered in USA $17.3 \mathrm{mln}(40 \%)$, Canada - $4.5 \mathrm{mln}(10 \%)$, UK and Australia, $3.2 \mathrm{mln}(7 \%)$ and $3.1 \mathrm{mln}(7 \%)$, in France and Germany - $2.8 \mathrm{mln}(6.5 \%)$ and $2.6 \mathrm{mln}(6 \%)$, Spain $-1.4 \mathrm{mln}$ and Italy $-1.2 \mathrm{mln}$, in Sweden and Netherlands - $1.0 \mathrm{mln}$ each, in Belgium $0.9 \mathrm{mln}$, Switzerland - $0.8 \mathrm{mln}$, New Zeeland and Austria - $0.5 \mathrm{mln}$ each.

There are significant regional differences in immigrants access rate to citizenship of the host country. It was estimated that about $80 \%$ of foreign population of Australia, Sweden and the Netherlands is naturalized after ten years of residence, in Canada - 89\%, Norway and UK - around 70\%, USA, Austria and Denmark - 50-60\%, France - 47\%, Switzerland and Germany - 35\% and $37 \%$, Luxembourg with only $12 \%$ (21, LIEBIG, T., VON HAAREN, F., 2011). In this context, it seems that Europe is differentiated by lower rates of naturalization compared to other economic developed countries. There are important scientific debates to understand whether these differences are due to individual characteristics of immigrants or policies adopted in destination and origin countries. Many studies have shown the importance of preserving the nationality of country of origin.

Dual citizenship. The opportunity to hold the citizenship of two countries at the same time is relatively recent. Human history reminds us that in the not-so-distant past, dual citizenship has been banned in most states of the world. In this regard, the Hague Convention of April 12, 1930, agrees that each person must have one citizenship and only one citizenship, and cases of statelessness and dual citizenship should be avoided. A large number of countries have revised their nationality laws in accordance with this Convention, most of them from the post-war era, including the USSR.

After the World War, on May 6, 1963, the Council of Europe adopted the Convention on the Reduction of Cases of Multiple Nationality and on Military Obligations in Cases of Multiple Nationality according to which nationals who have reached the age of majority and who acquire by their own will, through naturalization or recovery, the citizenship of another country cannot retain their citizenship. Also a person possessing the citizenship of two or more countries must renounce them with the consent of the part to which wishes to renounce.

From November 6, 1997, the Council of Europe adopts a new European Convention on Citizenship in which it is stipulated that each State is free to decide what consequences to assign if its citizens acquire or hold the citizenship of another country. In this way, the Council of Europe aims to achieve greater unity among its members and to avoid any form of discrimination on the grounds of citizenship by sex, religion, race, color, national or ethnic origin. In essence, this new convention agrees with dual citizenship.

Governments survey on World Population Policies conducted by UN DESA shows which governments allow their citizens to retain citizenship when acquiring another one, and if so, under what conditions or restrictions. Restrictions refer to: (i) the involved countries (accepting dual citizenship in the case of certain countries) or (ii) the rights involved (accepting dual citizenship with restrictions on full citizenship rights). The results are presented in Figures 3 and 4.

If we look at the situation in Europe in 2013, we notice that most states accept dual citizenship without any restrictions, only some countries, as the Netherlands, Austria, Germany, Czech Republic, Denmark, Norway, Spain, Poland, Belarus and Lithuania recognize dual citizenship with restrictions. Only three post-Soviet countries do not accept dual citizenship: Ukraine, Latvia and Estonia. Researching the situation in the world we find that most countries in the world have accepted dual citizenship without restrictions. Most states that do not recognize dual citizenship are from Asia and Africa. 


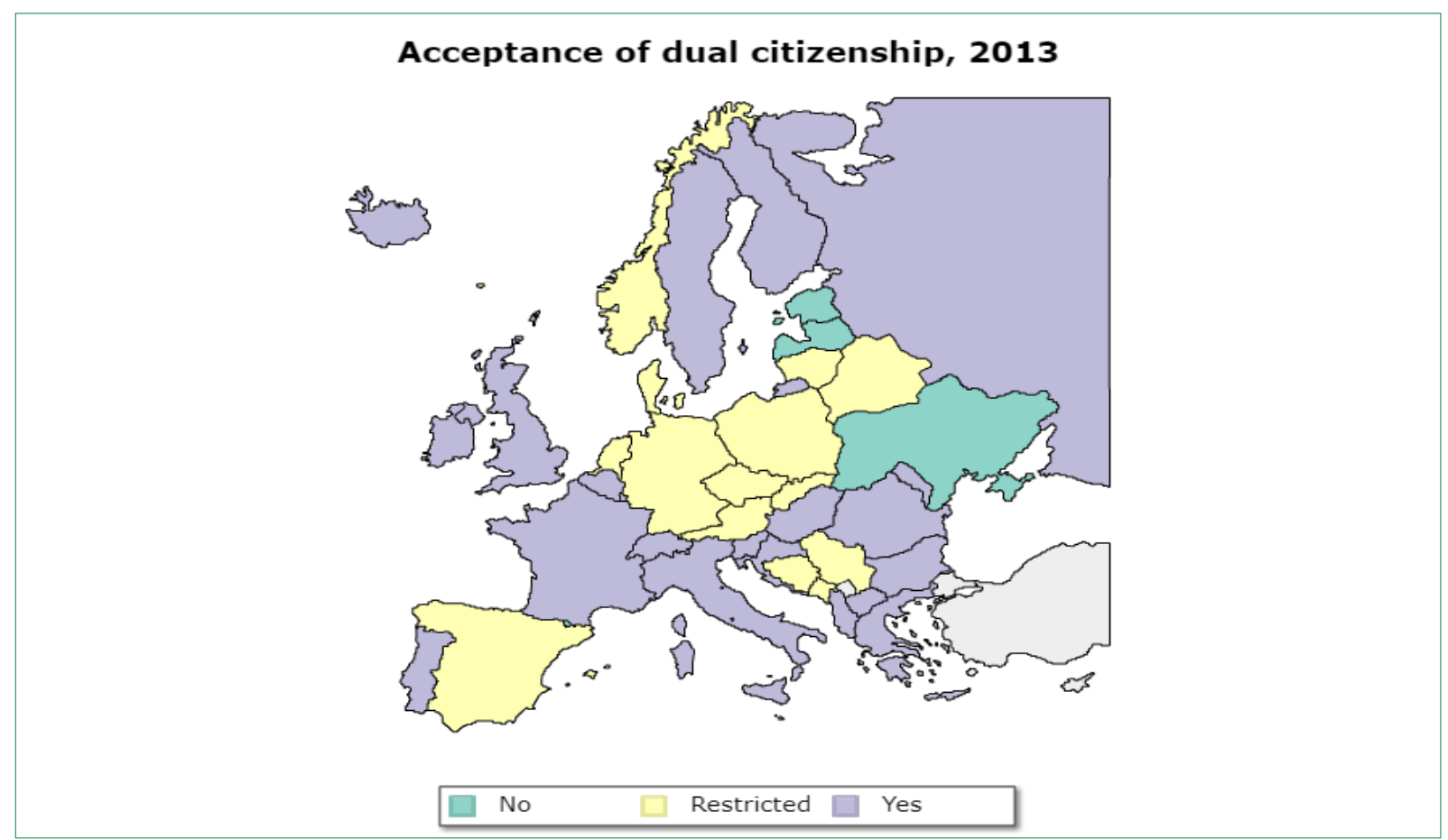

Figure 3. Acceptance of dual citizenship in Europe, 2013

Source: The figures were elaborated by the author based on the database UN DESA World Population Policies Database (https://esa.un.org/PopPolicy/about_database.aspx, accessed 10.05.2019)

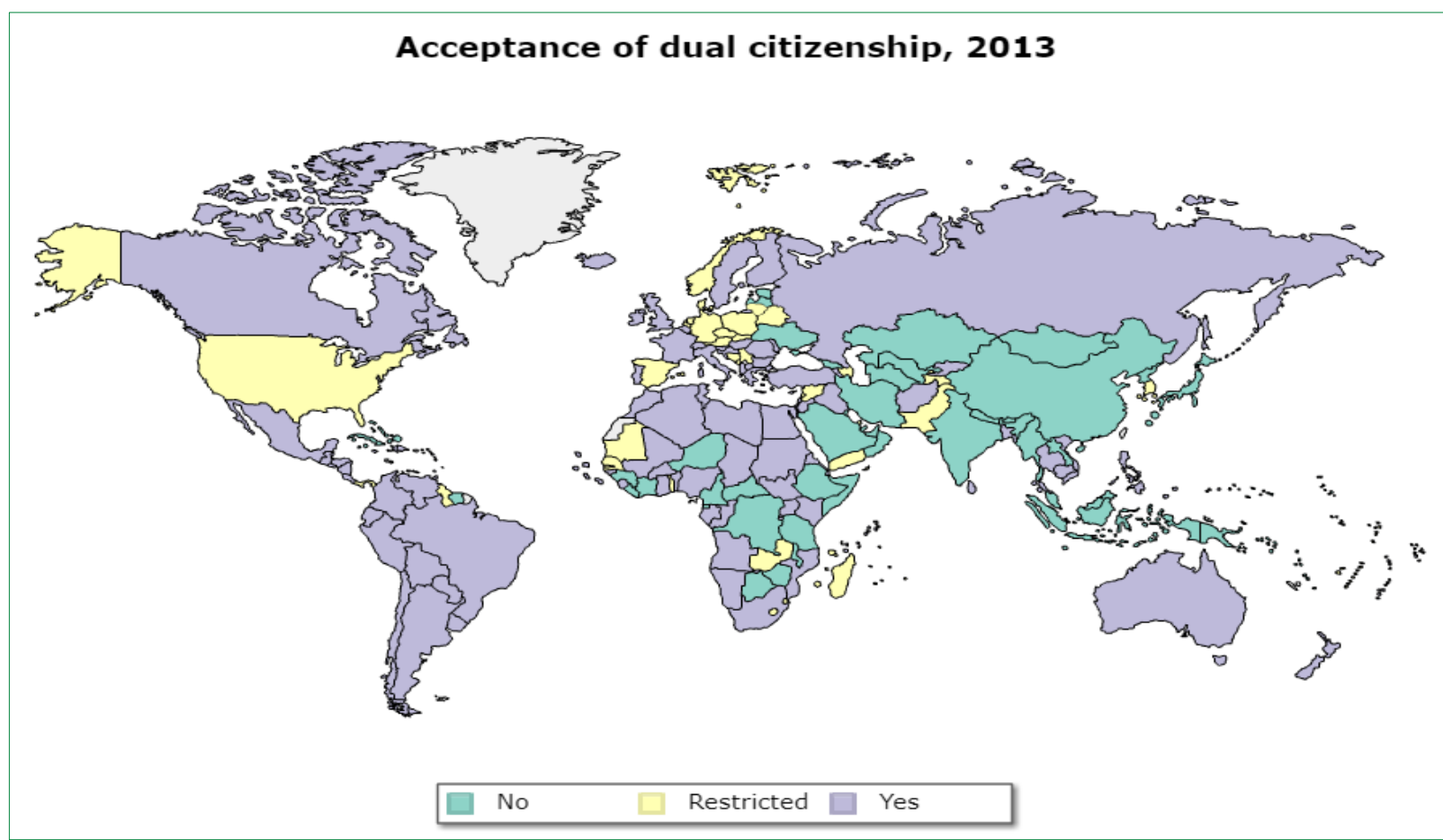

Figure 4. Acceptance of dual citizenship in World, 2013

Source: The figures were elaborated by the author based on the database UN DESA World Population Policies Database (https://esa.un.org/PopPolicy/about_database.aspx, accessed 10.05.2019)

Trends in Moldovan immigrant's access to foreign citizenship Acquiring the citizenship of another country by the citizens from Moldova became possible after 2002 when the Law was amended for this purpose. Until 2002, the Constitution limited the possibility to 
hold other citizenship without losing Moldovan citizenship, except in the cases provided by international agreements to which the Republic of Moldova is a party. Despite some public discussions about possible negotiations for a bilateral agreement on dual citizenship with Romania, Moldova has not signed such treaties (16, GASCA, V., 2012). The effect of the promoted policies is seen in the Figure 5 and Tabel 1, which shows the increased access to foreign citizenship since 2002.

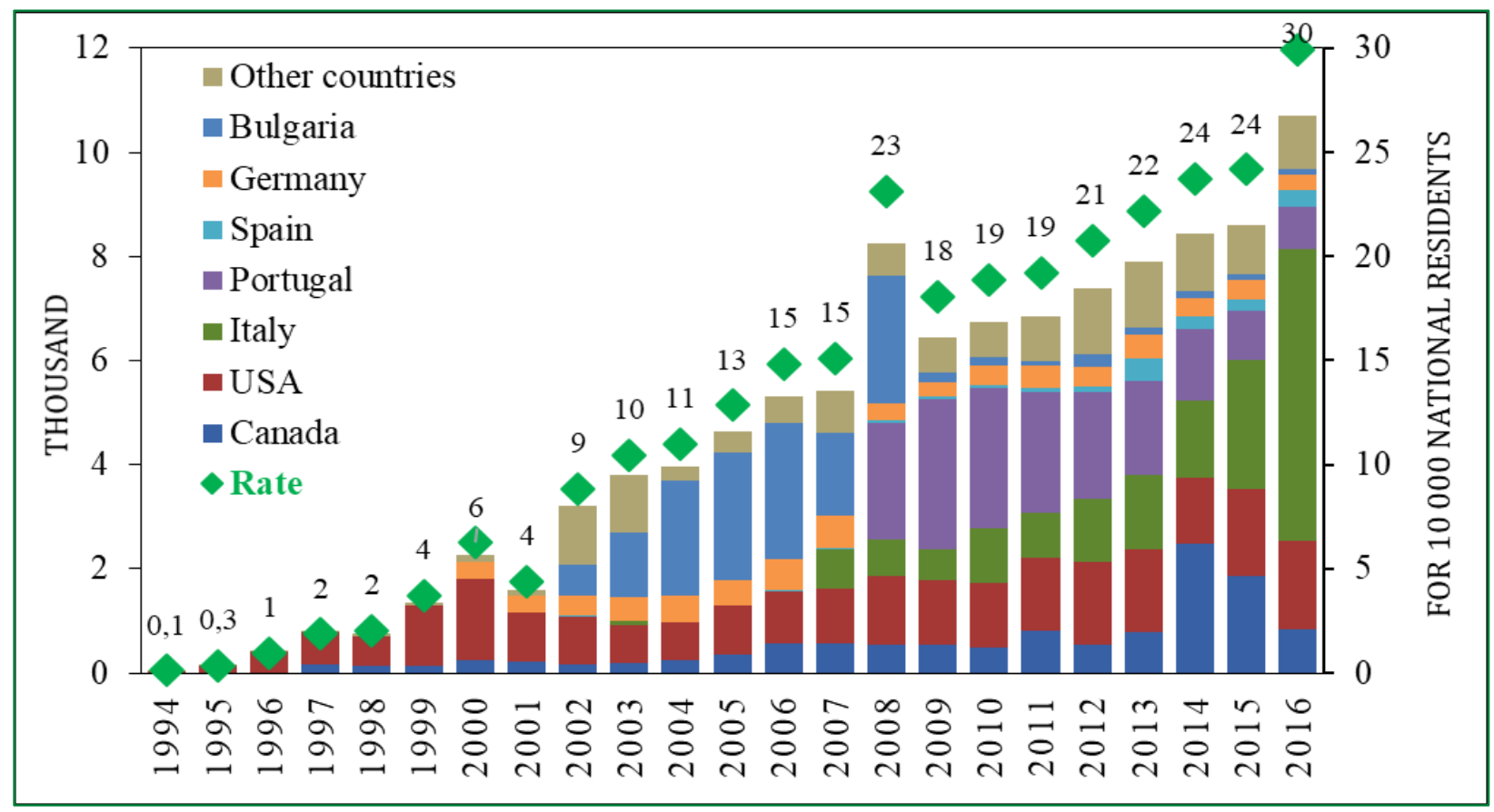

Figure 5. Acquisition of foreign citizenship by Moldovan citizens in 1994-2016 period Source: Author's estimates based on OECD International migration database, Eurostat and National Bureau of Statistics data.

Note: The rate is represented on the left axis.

Table 1

Acquisition of foreign citizenship by Moldovan citizens in selected period and countries (thousand and \%)

\begin{tabular}{|l|c|c|c|c|c|c|c|c|}
\hline \multirow{2}{*}{$\begin{array}{c}\text { Acquisition of } \\
\text { nationality by } \\
\text { country }\end{array}$} & \multicolumn{5}{|c|}{ thousand } & \multicolumn{5}{c|}{$\%$} \\
\cline { 2 - 10 } & $1994-2001$ & $2002-2008$ & $2009-2016$ & $1994-2016$ & $1994-2001$ & $2002-2008$ & $2009-2016$ & $1994-2016$ \\
\hline USA & 5,4 & 6,7 & 11,7 & 23,8 & 73,7 & 19,2 & 18,6 & 22,7 \\
\hline Canada & 0,9 & 2,7 & 8,3 & 11,9 & 12,4 & 7,7 & 13,2 & 11,4 \\
\hline Italy & & 1,6 & 14,7 & 16,2 & & 4,5 & 23,3 & 15,5 \\
\hline Portugal & & 2,2 & 14,9 & 17,1 & & 6,5 & 23,6 & 16,3 \\
\hline Bulgaria & & 13,1 & 1,1 & 14,3 & & 38,0 & 1,8 & 13,6 \\
\hline Germany & 0,6 & 3,3 & 2,9 & 6,9 & 8,5 & 9,6 & 4,6 & 6,5 \\
\hline Spain & & 0,1 & 1,5 & 1,6 & & 0,4 & 2,4 & 1,5 \\
\hline Greece & & 0,1 & 1,1 & 1,1 & & 0,1 & 1,7 & 1,1 \\
\hline United Kingdom & 0,1 & 0,5 & 0,8 & 1,5 & 1,5 & 1,4 & 1,3 & 1,4 \\
\hline France & 0,1 & 0,2 & 0,5 & 0,8 & 1,4 & 0,6 & 0,8 & 0,8 \\
\hline Belgium & & 0,3 & 0,5 & 0,8 & & 0,8 & 0,9 & 0,8 \\
\hline Czech Republic & 0,002 & 0,1 & 0,5 & 0,5 & 0,0 & 0,2 & 0,7 & 0,5 \\
\hline Other countries & 0,2 & 3,8 & 4,4 & 8,3 & 2,6 & 10,9 & 6,9 & 7,9 \\
\hline Total & 7.4 & 34,6 & 63.0 & 105,0 & 100.0 & 100,0 & 100,0 & 100,0 \\
\hline
\end{tabular}

Source: Author's estimates based on OECD International migration database and Eurostat. 
Romania is the country with the most citizenship requests from Moldovan citizens. Unfortunately, there are no official statistical data available to present the exact number of Moldovan citizens who also hold Romanian citizenship, but it is important to know that according to the Romanian Citizenship Law no. 21 of March 1, 1991, the citizens of the Republic of Moldova restore the Romanian citizenship, but do not acquire it. Pursuant to Article 11 of this law, at the regaining of the Romanian citizenship are entitled the persons who acquired it by birth and who lost it for reasons not attributable to them or this citizenship was taken away without their will, as well as their descendents up to the third generation, with possibility of retaining foreign citizenship and establishing their domicile in the country, or keeping it abroad. Thus, the recovery of Romanian citizenship is justified to be done by all persons from the Republic of Moldova who were born and lived in the territory of Romania until 1940 and their descendants up to the third generation.

The regaining of Romanian citizenship plays a very important role in the evolution of migration from Moldova, because it favors the legal migration in UE countries and work migration. The national survey The Barometer of Public Opinion held in April 2007 showed that $1.4 \%$ of the population owned Romanian citizenship, 9.8\% filed the documents for its regaining and 27.0\% intended to submit it. The reasons are free movement in the EU - 18.6\%, legal work in the EU $12.6 \%$, free movement in Romania - 4.7\%, identity and belonging to the Romanian people - $2.5 \%$. However, the massive phenomenon of regaining the Romanian citizenship cannot be considered and analyzed as an ordinary naturalization, since the method by which it is obtained refers to descendant born abroad.

As mentioned, there is no official and transparent source that systematically presents the situation regarding the regaining of Romanian citizenship by Moldovan citizens. Some statistical data are presented periodically in the media. In 2013, the Sorros Foundation Romania estimated at least 400 thousand Moldovan citizens who received Romanian passports during the period 19912012. Subsequently, the Romanian National Authority Citizenship announced that between 2002 and March 2018 Romanian citizenship was regained by about 521 thousand citizens from Moldova. In 2015-2017, about 175 thousand Romanian citizenships were conferred to citizens from Moldova (in 2015 - 45.5 thousand, in 2016 - 61.2 thousand, and in 2017 - 68.6 thousand).

Another specific situation is the acquisition of the citizenship of the Russian Federation by the Moldovan people. Since the break-up of the USSR, in Russia there have been adopted two important legislative acts on citizenship: between 1992-2002 it was in force the law adopted until the break-up of the Soviet bloc, and from 2002 the new law of citizenship was adopted. Russian experts evaluated the law promulgated in the USSR as extremely libertarian, with the procedure of acquiring citizenship very simplified and greatly favoring the inhabitants of the former Soviet countries (8, ČÛINOVSKIH, O.S., 2018), the people in these countries were enough between 3 months and 1.5 years to become Russian citizens.

In order to acquire Russian citizenship, it is imperative that foreigners turn 18 years old, to live uninterruptedly on the territory of the country for 5 years, to speak Russian, to have a legitimate source of livelihood and take an oath of respect for the Constitution of the Russian Federation. At the same time, the legislation also provides for the acquisition of citizenship in a simplified procedure for certain categories of applicants. In the case of the Moldovan population, the procedure for acquiring citizenship is simplified if in the past the applicant has held the citizenship of the USSR, as well as if they participated in the Program for support of voluntary resettlement to Russia of compatriots who live abroad, and has his / her residence in Russia. The data showed that $3.7 \%$ of the naturalized immigrants in Russia are citizens of the Republic of Moldova (8, ČÛDINOVSKIH, O.S., 2018).

At the same time, it is possible for the applicants to obtain citizenship through the foreign institutions of the Russian Federation (these are usually the consulates, embassies), while they are in the territory of the country of residence. This path was best accessed by the population on the left side of the Dniester (8, ČUDINOVSKIH, O.S., 2018). According to the data, over 400 thousand Moldovan citizens (including from Transnistria) acquired the Russian citizenship between 1992 and 2017 (Table 2). 
Persons from Moldova admitted to the Russian citizenship

\begin{tabular}{|c|c|c|c|c|c|c|c|c|c|c|c|}
\hline \multicolumn{3}{|c|}{$\begin{array}{c}\text { Ministry of the Interior/ Federal } \\
\text { Migration Service }\end{array}$} & \multicolumn{4}{|c|}{ Foreign institutions } & \multicolumn{4}{c|}{ Total } \\
\hline Year & Thousand & Year & Thousand & Year & Thousand & Year & Thousand & Year & Thousand & Year & Thousand \\
\hline 1992 & 0,02 & 2005 & 13,7 & 1992 & - & 2005 & 7,7 & 1992 & 0,02 & 2005 & 21,4 \\
\hline 1993 & 0,2 & 2006 & 12,8 & 1993 & - & 2006 & 20,2 & 1993 & 0,2 & 2006 & 33 \\
\hline 1994 & 3,1 & 2007 & 13,9 & 1994 & - & 2007 & 34,8 & 1994 & 3,1 & 2007 & 48,7 \\
\hline 1995 & 8,6 & 2008 & 15,8 & 1995 & - & 2008 & 19,7 & 1995 & 8,6 & 2008 & 35,5 \\
\hline 1996 & 7,7 & 2009 & 20,4 & 1996 & - & 2009 & 21,9 & 1996 & 7,7 & 2009 & 42,3 \\
\hline 1997 & 7,4 & 2010 & 2 & 1997 & - & 2010 & 12,8 & 1997 & 7,4 & 2010 & 14,8 \\
\hline 1998 & 7,1 & 2011 & 2,8 & 1998 & - & 2011 & 9,4 & 1998 & 7,1 & 2011 & 12,2 \\
\hline 1999 & 5,6 & 2012 & 5,3 & 1999 & - & 2012 & 3,7 & 1999 & 5,6 & 2012 & 9 \\
\hline 2000 & 7,1 & 2013 & 12,5 & 2000 & - & 2013 & 4,6 & 2000 & 7,1 & 2013 & 17,1 \\
\hline 2001 & 9 & 2014 & 13,7 & 2001 & - & 2014 & 5,3 & 2001 & 9 & 2014 & 19 \\
\hline 2002 & 6,7 & 2015 & 16,8 & 2002 & - & 2015 & 10,4 & 2002 & 6,7 & 2015 & 27,2 \\
\hline 2003 & 0,4 & 2016 & 23 & 2003 & 1,1 & 2016 & 15,4 & 2003 & 1,5 & 2016 & 38,4 \\
\hline 2004 & 7,3 & 2017 & 29 & 2004 & 5,3 & 2017 & 14,2 & 2004 & 12,6 & 2017 & 43,2 \\
\hline \multicolumn{3}{|c|}{ Total } & $\mathbf{2 5 1 , 9 2}$ & \multicolumn{3}{|c|}{ Total } & $\mathbf{1 8 6 , 5}$ & & Total & $\mathbf{4 3 8 , 4 2}$ \\
\hline
\end{tabular}

Source: the Table was elaborated by the author based on the data presented by Chudinovskikh 2018.

USA and Canada offered citizenship to immigrants born in Moldova with a higher frequency even if the intensity of migration in these countries is lower compared to other countries, for example Italy, Portugal and Germany. Most likely, the answer in this situation is the relatively simple naturalization process among international standards in both Canada and the USA. To become eligible for citizenship, a person must be 18 years old and 5 years of continuous residence in the USA and 3 years (of the last 4 years) in Canada (23, PICOT, G., HOU, F., 2011). Other important conditions are knowledge of English (or French for Canada), knowledge of history and institutions, participation and oath taking, loyalty to the state, lack of criminal record in Canada. At the same time, the children of immigrants born in the US or Canada automatically obtain the citizenship of the respective countries.

The number of naturalized persons during the whole period analyzed is estimated at almost 24 thousand in the USA and 12 thousand in Canada. Of the total number of naturalized migrants in the period 2002-2016, about 19\% occurred in the US and 8-13\% in Canada (Table 2).

There are known several periods when immigrants to the US were naturalized in greater numbers, namely the years 1999-2000, 2012-2013 and the last years 2015-2016. The majority of immigrants who acquired citizenship in 1999-2000 arrived between 1991 and 1994 (86\% and 91\%, respectively).

This increase was due, on the one hand, to improving the conditions for processing applications, and on the other hand to the 1996 legislative changes (PRWORA), which canceled many privileges for non-US citizens, which encouraged immigrants to gain citizenship (14, ENCHAUTEQUI, M.E., GIANNARELLI, L., 2015; 5, BLOEMRAAD, I., 2006). In the other two periods, the increase of naturalization is closely related to the increase of the migration flows. In 2005-2006 there were two large flows of immigrants of about 3.5 and 3.0 thousand people, the majority being refugees and asylum seekers (29, TABAC T., 2015), which caused the increase of naturalization in 2012-2013. This tendency can be followed permanently in the USA, the increase of the migratory flows leads respectively to the growth of the naturalized persons in the following years. Based on these findings, we can consider that the migrants from the Republic of Moldova have motivation and desire to stay in the USA, and the citizenship is an opportunity in this regard.

In the case of Canada, the trend of naturalization has been stable throughout the years except for 2014 and 2015, when the number of naturalizations increased by $220 \%$ and $140 \%$, respectively. We can assume that the situation occurred due to the intensification of the migration flows in 2009 and 2010 by $36 \%$ and $76 \%$, respectively. However, during this period the processing fee has been changed 
and the cost for citizenship has increased significantly, and when a new amendment comes into effect, there may be an increase in demand before the new requirement comes into effect, and a decline after that, as shown in the data presented below.

Southern Europe: Italy, Portugal, Spain and Greece. To become eligible for citizenship in these countries it takes a period of residence of 6-7 years for Portugal and Greece and ten years of residence in Italy and Spain (in Italy the period is reduced to four years for citizens from EU countries). Other conditions: sufficient knowledge of the national language (for Portugal), as well as the culture and history of the country (for Greece), no criminal records of certain crimes (Italy, Portugal and Greece), stable and sufficient income (Italy and Greece), to prove adequate social integration (Portugal and Spain). For Spain it is especially important the oath of loyalty to the King and obedience to the Constitution and renouncing to the citizenship of the country of origin. All these countries, except Italy, ask persons applying for naturalization to demonstrate that they are integrated into society based on an integration test (24, PASCOUAU, Y., BRUYCKER, P., 2011).

The naturalization of immigrants in Southern European countries began in the second half of the 20th century due to the fact that immigration to these territories is a relatively new phenomenon (27, Tabac T., 2018) considering that the Republic of Moldova has gained independence from the Soviet bloc recently. At the same time, an important factor in this situation is the public policies that regulate more restrictive naturalization procedures, compared to the countries analyzed above (in Italy and Spain it takes 10 years of legal residence while in Spain it is also required to renounce to the previous citizenship). From the data we can see that immigrants started to acquire citizenship in Portugal first, the period of intensive naturalization being observed between 2008-2013. The naturalization of immigrants in Italy increased with 2012, which means ten years from Law No.189 of July 30, 2002 (Bossi-Fini Law), famous for the amnesty offered to illegal immigrants. From the data it is also observed the increase of naturalization up to 5.6 thousand in 2016, a highly significant increase in our case. For the whole analyzed period, 16.2 thousand immigrants acquired the Italian citizenship and 17.1 thousand the Portuguese citizenship. The citizenship of Spain and Greece was acquired by a very small number of immigrants, 1.6 thousand and 1.1 thousand, respectively, because in Spain the conditions are harsher, whereas in Greece the immigration was the lowest.

Western Europe: Germany, Belgium, France and the UK. In the recent years, an intensification of the migration flows from Moldova to this region is registered, largely due to the increase of the number of Romanian citizens (27, Tabac T., 2018). From this reason, we consider necessary an analysis of the current state regarding the acquisition of the citizenship of these countries.

To become a citizen in Belgium, France and the UK it is required a minimum of five years of continuous residence, while in Germany - eight years (ten years until 2000). Other specific requirements besides the knowledge of the language of the country, socio-economic integration, lack of criminal convictions, it is necessary to know the constitutional rights and duties in the case of France, and the intention to have the main domicile in the case of the UK. The conditions for acquiring the citizenship of Germany are tougher than in the other countries. Besides the fact that the knowledge of the German legal system and the demonstrated ability to support oneself and family without requesting for unemployment benefits are required, a mandatory condition is to give up to the citizenship of the country of origin. However, the largest number of immigrants from Moldova to Western Europe have acquired German citizenship. Between 1994-2016, 6.9 thousand immigrants have acquired German citizenship, 1.5 thousand UK citizenship and 0.8 thousand each - French and Belgian citizenship. Immigrants to Germany also gain citizenship through cultural-ethnic affinity. That is, German ethnic immigrants from Eastern Europe who, with the break-up of the Soviet bloc, settled in Germany on the basis of a special certificate have the opportunity to automatically acquire citizenship through descents. However, renouncing another citizenship is required. According to Statistisches Bundesamt, about $90 \%$ of immigrants obtain citizenship through naturalization, the proportion of naturalization being estimated at 3-5\% of the stock of immigrants from Moldova (28, Tabac T., 2017).

Other countries of naturalization in the analyzed period are Bulgaria (14.3 thousand), Ireland (2.3 thousand), Turkey (2.1 thousand), Czech Republic ( 0.5 thousand), Netherlands and Australia (each 0.4 thousand). In Bulgaria it is registered the largest number due to the simplified rules for offering citizenship since 2001, the mode of acquisition of citizenship is "by origin" and it implies the 
demonstration of ethno-cultural affinity with the Bulgarian nation. Although Moldovan emigration to Bulgaria has not been registered, the number of naturalized persons is close to that of Portugal and Italy. Many have acquired Bulgarian citizenship for emigration and legal work in EU countries.

To become a citizen in the Czech Republic it is necessary to renounce the citizenship of another country, which motivates the Moldovan immigrants to access Czech citizenship. In this case, we can support the negative influence of policies because the flows of immigrants to the Czech Republic have always been at the level of flows in Portugal (27, Tabac T., 2018). The situation is also specific in the Netherlands because it is required to renounce the citizenship of another country if it exists, but the number of immigrants in this country is not significant either.

The conditions of citizenship in Ireland and Australia are relatively simple. There are required from two years (in Australia) to five years of residence (in Ireland), expressed intention to remain in the country, good character and loyalty to the state.

Insufficient statistical data does not allow us to mention the exact number of people who obtained citizenship in Turkey during the analyzed period, only data for 2002 and 2003 shows about 970 and 900 , respectively. Such growth certainly represents changes in the level of policies promoted.

\section{CONCLUSIONS}

In the context of the ones mentioned in this paper we conclude that at present, a significant number of Moldovan citizens also possess the citizenship of another state. The anticipated estimates that we have at the moment allow us to consider that their number can be 1 million people, with some variations. Reporting to the stable population of the country, this number represents $1 / 3$ of the total. Of course, the policies promoted by the other states had a great impact and for some countries it was not necessary for the citizen to be a classical immigrant established and integrated in the society. The case of Romania, but also of Bulgaria, is quite specific in this context because the acquisition of citizenship is made in line with ethnic and cultural origins with the respective countries. At the same time, the naturalization of immigrants in the Russian Federation was favored on the one hand by facilitated policies for the former USSR, and on the other hand by the socio-cultural similarities between the populations of these societies (knowledge of the Russian language, similar values and so on).

About a classic process of naturalization in which an immigrant must demonstrate eligibility for citizenship through socio-economic integration we can speak in the context of European and overseas countries. Here, the impact of policies promoted by the countries of destination is observed too, and in this respect Canada and USA differ from most EU countries by less austere naturalization policies. We consider that the naturalization of immigrants in the EU is low compared to the annual flows that go here and the stocks formed over the years. Immigrants from Moldova have demonstrated that they can successfully integrate socially and economically in all emigration countries and European countries are not an exception. We also want to emphasize the importance of tolerance towards dual citizenship (which exists both in the Republic of Moldova and in most of the host countries) as a determining factor in accessing foreign citizenship by Moldovan immigrants.

Acquiring the citizenship of developed countries offers various benefits to immigrants from Moldova, therefore the proportion of naturalizations is constantly increasing. The most important benefit is considered the mobility without barriers at international level, or in the case of the Republic of Moldova there are travel restrictions in the most countries of the world. The citizenship of a European country favors not only the visits, but also the employment in any of the EU countries, insurance,social and legal protection in the country of destination, as well as the opportunity of migration for settlement. These benefits are important for Moldovan migrants considering the poor socioeconomic situation and political instability in the country.

To our best knowledge, this is the first study that addresses the acquisition of foreign citizenship by Moldovan immigrants and indicates the need to develop in perspective the analyzes on the economic and social benefits of naturalization. It is also important and useful to know the extent to which naturalization can increase among immigrants eligible for naturalization. The longer the immigrants are in the host country, the more the opportunity for naturalization increases. Equally important is the knowledge of the socio-economic characteristics of naturalisers. 


\section{REFERENCES}

1. BAUBOCK, R. et al. Migration and Citizenship: legal status, rights and political participation. Amsterdam: Amsterdam University Press, 2006. 128 p. ISBN 9789053568880.

2. BEVELANDER, P. Naturalisation and Social Inclusion. Naturalisation: A Passport for the Better Integration of Immigrants? Paris: OECD, 2010, pp. 237-250. [Accesat 29.03.2019]. Disponibil: doi.org/10.1787/9789264099104-en

3. BEVELANDER, P., DEVORETZ, D.J. The Economics of Citizenship. Malmo: Malmo University, 2008. ISBN 978-91-7104-079-4.

4. BEVELANDER, P., VEENMAN, J. Naturalization and Immigrants' Employment Integration in the Netherlands. In: Journal of International Migration and Integration. 2006, vol. 7 (3), pp. 327-349. ISSN 1874-6365. [Accesat 15.04.2019]. Disponibil: doi.org/10.1007/s12134-006-1016-y

5. BLOEMRAAD, I. Becoming a Citizen in the United States and Canada: Structured Mobilization and Immigrant Political Incorporation. In: Social Forces. 2006, vol. 85 (2), pp. 667-695. ISSN 1534-7605. [Accesat 19.06.2019]. Disponibil: doi:10.1353/sof.2007.0002

6. BRATSBERG, B., RAGAN, Jr., J.F., NASIR, Z.M. The effect of naturalization on wage growth: A panel study of young male immigrants. In: Journal of Labor Economics. 2002, vol. 20 (3), pp. 569-597. ISSN 1537-5307. [Accesat 29.03.2019]. Disponibil: https://www.journals.uchicago.edu/doi/abs/10.1086/339616

7. CHISWICK, B.R., MILLER, P.W. Citizenship in the United States: The Role of Immigrant Characteristics and Country of Origin. IZA Discussion Paper. 2008, no. 3596. [Accesat 12.05.2019]. Disponibil: https://www.emerald.com/insight/content/doi/10.1108/S01479121(2009)0000029007/full/html

8. ČÛDINOVSKIH, O.S. Statistika priobreteniâ graždanstva kak otraženie osobenostej migracionoj politiki Rossii. V: Voprosy Statistiki. 2018, № 25 (9), ss. 3-26. ISSN 2313-6383.

9. DELEU, Ecaterina. Generații secunde de migrație: cazul Republicii Moldova. Institutul de Cercetări Juridice și Politice al Academiei de Științe a Moldovei. Chișinău, 2017. 344 p. ISBN 978-9975-53-777-3.

10.DEROOIJ, E.A. Patterns of Immigrant Political Participation: Explaining Differences in Types of Political Participation between Immigrants and the Majority Population in Western Europe. In: European Sociological Review. 2012, vol. 28 (4), pp. 455-481. ISSN 1468-2672. [Accesat 29.03.2019]. Disponibil: https://doi.org/10.1093/esr/jcr010

11.DEVORETZ, D.J., PIVNENKO, S. The Economic Determinants and Consequences of Canadian Citizenship Ascension. In: The Economics of Citizenship. Malmo: Malmo University, 2008, pp. 23-61. ISBN 978-91-7104-079-4. [Accesat 12.05.2019]. Disponibil: https://pdfs.semanticscholar.org/8dff/d7931b3bd120a13e1b61189096e6d27ec046.pdf

12.DEVORETZ, D.J., PIVNENKO, S. The Economic Causes and Consequences of Canadian Citizenship. In: Journal of International Migration and Integration. 2005, vol. 6 (3-4), pp. 435-468. ISSN 1874-6365. [Accesat 11.03.2019]. Disponibil: https://link.springer.com/article/10.1007/s12134-005-1021-6

13.European Demographic Data Sheet. 2018. [Accesat 15.07.2019]. Disponibil: http://www.populationeurope.org/

14.ENCHAUTEQUI, M.E., GIANNARELLI, L. The Economic Impact of Naturalization on Immigrants and Cities. Urban Institute. 2015, december. 38 p. [Accesat 11.03.2019]. Disponibil: https://www.urban.org/sites/default/files/publication/76241/2000549-The-Economic-Impact-ofNaturalization-on-Immigrants-and-Cities.pdf

15.GAGAUZ, O., STRATAN, A., BUCIUCEANU-VRABIE, M., PENINA, O., CIUBOTARU, V., CHEIANUA-ANDREI, D. Population Situation Analysis in the Republic of Moldova. Chișinău, 2016. 174 p. [Accesat 11.03.2019]. Disponibil: https://moldova.unfpa.org/sites/default/files/pub-pdf/PSA_engleza.pdf

16.GASCA, Viorelia. Country report: Moldova. EUDO Citizenship Observatory. 2012, november. [Accesat 21.06.2019]. Disponibil: http://eudo-citizenship.eu/docs/CountryReports/Moldova.pdf

17.GUIMEZANES, N. The current status of nationality law. In: Naturalisation: A Passport for the Better Integration of Immigrants? Paris: OECD, 2011, pp. 65-95. [Accesat 11.03.2019]. Disponibil: https://www.oecd-ilibrary.org/docserver/9789264099104-

en.pdf?expires=1577353393\&id=id\&accname=oid034021\&checksum=EFF3183DCDCF29F7611933 5DCFF65B5B

18.HAINMUELLER, J., LAWRENCE, D. et al. A randomized controlled design reveals barriers to citizenship for low-income immigrants. In: PNAS. 2018, vol. 115 (5), pp. 939-944. [Accesat 11.03.2019]. Disponibil: doi.org/10.1073/pnas.1714254115 
19.JONES-CORREA, M. Under Two Flags: Dual Nationality in Latin America and Its Consequences for Naturalisation in the United States. In: The International Migration Review. 2001, vol. 35 (4), pp. 997 1029. [Accesat 11.03.2019]. Disponibil: doi.org/10.1111/j.1747-7379.2001.tb00050.x

20.KERNO, I.S. Nationality, including Statelessness - Analysis of Changes in Nationality Legislation of States since 1930. United Nations. 1957. [Accesat 24.05.2019]. Disponibil: http://legal.un.org/ilc/documentation/english/a_cn4_67.pdf

21.LIEBIG, T., VON HAAREN, F. Citizenship and the Socioeconomic Integration of Immigrants and Their Children. In: Naturalisation: A Passport for the Better Integration of Immigrants? Paris: OECD, 2011, pp. 23-57. [Accesat 24.05.2019]. Disponibil: doi.org/10.1787/9789264099104-en

22.MAZZOLARI, F. Dual Citizenship Rights: Do They Make More and Richer Citizens? In: Demography. 2009, vol. 46 (1), pp. 169-191. ISSN 1533-7790. [Accesat 24.05.2019]. Disponibil: doi.org/10.1353/dem.0.0038

23.PICOT, G., HOU, F. Citizenship Acquisition in Canada and the United States: Determinants and Economic Benefit. In: Naturalisation: A Passport for the Better Integration of Immigrants? Paris: OECD, 2011, pp. 153-182. [Accesat 24.05.2019]. Disponibil: doi.org/10.1787/9789264099104-en

24.PASCOUAU, Y., BRUYCKER, P. Integration and Acces to Nnationality in EU Member Countries. In: Naturalisation: A Passport for the Better Integration of Immigrants? Paris: OECD, 2011, pp. 251-259. [Accesat 14.07.2019]. Disponibil: doi.org/10.1787/9789264099104-en

25.SCOTT, J.B. Nationality: Jus Soli or Jus Sanguinis. In: The American Journal of International Law. 1930, vol. 24 (1), pp. 58-64. [Accesat 14.07.2019]. Disponibil: https://www.jstor.org/stable/2189299?seq=1

26.STEINHARDT, M.F., WEDEMEIER, J. The Labor Market Performance of Naturalized Immigrants in Switzerland - New Findings from the Swiss Labor Force Survey. In: Journal of International Migration and Integration. 2011, vol. 13, pp. 223-242. ISSN 1874-6365. [Accesat 14.07.2019]. Disponibil: doi:10.1007/s12134-011-0213-5

27.TABAC, Tatiana. Long-term migration from Republic of Moldova and Romania. In: The Yearbook of the Gh. Zane Institute of Economic Research. 2018, vol. 27, pp. 79-90. [Accesat 14.07.2019]. Disponibil: https://ideas.repec.org/a/zan/ygzier/v27y2018i1p79-90.html

28.TABAC, Tatiana. Migrația populației din Republica Moldova în Germania în anii 1992-2016. In: Creșterea economică în condițiile globalizării: modele de dezvoltare durabilă: conferința internațională științifico-practică. Sesiunea științifică "Dinamica populației și calitatea potențialului uman", 12-13 octombrie 2017. Ediția a XII-a, Chisinau: INCE, 2017, pp. 133-141. ISBN 978-9975-3171-7-7.

29.TABAC, Tatiana. Moldovenii în "Țara visurilor". In: Populație și Dezvoltare: Buletin informativ. Chișinău: CCD, UFPA, 2015, nr. 2, pp. 5-7. [Accesat 14.07.2019]. Disponibil: http://demografie.md/files/files/bi2015.pdf

30.TRAN, K., KUSTEC, S., CHUI, T. Becoming Canadian: Intent, Process and Outcome. In: Canadian Social Trend, Statistics Canada Catalogue. 2005, no. 11-008, 76, pp. 8-13. [Accesat 14.07.2019]. Disponibil: https://www150.statcan.gc.ca/n1/en/pub/11-008-x/11-008-x2004004-eng.pdf?st=Ydhp0u7M

31.VINK, M.P., PROKIC-BREUER, T., DRONKERS, J. Access to Citizenship and the Role of Origin Countries. In: Migrant Integration Between Homeland and Host Society. 2017, vol.1, pp. 201-224. [Accesat 14.07.2019]. Disponibil: doi:10.1007/978-3-319-56176-9_9

32.VINK, M.P., PROKIC-BREUER, T., DRONKERS, J. Immigrant Naturalization in the Context of Institutional Diversity: Policy Matters, but to Whom? In: International Migration. 2013, vol. 51 (5), pp. 1-20. [Accesat 23.07.2019]. Disponibil: doi: 10.1111/imig.12106

33.VINK, M.P., DRONKERS, J. Explaining access to citizenship in Europe: How citizenship policies affect naturalization rates. In: European Union Politics. 2012, vol. 13 (3), pp. 390-412. ISSN 1741-2757. [Accesat 23.07.2019]. Disponibil: doi.org/10.1177/1465116512440510

34.YANG, P.Q. Explaining Immigrant Naturalization. In: The International Migration Review. 1994, vol. 28 (3), pp. 449-477. ISSN 1747-7379. [Accesat 23.07.2019]. Disponibil: doi:10.2307/2546816

\section{ARTICLE HISTORY}

Received 12 November 2019

Accepted 24 December 2019 


\section{OTHER \\ COMPARTIMENTS}




\title{
REVIEW 1 \\ of the monograph "FOOD SECURITY MANAGEMENT" \\ of Maria OLEINIUC, PhD in Economics, Associated Professor, Republic of Moldova
}

\author{
Reviewer: \\ Dragoș CIMPOIES, Habilitation in Economics, Professor, \\ The State Agricultural University of Moldova \\ email: dcimpoies@gmail.com
}

\section{Oleiniuc, Maria}

Managementul securităţii alimentare: Monografie / Oleiniuc Maria; red. şt.: Perciun Rodica; Inst. Naţ. de Cercet. Econ. - Chişinău: INCE, 2019. - 264 p.: tab.

Bibliogr.: p. 199-208 (206 tit.). - 100 ex.

ISBN 978-9975-3305-5-8.

$338.43+351.778 .2$

$0-42$

The monography is a synthesis of the theoretical approaches regarding food security, the analysis of the legal and normative framework existing at both international and national level. Also, an applied research on the management of food security assurance was carried out at the current stage of socioeconomic development in regional and national context.

Keywords: food security, economic security, sustainable development, economic crises, food security management, security risks.

The undersigned, Dr. Habilitate, prof. Dragoș Cimpoieș, after examining the monograph "Food Security Management" written by Mrs. Maria Oleiniuc, PhD, assoc. prof., I formulate the following assessments, conclusions and proposals.

This work is the result of a laborious activity. The researched branch is of a particular economic and social importance. The ensurance of food security is a problem faced by modern society not only globally but also at each country level.

The first chapter of the book reflects the main conceptual delimitations of food security, economic security and sustainable development. Within this chapter, the author refers to the ideas of the main international and local researchers such as: Strange T., Bayley A., Norgaard R., Baranovschii A. G., Danilova-Daniliana V., Pisculova N., Pohoață I., Dobrota N., Gavrilă-Paven I., Petre R., Burja V., Dinga E., Stratan A., Perciun R., Bajura T., Babii L., Boincean B. The author also refers to the link between the conceptual trilogy: economic security, food security and sustainable development.

The author's concern in Chapter 2 focuses on the influence and consequences of global food security risks. Thus, the author reviews the problems faced by the modern society on ensuring food security due to environmental risks: drought, floods, climate change, etc. and the consequences. At the same time, in this chapter the author studies the normative, institutional frameworks and the existing policies on ensuring food security. Of a particular importance is the current legislation on food security at EAC and CIS countries.

In Chapter 3, entitled "Diagnosing Global Food Security", the author focusing on SDO (Sustainable Development Objectives) highlights the correlation between the food security and the sustainable development indicators. The author assesses the situation regarding the development level of the agrofood complex worldwide. A fairly eloquent analysis is made by the author about the level of food security and the consequences of food insecurity such as: obesity, malnutrition, etc. and the most affected countries. As a result, the picture we receive shows that the countries with the highest level of food insecurity are third world countries.

\footnotetext{
${ }^{1}$ Date received: May 2019.
} 
Chapter 4 is dedicated to the food security analysis in the Republic of Moldova. A particular attention is paid to the characteristics of the institutional framework and regulations regarding the activity of the indigenous agricultural sector under conditions of sustainable development. Here are analyzed the risks related to ensuring national food security. Further, the author assesses the development dynamics of the agri-food complex of the Republic of Moldova, focusing on different periods of development of the country depending on the economic system existing in the period.

Chapter 5 represents the author's reflections on a model for analyzing food security at the regional level of the Republic of Moldova. It is worth attracting a special attention to paragraph 5.1. In order to be aware of the development level of the main pillars of food security at regional level, the author comes with a "product" such as the "Food Security Insurance Atlas of the Republic of Moldova", which can serve as a tool for analyzing the current situation not only from an agronomic but also social point of view.

In conclusion, I can say that this is a reference, which is distinguished by a personal footprint, reflected on each page of the paper. Through the content of ideas, through approaches and analyzes, the monograph "Food security management" represents a scientific value and is a special contribution in the literature. 


\section{REGULATION \\ of publication scientific articles in „Economy and Sociology" journal, category $B$, indexed in international databases}

\section{Presentation of the manuscript and decision on publication}

Authors wishing to publish articles in the Economy and Sociology journal are asked to send manuscripts electronically to incemd.redactie.es@gmail.com.

They can also be mailed or handed over to the editorial board on paper and in electronic form. Manuscripts run the peer-review process and the authors get a response in about 4 weeks.

By sending the manuscript to the editorial office, the responsible author confirms that he has read and agrees with the ethics of publication published in the journal Economy and Sociology.

All the manuscripts received are reviewed by the editorial staff in terms of meeting the formal requirements of the journal. Articles that do not match the journal's topic and are not written in accordance with the journal's rules are not accepted for review, and the respective notice is sent to the author.

The articles accepted for examination are discussed at the editorial board meeting where the reviewers are appointed.

After reviewing the article (peer review, double blind), the comments and objections of the reviewers and the Editorial board are sent to the author with a proposal to make corrections to them or to repeatedly submit the article. If the manuscript is not accepted for publication, a motivational refusal is sent to the author.

After the article is accepted, the author must send the editorial (if any) files with diagrams and data for them.

The finally print

The layout of the articles accepted for publication (after review and final drafting by authors) is sent to the authors for the fine print. The authors are asked to reply to the editorial office within 3 days.

The authors receive 1 copy of the article (extracted in pdf) and a journal.

Agreement for publication

The copyright for published articles belongs to the National Institute for Economic Research. Reprinting of the materials is possible only with the Editorial board's approval. Authors submitting articles to the editorial office implicitly declare their consent under these conditions.

Access to the contents of the journal

Access to the contents of the magazine is free on-line, the print version can be purchased with payment to the NIER Editorial Complex, including the order sent to the applicants or by subscription.

The editor of the journal, the National Institute for Economic Research, performs the electronic backup copy and will provide access to the contents of the journal if it will not be published.

Submissions are accepted all year round with the current waiting time of max. 6 months.

\section{publishing.}

There are no author fees or charges required for manuscript processing and/or

\section{Technical instructions}

\section{The article structure:}

TITLE of article: English, Romanian, Russian

THE DATA ON AUTHOR/AUTHORS: Name Surname, scientific degree, scientific title, institution (without abbreviations), in: English, Romanian and Russian with a footnote at the first page of the article: (CName Surname (author), e-mail.

THE ABSTRACT will contain actuality, aim of the research, main methods of researching, and the most relevant obtained results from the research in English, Romanian and Russian.

KEYWORDS: 6-8 keywords in English, Romanian and Russian.

JEL Classification (Journal of Economic Literature Classification System:

https://www.aeaweb.org/econlit/jelCodes.php) 
1. INTRODUCTION (the argumentation of the actuality of the research/the discussed topic)

2. LITERATURE REVIEW. The degree of scientifically approach and its presentation in the scientific literature

3. DATA SOURCES AND USED METHODS

4. The results of own research and discussions

5. CONCLUSIONS

6. REFERENCES: up to 30 sources

7. Presentation date

\section{Typing rules}

- The form of basic text: A4 (edges: 20x20x20x20 mm); Times New Roman; 12pt; line spacing $-1,5$, left-right alignment, the paragraph $10 \mathrm{~mm}$

- The article title (centered, in capitals, 12pt.)

- The author of the article (right alignment, bold, italic), the last name of the author with capitals, $12 \mathrm{pt}$.

- The abstract (left-right alignment, italic, paragraph $10 \mathrm{~mm}, 12 \mathrm{pt}$. (250 words)

- Keywords (left-right alignment, italic, paragraph $10 \mathrm{~mm}, 12 \mathrm{pt}$.

- JEL Classification (right alignment, bold, italic, 12pt.)

- The work will contain 10-15 pages (from 25 to 40 thousands signs)

- Graphic elements (tables and figures) must be of a high quality (white-black), will be placed, directly, after concerned reference in the text. All the elements, mandatory, shall be accompanied by name and order number (above the table, below the figure), source and, as needed, additional information: note, legend (underneath the element).

- Bibliographic references are placed at the end of the article (Name, surname initial, title, editor, year, pages, ISSN). In the text shall be indicated bibliographical references, according to the order number of the reference (i.e., [1, p.10]).

Ethic statement

At the first presentation of the article, the author signs, indicates the date and confirms that he was introduced with disclosure requirements of the article to be published and the declaration of responsibility for the authenticity of the material, in addition submits the copyrights to the editor.

Declaration: Hereby, I declare on my own responsibility that the presented scientific work is authentic with no hint of plagiarism, and there is no conflict of interest, I accept the Open Access Policy, and I submit the copyright to the editor.

Date of presentation:___Signature:

Review. All the supplies, submitted for publication in „Economy and Sociology” journal, are subject to the review „double-blind review system” by Editorial board.

Editorial college of the „Economy and Sociology” Journal 
Bun de tipar: 27.12.2019. Tirajul 100 ex.

Coli editoriale: 12,30. Com. 21.

Complexul Editorial al INCE, 2019

Editor's address:

National Institute of Economic Research

Ion Creanga Street, 45, mun. Chisinau, MD-2064

e-mail: incemd.redactie.es@gmail.com website: https://economy-sociology.ince.md

Tel. + 37322501130 